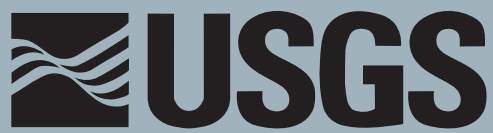

science for a changing world

\title{
Geologic Field-Trip Guide to Lassen Volcanic National Park and Vicinity, California
}

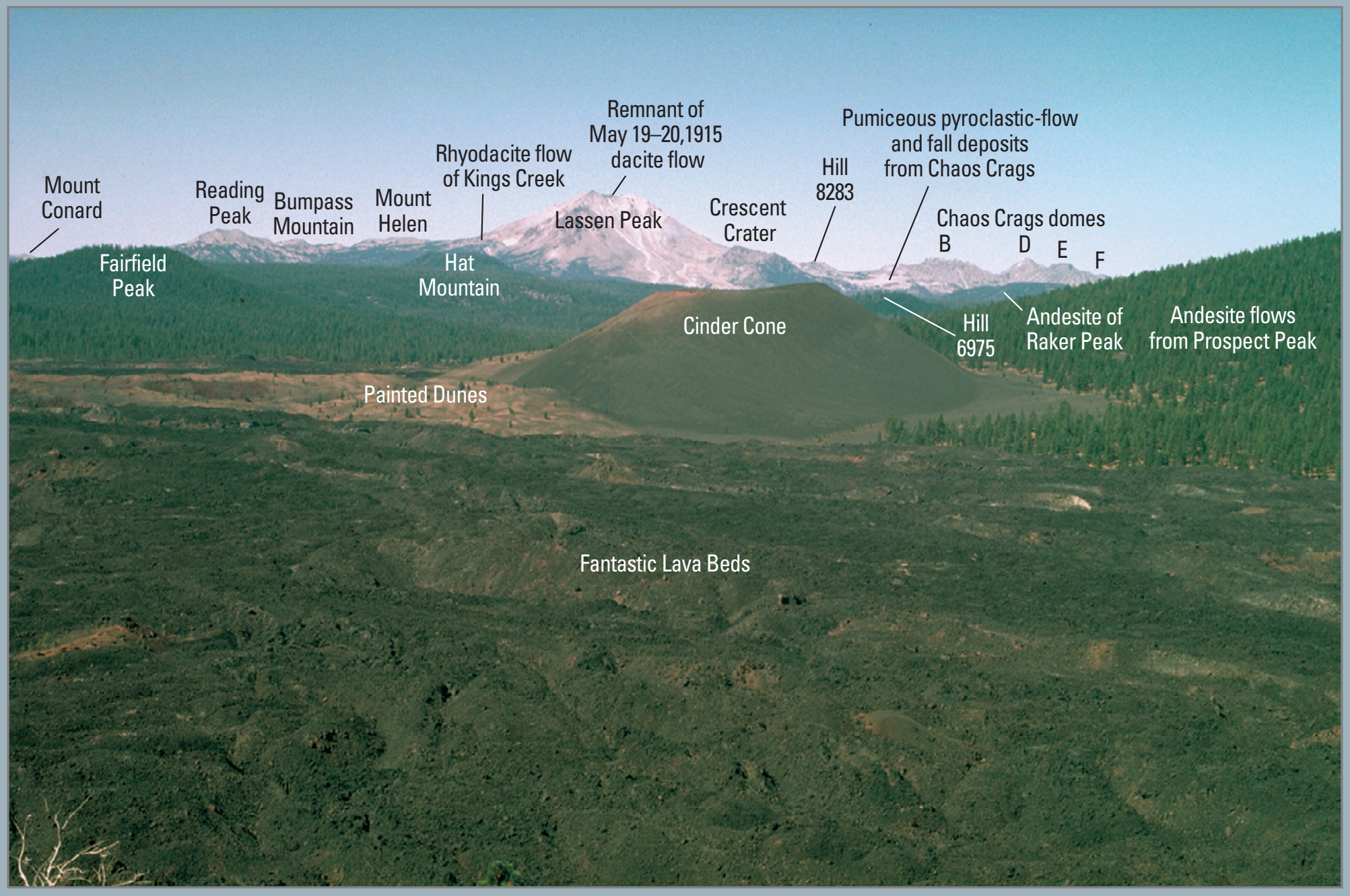

Scientific Investigations Report 2015-5067

U.S. Department of the Interior

U.S. Geological Survey 
COVER

Photograph looking west-southwest from Sunrise Peak (just east of Butte Lake) towards the Lassen domefield (the youngest part of the Lassen Volcanic Center). In the foreground are Cinder Cone (1666 C.E.) and its related flows (Painted Dunes and Fantastic Lava Beds). Cinder Cone, Fairfield Peak (82 $\pm 14 \mathrm{ka}$ ), and Hat Mountain ( 50-40 ka) are units in the younger Twin Lakes sequence of the Lassen domefield. Hill 6975 is the vent for the andesite and basaltic andesite of Cluster Lakes (300-250 ka). Both it and the andesite of Raker Peak ( $270 \pm 18 \mathrm{ka}$ ) are units in the older Twin Lakes sequence. Lassen Peak ( $27 \pm 1 \mathrm{ka})$ and Chaos Crags (1,103 \pm 13 B.P.) are domes of the Eagle Peak sequence of the Lassen domefield. Reading Peak (212 \pm 5 ka), Bumpass Mountain ( $232 \pm 8$ ka), Mount Helen $(249 \pm 12$ ka), Crescent Crater $(236 \pm 1 \mathrm{ka})$, and Hill $8283(261 \pm 5 \mathrm{ka})$ are domes of the Bumpass sequence. At the far left, Mount Conard is an erosional remnant of Brokeoff Volcano (590-385 ka), an older part of the Lassen Volcanic Center. Flows from Prospect Peak $(247 \pm 56 \mathrm{ka})$ are not part of the Lassen Volcanic Center, but instead are part of the regional calc-alkaline suite. 


\section{Geologic Field-Trip Guide to Lassen Volcanic National Park and Vicinity, California}

By L.J. Patrick Muffler and Michael A. Clynne

Scientific Investigations Report 2015-5067 


\title{
U.S. Department of the Interior SALLY JEWELL, Secretary
}

\section{U.S. Geological Survey \\ Suzette M. Kimball, Acting Director}

\author{
U.S. Geological Survey, Reston, Virginia: 2015
}

For more information on the USGS - the Federal source for science about the Earth, its natural and living resources, natural hazards, and the environment—visit http://www.usgs.gov or call 1-888-ASK-USGS.

For an overview of USGS information products, including maps, imagery, and publications, visit http://www.usgs.gov/pubprod/.

Any use of trade, firm, or product names is for descriptive purposes only and does not imply endorsement by the U.S. Government.

Although this information product, for the most part, is in the public domain, it also may contain copyrighted materials as noted in the text. Permission to reproduce copyrighted items must be secured from the copyright owner.

Suggested citation:

Muffler, L.J.P., and Clynne, M.A., 2015, Geologic field-trip guide to Lassen Volcanic National Park and vicinity, California: U.S. Geological Survey Scientific Investigations Report 2015-5067, 67 p., http://dx.doi.org/10.3133/ sir20155067. 


\section{Acknowledgments}

Our work in the Lassen region builds on that of previous geologists and would have been considerably more difficult without the context they provided. The mapping and publications of Howel Williams were, by far, the most insightful in this regard. His "Geology of the Lassen Volcanic National Park, California" (Williams, 1932) stands as a classic work in interpretation of the geologic history of the Lassen area and the Cascade Range.

A project of the scope and size of our Lassen investigations could not possibly be completed without the assistance and consultation of colleagues. We particularly acknowledge the significant collaborations of Robert Christiansen and Marianne Guffanti. We were ably assisted over the course of geologic mapping by a number of geologists, primarily Lars Borg, Marianne Guffanti, Gordon Keating (deceased), Deborah Trimble, Jacob Madden, Charles Melancon, and Miranda Fram. We are also grateful to Tracey Felger, Joel Robinson, David Ramsey, Dillon Dutton, Ellen Lougee, and Peggy Bruggman for providing assistance, instruction, and collaboration with GIS compilation.

Geochronologic data are essential to the satisfactory completion of any modern geologic map in volcanic terrain. The volcanic stratigraphy presented herein reflects the major contributions of Brent Dalrymple, Marvin Lanphere, Brent Turrin, Deborah Trimble, Andrew Calvert, and Paul Renne, each of whom contributed age dates on a variety of materials. Potassium-argon (K-Ar) and argon-argon $\left({ }^{40} \mathrm{Ar} /{ }^{39} \mathrm{Ar}\right)$ ages given in the text and figure captions of this guide can be found in Clynne and Muffler (2010) unless otherwise noted. Paleomagnetic data and correlations contributed by Duane Champion played a significant role in refining volcanic stratigraphy in some areas.

Reviews of the manuscript by Russell Evarts, Richard Conrey, and Stephen Self improved both the content and presentation of this guide. The guide also benefited greatly from the careful and constructive editing provided by Peter Stauffer and Claire Landowski. 


\section{Contents}

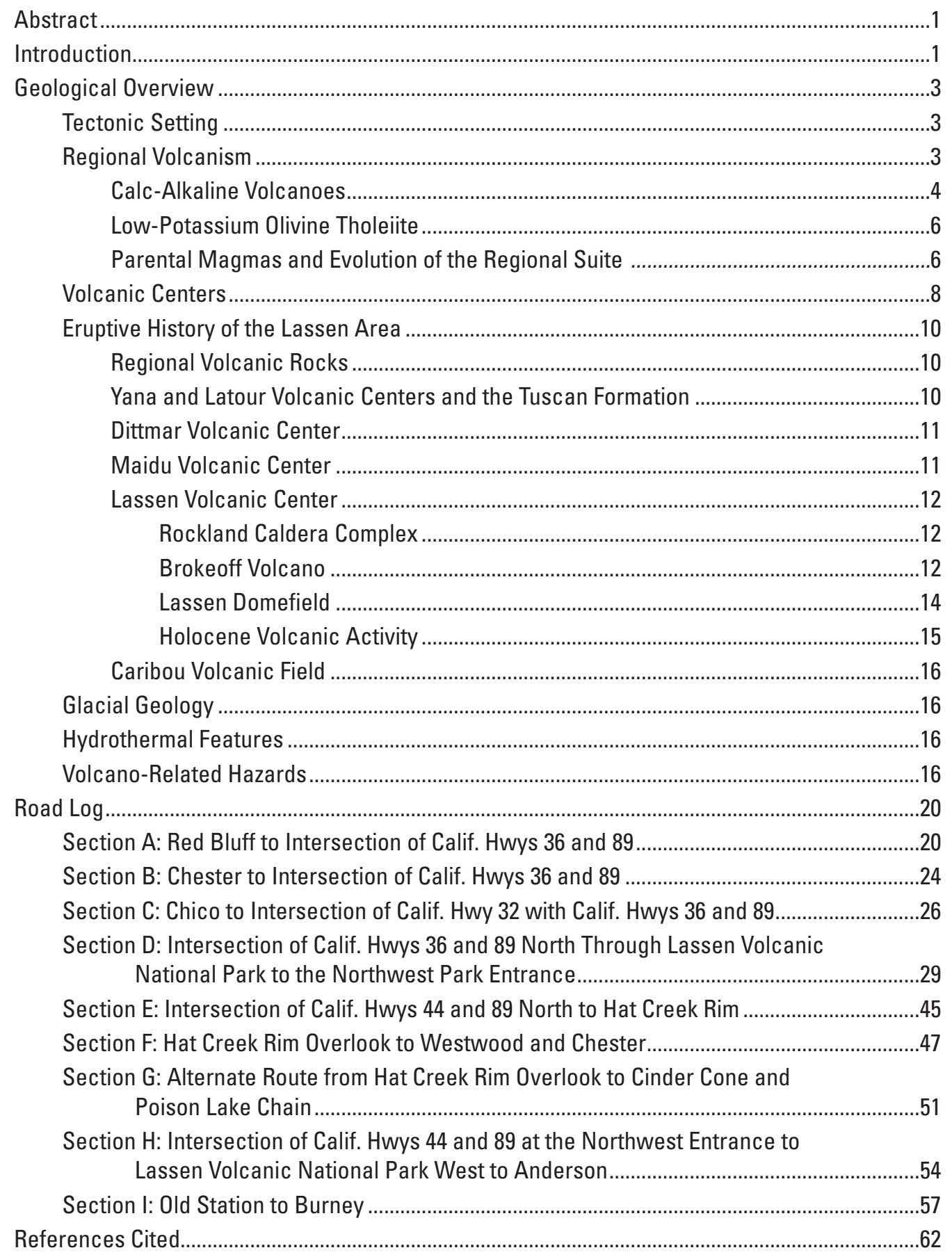




\section{Figures}

1. Index map of Lassen Volcanic National Park and surrounding region......................................2

2. Map showing regional tectonic setting of area from Sacramento Valley to CaliforniaNevada border, including Lassen Volcanic National Park and vicinity, California............4

3. Map of Lassen Volcanic National Park and vicinity emphasizing calc-alkaline and tholeiitic volcanic rocks that surround the Lassen Volcanic Center

4. Graph of $\mathrm{K}_{2} \mathrm{O}$ content against $\mathrm{SiO}_{2}$ content of regional volcanic rocks in the Lassen area.....7

5. Multielement spider diagram showing concentrations of trace elements in primitive basalts of the Lassen region .........................................................................................

6. Diagrammatic cross-section showing magmagenesis model for the Lassen region ......................8

7. Map and chronostratigraphic chart of volcanic centers in the Lassen region.......................9

8. Generalized geologic map and chronostratigraphic chart of Lassen Volcanic National Park and vicinity, California, emphasizing the location, extent, and stratigraphy of the Lassen Volcanic Center.

9. Graph of $\mathrm{SiO}_{2}$ content versus $\mathrm{K}_{2} \mathrm{O}$ content for 250 analyses of volcanic rocks from the Lassen Volcanic Center grouped by eruptive sequence..........................................14

10. Generalized geologic map of eastern part of Lassen Volcanic National Park and adjacent areas, emphasizing the location and extent of volcanic sequences and chains in the Caribou Volcanic Field

11. Chart showing correlation of glacial terminology, ages, and depiction of glacial deposits in the Lassen area by various authors

12. Diagrammatic cross sections of the Lassen hydrothermal system........................................19

13. Map showing thermal areas in and adjacent to Lassen Volcanic National Park ...................20

14. Photograph looking along Calif. Hwy 36 between Red Bluff and Dales, showing features along the Battle Creek Fault scarp and the Cascade Range north of the Lassen Volcanic Center....

15. Photograph looking along Calif. Hwy 36 between Red Bluff and Dales showing volcanic features of the southern Cascade Range.......

16. Panoramic photograph of volcanic features of the Lassen region on Calif. Hwy 36 northeast of the turnoff to Paynes Creek.

17. Panoramic photograph looking west down Deer Creek ......................................................27

18. Panoramic photograph looking northeast up Deer Creek .................................................28

19. Photograph looking west at andesite flow exposed in the face of Bluff Falls quarry ............. 29

20. Photograph showing landslides in hydrothermally altered volcanic rocks ...........................30

21. Annotated photograph showing changes of hydrothermal features at Sulphur Works ........31

22. Photograph taken in November 2011 of mudpot north of Calif. Hwy 89 at Sulphur Works....31

23. Photograph of Brokeoff Mountain looking west from turnout on Calif. Hwy 89 ......................32

24. Photograph of the May 22, 1915, crater at the summit of Lassen Peak ..................................35

25. Photograph of the northeast flank of Lassen Peak taken in June 1913, before the 1914-1917 eruption 
26. Photograph of the Devastated Area taken on the morning of May 22, 1915, before the Plinian eruption of $~ 4: 00$ pm on May 22, 1915

27. Photograph showing the Devastated Area after the eruption of May 22, 1915.

28. Chart giving a summary of events in the 1914-1917 eruptions of Lassen Peak.

29. Generalized geologic map of deposits from the May 1915 eruptions at the summit of Lassen Peak

30. Low-angle oblique aerial photograph looking southwest at Lassen Peak and the proximal Devastated Area..

31. Telephoto view northeast from summit of Brokeoff Mountain looking at Lassen Peak and the west lobe of the dacite flow of May 19-20, 1915.

32. Photographs of hand specimens of four rock types of very different appearance that were produced over a week-long period during the May 1915 eruption from the summit of Lassen Peak.

33. Chart giving a summary of events in the formation of Chaos Crags......................................42

34. Photograph of Chaos Crags and Chaos Jumbles looking southeast from Calif. Hwy 89 .......44

35. Graph of $\mathrm{SiO}_{2}$ content versus $\mathrm{K}_{2} \mathrm{O}$ content for the quenched mafic inclusions and host rocks in Chaos Crags..

36. Photograph of quenched mafic inclusion in dacite/rhyodacite of Chaos Crags.

37. Panoramic photograph looking southwest to northwest from Parhams Point across the Hat Creek Graben and the Hat Creek Basalt towards the crest of the Cascade Range north of Lassen Volcanic National Park.

38. Photograph looking southwest across Silver Lake, illustrating the glaciated physiography of the southern part of the Caribou Volcanic Field.

39. Graph showing variation of $\mathrm{SiO}_{2}$ versus height in a composite ash section at Cinder Cone

40. Harker diagram showing variation of $\mathrm{TiO}_{2}$ versus $\mathrm{SiO}_{2}$ for the array of compositions at Cinder Cone.

41. Photograph of roadcut exposing complex volcanic stratigraphy west of Manzanita Lake

42. Generalized geologic map of the Hat Creek Basalt.................................................................58

43. Oblique satellite image of the northern part of the Hat Creek Fault .......................................59

44. Annotated photograph looking south along the Active Scarp of the Hat Creek Fault............60

45. Photograph looking north across Calif. Hwy 299 northeast of Johnson Park. 


\title{
Geologic Field-Trip Guide to Lassen Volcanic National Park and Vicinity, California
}

\author{
By L.J. Patrick Muffler and Michael A. Clynne
}

\section{Abstract}

This field-trip guide provides an overview of Quaternary volcanism in and around Lassen Volcanic National Park in northern California. The guide begins with a comprehensive overview of the geologic framework and the stratigraphic terminology of the Lassen region, based primarily on the "Geologic map of Lassen Volcanic National Park and vicinity” (Clynne and Muffler, 2010). The geologic overview is then followed by detailed road logs describing the volcanic features that can readily be seen in the park and its periphery. Twenty-one designated stops provide detailed explanations of important volcanic features. The guide also includes mileage logs along the highways leading into the park from the major nearby communities. The field-trip guide is intended to be a flexible document that can be adapted to the needs of a visitor approaching the park from any direction.

\section{Introduction}

This field-trip guide provides an overview of Quaternary volcanism in and around Lassen Volcanic National Park, California, emphasizing the stratigraphy of the Lassen Volcanic Center. Additional stops focus on the 1915 eruption at Lassen Peak, the Lassen geothermal system, and regional tectonism and volcanism. This guide builds on two previous guides: one written for the 1989 meeting of the International Geological Congress in San Francisco, California, and one written for the International Association of Volcanology and Chemistry of the Earth's Interior in Santa Fe, New Mexico (Clynne and Muffler, 1989). A revision of the latter guide was prepared in 2000 for the Workshop on Volcanism in National Parks held by the U.S. Geological Survey (USGS) and the National Park Service in Redding, California, and in Lassen Volcanic National Park (Clynne and others, 2000c). The present guide expands and updates the previous guides, drawing heavily on the introductory text for the "Geologic map of Lassen Volcanic National Park and vicinity" (Clynne and Muffler, 2010). The trip is designed to be self-guided and focuses on geologic features and stratigraphy that can be seen easily from the road network through and surrounding Lassen Volcanic National Park. Discussions of geochemistry and petrology are limited to generalities; users who desire more comprehensive information on these subjects should consult the works in the reference list provided.
The field-trip guide is designed to be supplemented by four USGS Fact Sheets that present more detailed information about aspects of young volcanism and active hydrothermal features of Lassen Volcanic National Park (LVNP):

1. Fact Sheet 022-00: "Volcano hazards of the Lassen Volcanic National Park area, California" (Clynne and others, 2000b; http://pubs.usgs.gov/fs/2000/fs022-00/)

2. Fact Sheet 2014-3119: “A sight 'fearfully grand'-Eruptions of Lassen Peak, California, 1914 to 1917" (Clynne and others, 2014; http://pubs.usgs.gov/fs/2014/3119/)

3. Fact Sheet 023-00: "How old is 'Cinder Cone'?- -Solving a mystery in Lassen Volcanic National Park, California" (Clynne and others, 2000a; http://pubs.usgs.gov/fs/2000/ fs023-00/).

4. Fact Sheet 101-02: "Hot water in Lassen Volcanic National Park — Fumaroles, steaming ground and boiling mudpots" (Clynne and others, 2003; http://pubs.usgs.gov/ fs/2002/fs101-02/).

Another useful supplement to this field-trip guidebook is the set of 48 annotated photographs in the CD-ROM (Muffler and others, 2010) accompanying the geologic map of Clynne and Muffler (2010). To access the photos from the CD-ROM, click on "site" and then the photos folder. The annotated photos also are at http://pubs.usgs.gov/sim/2899/database.html (click on "photographs").

The core of the road $\log$ (Section D) traverses LVNP northward on Calif. Hwy 89 to its intersection with Calif. Hwy 44 near Manzanita Lake (fig. 1). It can be completed in one day. Three introductory sections guide one to the beginning of Section D from different starting points: Section A from Red Bluff, Section B from Chester, and Section C from Chico. Section $\mathbf{E}$ guides one from the end of Section D north to the Hat Creek Rim. Section $\mathbf{F}$ guides one from the Hat Creek Rim clockwise around the Park to Westwood and Chester. Section $\mathbf{G}$ is an alternate loop on unpaved roads from the Hat Creek Rim to the trail that leads to Cinder Cone. Section $\mathbf{H}$ guides one from the end of Section $\mathrm{D}$ west to Shingletown and Anderson. Section I guides one from Old Station north to Burney. To follow all these sections would take three days, particularly if one walks to Bumpass Hell, Lassen Peak, and Cinder Cone. The road logs are thus designed to allow the visitor to pick and choose according to his or her interests, direction of approach to LVNP, or available time. 
Lassen Volcanic National Park comprises $430 \mathrm{~km}^{2}$ of scenic volcanic features, glacially sculpted terrain, and the most spectacular array of thermal features in the Cascade Range. Interest in preserving the scenic wonders of the Lassen area arose in the early 1900s and led to the establishment in 1907 of two small National Monuments centered on Lassen Peak and Cinder Cone (Strong, 1989). The eruptions of Lassen Peak in 1914-15 were the first in the Cascade Range since widespread European settling of the American West in the late 1800s. Through the print media, the eruptions aroused considerable public interest and inspired renewed efforts to establish a National Park. In 1916, Lassen Volcanic National Park was established by combining the previously established National Monuments with adjacent Federal lands.

The southernmost Cascade Range is bounded on the west by the Sacramento Valley and the Klamath Mountains, on the south by the Sierra Nevada, and on the east by the Basin and Range. The Lassen region, which comprises much of the Lake Almanor and Burney 1:100,000 topographic maps, is underlain by volcanic rocks ranging in age from 3.5 million years $(\mathrm{Ma})$ to 100 years. A profound unconformity separates these late
Cenozoic volcanic rocks from underlying sedimentary rocks of Cretaceous age and metamorphic and igneous rocks of Paleozoic and Mesozoic age. These much older rocks are exposed only along Section C of the field-trip guide, but they crop out in the mountains south and southeast of Lake Almanor, in the canyons of Mill Creek and Deer Creek 20 miles south-southwest of LVNP, and in the area of Montgomery Creek $~ 16$ miles northwest of LVNP.

Diller (1895) recognized the young volcanic geology of the region and made the first geologic map of the Lassen area. A 1:48,000-scale map of LVNP produced in one remarkable field season by Williams (1932) was extended by later geologic mapping, notably by Wilson (1961) and by Macdonald (1963, $1964,1965)$. Investigations by the USGS over the past 38 years have led to a detailed 1:24,000 "Geologic map of Lassen Peak and Chaos Crags" (Christiansen and others, 2002) and a 1:50,000 "Geologic map of Lassen Volcanic National Park and vicinity" (Clynne and Muffler, 2010). The latter map is accompanied by a CD-ROM (Muffler and others, 2010) that contains ArcGIScompatible data files used to create the 1:50,000-scale geologic map, both geologic and topographic data and their associated

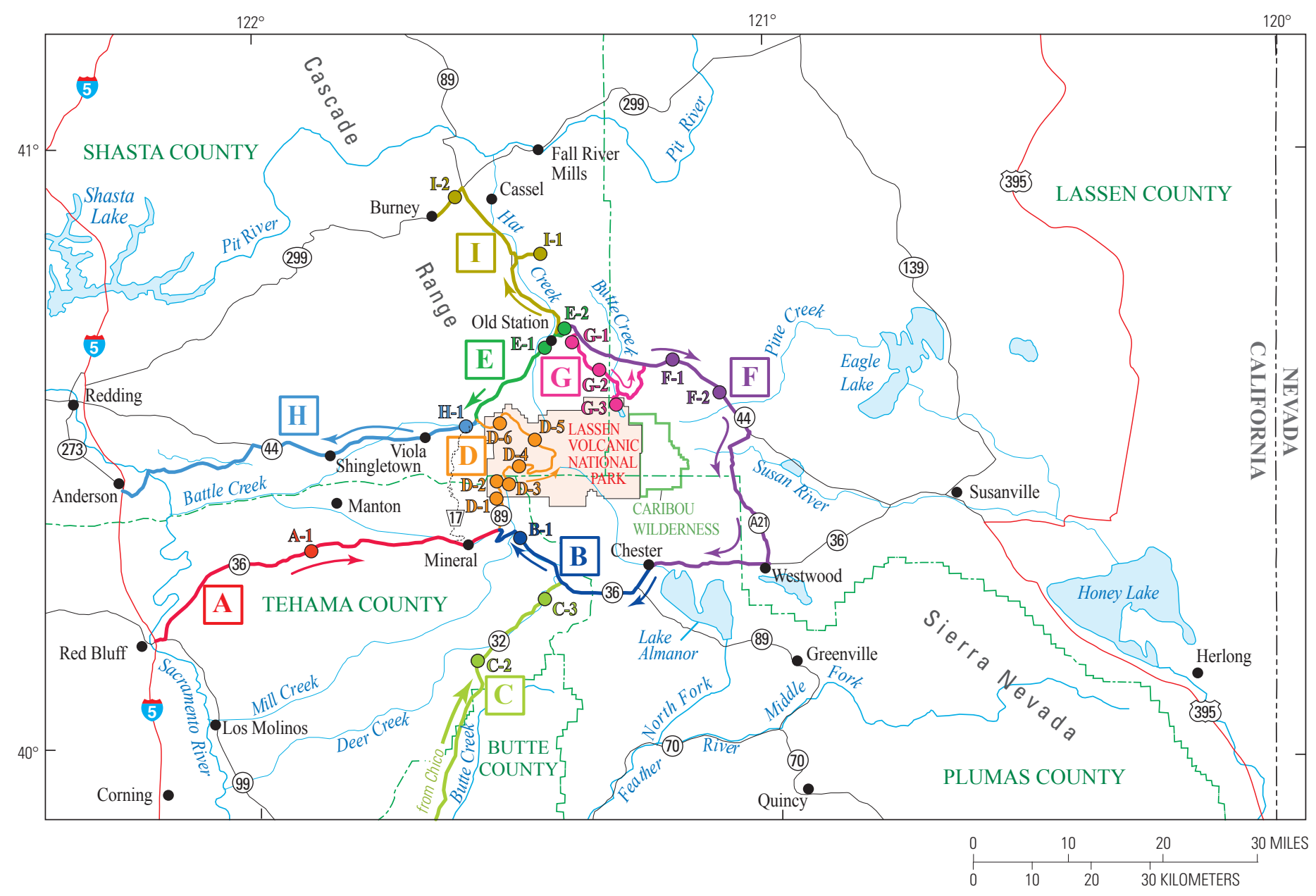

Figure 1. Index map of Lassen Volcanic National Park and surrounding region. Field-trip routes are shown in heavy colored lines. Stops are shown by colored circles. Letters in boxes refer to sections of the road log (see text). Stop C-1 is $\sim 10$ miles south of map boundary, 7.6 miles north of Chico. 
metadata files, printable versions of the geologic map and pamphlet as PDF formatted files, and 1:24,000-scale geologic maps of individual quadrangles used to compile the 1:50,000 map. It also contains ancillary data that support the map, including locations of rock samples selected for chemical analysis and radiometric dating, links to related data or Web sites, and 48 annotated photographs of geologic features. Data contained in the CD-ROM are also available at http://pubs.usgs. gov/sim/2899/. Chemical analyses and locations of samples are given in Clynne and others (2008).

A generalized geologic map at 1:100,000 scale of the Lake Almanor sheet, which includes the southern two-thirds of the Lassen 1:50,000 map, is in preparation by Clynne and Muffler and serves as the source of many of the geological descriptions outside the boundaries of the 1:50,000-scale "Geologic map of Lassen Volcanic National Park and vicinity" (Clynne and Muffler, 2010, http://pubs.usgs.gov/sim/2899/).

A thoughtful discussion and overview of the entire Cascade magmatic arc was presented by Hildreth (2007).

\section{Geological Overview}

\section{Tectonic Setting}

Figure 2 (from Clynne and Muffler, 2010) illustrates the tectonic setting of the Lassen segment (Guffanti and Weaver, 1988) of the Cascade volcanic arc. Volcanism in the Lassen segment is a result of oblique subduction of the oceanic Juan de Fuca Plate eastward beneath the continental North American Plate. From 12 million years ago (12 Ma) to the present, the axis of the Lassen segment migrated westward from the California-Nevada border to its present position (Guffanti and others, 1990). Simultaneously, the width of the arc narrowed, probably because of slab steepening. The southern terminus of active volcanism retreated roughly parallel to the northward extension of the San Andreas Fault System and migration of the Mendocino Triple Junction off the northern California coast. At $12 \mathrm{Ma}$, the southern limit of Cascade volcanism was in the Sierran block south of Lake Tahoe, 110 miles (180 km) southeast of the Lassen area (Busby and others, 2008; Busby, 2013). At $3 \mathrm{Ma}$, the southern limit of active volcanism was in the area of the Yana Volcanic Center, 18 miles $(30 \mathrm{~km})$ south of Lassen Peak. At present, the southern limit of active volcanism approximately corresponds to the south boundary of LVNP, and the youngest dated regional volcano in the area is Sifford Mountain (fig. 3) at about $170 \mathrm{ka}$. These relations suggest a long-term northerly migration rate for the southern terminus of Cascade Arc volcanism of 15 to $20 \mathrm{~km}$ per million years (m.y.; 1.5 to $2 \mathrm{~cm}$ per yr) and a rate for at least the past $3 \mathrm{~m} . \mathrm{y}$. of about $10 \mathrm{~km}$ per m.y. ( $1 \mathrm{~cm}$ per yr). Detailed calculations of the extrusion rate for the Lassen segment of the arc have not been made, but the available data (Sherrod and Smith, 1990) suggest that the extrusion rate was significantly higher at 3-2 Ma than from $2 \mathrm{Ma}$ to the present.
Two independent tectonic regimes affect the Cascade volcanic arc in the Lassen area: the Basin and Range Province and the Walker Lane. The extensional Basin and Range Province is expanding westward into the Cascade Arc (Guffanti and others, 1990), and the active Hat Creek Graben and Lake Almanor Graben are the westernmost major Basin and Range structures in the area (fig. 2). This impingement is manifested in numerous normal faults, many of which provide pathways for magma to reach the surface. Some magmas traverse the crust rapidly, and relatively primitive mafic lavas are widespread, albeit not abundant (Borg and others, 1997). Many regional volcanoes are aligned along fault traces and partially to completely bury them. The Lassen area also sits on the northwest projection of the Walker Lane, a broad linear zone of distributed strikeslip faulting, parallel to and inboard of the San Andreas Fault System, that accommodates about 20 percent of the relative motion between the North American and Pacific Plates (Unruh, 1995; Blakely and others, 1997). This regime generally manifests itself as a small strike-slip component on the dominantly normal faults. Although the Hat Creek Graben-Lake Almanor Graben structure crosses the eastern half of LVNP (Clynne and Muffler, 2010), few faults are mapped there. Expression of the grabens is obscured by a combination of young volcanism and glaciation, and additional faults are likely to be concealed in the subsurface.

\section{Regional Volcanism}

On a regional scale, Quaternary volcanism in the southernmost Cascade Range has built a broad platform of overlapping and intercalated mafic to intermediate volcanoes. This platform comprises hundreds of coalescing small- to medium-size volcanoes (as large as a few $\mathrm{km}^{3}$ ) consisting predominantly of basalt, basaltic andesite, and andesite. We refer to these as regional volcanoes and (or) regional lavas. A seismic-refraction experiment (Berge and Stauber, 1987) indicates that the young volcanic platform is $\sim 4 \mathrm{~km}$ thick in the active southernmost Cascade Arc.

Two distinct parental magmas and their derivatives contribute to the suite of regional lavas in the Lassen area: calc-alkaline basalt and low-potassium olivine tholeiite basalt (fig. 3; Borg, 1995; Borg and others, 1997; Clynne and Borg, 1997; Borg and others, 2002). Edifices containing both magma types are rare. Calc-alkaline compositions are related to Cascade Arc magmatism and dominate the regional suite in both volume and abundance. Small calc-alkaline volcanoes are scoria cones with fields of lava flows, whereas large calc-alkaline volcanoes are steep-sided cones or shields with gentle slopes. Low-potassium olivine tholeiite (LKOT; sometimes termed high-alumina olivine tholeiite or HAOT) basalt is a volumetrically minor but widespread component of the regional volcanism and is related to Basin and Range extension. LKOT basalt erupts from fissures between the shield volcanoes, and the fluid lavas flood intervening valleys. 


\section{Calc-Alkaline Volcanoes}

Regional calc-alkaline volcanoes have a wide range of sizes and forms. They comprise a continuum from scoria cones (commonly and locally called cinder cones) through steep-sided lava cones to broad shield volcanoes. Typically, lava flows of regional calc-alkaline volcanoes have blocky vesicular lava surfaces, although 'a'ā surfaces are also observed. Interiors have joint patterns that are thickly slabby to thinly platy. Aphanitic textures are typical, and holocrystalline textures are generally confined to thick or ponded flows.

The smallest and most abundant volcanoes are scoria cones, typically 50-200 m in height. Scoria cones are composed of bedded scoria and bombs piled up around a vent. Typically they have an associated lava flow that erupted from the base of the cone. Scoria cones have a single period of activity (that is, they are monogenetic). In this region they typically erupt small-volume, blocky to 'a'ā lava flows. Scoria cones are usually homogeneous in chemical

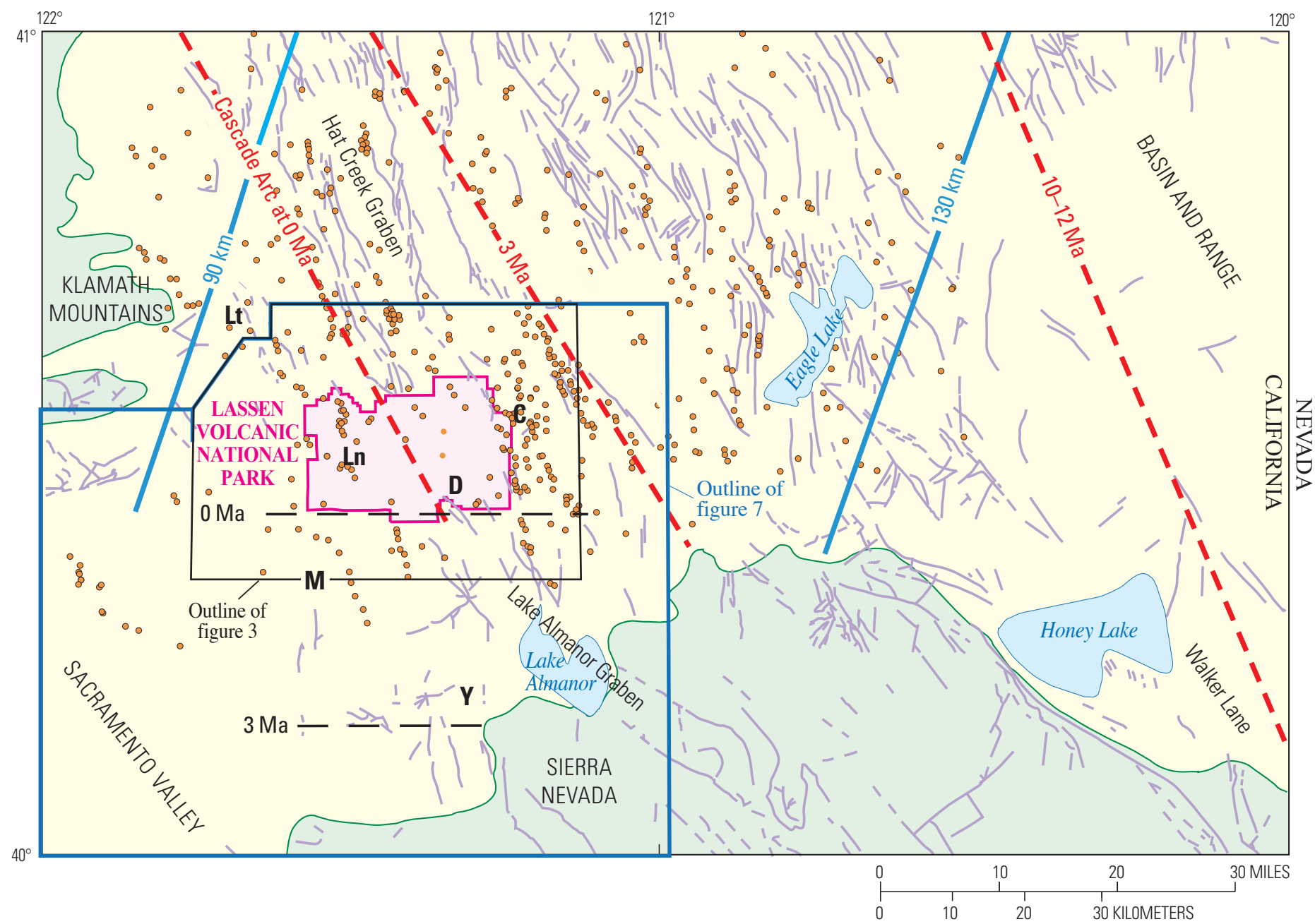

Figure 2. Map showing regional tectonic setting of area from Sacramento Valley to California-Nevada border, including Lassen Volcanic National Park and vicinity, California. Light-yellow background indicates late Tertiary to Holocene volcanic rocks of the Cascade Arc and the Basin and Range. Green background indicates Paleozoic to Mesozoic metamorphic-plutonic basement of the Sierra Nevada and Klamath Provinces (small outliers of volcanic rocks not shown). Orange dots indicate the location of volcanic vents younger than about 7 $\mathrm{Ma}$ (older vents not shown). The large majority of vents are regional calc-alkaline volcanoes. Thin violet lines show the location of faults. Dashed red lines show the approximate position of the arc axis at the times indicated, and dashed black lines indicate the approximate southern terminus of arc volcanism at the times indicated. At $\sim 12 \mathrm{Ma}$, the axis of the Lassen segment of the arc was near the CaliforniaNevada border. Since then, the arc axis has migrated westward to its present position. Simultaneously, the width of the arc narrowed (Guffanti and others, 1990). Thick blue lines indicate the estimated present-day depth to the subducted Gorda Plate. C, Caribou Volcanic Field; D, Dittmar Volcanic Center; Ln, Lassen Volcanic Center; Lt, Latour Volcanic Center; M, Maidu Volcanic Center; Y, Yana Volcanic Center. Map taken from figure 5 of Clynne and Muffler (2010), as updated from Guffanti and others (1990). 


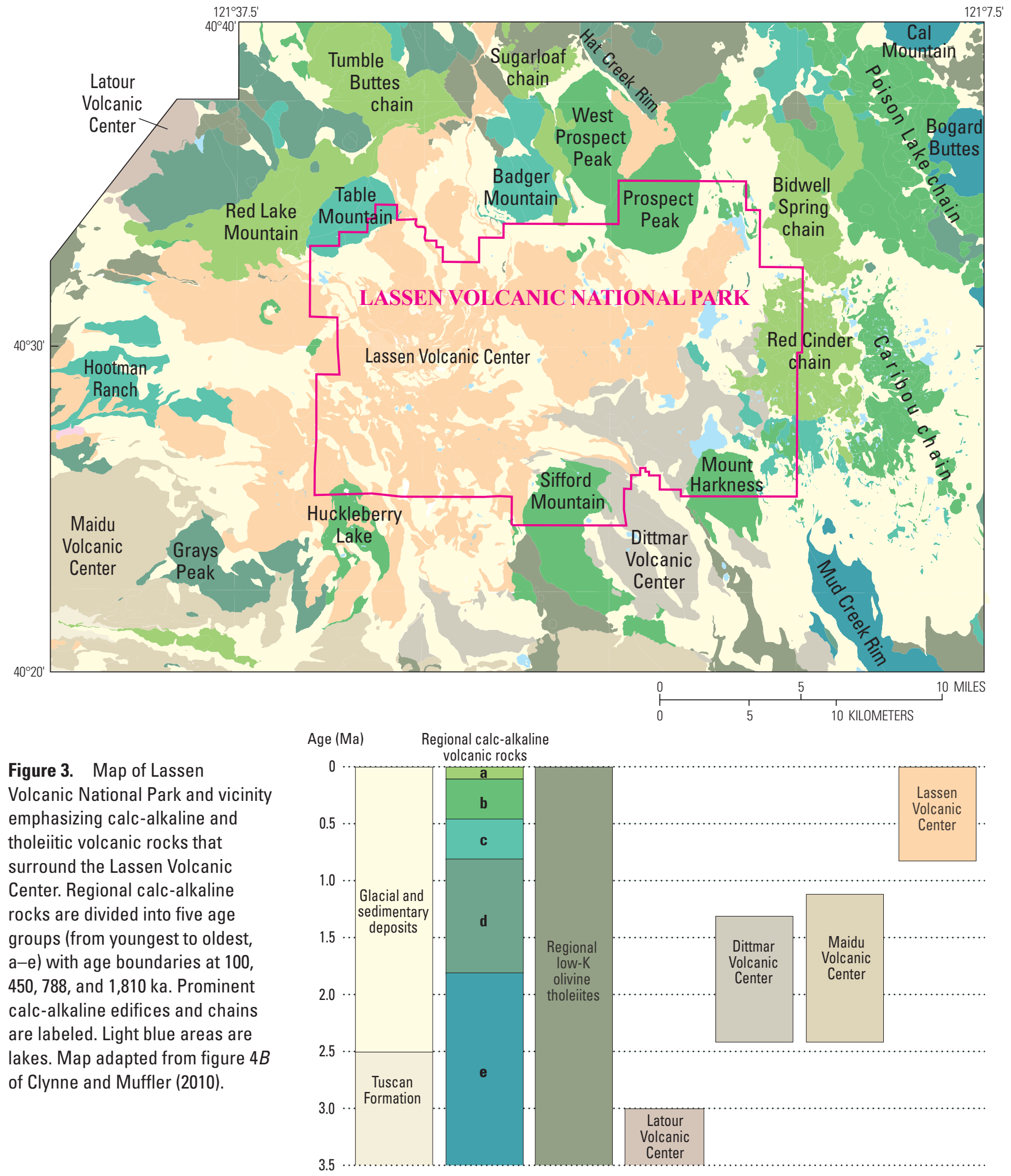


Geologic Field-Trip Guide to Lassen Volcanic National Park and Vicinity, California

composition and mineralogy, and they tend to occur in groups of similar age and lithology.

Lava cones and shield volcanoes are bigger (typically $300-800 \mathrm{~m}$ in height) than scoria cones and are more or less circular in plan view. Lava cones and shield volcanoes are constructed by eruptions from a central vent or flank vents high on the edifice that together build a steep-sided lava cone or a flatter shield volcano. These are commonly capped by a scoria cone, but they generally lack widely distributed fragmental deposits. They have a single period of activity (monogenetic) or a longer period of intermittent activity as long as a few tens of millennia (polygenetic), and they build a variety of edifice sizes as much as a few $\mathrm{km}^{3}$ in volume. Lavas from the longer-lived, larger regional volcanoes (shields or lava cones) have a single chemical composition or display small compositional ranges throughout the lifetime of the edifice. If compositionally heterogeneous, they typically evolve with time to higher silica and crystal contents with accompanying changes in phenocryst assemblage.

The calc-alkaline regional suite is a continuum of olivine basalt, olivine-augite basaltic andesite, and two-pyroxene andesite; rocks more silicic than andesite are rare (fig. 4). Phenocryst assemblages are relatively simple. Primitive basalts contain olivine, commonly without a second phase. Evolved basalts add augite and plagioclase to the assemblage, and most basaltic andesites contain a combination of olivine, augite, and plagioclase phenocrysts. Complex zoning patterns, multiple populations of phenocrysts, and resorption or reaction features in phenocrysts are generally absent in mafic calc-alkaline rocks, but they are present in some andesites. Hypersthene replaces olivine in the fractionating assemblage in the range 56-58 percent $\mathrm{SiO}_{2}$, and most andesites contain both augite and hypersthene. Glomeroporphyritic clots of crystals, generally of the same phases as are present as phenocrysts in the rock, are common in evolved rocks of the calc-alkaline suite.

\section{Low-Potassium Olivine Tholeiite}

LKOT lava flows form widespread sheets that have a characteristic surface morphology. The upper and lower surfaces of flow units contain abundant spherical vesicles, and flow tops are often ropy (pāhoehoe) and have a characteristic joint pattern of crudely hexagonal blocks. Interiors of flow units are generally holocrystalline and often diktytaxitic; the flows are massive with a pattern of widely spaced blocky joints. Upper flow surfaces have little relief except for common to abundant tumuli. These characteristics are rapidly obscured by weathering and soil-forming processes, so that, within about 400-500 k.y., LKOT flows in the Lassen area become flat surfaces with thick soils. Despite being volumetrically subordinate overall to calc-alkaline volcanic products, volumes of individual LKOT flows are relatively large; volumes of as much as a few $\mathrm{km}^{3}$ are typical. LKOT flows were erupted from fissures that built spatter cones and ramparts; scoria cones are rare. These vents are inconspicuous in the geologic record because they are composed of glassy scoria that is easily weathered and eroded, and the low-relief vent profiles are often buried by younger volcanic rocks. Vents for LKOT flows older than a few hundred thousand years are difficult to identify.

The LKOT suite displays remarkable chemical and petrographic homogeneity-almost all analyses contain 48-50 percent $\mathrm{SiO}_{2}$ (fig. 4). LKOT typically contains sparse olivine phenocrysts, accompanied by plagioclase in slightly more evolved examples. Augite phenocrysts and multiple phenocryst populations are rare, as are phenocrysts with strong zoning or resorption textures. Glomeroporphyritic clots of crystals like those found in calc-alkaline rocks are uncommon and generally are confined to near-vent parts of lava flows. Borg and others (2002) summarized the lithologic, petrographic, and distinctive geochemical characteristics of LKOT.

\section{Parental Magmas and Evolution of the Regional Suite}

A diverse array of mafic compositions is found in the Lassen region. These have been extensively studied and modeled, and only a brief summary of magma compositions and sources is given here. For additional discussion see the references cited in Clynne and Muffler (2010).

The most striking feature of LKOT from the Lassen area is the limited range in major- and trace-element contents displayed by these lavas (Clynne, 1993; Bacon and others, 1997; Clynne and others, 2008). Distinctive features of LKOT from the Lassen region are low $\mathrm{SiO}_{2}(\sim 48-50$ weight percent), low alkali content, especially $\mathrm{K}_{2} \mathrm{O}(\sim 0.1-0.4$ weight percent), and low volatile content (Sisson and Layne, 1993). In general, their trace-element characteristics are like those of the mid-ocean ridge basalts that are enriched in light rare-earth elements (E-MORB) (fig. 5). Sr and $\mathrm{Nd}$ and other isotopic systematics of LKOT are distinct from those of calc-alkaline basalts (Bacon and others, 1997; Borg and others, 1997; Borg and others, 2000; Borg and others, 2002).

In contrast to LKOT, the calc-alkaline suite forms a compositional (fig. 4) and isotopic continuum. The calc-alkaline lava suite has geochemical characteristics typical of arc magmas erupted through continental crust, for example, in the Japan and Kamchatka Arcs (Gill, 1981). Geochemical diversity is greatest in the most primitive compositions, and fractionation reduces the range of geochemical diversity in more evolved rocks through interaction with the lower crust and mixing within the suite (Clynne, 1990; Bullen and Clynne, 1990; Hart and others, 2002). Evolution of mafic magmas is dominated by crystal fractionation, but addition of small-degree partial melts of mafic lower crust is also an important process (Clynne, 1993). Assimilation of upper crust also plays a role in determining the geochemical composition of some andesitic regional volcanoes. For the volcanic centers in the Lassen region, calc-alkaline basalt is the parental magma.

The Lassen region contains primitive (unevolved) calc-alkaline basalts and magnesian andesites that display a wide range of compositions with systematic variation across the arc. At one end of the spectrum are low-K (0.3-0.8 weight percent) basalts with low contents of incompatible elements and a strong arc 
Geological Overview

Figure 4. Graph of $\mathrm{K}_{2} \mathrm{O}$ content against $\mathrm{SiO}_{2}$ content of regional volcanic rocks in the Lassen area, showing $\sim 60$ analyses of calc-alkaline rocks and lowpotassium olivine tholeiite (LKOT) basalts less than about 3 million years old. The calc-alkaline rocks are dominantly medium$\mathrm{K}_{2} \mathrm{O}$ as defined by Gill (1981), and most are basalt to andesite; rocks with more than about 63 percent $\mathrm{SiO}_{2}$ are sparse in the regional suite. The LKOT suite is chemically homogeneous at 48-50 percent $\mathrm{SiO}_{2}$.

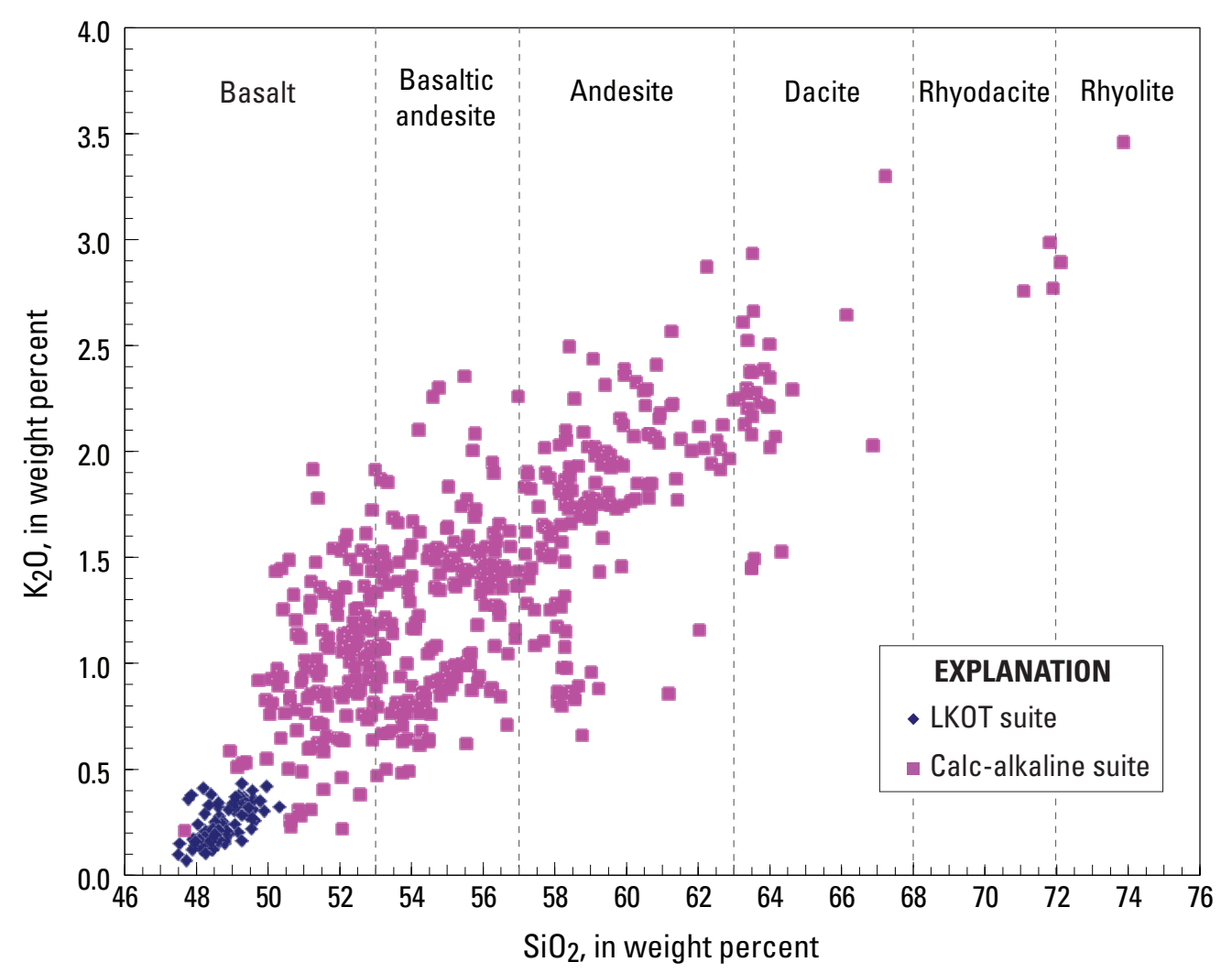

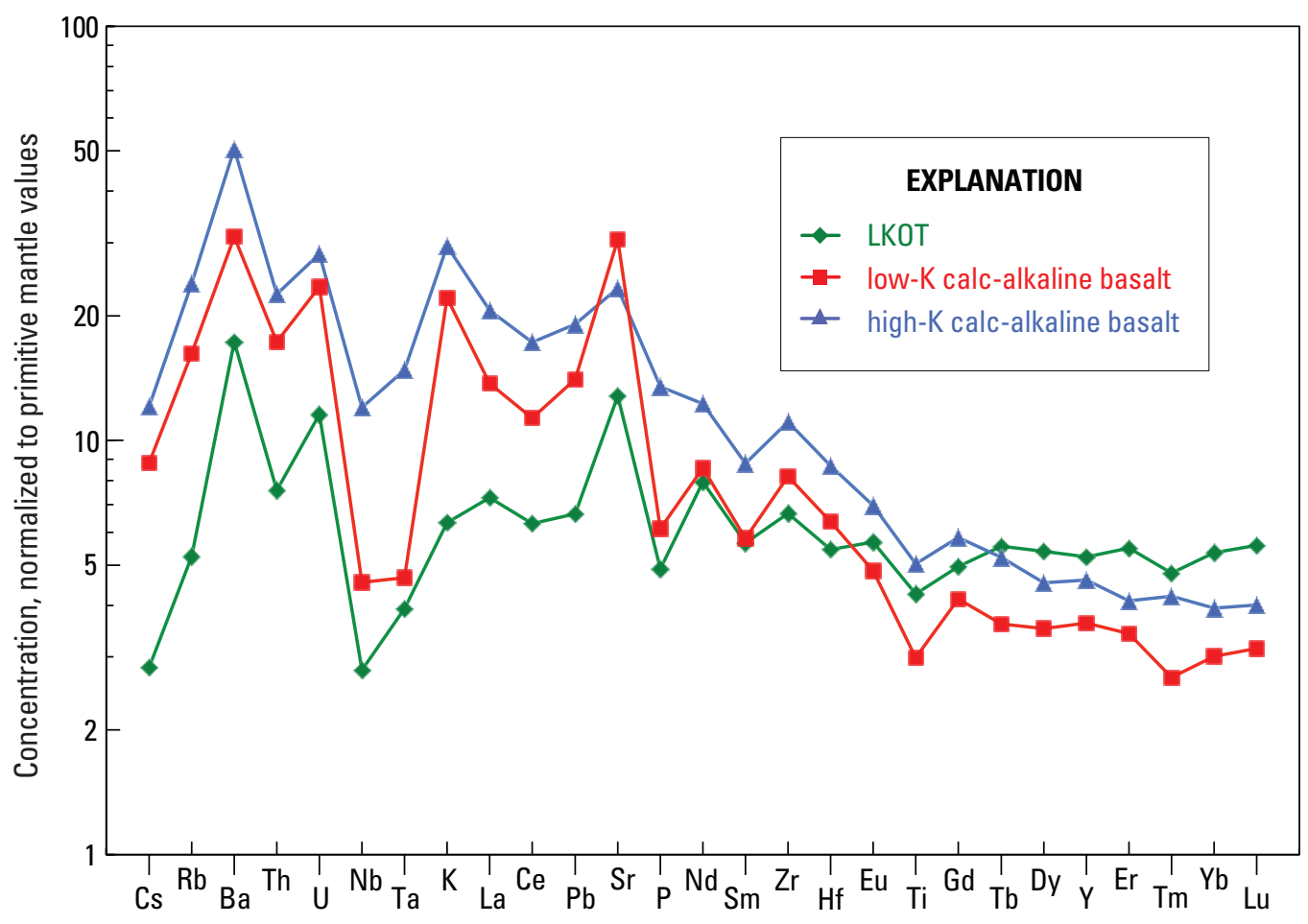

Figure 5. Multielement spider diagram showing concentrations of trace elements in primitive basalts of the Lassen region. Diagram shows the abundances of trace elements in the average compositions that produce the array of primitive basalts in the Lassen region, normalized to primitive mantle values (vertical axis) of Sun and McDonough (1989). Magnesian andesites (not shown) are essentially equivalent to the low- $\mathrm{K}$ calc-alkaline basalts, but have $\mathrm{SiO}_{2}>53$ percent, $\mathrm{Fe} \mathrm{O}^{*} / \mathrm{MgO}<1$, and slightly steeper patterns than low-K calcalkaline basalts. Low-potassium olivine tholeiites (LKOT) have lower overall abundances of incompatible elements, a smaller slab component, and higher concentrations of heavy rare-earth elements (HREE). 
geochemical and MORB-like isotopic signature (Clynne, 1993; Bacon and others, 1997; Borg and others, 1997) that are present in the arc axis. The most extreme of these are the primitive magnesian andesites, present mostly in the forearc. The other end of the spectrum is characterized by high- $\mathrm{K}(0.8-2.0$ weight percent) basalts with higher contents of incompatible elements, a weaker arc geochemical signature, and isotopic compositions similar to ocean-island basalts (Clynne, 1993; Bacon and others, 1997; Borg and others, 1997) that are found mostly in the backarc. The differences in basalt compositions lead to a model for magmagenesis in the Lassen region that explains the mineralogical, compositional, and spatial systematics of the lavas (fig. 6).

\section{Volcanic Centers}

Intercalated within the regional volcanic rocks are a few voluminous (as much as a few hundred $\mathrm{km}^{3}$ ) and long-lived (0.5-1 m.y. or longer) foci of volcanism called volcanic centers. Volcanic centers erupt only calc-alkaline magmas but are compositionally diverse. The fundamental differences between regional calc-alkaline volcanoes and volcanic centers are the latters' longevity, volume, and range of compositions in a single edifice or geographic locale. Five volcanic centers younger than about 3.5 Ma have been recognized along the Cascade axis in the Lassen area (fig. 7). Although each volcanic center experienced a distinct evolution, that evolution generally consisted of an initial phase of silicic volcanism followed by construction of a large composite cone dominated by andesite, which is flanked by a variety of younger, more silicic rocks. Late in the evolution of each volcanic center, an acidic hydrothermal system, driven by heat from cooling subvolcanic silicic magma bodies, caused alteration of the permeable rocks of the composite cone.

Subsequent glacial and fluvial erosion of the altered interiors of the composite cones resulted in bowl-shaped depressions surrounded by more resistant rims of thick, unaltered, flank lava flows. The Yana, Maidu, Dittmar, and Latour Volcanic Centers have reached this stage, and their hydrothermal systems are extinct. The Lassen Volcanic Center (LVC) hosts continuing silicic volcanism and an active hydrothermal system (Muffler and others, 1982; Muffler and others, 1983; Ingebritsen and Sorey, 1985; Clynne and others, 2003; Janik and McLaren, 2010).

Volcanic centers contain a diverse assemblage of rock types from basalt to rhyolite, but they are dominated by andesite and

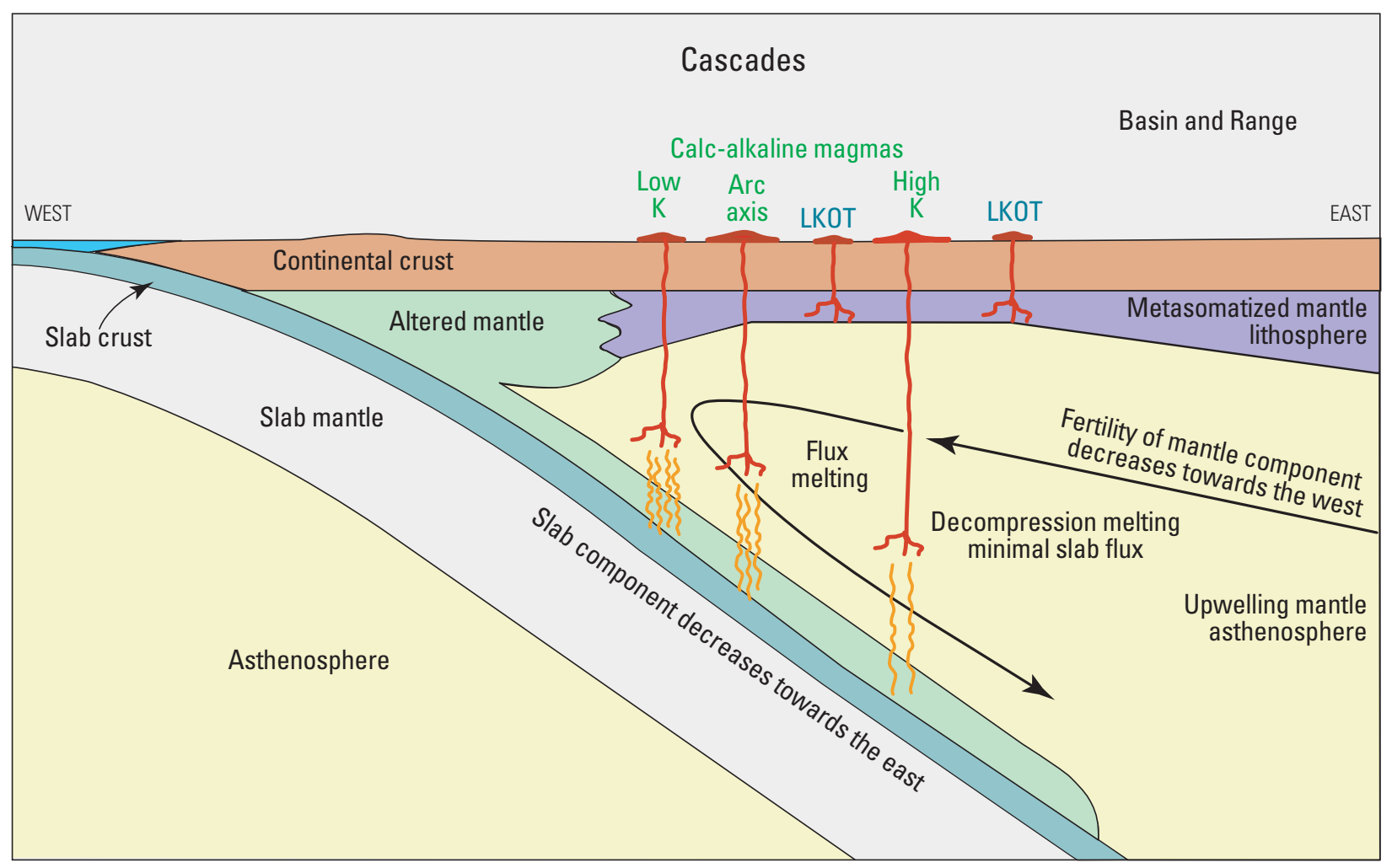

Figure 6. Diagrammatic cross-section showing magmagenesis model for the Lassen region. The arc geochemical signature decreases from west to east across the arc, whereas the fertility of the subarc mantle decreases from east to west. Calc-alkaline arc magmas in the east have a weak slab signature and are generated by decompression melting of relatively fertile Iherzolite. In contrast, calc-alkaline basalt magmas from the arc axis have a stronger slab signature and are generated by flux melting of relatively depleted lherzolite. Calc-alkaline magnesian andesites in the forearc have the strongest slab signature and are generated by flux melting of harzburgite. This model is consistent with mineralogy, major- and trace-element composition, isotope geochemistry, and spatial systematics of magmas in the Lassen area. Note that lowpotassium olivine tholeiite (LKOT) comes from a much shallower depth, probably in the mantle lithosphere, than does the calc-alkaline basalt. 


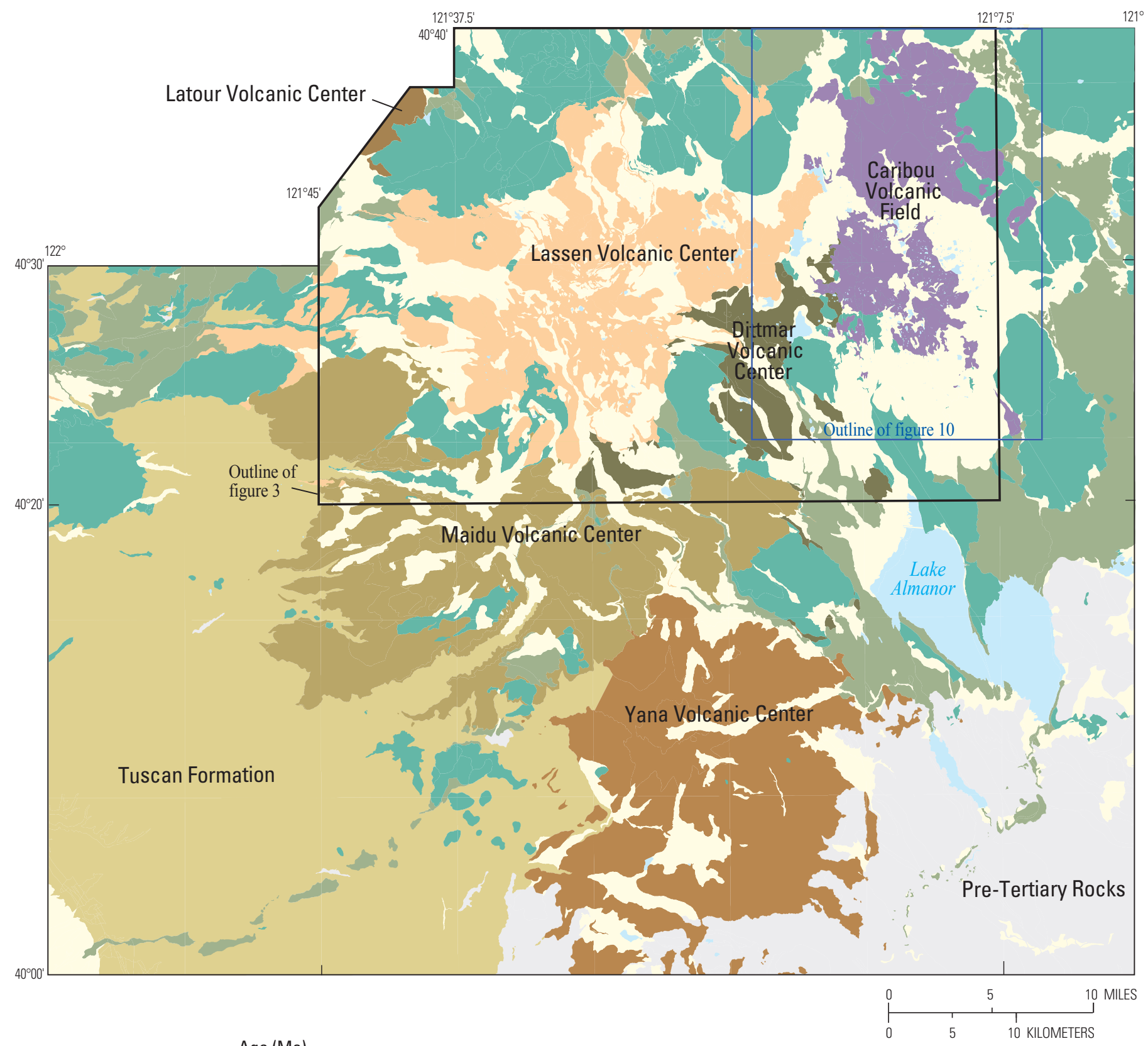

Figure 7. Map and chronostratigraphic chart of volcanic centers in the Lassen region. Generalized regional geologic map emphasizes the location, extent, and ages of large volcanic centers, including those in Lassen Volcanic National Park. Blue areas are lakes. Map adapted from figure $4 A$ of Clynne and Muffler (2010).
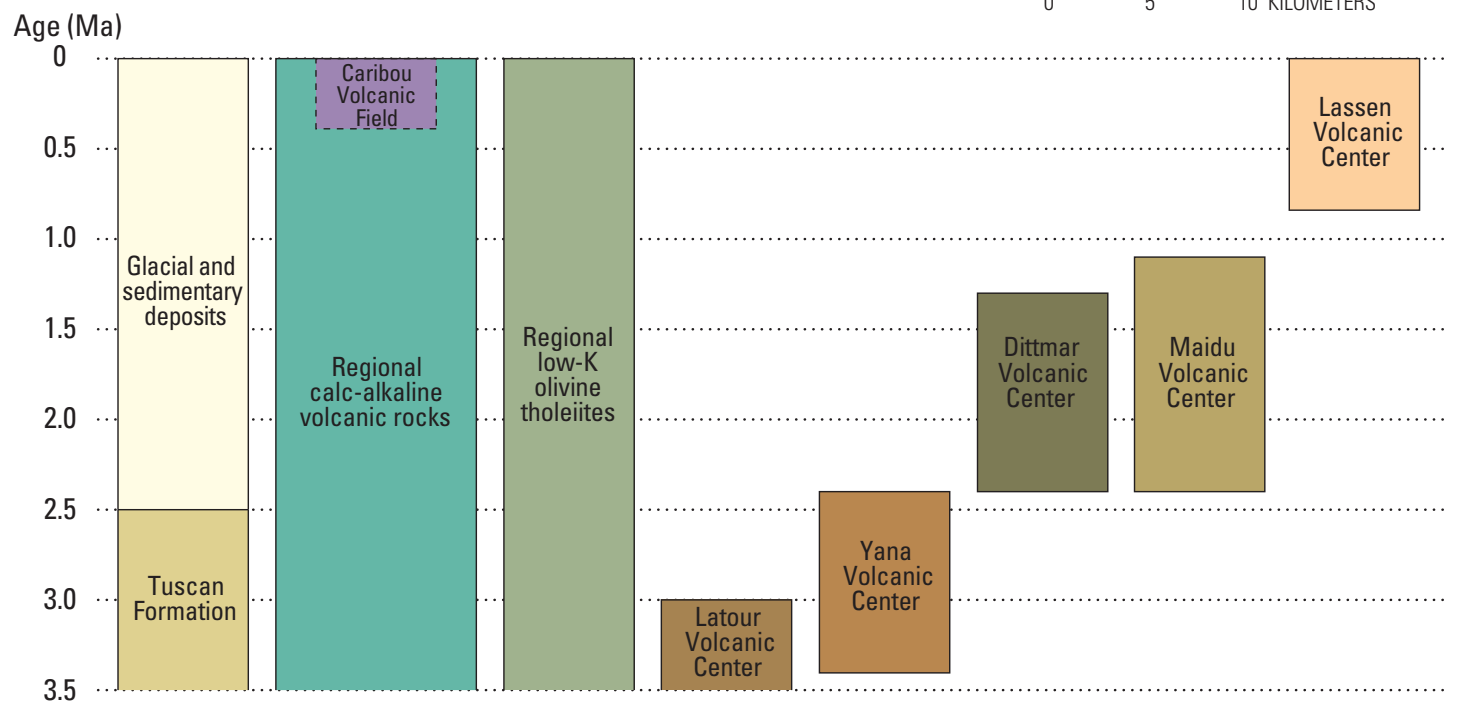
dacite. Andesites in volcanic centers evolve from regional calcalkaline mafic parental compositions by crystal fractionation and addition of a small crustal melt component (Clynne, 1990; Bullen and Clynne, 1990). Petrography of volcanic-center andesites is much more complex than that of rocks from regional volcanoes, and geochemical and petrographic evidence for magma mixing is abundant. Phenocrysts commonly are larger and more abundant than in regional lavas of equivalent silica content. Multiple phenocryst populations, reverse and strong normal zoning, and abrupt changes in phenocryst compositions are typical of volcanic-center rocks. Glomeroporphyritic clots of crystals, interpreted to be derived from bodies of cumulate material fractionated from parental and evolved mafic magmas, are abundant in volcanic-center andesites and attest to efficient recycling of crystals in the magmatic system. Dacites are characterized by very pronounced disequilibrium phenocryst assemblages. Coexisting populations of resorbed and unresorbed phenocrysts and unstable assemblages (for example, magnesian olivine plus quartz) are common, and quenched mafic magmatic inclusions are abundant.

Volcanic centers result from a local increase in the amount of basaltic magma intruded into the crust from the mantle relative to the background calc-alkaline regional volcanism (Guffanti and others, 1996). Increased basaltic intrusion heats the crust and promotes interaction between mafic magma and crustal rocks. A complex, vertically zoned magmatic system with localized bodies of magma develops in the crust beneath the volcanic center. Magma mixing among andesitic magma batches is common, and eventually the enhanced heat causes crustal melting beneath volcanic centers and interaction between mafic and silicic magma bodies, leading to eruption of intermediate and silicic lavas (Borg and Clynne, 1998). Geochemical diversity of rocks decreases with time in volcanic centers, attesting to the increasing importance of homogenization in the magmatic systems during their evolution (Clynne, 1990; Bullen and Clynne, 1990).

Volcanic centers are the surface expression of a magmatic cycle driven by a local increase in regional magmatic flux that waxes as the crust is heated and wanes as the easily fusible component of the lower crust is depleted. During the andesitic phase of volcanic centers, magmatic fractionation is dominated by crystal fractionation of basalt with a relatively small contribution from the crust. As the evolution of volcanic centers proceeds, the crustal component becomes increasingly important until, in the later stages, it dominates the magmatic system. The origin of the increased magmatic flux that initiates volcanic centers is unclear; it may be caused by structures that focus magma at the base of the crust or within the lower crust (Blakely and others, 1997). Alternatively, it could be related to inhomogeneities of magma production in the mantle wedge or even to heterogeneities at the slab-wedge interface. Volcanic centers do not significantly overlap in space, possibly as a result of the depletion of the easily fusible component in the lower crust that is required for production of large volumes of silicic magma. Volcanism in volcanic centers has been nearly continuous somewhere in the Lassen area over the past 3.5 m.y. Typically, a single volcanic center becomes extinct before or as the next center becomes active. During the early Pleistocene, however, the life spans of the Maidu and Dittmar Volcanic Centers coincided (fig. 7).

\section{Eruptive History of the Lassen Area}

\section{Regional Volcanic Rocks}

Over the past 3.5 m.y., regional calc-alkaline volcanism in the Lassen segment of the Cascade Arc constructed a broad platform of volcanic rocks in a band straddling the present arc axis (figs. 2 and 3). A variety of these older lavas, erupted from shield volcanoes, lava cones, and scoria cones, are exposed in the mostly unglaciated terrane surrounding the LVC. North and east of the LVC, these older rocks commonly are broken into linear blocks bounded by faults. The volume of calc-alkaline regional volcanic rocks diminishes with distance both east and west from the arc axis, so that there are lesser volumes of fore-arc and back-arc volcanism. On a time scale of 50-200 thousand years (k.y.), regional volcanism is concentrated in local areas. Regional volcanism does not occur within the boundaries of active volcanic centers. There, rising mafic magmas are intercepted and processed, and thus they contribute to the magmatic system of the volcanic center. Return of regional volcanism within the boundaries of a volcanic center indicates solidification of that part of the center's magmatic system.

Within the regional lavas of the Lassen area are many young alignments of monogenetic cones and flows that share spatial, chemical, and lithologic characteristics. These are illustrated on this field trip by the Tumble Buttes, Sugarloaf, and Poison Lake chains (fig. 3).

LKOT is related to Basin and Range tectonics (Clynne, 1993), and it erupted across the Lassen region in a wave progressing from east to west that approximately coincides with progressive impingement of Basin and Range extension on the Cascade Arc (Guffanti and others, 1990). Although they produce relatively large volumes of lava, LKOT eruptions are relatively infrequent (Clynne and others, 2004), and, overall, LKOT is volumetrically subordinate to the dominant calcalkaline volcanism. Because LKOT lavas are readily buried by younger volcanism, some are likely hidden in the subsurface.

\section{Yana and Latour Volcanic Centers and the Tuscan Formation}

The oldest volcanic rocks in the vicinity of the present-day axis of the Cascade Range in the Lassen area make up the Yana and Latour Volcanic Centers. Rocks of the Yana Volcanic Center ( 3.4-2.4 Ma) dominate the area southwest of Lake Almanor, whereas rocks of the Latour Volcanic Center $(>3 \mathrm{Ma})$ are present northwest of LVNP. The evolution of the Yana Volcanic Center is understood in only a general sense, and even less is known 
about the Latour Volcanic Center. The Yana and Latour Volcanic Centers are dominantly andesitic, and the lithologies are similar to the better-known volcanic centers described below.

The Yana and Latour Volcanic Centers are important, however, as the primary sources of the Tuscan Formation, a broad volcanic and volcaniclastic wedge of fragmental material emplaced on the west slope of the southernmost Cascade Range (Anderson, 1933; Lydon, 1968; Helley and others, 1981; Helley and Harwood, 1985). The Tuscan Formation consists primarily of volcanic debris-flow deposits, conglomerate, sandstone, and siltstone, with minor silicic ash-flow and air-fall tuffs and sparse basaltic to andesitic lava flows. The Tuscan Formation originally covered about 5,000 km and had a volume of 1,200 km (Lydon, 1968). Adjacent to the Cascade Range, the Tuscan Formation is $\sim 500 \mathrm{~m}$ thick (Lydon, 1968) where it interfingers with proximal deposits of the Latour and Yana Volcanic Centers. It thins dramatically in distal areas to the west in the Sacramento Valley, where volcanic debris was reworked by fluvial processes (Harwood and others, 1981) and intercalated with fluvial sediments. The Tuscan Formation ranges in age from $\sim 3.5 \mathrm{Ma}$ (Helley and others, 1981; Helley and Harwood, 1985) to perhaps as young as $\sim 2.5 \mathrm{Ma}$. In some places, the uppermost part of the Tuscan Formation may be derived from the Dittmar Volcanic Center.

The Nomlaki Tuff Member of the Tuscan Formation is a dacitic ash flow tuff of regional extent found intercalated with the lower part of the Tuscan Formation in the northern Sacramento Valley. The Nomlaki Tuff Member was dated at about 3.3 Ma by Evernden and others (1964). Distal Nomlaki Tuff Member is widely found in the western United States, and its volume is probably in the range of 75-100 $\mathrm{km}^{3}$. The Nomlaki Tuff Member thickens dramatically towards the Latour Volcanic Center, its likely source, but no caldera has yet been located.

\section{Dittmar Volcanic Center}

The Dittmar Volcanic Center (2.4-1.3 Ma) lies at the northwest end of the Lake Almanor Graben (figs. 2 and 7). The volcanic center has been chopped into a number of fault blocks, and detailed stratigraphy cannot generally be traced across the faults or correlated among blocks. Consequently, the details of the center's evolution are poorly known. The Dittmar Volcanic Center hosted a hydrothermal system in its waning stages of activity; thus many of the early Dittmar rocks are hydrothermally altered. Glaciation of weak, hydrothermally altered rocks has deeply eroded the central area, and rocks are generally poorly exposed. Deposits of the Dittmar Volcanic Center are grouped into three stratigraphic stages (Clynne and Muffler, 2010): Stage 1 , early growth of the composite cone; Stage 2, later growth of the composite cone; and Stage 3, late silicic volcanism. The durations and ages of all three stages are poorly constrained.

Stage 1 consists of generally thin lava flows and interbedded fragmental deposits ranging from flow breccias, lithic fall deposits, and block-and-ash flow deposits to lahars. These lavas and volcanic deposits erupted from a central vent whose exact location has been obscured by erosion and other surficial processes. Olivine-bearing basaltic andesite and hypersthene-augite andesite dominate Stage 1; pyroxene \pm hornblende dacite to rhyolite are subordinate. Three $\mathrm{K}$-Ar ages from unaltered parts of the stratigraphic section are 2,315 $\pm 29 \mathrm{ka}$ from near the bottom and $1,785 \pm 35 \mathrm{ka}$ and $1,650 \pm 35 \mathrm{ka}$ from near the top. An ash-flow eruption probably produced a small caldera (Ingebritsen and Rojstaczer, 1983) during the andesitic part of Stage 1. An exploratory well $\sim 3$ miles south of LVNP intersected more than $150 \mathrm{~m}$ of ponded ash-flow tuff (authors' unpublished data). This tuff is dacitic and may be the same as an ash-flow tuff interbedded with Stage 1 andesites and seen as fragments in the debrisavalanche deposit at Stop A-1. Small erosional remnants of this tuff are found in the area of the Yana Volcanic Center.

Stage 2 consists of generally thick lava flows with sparse interbedded fragmental deposits. Lavas of Stage 2 erupted from flank vents whose locations are not preserved. Hypersthene-augite andesite dominates Stage 2; olivinebearing andesite and pyroxene \pm hornblende dacite are subordinate. A single K-Ar age is $1,398 \pm 42 \mathrm{ka}$.

Stage 3 consists of a few lava flows and domes of hornblende-biotite rhyodacite and rhyolite. No vents for these units are known. A single K-Ar age is 1,273 $\pm 7 \mathrm{ka}$.

\section{Maidu Volcanic Center}

The Maidu Volcanic Center (2.4-1.2 Ma) is located southwest of LVNP (fig. 7), where it unconformably overlies the Tuscan Formation and rocks of the Yana Volcanic Center (Clynne and Muffler, 2010). The summit and vent areas have been completely obscured by a combination of hydrothermal alteration and glacial and fluvial erosion. Although deeply eroded, the center is, in general, structurally intact. The total volume erupted was in excess of $200 \mathrm{~km}^{3}$. Deposits of the Maidu Volcanic Center are grouped into three stratigraphic stages: Stage 1, early growth of the composite cone; Stage 2, later growth of the composite cone; and Stage 3, late silicic volcanism.

Stage 1 is composed mostly of thin lava flows and fragmental deposits erupted from a central vent. Hyperstheneaugite andesite dominates; olivine-bearing basaltic andesite and pyroxene \pm hornblende dacite are subordinate. Stage 1 contains considerable intercalated fragmental deposits ranging from fallout to block-and-ash flow deposits; lahar deposits are common. The permeable fragmental deposits and brecciated flow carapaces are particularly susceptible to hydrothermal alteration. Stage 1 was active from 2.4 to $\sim 2.15 \mathrm{Ma}$.

Stage 2 is dominated by a small number of thick porphyritic augite-hypersthene dacite lava flows erupted from flank vents. These lava flows generally lack interbedded fragmental deposits. Stage 2 was active from $\sim 2.15$ to $\sim 2.05 \mathrm{Ma}$.

Stage 3 consists of five large, very extensive, and very thick felsic lava flows erupted between $\sim 1.3$ and $\sim 1.2 \mathrm{Ma}$. One is composed of porphyritic rhyodacite, and the other four are sparsely phyric rhyolite. These flows are some of the largest silicic lava flows in the Cascade Range, with an aggregate volume of $\sim 37 \mathrm{~km}^{3}$. 


\section{Lassen Volcanic Center}

Recently acquired geochronology (Lanphere and others, 1999, 2004) and consequent reinterpretation of rock units surrounding Brokeoff Volcano demanded reorganization of the three-stage stratigraphic description of the Lassen Volcanic Center (LVC) presented in our earlier publications (Clynne, 1984, 1990; Bullen and Clynne, 1990; Clynne and Muffler, 1989). The major stratigraphic divisions of the LVC are now designated as the Rockland caldera complex, Brokeoff Volcano, and the Lassen domefield (fig. 8; Clynne and Muffler, 2010). These eruptive stages are contiguous periods of lithologically correlated volcanism distinctly different from one another but linked by a common magmatic system. The Rockland caldera complex comprises the Rockland tephra (previously considered to be younger than Brokeoff Volcano) and a number of silicic rock units previously assigned to the Maidu and Dittmar Volcanic Centers (Clynne, 1984). Brokeoff Volcano was previously called Stages 1 and 2 of the LVC. The Lassen domefield consists of the dacite domefield and surrounding hybrid andesite lava flows on the central plateau area of LVNP and surrounding areas that we previously called Stage 3 of the LVC.

Rocks of the Lassen Volcanic Center range from basaltic andesite to rhyolite but are dominated by andesite and dacite (fig. 9).

The rate of eruption for the Lassen domefield appears to be significantly less than for the Rockland caldera complex and Brokeoff volcano. The Rockland caldera complex erupted $\sim 80 \mathrm{~km}^{3}$ of magma over its $\sim 215$-k.y. lifetime, a long-term average of $\sim 0.4 \mathrm{~km}^{3} / \mathrm{k}$.y. Brokeoff Volcano also erupted $\sim 80 \mathrm{~km}^{3}$ of magma over its $\sim 205$-k.y. lifetime, again a long-term average of $\sim 0.4 \mathrm{~km}^{3} / \mathrm{k}$.y. In contrast, the Lassen domefield erupted only $\sim 40 \mathrm{~km}^{3}$ over its 315 -k.y. lifetime, a long-term average of $\sim<0.15 \mathrm{~km}^{3} / \mathrm{k}$.y. This output, however, was interrupted by a hiatus of $100 \mathrm{k} . \mathrm{y}$. between $190 \mathrm{ka}$ and $90 \mathrm{ka}$. The rate for the Lassen domefield both before and after the hiatus was $\sim 0.2 \mathrm{~km}^{3} / \mathrm{k}$.y. All of these estimates are unavoidably approximate.

Inspection of the well-preserved youngest volcanic activity of the Lassen domefield, however, suggests that volcanic activity probably occurs in short episodes, so that the short-term eruptive rate is variable. For example, the three eruptions at LVC in the Holocene (the past 11,700 years) total $\sim 2 \mathrm{~km}^{3}$, giving an eruptive rate of $\sim 0.17 \mathrm{~km}^{3} / \mathrm{k}$.y., similar to the long-term rate of the Lassen domefield. All three eruptions, however, occurred within the past 1,100 years, making the eruptive rate during this short period much higher $\left(\sim 1.8 \mathrm{~km}^{3} / \mathrm{k} . \mathrm{y}\right)$.

\section{Rockland Caldera Complex}

The Rockland caldera complex consists of the Rockland tephra and a group of dacite to rhyolite domes and flows ranging in age from $\sim 825$ to $\sim 600 \mathrm{ka}$. Extrusion of these domes and flows culminated in eruption of the Rockland tephra at $609 \pm 7 \mathrm{ka}$ (Lanphere and others, 1999, 2004).
The Rockland tephra was first recognized by Wilson (1961) as the "Rockland rhyolite pumice tuff breccia." A coeval distal ash-fall deposit is widely distributed in northern and central California, northeast to Idaho, and in deep-sea cores taken off the northern California coast (Sarna-Wojcicki and others, 1985).

Wilson (1961), Helley and others (1981), and Meyer and others (1991) attributed the Rockland deposits to the Maidu Volcanic Center; indeed, Helley and others (1981) called the unit the "ash of Mount Maidu." Clynne (1984) recognized that the Rockland deposits were younger than the Maidu Volcanic Center and, on the basis of a fission-track age of $\sim 400 \mathrm{ka}$ (Meyer and others, 1980, 1991), attributed the Rockland tephra to the LVC. This fission-track age was younger than Brokeoff Volcano, and, thus, the Rockland tephra was thought possibly to be the initial eruption of the Lassen domefield of the LVC. Subsequent precise dating determined the Rockland tephra to be $609 \pm 7 \mathrm{ka}$ (Lanphere and others, 1999, 2004), slightly older than Brokeoff Volcano. The calculated volume of the Rockland tephra is $\sim 50 \mathrm{~km}^{3}$ (dense rock equivalent; Sarna-Wojcicki and others, 1985), which is similar to that of the Mazama ash from Crater Lake (Bacon, 1983). An eruption of this magnitude must have formed a collapse caldera. Projection of the outcrop pattern of proximal deposits points towards Brokeoff Volcano, and it seems likely that eruption of the Rockland tephra produced a small caldera that has subsequently been filled by Brokeoff Volcano and younger products of the LVC.

Clynne (1984) also recognized a number of silicic rock units older than Brokeoff Volcano and the Rockland tephra, and he assigned them to the Maidu and Dittmar Volcanic Centers. Subsequent radiometric dating and improved understanding of the evolution of the Maidu and Dittmar Volcanic Centers showed these silicic rock units to be unrelated to those centers. Instead, these silicic rock units form a ring around the inferred source of the Rockland tephra and, thus, are now grouped with the Rockland tephra as the Rockland caldera complex (Clynne and Muffler, 2010). Lithic fragments from several of these silicic rock units are present in the Rockland tephra. These relations support our hypothesis that the Rockland tephra was erupted from a caldera located at the present site of Brokeoff Volcano.

\section{Brokeoff Volcano}

Brokeoff Volcano, also designated "Mount Tehama" by the National Park Service, consists of a large, $80-\mathrm{km}^{3}$, composite volcano. Almost immediately after eruption of the Rockland tephra, its caldera began to fill as renewed activity formed Brokeoff Volcano. Clynne and Muffler (2010) describe the stratigraphy of Brokeoff Volcano as two sequences of deposits: the Mill Canyon sequence and the Diller sequence.

The Mill Canyon sequence consists of dozens of smallvolume basaltic andesite to dacite lava flows and interbedded fragmental deposits erupted from a central vent between about 590 and $470 \mathrm{ka}$. The sequence is dominated by packages of 


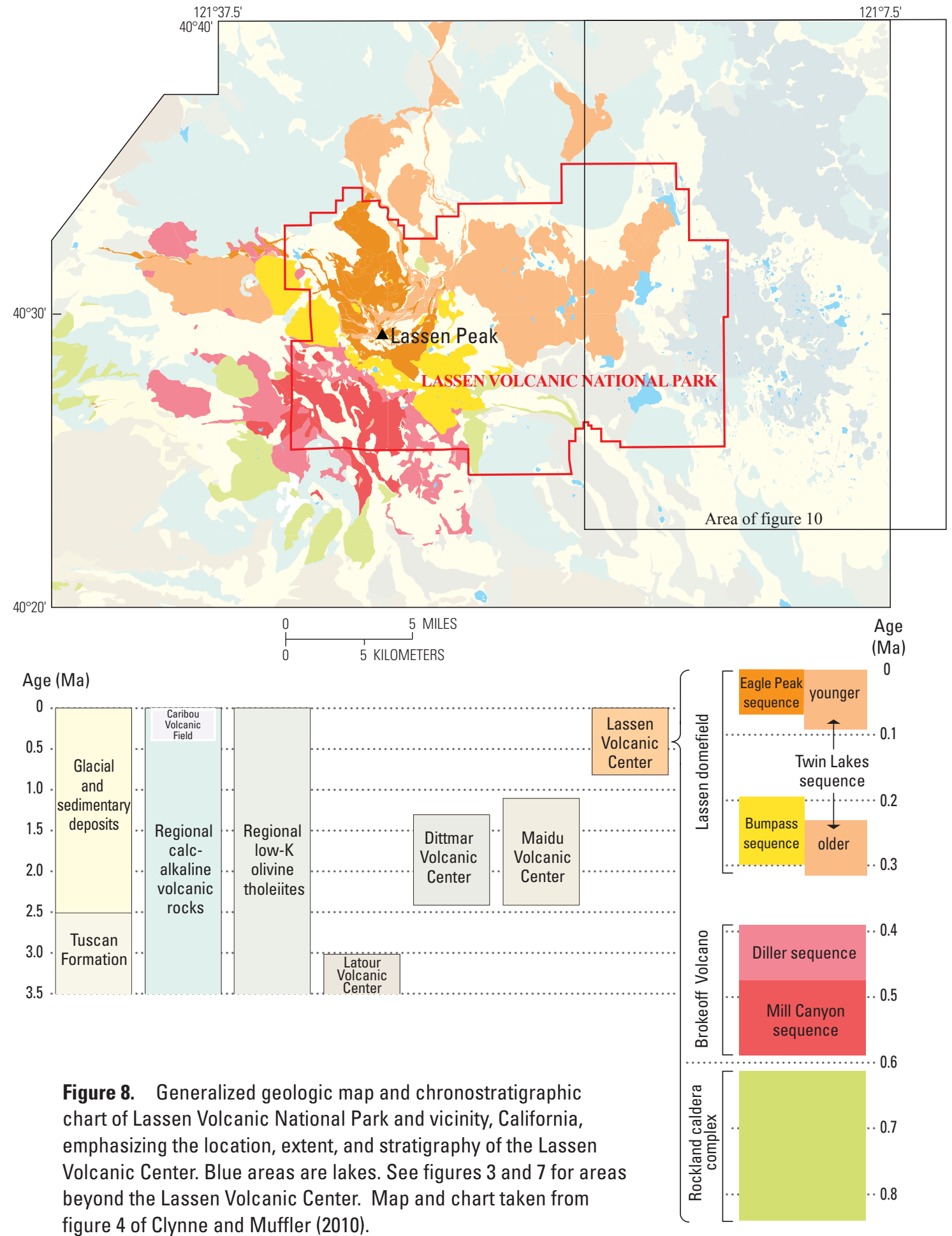


thin andesite lava flows and monolithologic breccias. Adjacent flow packages are of different lithologies, and a wide variety of porphyritic olivine and pyroxene basaltic andesites and andesites to pyroxene-hornblende dacites are present. The Mill Canyon sequence is capped by thick dacite lava flows erupted at $470 \mathrm{ka}$ (the dacite of Twin Meadows). This dacite is the only rock unit of significant lateral extent in Brokeoff Volcano and provides a convenient stratigraphic boundary between the Mill Canyon sequence and the overlying Diller sequence.

The Diller sequence consists primarily of six thick, large-volume, lithologically similar lava flows that erupted from flank vents between 470 and $385 \mathrm{ka}$. These flows consist of porphyritic augite-hypersthene andesite to silicic andesite and generally lack interbedded pyroclastic deposits. The lithologic, petrographic, and geochemical characteristics of the Mill Canyon and Diller sequences indicate a change in the Brokeoff Volcano magmatic system between those periods. During Mill Canyon time, evolving magma batches were small and temporally or physically isolated so that a diversity of lithologies was erupted. In contrast, during Diller time, the magmatic system was more integrated, and more voluminous lavas of relatively constant composition were erupted.

Williams (1932) proposed that the eroded core of Brokeoff Volcano was a collapsed caldera. Our mapping, however, has failed to reveal either caldera-bounding faults or any pyroclastic deposit that could be related to a caldera. The eviscerated core of Brokeoff Volcano appears to be the product of glacial and fluvial erosion of weak, hydrothermally altered rock, and much of the core area now consists of material emplaced by landslides (see figure 19 of Clynne and others, 2012). The largest remnants of Brokeoff Volcano (Brokeoff Mountain and Mount Diller) were protected from erosion by thick, unaltered, lava flows of the Diller sequence on their outer flanks.

\section{Lassen Domefield}

No volcanism is recognized in the LVC between about 385 and $315 \mathrm{ka}$. After this hiatus, the character and locus of volcanism in the LVC changed dramatically from the andesitic stratocone to the Lassen domefield, which consists of a core of dacite domes surrounded by an arc of hybrid andesite flows. The dacite domes erupted along the northern flank of Brokeoff Volcano and are divided on the basis of age into the Bumpass ( 300-190 ka) and Eagle Peak ( 70-0 ka) sequences. The hybrid andesite units erupted in two groups called the older ( 315- 240 ka) Twin Lakes sequence and the younger ( $\sim 90-0 \mathrm{ka})$ Twin Lakes sequence, which are contemporaneous with the Bumpass and Eagle Peak sequences, respectively. No volcanism is known in the LVC during the period 190-90 ka.

The Bumpass sequence is a group of 15 dacite to rhyodacite lava domes and flows emplaced between $\sim 300 \mathrm{ka}$ and $\sim 190 \mathrm{ka}$ as a broad curvilinear array in the south part of the Lassen domefield. Repeated glaciation has removed glassy dome carapaces and most of the fragmental deposits associated with domes and flows; only a single lithic pyroclastic-flow deposit is preserved. Lavas of the Bumpass sequence are mostly porphyritic pyroxene and hornblende
Figure 9. Graph of $\mathrm{SiO}_{2}$ content versus $\mathrm{K}_{2} \mathrm{O}$ content for 250 analyses of volcanic rocks from the Lassen Volcanic Center grouped by eruptive sequence. The Rockland caldera complex is dominated by dacite to rhyolite, Brokeoff Volcano is dominated by andesite, and the Lassen domefield (Bumpass, Eagle Peak, and Twin Lakes sequences) is dominated by dacite to rhyodacite. Basalt input is expressed as quenched mafic inclusions in the Bumpass and Eagle Lake sequences and as andesitic hybrid lavas of the Twin Lakes sequence (Clynne, 1990; Bullen and Clynne, 1990).

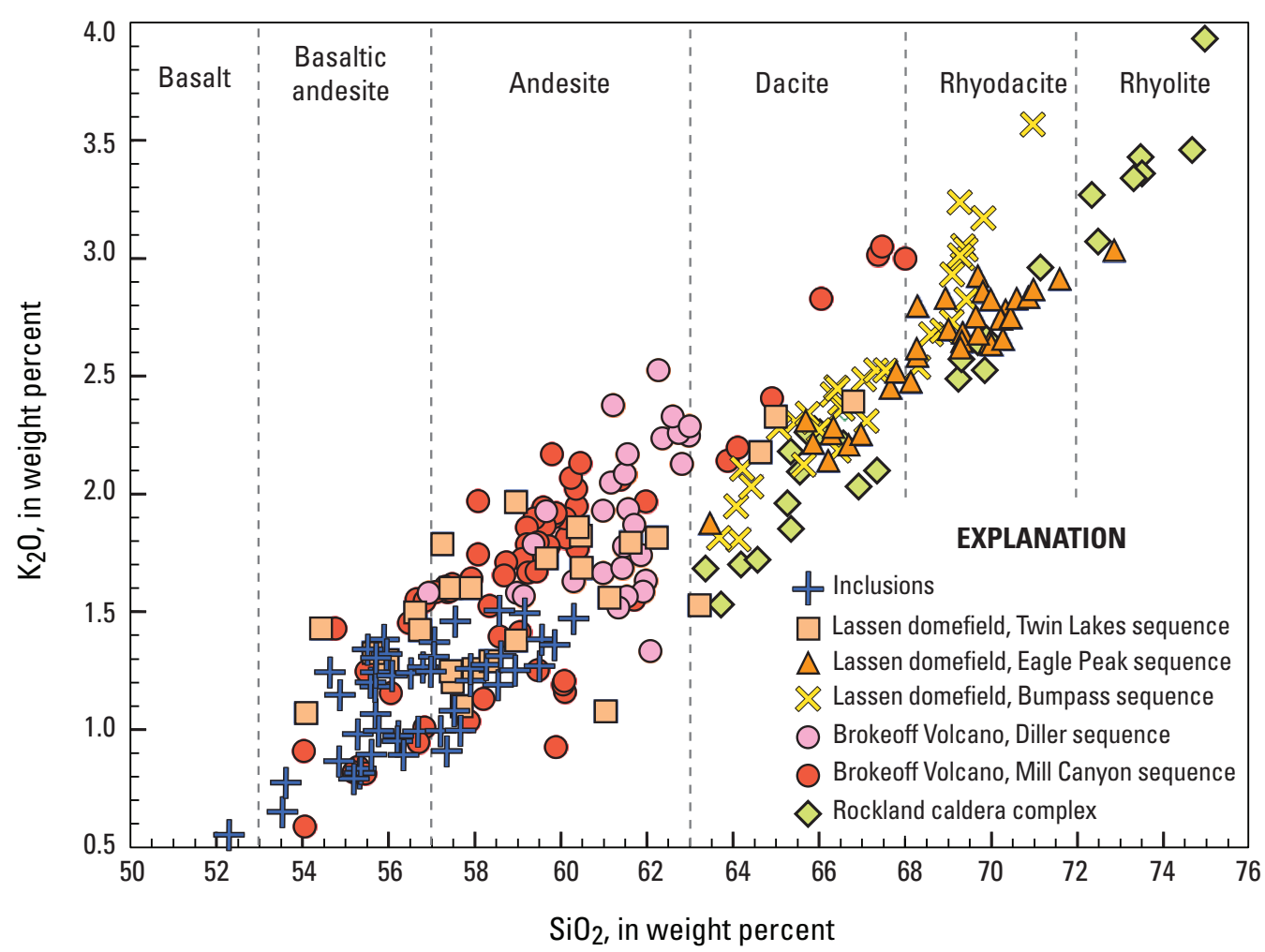


dacite; quartz and biotite are generally sparse. A few lavas are porphyritic biotite-hornblende rhyodacite. Quenched mafic inclusions (enclaves) are sparse to abundant. The Bumpass sequence is characterized by disequilibrium phenocryst assemblages that originated by mixing of a small proportion of regional mafic magma with rhyodacite of the Lassen domefield magmatic system.

The Eagle Peak sequence comprises seven units of dacite and rhyodacite lava domes and flows and their associated pyroclastic deposits that erupted in the north part of Lassen domefield. These include the two most prominent young volcanic features in LVNP: Lassen Peak ( $27 \pm 1 \mathrm{ka})$ and Chaos Crags $(1,103 \pm 13 \mathrm{ka} ; \sim 850$ C.E. $)$, as well as the products of five older eruptions. All units of the Eagle Peak sequence excepting Chaos Crags are glaciated, but the degree of glacial erosion is much less than on domes of the Bumpass sequence, and significant portions of glassy carapaces, primary hot talus, and pyroclastic deposits are preserved. Lavas of the Eagle Peak sequence are porphyritic hornblende and biotite dacite and rhyodacite; some also contain quartz. Like the Bumpass sequence, the Eagle Peak sequence is characterized by disequilibrium phenocryst assemblages and quenched mafic inclusions that originate by mixing of a small proportion of regional mafic magma with rhyodacite of the active Lassen domefield magmatic system.

The Twin Lakes sequence consists of two groups of mostly andesite and basaltic andesite lava flows and agglutinate cones erupted around the periphery of the Lassen domefield, but primarily on the central plateau of LVNP. The older group of lava flows is correlative with the Bumpass sequence, and the younger group is correlative with the Eagle Peak sequence. The two youngest eruptions in LVNP, the basaltic andesites of Cinder Cone and deposits of the 1914-17 eruption of Lassen Peak, are parts of the younger Twin Lakes sequence. Rocks of the Twin Lakes sequence have pronounced disequilibrium phenocryst assemblages that are characterized by coexistence of magnesian olivine and quartz. Except for Cinder Cone (see detailed description at Stop G-3), they originate by mixing of subequal proportions of regional mafic magma and rhyodacite of the Lassen domefield magmatic system.

The Bumpass, Eagle Peak, and Twin Lakes sequences belong to a suite of lavas formed by a continuum of magmamixing processes between a basaltic component equivalent to the regional basaltic volcanism and a rhyolitic component generated by melting of solidified basalt underplated or intruded into the lower crust (Borg and Clynne, 1998; Feeley and others, 2008a). Compositional variation of the Bumpass sequence (and the earlier Rockland caldera complex) is dominated by the felsic melt. The youngest Lassen dacites (Eagle Peak Sequence) evolved by introduction of regional mafic magma into a reservoir containing residual felsic melt and phenocrysts that is probably too cool and viscous to erupt. Mixing of hot mafic magma and its phenocrysts with cool crystal mush, partial resorption of phenocrysts in the host dacite, quenching of the resultant mixed magma to form undercooled inclusions, and circulation and disaggregation of inclusions back into the host dacite created complex disequilibrium phenocryst assemblages (Clynne, 1999). Phenocryst abundance, character, and even assemblage can vary within individual dacite domes, and intradome variability can be as large as interdome variability. The two fundamental factors controlling the character of the erupted magma are the relative proportions of mafic and silicic components in the mixture and the length of time between the mixing event(s) and eruption. When the relative proportions of mafic and silicic components approach unity, inclusions are no longer formed, and the magmas mix homogeneously to form hybrid magmas. Hybrids (Twin Lakes sequence) are typically andesitic in bulk composition and are usually characterized by strongly resorbed phenocrysts and the coexistence of magnesian olivine and quartz as phenocrysts.

\section{Holocene Volcanic Activity}

The LVC is still active, and three eruptions have occurred in the Holocene: Chaos Crags, Cinder Cone, and the 1914-17 eruption at the summit of Lassen Peak. Chaos Crags is part of the Eagle Peak sequence, whereas Cinder Cone and the eruption at the summit of Lassen Peak are part of the younger Twin Lakes sequence. No other Holocene eruptions have been documented in the Lassen region.

Chaos Crags, located northwest of Lassen Peak, erupted at 1,103 \pm 13 B.P. ( $\sim 850$ C.E.; Clynne and others, 2002$)$ and is the youngest unit of the Eagle Peak sequence. As mapped by Christiansen and others (2002), the eruptive sequence consists of a group of six rhyodacite lava domes and associated pyroclastic deposits that define a typical silicic eruption in the LVC. Chaos Crags lavas are porphyritic hornblende-biotite rhyodacite that contains a complex disequilibrium phenocryst assemblage characteristic of Lassen dacites (Clynne, 1999). Quenched mafic inclusions are sparse to rare in the early rhyodacite lavas (generally less than 1 percent to a few percent), whereas they form as much as 20 percent of the late rhyodacite lavas.

Cinder Cone, located in the northern part of LVNP, is the youngest mafic volcano in the Lassen region and the second youngest eruption in the Twin Lakes sequence. Radiocarbon, stratigraphic, paleomagnetic, and dendrochronologic data (Clynne and others, 2000a, 2002; Sheppard and others, 2009) indicate that Cinder Cone erupted in 1666 C.E., not in 1851 C.E. as cited in earlier literature going back to Harkness (1875). Cinder Cone consists of five lava flows of basaltic andesite to andesite composition, two nested scoria cones, and a widespread mafic ash-fall deposit.

The 1914-17 eruption of Lassen Peak is the most recent eruption in the Twin Lakes sequence. It comprises a complex eruptive sequence consisting of a dacite dome and lava flow, dacite pyroclastic flow and fall deposit, and phreatic, avalanche, debris-flow, and flood deposits (Clynne and others, 2014; Christiansen and others, 2002; Clynne, 1999). The eruptive sequence began on May 30, 1914, with a phreatic explosion at the summit of Lassen Peak. By mid-May 
of 1915 , more than 180 steam explosions had blasted out a 300 -m-long crater at the summit. Magmatic activity was confined to the period from about May 14 to May 22, 1915, and affected primarily the northeast flank and slope of Lassen Peak (now called the Devastated Area) and the valleys of Lost and Hat Creeks as far as about 30 miles $(50 \mathrm{~km})$ downstream. Rock types range from olivine andesite to several varieties of hornblende-biotite dacite with abundant quenched mafic inclusions and complex mineralogy. Spectacularly banded pumice blocks, erupted on May 22, serve to distinguish the May 22 deposits from those of May 14-19.

\section{Caribou Volcanic Field}

The Caribou Volcanic Field (CVF) is an area of intense, young regional volcanism located 20-30 km east of the LVC (figs. 7 and 10). The field is composed of monogenetic scoria cones, flows, and small- to medium-size lava cones, generally of mafic composition, and is distinguished from older regional mafic lavas around its periphery by substantial constructional morphology and the absence of significant structural

disruption. The CVF ( 425-0 ka) is contemporaneous with the later part of the LVC and is the result of a higher flux of magma from the mantle compared to the Lassen segment of the arc as a whole, but not as high as that at the LVC (Guffanti and others, 1996). The CVF may represent an incipient volcanic center that is not quite vigorous enough to initiate crustal melting and silicic volcanism. No single edifice has a long history of activity. CVF volcanoes erupted in nine arrays discriminated by spatial, temporal, and compositional characteristics. Some arrays were active for only a few thousand years (for example, the Poison Lake chain), whereas several others (such as the Caribou chain) were active for periods as long as 100-200 k.y. Emplacement of arrays is generally structurally controlled; that is, linear arrays of vents bury active or inactive faults that provided pathways exploited by ascending magma and acted to focus volcanism at the surface.

The older part of the CVF consists of the Caribou chain (425-275 ka) - a large, extensively glaciated massif that dominates the Caribou Wilderness, just east of LVNP — and 4 contemporaneous groups of volcanoes peripheral to the Caribou chain (Cone Lake chain, Sunrise Peak sequence, Beauty Lake sequence, and Island Lake sequence) that range in age from 450-200 ka. The younger part of the CVF consists of 4 chains of volcanoes $<110 \mathrm{ka}$. Most prominent is the weakly glaciated Red Cinder chain $(\sim 100$ to $\sim 25 \mathrm{ka})$, located on the border of LVNP and the Caribou Wilderness. To the northeast, the Poison Lake chain is unglaciated, and the constructional forms of its 39 young basalt and basaltic andesite scoria cones and lava flows (110-100 ka) are well preserved (Muffler and others, 2011). Margins of the flows of the Bidwell Spring chain (one date of $46.3 \pm 3.4 \mathrm{ka}$ ) are slightly overlapped by till, particularly on the west side, but most of the prominent scoria cones are unglaciated. The CVF also contains two chains of tuyas (flattopped subglacial volcanic constructs); the older is either 130$120 \mathrm{ka}$ or $\sim 60 \mathrm{ka}$, and the younger is $35-17 \mathrm{ka}$.

\section{Glacial Geology}

At least five episodes of Pleistocene glaciation are recognized in the Lassen area (Crandell, 1972; Kane, 1982; Colman and Pierce, 1992; Turrin and others, 1998). A comparison of different workers' depictions of the Lassen area glacial geology is presented in figure 11 .

In the Lost, Hat, and Manzanita Creek drainages, Christiansen and others (2002) recognized and mapped six ages of glacial deposits intercalated with volcanic rocks of the Eagle Peak sequence. Use of this detailed glacial unit terminology was partially extended in collaboration with Robert Christiansen to the Bailey and Digger Creek drainages (Clynne and Muffler, 2010). In all areas outside of these drainages, Clynne and Muffler (2010) divided glacial deposits simply into older and younger units. Extension of the detailed glacial stratigraphy beyond the Lost, Hat, and Manzanita Creek drainages represents an important remaining geologic mapping problem in the Lassen region.

\section{Hydrothermal Features}

The Lassen geothermal system (fig. 12) consists of a central vapor-dominated reservoir underlain by a reservoir of hot water at a temperature of $240{ }^{\circ} \mathrm{C}$ (Muffler and others, 1982; Ingebritsen and Sorey, 1985; Clynne and others, 2003). Morgan Hot Springs and Growler Hot Spring are located in the canyon of Mill Creek 3,200 ft (975 m) below Bumpass Hell, at the contact between Brokeoff Volcano and the underlying Maidu Volcanic Center (fig. 12, top panel; fig. 13). These springs mark the lateral discharge of nearneutral, chloride-bearing hot water from the deep hot-water reservoir under Bumpass Hell. In contrast to the acid-sulfate alteration at Bumpass Hell, Morgan Hot Springs and Growler Hot Spring deposit silica sinter. Deep hot water also was encountered in a commercial geothermal well at Terminal Geyser, in an area subsequently incorporated into Lassen Volcanic National Park. This deep hot water may be from a separate geothermal upflow centered at either Devils Kitchen or Boiling Springs Lake in the southeast part of the park (fig. 13; fig. 12, bottom panel; Janik and McLaren, 2010). Heat loss from the thermal areas of Bumpass Hell, Sulphur Works, Pilot Pinnacle, and Little Hot Springs Valley totals 56 megawatts (MW), whereas the heat loss from Devils Kitchen and Boiling Springs Lake totals 49 MW (Sorey and Ingebritsen, 1995).

\section{Volcano-Related Hazards}

Clynne and others (2012) comprehensively evaluated five classes of volcano-related hazards in the Lassen region: (1) regional mafic lava flows and ash, (2) silicic lava domes, flows, and pyroclastic flows, (3) lahars, (4) hydrothermal hazards, and (5) landside and rockfall hazards. Robinson and Clynne (2012) presented details and modeling of 


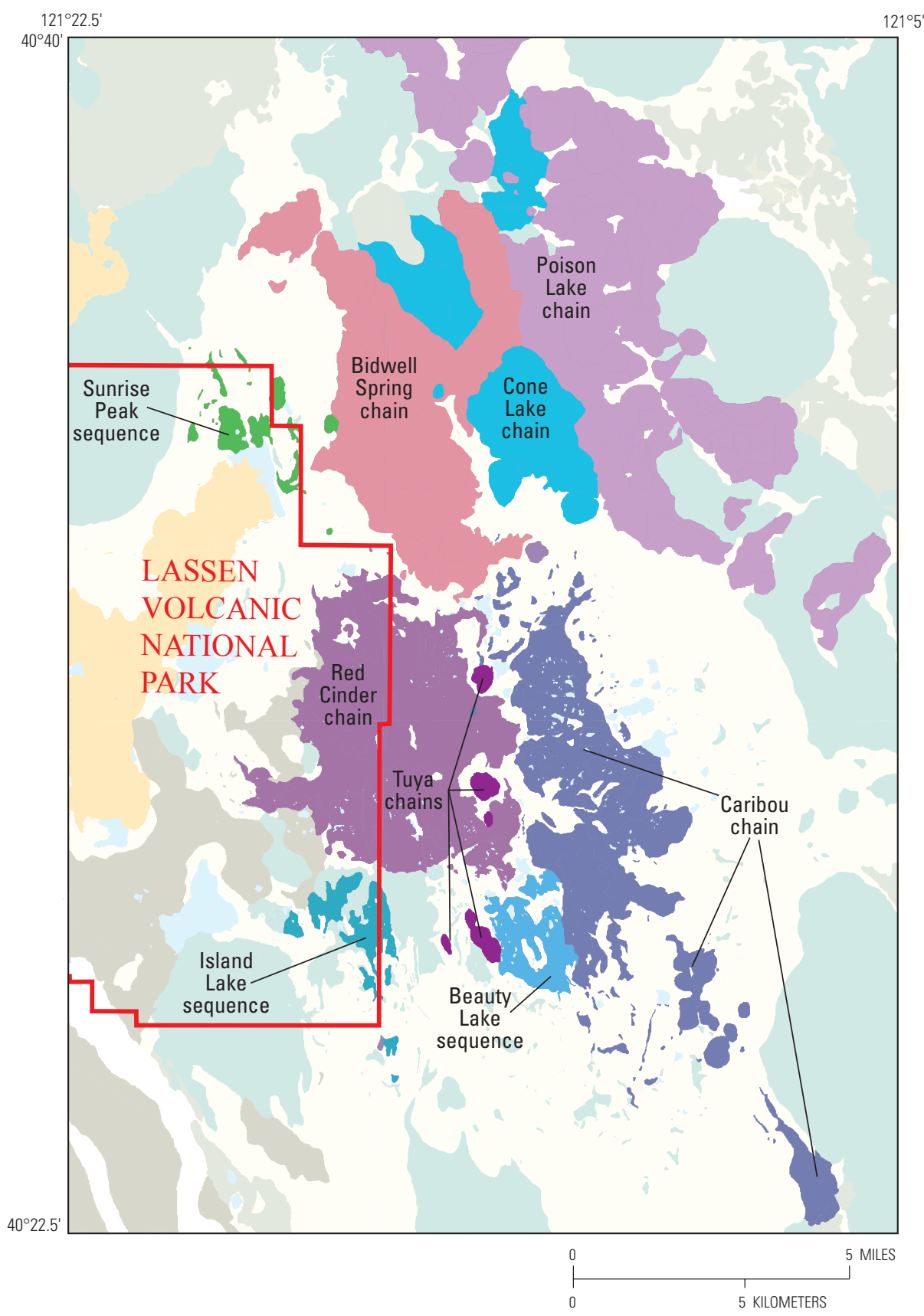

Figure 10. Generalized geologic map of eastern part of Lassen Volcanic National Park and adjacent areas, emphasizing the location and extent of volcanic sequences and chains in the Caribou Volcanic Field. Lighter colors are units not part of Caribou Volcanic Field (see fig. 7). Map adapted from figure 6 of Clynne and Muffler (2010). 


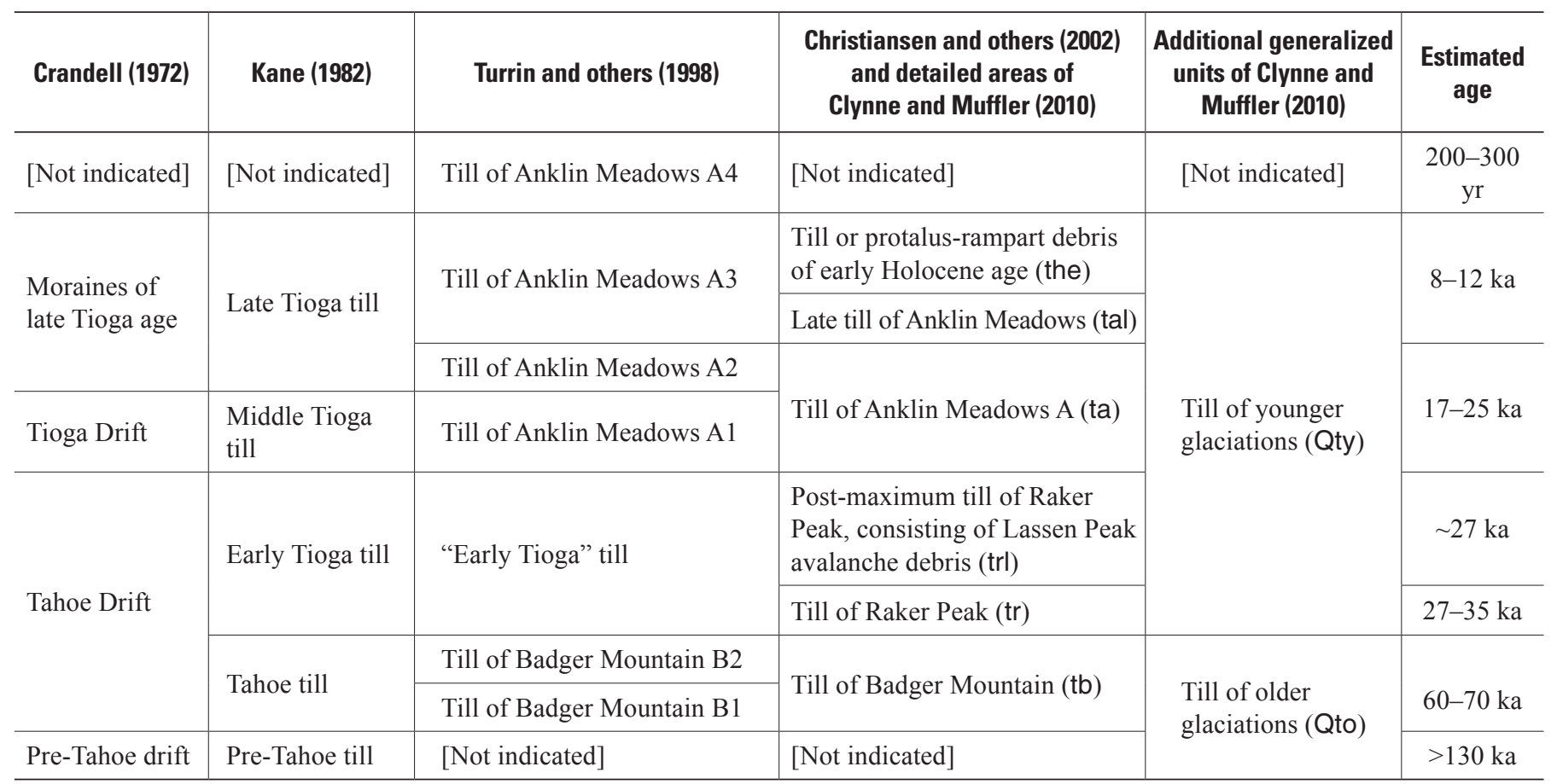

Figure 11. Chart showing correlation of glacial terminology, ages, and depiction of glacial deposits in the Lassen area by various authors. From table 1 of Clynne and Muffler (2010). In most parts of the Geologic Map of Lassen Volcanic National Park and Vicinity (Clynne and Muffler, 2010), glacial deposits are divided simply into younger and older tills. In general, till of younger glaciations (Qty) has well-preserved moraines, whereas till of older glaciations (Qto) has only moderately to poorly preserved moraines. The boundary between the two tills corresponds to the boundary between middle Wisconsin and early Wisconsin glacial stages as defined by Colman and Pierce (1992), or approximately to the Tioga and Tahoe glacial advances as these terms are used by Kane (1982). Estimated ages in the last column should be applied neither to the terms used by Crandell (1972) and Kane (1982) nor to the terms "Tahoe" and "Tioga" in other regions. Furthermore, the interpretations of Clynne and Muffler (2010) do not always agree with those of Crandell (1972) and Kane (1982). For example, in the Bailey Creek drainage northwest of Brokeoff Mountain, the contact of Clynne and Muffler (2010) lies between that shown by Crandell (1972) and that shown by Kane (1982). 
Figure 12. Diagrammatic cross sections of the Lassen hydrothermal system. The upper, north-south cross section illustrates circulation in cell 1 of Janik and McLaren (2010), whereas the lower, east-west cross section illustrates circulation in their cell 2. In both cells, meteoric water percolates to depth and is heated by hot rock overlying a body or bodies of magma (shown generalized and diagrammatically). Hot water rises convectively and boils in response to decreasing pressure to form a vapor-dominated zone that releases steam and gases to surface fumaroles and acidic hot springs. The residual thermal water flows laterally and emerges as hot springs south of the park (cell 1) and was encountered in a now-abandoned geothermal well at Terminal Geyser (cell 2). Approximate depths indicated are below ground surface. Taken from figure 14 of KellerLynn (2014), in turn based on Janik and McLaren (2010), Clynne and others (2003), and Muffler and others (1982).

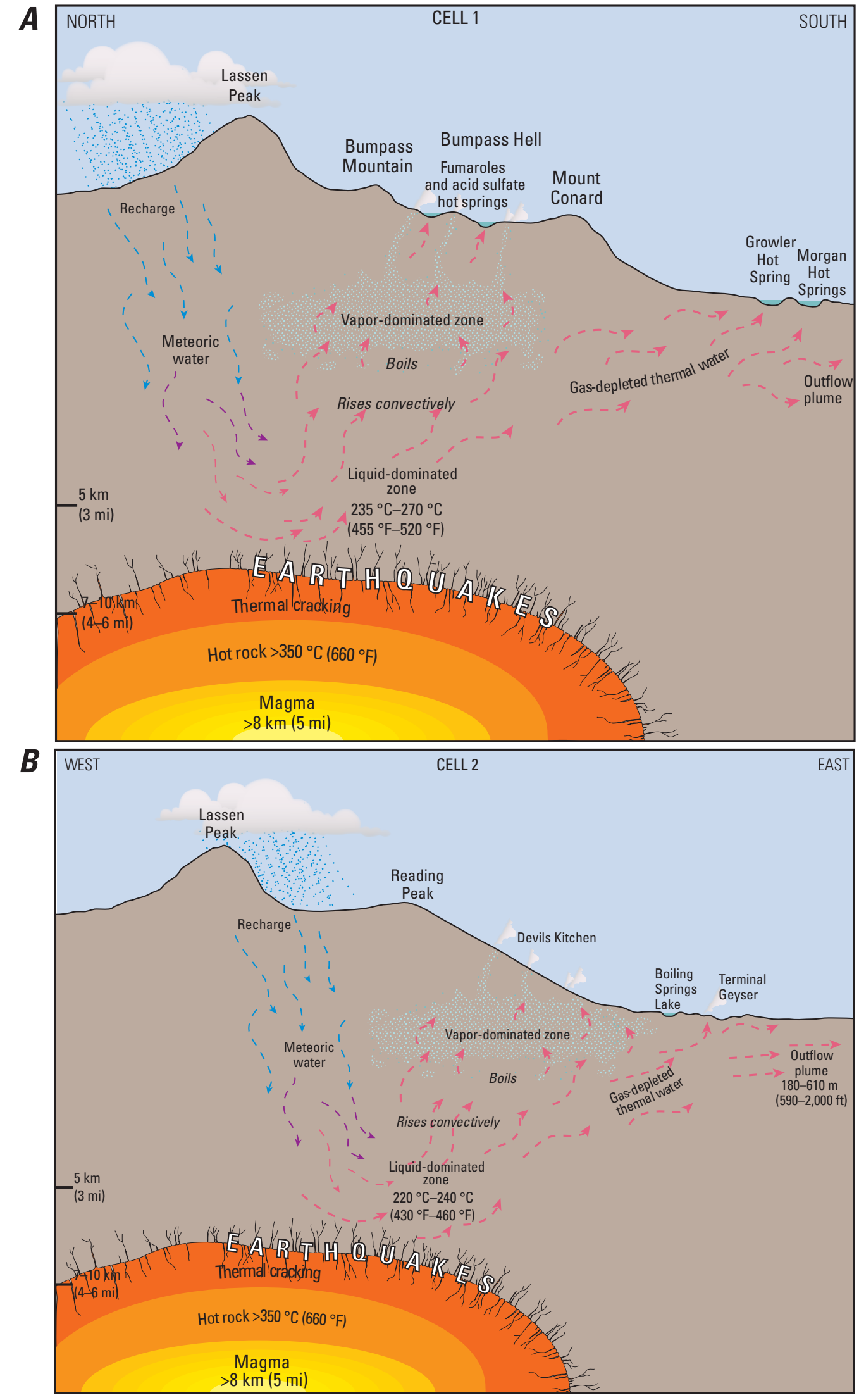


lahar hazards, and Nathenson and others (2012) analyzed eruption probabilities. The average recurrence interval for regional mafic volcanism is 1,550 years, whereas the average recurrence interval for the Lassen Volcanic Center is 7,150 years. Hydrothermal hazards and landslide hazards are ongoing, particularly in the erosional amphitheater in Brokeoff Volcano (figure 19 of Clynne and others, 2012). Lahar hazards are primarily in the drainages heading in the high-elevation terrain around Lassen Peak, in particular Lost Creek, Hat Creek, and Manzanita Creek (Robinson and Clynne, 2012; figure 10 and plate 1 of Clynne and others, 2012).

\section{Road Log}

Reading the "Geological Overview" section above before launching into the road log will acquaint the user with the geologic framework and the stratigraphic terminology of the Lassen area, thus providing a context for specific discussions in the road log.

Numbers at left are distances in miles from starting point. Numbers in bold at the end of each entry are the distance in miles to the next entry. View directions are indicated by reference to a clock face-12:00 means straight ahead, 9:00 means $90^{\circ}$ to left, $3: 00$ means $90^{\circ}$ to right.

\section{Section A: Red Bluff to Intersection of Calif. Hwys 36 and 89}

0.0 At Red Bluff, head east from Interstate 5 on Calif. Hwys 36 and 99. Bluffs at 12:00 are Tuscan Formation, with Lassen Peak on the skyline. Tuscan Buttes are at 11:30. 2.1

2.1 Turn left on Calif. Hwy 36 towards Susanville and Lassen Volcanic National Park. Highway is on the flood plain of the Sacramento River. 0.8

2.9 At 2:00, view over Tuscan Formation towards Tuscan Buttes. 0.9

3.8 Roadcuts in Pleistocene terrace gravels related to the Sacramento River. 0.4

4.2 Large roadcuts on both sides of road in Pleistocene terrace gravels. 0.5

4.7 Contact of Pleistocene terrace gravels with the underlying Tuscan Formation $(\sim 3.5$ to $\sim 2.5 \mathrm{Ma})$. Weathering and erosion of the debris-flow matrix of the Tuscan Formation produces a characteristic "stony plain." 0.4

5.1 Mount Shasta visible in distance at 10:30. 1.9

7.0 Boundary of Red Bluff East quadrangle with Bend quadrangle to the north. $\mathbf{0 . 4}$

7.3 On left is BLM parking area for Sacramento River Bend, Iron Canyon Trailhead. To west at 9:00 across the Sacramento River are the northern Coast Ranges.

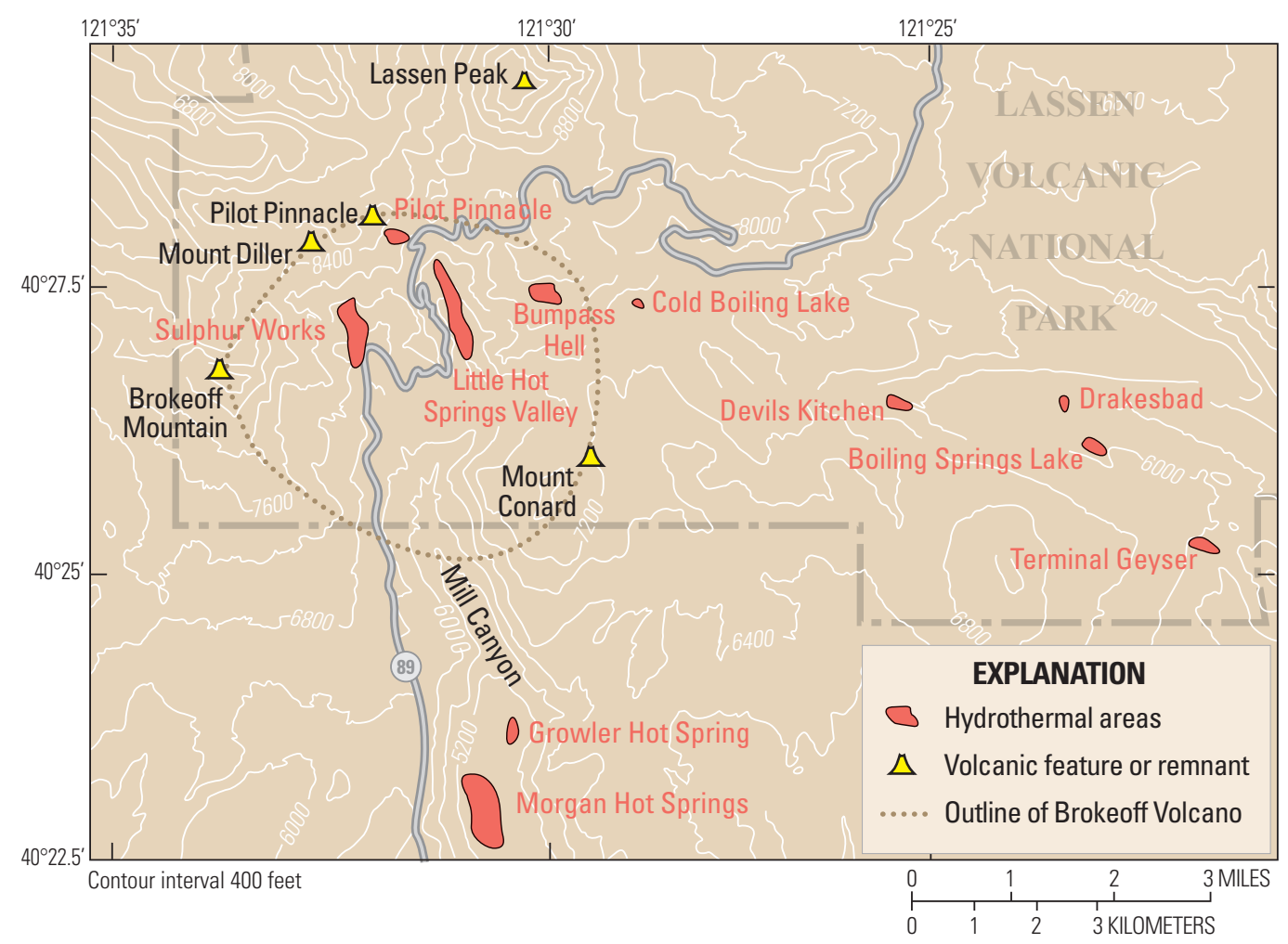

Figure 13. Map showing thermal areas in and adjacent to Lassen Volcanic National Park. From figure 8 of Clynne and others (2012). 
East of the highway at 1:00 across the stony plain of the Tuscan Formation are the Tuscan Buttes. 1.6 In the distance ahead is the scarp of the east-weststriking Battle Creek Fault (fig. 14), mapped and described by Helley and others (1981), Helley and Harwood, (1985), Harwood (1987), and Blake and others (1999). Age data from Marvin Lanphere (written commun., 1997) indicate that the 950-750-ka lava flows draping the Battle Creek Fault scarp are progressively less offset with decreasing age. A 562-ka lava flow ponded at the base of the scarp is barely offset, and a 60-ka lava flow from Black Butte (Page and Renne, 1994) that crosses the fault is not offset.

For the next several miles, Calif. Hwy 36 is on Tuscan Formation, but the oak-covered low bluffs on both sides of the road are a thin lava flow of the overlying tholeiitic basalts of Coleman Forebay. In the distance ahead is Magee Volcano, with Soap Butte in the middle ground. $\mathbf{0 . 2}$
9.1 Boundary of Bend quadrangle with Dales quadrangle to the east. $\mathbf{0 . 4}$

9.5 On left is BLM parking area for Hog Lake Plateau. A thin $(\sim 1 \mathrm{~m})$ basalt flow of the tholeiitic basalts of Coleman Forebay is exposed in the highway roadcuts, overlying a baked zone in the Tuscan Formation. On right is the service road to microwave and cell towers on Tuscan Buttes. The Tuscan Buttes are hornblende andesite domes erupted onto the underlying Tuscan Formation (Helley and Harwood, 1985; Lydon, 1967). They are the northernmost of at least 34 unusual domes, lava flows, and shallow intrusions emplaced into and on top of the Tuscan Formation. See discussion at Stop C-2. 0.8

10.3 Straight stretch headed towards Black Butte. 0.8

11.1 As highway curves to right, one gets an excellent view of the Cascade Range (fig. 15). 0.2

11.3 Cross Palmer Gulch. Still on Tuscan Formation. 0.6

11.9 Cross Supan Gulch. 1.0

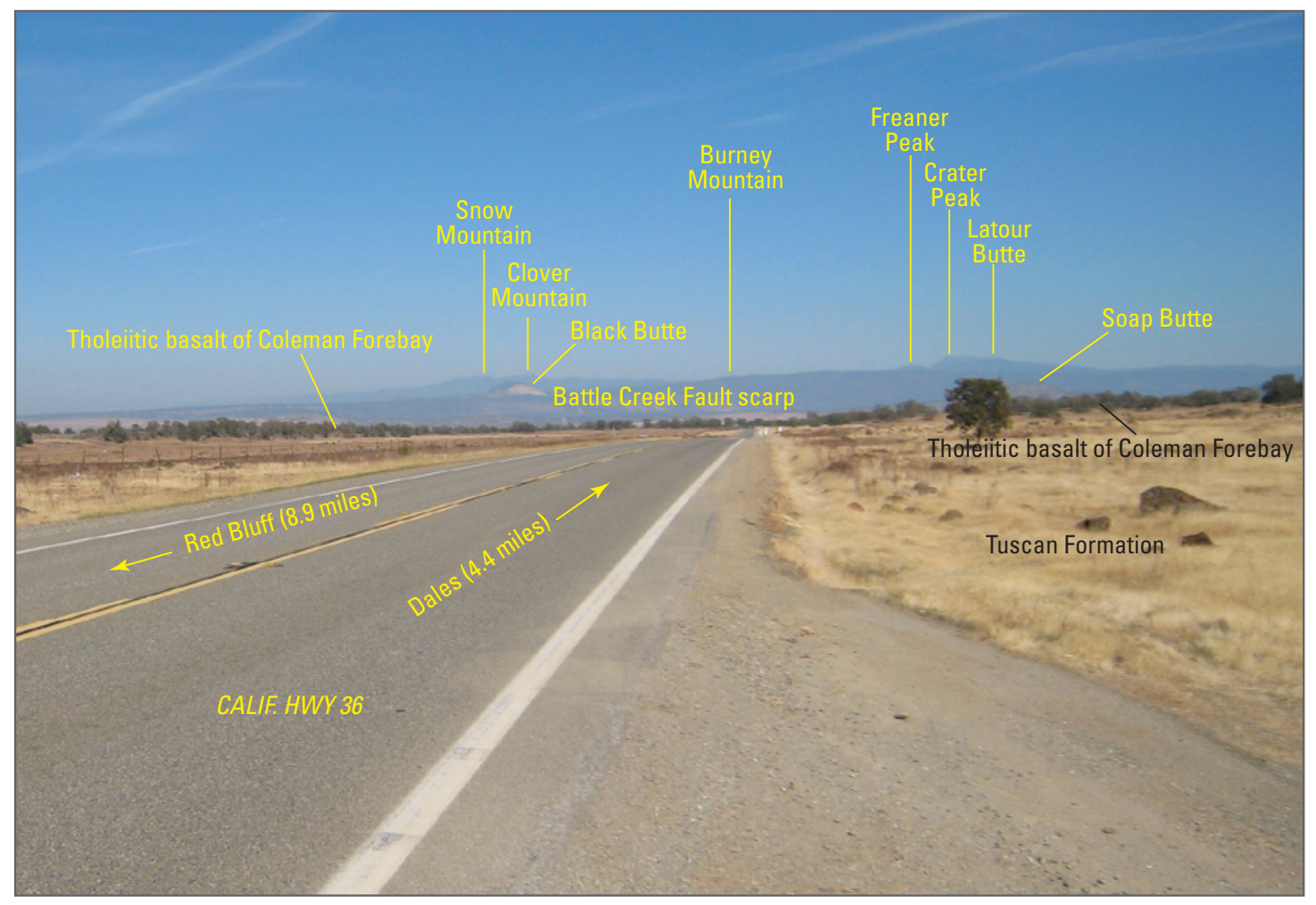

Figure 14. Photograph looking at azimuth $025^{\circ}$ from mile 8.9 on Calif. Hwy 36 between Red Bluff and Dales, showing features along the Battle Creek Fault scarp and the Cascade Range north of the Lassen Volcanic Center. The Tuscan Formation ( 3.5 to 2.5 Ma) in the foreground is overlain by the tholeiitic basalts of Coleman Forebay (950-750 ka). Extending across the photograph is the east-weststriking scarp of the Battle Creek Fault (down to the south). The tholeiitic basalts of Coleman Forebay and the tholeiitic basalt of Eagle Canyon (199 $\pm 22 \mathrm{ka}$ ) drape this fault scarp with minimal offset; basaltic andesite of Hootman Ranch ( $562 \pm 12$ ka) flows over the scarp and along its base with little offset. A flow from Black Butte, the $\sim 60$-ka cinder cone at the top of the scarp, is unfaulted. South of the fault scarp is Soap Butte, a 426 \pm 26 -ka calc-alkaline basalt (K-Ar date by G.B. Dalrymple, written commun., 1994). On the skyline are volcanoes of the Cascade axis: Burney Mountain $\left(280 \pm 6 \mathrm{ka} ;{ }^{40} \mathrm{Ar} /{ }^{39} \mathrm{Ar}\right.$ date by M.A. Lanphere, written commun., 1998), Freaner Peak, and Magee volcano $(210 \pm 120 \mathrm{ka}$; the highest point is Crater Peak). Between the Battle Creek Fault scarp and the Cascade axis lie the Snow Mountain Volcanic Center (>1.4 Ma) and the Latour Volcanic Center (>3.0 Ma), centered at Latour Butte. 
12.9 Cross Sheep Gulch. 0.4

13.3 The settlement of Dales and the intersection with Tehama County Road A16 to the left towards Manton; continue straight on Calif. Hwy 36. Brief views of Black Butte at 9:30, Soap Butte at 10:00, and Inskip Hill at 12:00. 2.9

16.2 Pass from Tuscan Formation onto basalt of Inskip Hill. 0.4

16.6 Cross Paynes Creek. 0.4

17.0 Good exposures of the basalt of Inskip Hill. Roadcuts for the next 5 miles alternate between Tuscan Formation and basaltic lava flows from Inskip Hill, a late Pleistocene shield volcano located to the west (trenchward) of the Cascade Arc. Flows from Inskip Hill fill present-day drainages and are estimated to be about 50 ka. $\mathbf{0 . 2}$

17.2 Pass back onto Tuscan Formation. 0.1

17.3 Boundary of Dales quadrangle and Inskip Hill quadrangle to the east. $\mathbf{0 . 2}$

17.5 Good views of Tuscan Formation at 12:00 to left of highway. 1.2
18.7 Pass from Tuscan Formation onto basalt of Inskip Hill. 0.3

19.0 Pass from basalt of Inskip Hill onto Tuscan Formation. 0.3

19.3 Pass from Tuscan Formation onto basalt of Inskip Hill. 0.1

19.4 Pass from basalt of Inskip Hill onto Tuscan Formation. 0.4

19.8 Stop A-1: Debris-avalanche deposit from Dittmar Volcanic Center. Pull off on broad turnout on right side of road; the debris avalanche is exposed in the roadcut directly opposite the turnout. Beware of high-speed vehicles, particularly trucks, when crossing the highway.

The debris-avalanche deposit consists of megablocks of various volcanic rock types in a matrix of broken material. Notable features are the heterogeneity of the matrix composition, the invasion of matrix material into fractures and joint surfaces of lava blocks, the jigsaw fit of some blocks, and features indicating laminar flow of matrix material beneath the megablocks at the base of the deposit.

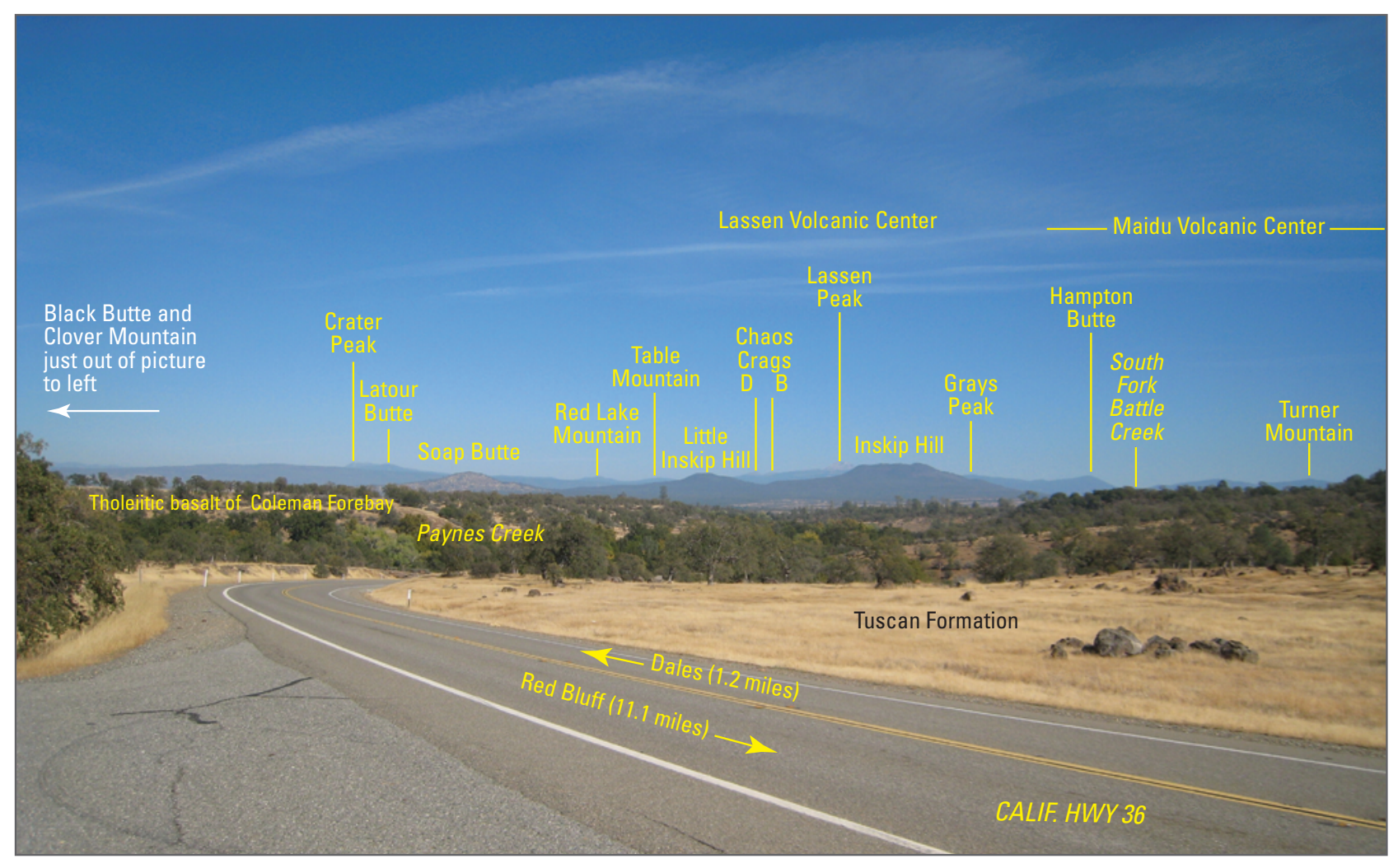

Figure 15. Photograph looking at azimuth $062^{\circ}$ from mile 11.1 on Calif. Hwy 36 between Red Bluff and Dales showing volcanic features of the southern Cascade Range. Foreground and banks of Paynes Creek are Tuscan Formation ( 3.5 to 2.5 Ma). At left-center, in front of the Battle Creek Fault scarp, is Soap Butte, a 426 \pm 26 -ka calc-alkaline basalt. At the right-center are Little Inskip Hill and Inskip Hill ( 50 ka); both are olivine basalt. Behind Soap Butte are Latour Butte in the Latour Volcanic Center (>3.0 Ma) and Crater Peak (summit of Magee Volcano; $210 \pm 120$ ka). Behind Little Inskip Hill and Inskip Hill are Chaos Crags domes B and D (1,103 \pm 13 B.P.; $~ 850$ C.E.) and Lassen Peak (27 \pm 1 ka), units in the Lassen Volcanic Center. Red Lake Mountain ( 75 ka), Table Mountain ( 700 ka), and Grays Peak $(1,080 \pm 26 \mathrm{ka})$ are andesite and basaltic andesite volcanoes of the regional calc-alkaline suite. Further to the right is the Maidu Volcanic Center (2.4-1.2 Ma), cut by the canyon of South Fork Battle Creek. 
The three most abundant rock types (dark-gray ash-flow tuff with black pumice and sporadic fragments of obsidian; light-gray ash-flow tuff; andesite rich in large green augite phenocrysts) can be traced to their source in the Dittmar Volcanic Center, approximately $30 \mathrm{mi}(48 \mathrm{~km})$ east. The age of this debris-avalanche deposit is poorly known. It postdates deposition of most of the Tuscan Formation in the Inskip Hill area but is probably older than most of the intervening Maidu Volcanic Center; it may be $\sim 2.4$ Ma. The uncertainties in interpretation of this exposure and its relationship to the Tuscan Formation illustrate the need for systematic mapping and petrologic study of the Tuscan Formation.

In the roadcut $150 \mathrm{~m}$ west, the megabreccia is underlain by an ash-flow tuff identical to the ash-flow tuff blocks in the megabreccia. Between the ash-flow tuff and the megabreccia is a discontinuous, poorly sorted, channel-filling alluvial deposit.

The roadcut $150 \mathrm{~m}$ east exposes thin olivine basalt flows from Inskip Hill, $1.7 \mathrm{mi}(2.7 \mathrm{~km})$ northeast. Vineyards to the south in the valley of Paynes Creek are on this basalt. 0.2

20.0 Pass from Tuscan Formation onto basalt of Inskip Hill. 2.1

22.1 To right is Plum Creek Road leading to the community of Paynes Creek. 0.3

22.4 Pass from basalt of Inskip Hill onto Tuscan Formation. 0.1

22.5 To left is Lanes Valley Road. 0.6

23.1 For the next 1.5 miles, Calif. Hwy 36 is on a wide bench of Tuscan Formation with excellent views (fig. 16). 1.5
24.6 Boundary of Inskip Hill quadrangle with Finley Butte quadrangle to the east. $\mathbf{1 . 4}$

26.0 Large roadcuts for the next 0.7 mile display chaotic breccias of the Tuscan Formation. 0.7

26.7 For the next 4 miles, the highway is on another wide bench of Tuscan Formation. 3.9

30.6 Battle Creek Vista Point. Burned trees are from the fire of August 2012. View of the Tuscan Formation overlain by the rhyolite of Blue Ridge ( 1.2 Ma), a single $15-\mathrm{km}^{3}$ flow from the Maidu Volcanic Center, Stage 3. This lava flow covers $75 \mathrm{~km}^{2}$ and averages $200 \mathrm{~m}$ thick. Similar huge flows form Lost Creek Plateau, Mill Creek Plateau, and North Stover Mountain on the eastern flank of the Maidu Volcanic Center. These rhyolite flows are the largest in the Cascade Range and are similar in size to the huge lava flows filling the Yellowstone caldera. 0.4

31.0 White deposits of Rockland tephra with orange soil are exposed in low roadcuts for the next 2.5 miles. Eruption of the Rockland tephra at $609 \pm 7 \mathrm{ka}$ produced a small caldera that has subsequently been filled by Brokeoff Volcano and younger products of the Lassen Volcanic Center. Bedrock beneath the veneer of Rockland tephra consists of andesites of the Maidu Volcanic Center, Stage 1. 0.3

31.3 Road to right leads to Ponderosa Sky Ranch. 0.8

32.1 Boundary of Finley Butte quadrangle with Lyonsville quadrangle to the east. $\mathbf{0 . 4}$

32.5 Pass from Rockland tephra onto andesites and dacites of the Maidu Volcanic Center, Stage 2. 0.5

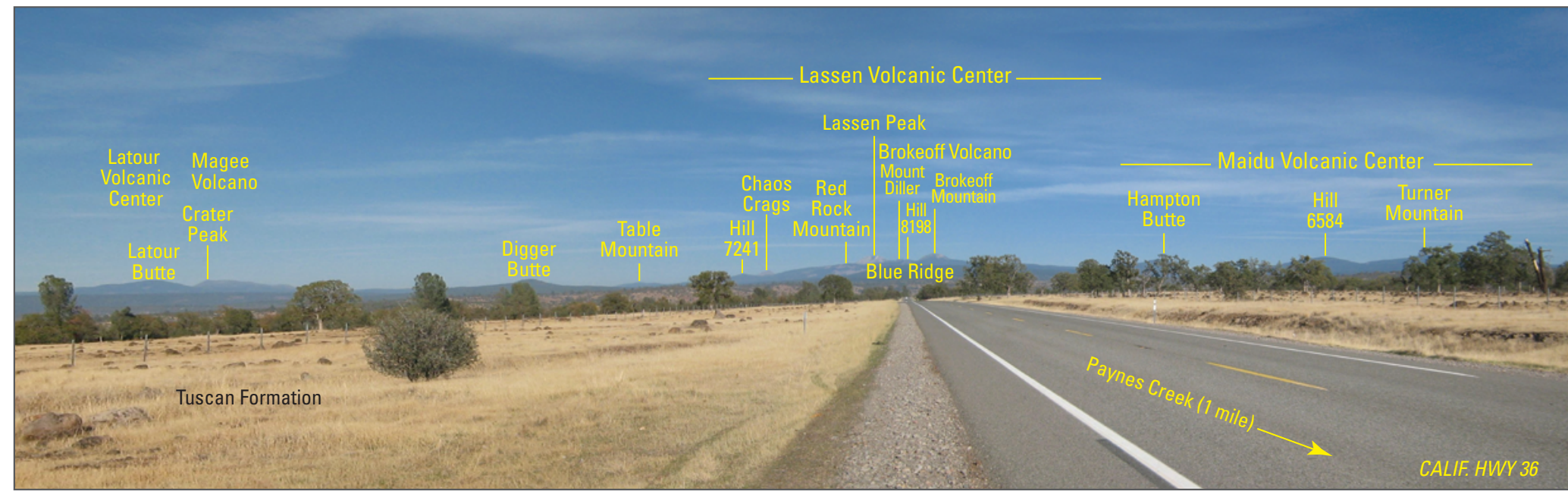

Figure 16. Panoramic photograph of volcanic features of the Lassen region taken at azimuth $060^{\circ}$ from mile 23.1 (E $\left.0593164, \mathrm{~N} 4465942\right)$ on Calif. Hwy 36 approximately 1 mile northeast of the turnoff to Paynes Creek. At the left are the Latour Volcanic Center (>3.0 Ma) and Magee Volcano $(210 \pm 120 \mathrm{ka})$. In the center are peaks of the Lassen Volcanic Center: hill 7241 (vent for the rhyodacite of Manzanita Chute; $297 \pm 1 \mathrm{ka}$ ), Chaos Crags (1,103 13 yr B.P.; 850 C.E.), the dome of Red Rock Mountain ( $672 \pm 20$ ka; part of the Rockland caldera complex), Lassen Peak (27 $\pm 1 \mathrm{ka})$, and three erosional remnants of Brokeoff Volcano (590-385 ka). Digger Butte and Table Mountain ( 700 ka) are, respectively, basaltic andesite and andesite volcanoes of the regional calc-alkaline suite. Farther to the right are peaks of the Maidu Volcanic Center (2.41.2 Ma). Blue Ridge (directly ahead along the road) is a giant $\left(15 \mathrm{~km}^{3}\right)$ rhyolite lava flow erupted at $\sim 1.2 \mathrm{Ma}$ as part of Stage 3 of the Maidu Volcanic Center. To the left (off the panorama) one can see Inskip Hill at 7:00, Black Butte at 8:30, and Mount Shasta in the far distance at 10:00. 
33.0 On right, Little Giant Mill Road to Lyonsville. Pass onto another patch of Rockland tephra. $\mathbf{0 . 4}$

33.4 Highway climbs onto a thick flow in andesites and dacites of the Maidu Volcanic Center, Stage 2. From here east to the town of Mineral, the highway traverses the northwest flank of the Maidu Volcanic Center, going downsection towards the core of the Maidu Volcanic Center near Mineral. 0.9

34.3 California Department of Forestry and Fire Protection (CDF) fire station on right. $\mathbf{0 . 1}$

34.4 Lassen Lodge on left. For the next mile, gaps between the trees give sporadic views of andesite and dacites of the Maidu Volcanic Center, Stage 2, on the north wall of the deep canyon of South Fork Battle Creek. 0.4

34.8 The highway passes from dacites of the Maidu Volcanic Center, Stage 2, downsection onto andesites of the Maidu Volcanic Center, Stage 1. 1.3

36.1 Roadcuts of andesitic flows and pyroclastic rocks on the flank of the Maidu Volcanic Center. 0.6

36.7 Road to left into the canyon of South Fork Battle Creek. Road to right (termed "A line") is the primary access to the Maidu Volcanic Center. Calif. Hwy 36 continues east on colluvium that is derived from the andesites of the Maidu Volcanic Center, Stage 1, to the south. A few poor exposures along the highway display the basalt of Cold Creek Butte (100-75 ka). This calc-alkaline flow extends $>5$ miles west down the canyon of the South Fork Battle Creek. 1.6

38.3 Quarry in the scoria cone of Cold Creek Butte. The layered internal structure of the scoria cone is exposed by the quarrying operation. Flows from this vent dammed South Fork Battle Creek to create Battle Creek Meadows to the east. $\mathbf{0 . 9}$

39.2 Bare rubble to the right is a basalt flow from Cold Creek Butte. 0.2

39.4 Boundary of Lyonsville quadrangle with Mineral quadrangle to the east. Cross South Fork Battle Creek into Battle Creek Meadows, the center of the hydrothermally altered and deeply eroded core of the andesitic composite cone of Maidu Volcanic Center; andesites of the composite cone are exposed in the cliffs north and south of the meadows. Maidu Volcanic Center was active from about 2.4 to $1.2 \mathrm{Ma}$ (fig. 7). To the left is U.S. Forest Service Road 17, which skirts the west side of the Lassen Volcanic Center to an intersection with Calif. Hwy 44 west of Manzanita Lake. 1.6

41.0 Intersection with Calif. Hwy 172 in the town of Mineral. Hwy 172 climbs southeast over the resistant rim of the andesitic composite cone of the Maidu Volcanic Center. Continue northeast on Calif. Hwy 36. 2.5

43.5 White roadcuts for the next two miles are in altered dacite of Christie Hill, one of several dacite domes emplaced at $\sim 800 \mathrm{ka}$ as part of the Rockland caldera complex of the Lassen Volcanic Center. 2.0

45.5 Turn left on Hwy 89 north to Lassen Volcanic National Park. Refer to road log through the park (Section D) and reset odometer to $\mathbf{0 . 0}$.

\section{Section B: Chester to Intersection of Calif. Hwys 36 and 89}

0.0 Intersection at Fire Station with Plumas County Road 318 to Juniper Lake and Road 312 to Warner Valley and Drakesbad, in the southeast corner of LVNP. A trail leads from the warm springs at Drakesbad through beautiful meadows and virgin forest to Boiling Springs Lake and Devils Kitchen, a high-temperature fumarolic area (Muffler and others, 1982, 1983).

Drive southwest along Calif. Hwy 36 towards Red Bluff. The highway is on outwash gravels of the younger glaciation $(35-17 \mathrm{ka}) . \mathbf{1 . 5}$

1.5 Chester Airport on left. 0.2

$1.7 \quad$ U.S. Forest Service Ranger Station on right. 0.6

2.3 Boundary of Chester quadrangle with Stover Mountain quadrangle to the west. $\mathbf{0 . 1}$

2.4 Cross Chester flood control channel, the diversion for the North Fork Feather River. 0.2

2.6 Highway 89 to left goes down the west side of Lake Almanor to Canyondam, traversing the tholeiitic basalt of Warner Valley $(610 \pm 22 \mathrm{ka})$ and the tholeiitic basalt of Rock Creek $(989 \pm 49 \mathrm{ka})$. These lithologically nearly identical basalts can most easily be distinguished by their different magnetic polarities (the tholeiitic basalt of Rock Creek has reversed polarity). The contact between the two units was mapped using a flux-gate magnetometer. $\mathbf{0 . 2}$

2.8 Calif. Hwys 36 and 89 climb up onto the tholeiitic basalt of Warner Valley (610 $\pm 22 \mathrm{ka})$. This large LKOT flow erupted from vents in vicinity of Mount Harkness in the southern part of LVNP and flowed southward at least 36 miles through the Lake Almanor Graben and into the canyon of the North Fork Feather River. 0.6

3.4 Contact between the tholeiitic basalt of Warner Valley and the basaltic andesite of Stover Mountain, a small shield volcano with a basal diameter of about 5 miles. Stover Mountain is typical of the regional calc-alkaline sequence. It consists of a 1,500-foot-thick sequence of sparsely porphyritic olivine basaltic andesite lava flows. The volcano is old and eroded, has no preserved vent areas, and is covered by a thick soil. Stover Mountain has a K-Ar age of 1,937 \pm 39 ka (M.A. Lanphere, written commun., 1997). 0.5

3.9 Roadcuts in the basaltic andesite of Stover Mountain. On the left for the next few miles, through the trees, one can glimpse andesites of the northern part of the Yana Volcanic Center (3.4-2.4 Ma). 5.0

8.9 Tehama County line. Highway passes onto the tholeiitic basalt of Ice Cave Mountain ( $\sim 65 \mathrm{ka})$. The vent for this young LKOT flow is 6 miles to the north at Ice Cave Mountain. The flow went south down the valley of Lost Creek to this point and then split into two lobes, one flowing southeast for another 3 miles to Soldier Meadows and the other flowing west for 
3.5 miles to Deer Creek Meadows. The tholeiitic basalt of Ice Cave Mountain overlies outwash gravel of the older glaciations ( $>130$ to $60 \mathrm{ka}$ ) and underlies outwash gravels of the younger glaciation (35-17 ka). 0.9

9.8 Saint Bernard. 0.1

9.9 Boundary of Stover Mountain quadrangle with Childs Meadow quadrangle to the west. $\mathbf{0 . 5}$

10.4 Roadcut in the distal toe of the rhyodacite of Gurnsey Creek ( 1.3 Ma). This thick lava flow of coarsely porphyritic augite-hypersthene rhyodacite erupted from a vent several miles to the northwest and flowed east from the east flank of Maidu Volcanic Center. $\mathbf{0 . 5}$

10.9 Deer Creek restaurant. The highway continues northwest along the contact between outwash gravels of the older glaciations to the north and the tholeiitic basalt of Ice Cave Mountain to the south. $\mathbf{2 . 0}$

12.9 At left is Calif. Hwy 32, which leads south along Deer Creek between the Yana Volcanic Center to the east and the Maidu Volcanic Center to the west (see Section C). Inconspicuous outcrops at the junction and along Gurnsey Creek $0.5 \mathrm{mi}$ west and south expose the Rockland tephra, part of the Rockland caldera complex of the Lassen Volcanic Center. The Rockland tephra was erupted at $609 \pm 7 \mathrm{ka}$ (Lanphere and others, 1999, 2004) from a small caldera now filled by younger rocks of the Lassen Volcanic Center (fig. 8). 0.3

13.2 View at 12:00 of the rhyolite of Lost Creek Plateau. For the next 7 miles to the north, the highway is in a broad valley cut in the rhyodacite of Gurnsey Creek (volume $\sim 2 \mathrm{~km}^{3}$ ). Overlying the rhyodacite of Gurnsey Creek on the right (east) is the rhyolite of Lost Creek Plateau $\left(\sim 5 \mathrm{~km}^{3} ; 1,305 \pm 10 \mathrm{ka}\right)$ and on the left (west) the rhyolite of Mill Creek Plateau $\left(\sim 7 \mathrm{~km}^{3}\right)$. These huge silicic flows, along with the rhyolite of North Stover Mountain $\left(\sim 8.5 \mathrm{~km}^{3}\right)$ and the rhyolite of Blue Ridge $\left(15 \mathrm{~km}^{3}\right)$, comprise the youngest part of the Maidu Volcanic Center and have an aggregate volume of $\sim 37 \mathrm{~km}^{3} .0 .6$

13.8 Bridge over Gurnsey Creek. To the left of the highway are exposures of one of the tholeiitic basalts of Mill Creek Plateau (140-100 ka). This basalt flow erupted from a vent 4 miles to the northwest, flowed northeast off the Mill Creek Plateau, and then south along Gurnsey Creek. Highway is on top of this flow for the next $1.3 \mathrm{mi} . \mathbf{0 . 8}$

14.6 Fire Mountain Lodge. $\mathbf{0 . 5}$

15.1 Bridge over Gurnsey Creek. Gurnsey Creek Campground to the right. In the bed of the creek just northwest of the bridge are outcrops of the tholeiitic basalts of Mill Creek Plateau. The valley of Gurnsey Creek for the next 5 miles is choked with glacial outwash and with colluvium from the friable rhyolite and rhyodacite flows that form the bluffs to the east and west. 1.1

16.2 View at 12:00 of the light-colored rhyolite of Mill Creek Plateau. 2.1

18.3 View at 11:30 of Brokeoff Mountain, part of the west rim of Brokeoff Volcano. This volcano ( $\sim 590-385 \mathrm{ka})$ is part of the Lassen Volcanic Center. $\mathbf{0 . 4}$
18.7 To the right is U.S. Forest Service Road 769 to Wilson Lake. 1.8

20.5 Stop B-1: Childs Meadows. Pull off on the right at the Childs Meadows Resort. View to the north up Mill Creek into the core of Brokeoff Volcano, composed of the Mill Canyon sequence (590-470 ka) of the Lassen Volcanic Center. The prominent peak in the left distance is Brokeoff Mountain (9,235 ft; 2,816 m), which forms the southwest rim of Brokeoff Volcano. Brokeoff Mountain consists primarily of the dacite of Twin Meadows $(470 \pm 10 \mathrm{ka})$, the uppermost unit of the Mill Canyon sequence. On the dip slope just to the left of the summit is the overlying andesite of Mount Diller ( $387 \pm 10 \mathrm{ka})$, one of six thick, large-volume, resistant lava flows that erupted from flank vents between 470 and $385 \mathrm{ka}$.

In the right distance is Mount Conard, which forms the southeast rim of Brokeoff Volcano. Mount Conard consists of flows and breccias of the Mill Canyon sequence. On the west flank of Mount Conard is the rhyodacite of Mount Conard $(298 \pm 9 \mathrm{ka})$, part of the Bumpass sequence of the Lassen domefield.

To the left of Mill Canyon in the middle ground is Morgan Mountain, one of several dacite domes emplaced at $\sim 800 \mathrm{ka}$ as part of the Rockland caldera complex of the Lassen Volcanic Center.

The cliffs to the east of Childs Meadows consist of the andesite of Wild Cattle Mountain ( 2.0-1.6 Ma), part of Stage 1 of the Dittmar Volcanic Center. The mountain south-southwest of Childs Meadows consists of the andesite of Doe Mountain (1.6-1.4 Ma; part of Stage 2 of the Dittmar Volcanic Center). 0.4

20.9 Highway passes through a small, geologically complex area containing andesites of Maidu Volcanic Center, Stage 1, the andesite of Doe Mountain, and a sliver of the andesite of Wild Cattle Mountain. 0.1

21.0 Boundary of Childs Meadow quadrangle with Mineral quadrangle to the west. $\mathbf{0 . 1}$

21.1 Cross Mill Creek. 2.5 miles to the north up Mill Creek on private land are Morgan Hot Springs and Growler Hot Spring, both characterized by near-neutral-pH, chloride-bearing boiling water that deposits siliceous sinter and pyrite. These springs represent outflow from the deep, $240{ }^{\circ} \mathrm{C}$ hot-water reservoir beneath the vapordominated system that feeds the fumarole areas such as Sulphur Works and Bumpass Hell in Lassen Volcanic National Park (Muffler and others, 1982; Ingebritsen and Sorey, 1985; Clynne and others, 2003; Janik and McLaren, 2010; Clynne and others, 2012).

Mill Creek and Deer Creek are the two major remaining free-running, salmon-spawning streams flowing into the Sacramento Valley. 0.4

21.5 Junction with Calif. Hwy 172, which loops south to the community of Mill Creek and then northwest to rejoin Calif. Hwy 36 at the town of Mineral. West of the junction, Calif. Hwys 36 and 89 climb up the south flank of Morgan Mountain and cross onto a large patch 
of till of older glaciations (>130-60 ka). $\mathbf{1 . 9}$

23.4 Passing lane. $\mathbf{0 . 2}$

23.6 Pass from till of older glaciations onto the andesites of Maidu Volcanic Center, Stage 1 ( $\sim 2.4$ to $\sim 2.15 \mathrm{Ma}) . \mathbf{0 . 3}$

23.9 Pass onto white, hydrothermally altered dacites of the Maidu Volcanic Center, Stage $2(\sim 2.15$ to $\sim 2.05 \mathrm{Ma})$. This alteration was produced by a shallow fossil acid-sulfate magmatic-hydrothermal system (John and others, 2005). 0.8

24.7 Till of older glaciations. $\mathbf{0 . 2}$

24.9 Rest area at Morgan Summit (5,750 feet). $\mathbf{0 . 1}$

25.0 Intersection of Calif. Hwy 36 to Red Bluff and Calif. Hwy 89 north to Lassen Volcanic National Park. Refer to road log through the Park (Section D) and reset odometer to $\mathbf{0 . 0}$.

\section{Section C: Chico to Intersection of Calif. Hwy 32 with Calif. Hwys 36 and 89}

$0.0 \quad$ U.S. Hwy 99E at Calif. Hwy 32 in Chico. 0.8

0.8 Forest Avenue. $\mathbf{0 . 3}$

1.1 Stoplight at El Monte Avenue. $\mathbf{0 . 4}$

1.5 Stoplight at Bruce Road. Contact of Sacramento River deposits with Tuscan Formation to the east. $\mathbf{0 . 7}$

2.2 Chico city limit sign. $\mathbf{0 . 6}$

2.8 Roadcuts in Tuscan Formation. $\mathbf{0 . 5}$

3.3 Boundary of Chico quadrangle with Richardson Springs quadrangle to the north. Microwave tower north of highway. $\mathbf{0 . 3}$

3.6 Power line. $\mathbf{0 . 2}$

3.8 Boundary of Richardson Springs quadrangle with Paradise West quadrangle to the east. $\mathbf{0 . 3}$

4.1 Roadcuts in Tuscan Formation. $\mathbf{0 . 9}$

5.0 Humboldt Road to east. $\mathbf{2 . 1}$

7.1 View back to right at 5:00 of Sutter Buttes (geologic description in Hausback and others, 2011). For next 10 miles, Calif. Hwy 32 is on a narrow bench of Tuscan Formation rising gently to the north between Big Chico Creek to the west and Little Chico Creek to the east. $\mathbf{0 . 5}$

7.6 Stop C-1: View of Tuscan Formation in Big Chico Creek. Large pullout on left with excellent view west across Big Chico Creek. The creek is cut into the Tuscan Formation, a broad volcanic and volcaniclastic wedge of fragmental material emplaced on the west slope of the southernmost Cascade Range (Anderson, 1933; Lydon, 1968; Helley and others, 1981; Helley and Harwood, 1985). The Tuscan Formation ( $\sim 3.5$ to $\sim 2.5 \mathrm{Ma}$ ), consists primarily of volcanic debris flows (lahars), conglomerate, sandstone, and siltstone, with minor silicic ash-flow and air-fall tuffs and sparse basaltic to andesitic lava flows. For the next 20.7 miles, Calif. Hwy 32 is mostly on the Tuscan Formation. $\mathbf{0 . 2}$

7.8 Santos Road to east. $\mathbf{0 . 1}$

7.9 Small pullout on left with excellent view. $\mathbf{0 . 2}$
8.1 Good view at large pullout on the left. $\mathbf{1 . 3}$

9.4 Dirt road on left leads to some good views of Big Chico Creek. 1.4

10.8 Large pullout on left. One can walk down through trees and brush for view to west across Big Chico Creek. 0.5

11.3 Roadcuts in Tuscan Formation. $\mathbf{0 . 3}$

11.6 Historical marker for 14-Mile House. 2.1

13.7 Nopel Ave (main road to community of Forest Ranch). $\mathbf{0 . 2}$

13.9 Boundary of Paradise West quadrangle with Cohasset quadrangle to the north. $\mathbf{1 . 0}$

14.9 Schott Road. School to the right. 3.1

18.0 Platt Mountain Road. Forest Ranch CDF fire station on right. Good roadcuts in Tuscan Formation for next 0.5 mile. 3.3

21.3 Calaveras Formation in roadcut to left. The Calaveras Formation in this region consists of phyllite and metachert with discontinuous limestone beds and is Carboniferous in age (Hietanen, 1973). 0.6

21.9 Carpenter Ridge Road (130G to west; F-line to east). 1.0

22.9 Good roadcuts in Tuscan Formation. Deeply weathered red zone overlies fresher gray Tuscan Formation. 0.8

23.7 Boundary of Cohasset quadrangle with Devils Parade Ground quadrangle to the north. $\mathbf{2 . 2}$

25.9 Boundary of Devils Parade Ground quadrangle with Butte Meadows quadrangle to the east. Good roadcuts in Tuscan Formation. 0.8

26.7 Lomo on left. $\mathbf{0 . 1}$

26.8 Humboldt Road (U.S. Forest Service Road 27N43) to right leads to the community of Butte Meadows and then deep into the Yana Volcanic Center, ending at Lake Almanor. $\mathbf{0 . 3}$

27.1 Small pullout on left with good view to west over Tuscan Formation. 0.4

27.5 Highway is along contact of Tuscan Formation to the right and Calaveras Formation to the left. For the next 2.2 miles, the highway follows the eastern contact of a window into the Calaveras Formation in the valley of Big Chico Creek, just to the west. $\mathbf{0 . 3}$

27.8 Tuscan Formation on both sides of highway. Large roadcuts in Tuscan Formation for the next 0.5 mile. 0.5

28.3 Pass onto Calaveras Formation. Large roadcuts of Calaveras Formation for next 0.6 mile. 1.6

29.9 Leave north end of window of Calaveras Formation and pass onto Tuscan Formation. 1.0

30.9 Conspicuous road junction with road to right leading to campground at Soda Springs. $\mathbf{0 . 2}$

31.1 Pass from Tuscan Formation onto a dome composed of andesite of Barkley Mountain. Vent is above and to left. This dome is one of a series of andesite and basaltic andesite domes along a lineament trending $310^{\circ}$. The domes were emplaced into and on top of the Tuscan Formation at 1.6-1.4 Ma. See discussion at mile 38.2, Stop C-2. $\mathbf{0 . 5}$

31.6 Pass from andesite of Barkley Mountain back onto Tuscan Formation. 2.6 
34.2 Boundary of Butte Meadows quadrangle with Onion Butte quadrangle to the north. $\mathbf{0 . 2}$

34.4 Big Smoky Creek. 0.8

35.2 Transfer (an old place name). Pass from Tuscan Formation onto the basaltic andesite of Transfer, a regional calc-alkaline lava that flowed northwest for four miles from a vent $1.25 \mathrm{mi}$ to the east. A K-Ar date on the basaltic andesite of Transfer is $1,777 \pm 124 \mathrm{ka}$ (M.A. Lanphere, written commun., 1997). 1.8

37.0 Pass from basaltic andesite of Transfer onto Tuscan Formation; start descent into valley of Deer Creek. For the next 8 miles, there are many good roadcuts in massive volcanic breccias of the Tuscan Formation, proximal to its source in the Yana Volcanic Center to the east. 1.2

38.2 Stop C-2: Overlook of Deer Creek. Turnoff to left for views looking up and down Deer Creek (figs. 17 and 18).

This stop gives a good view of several of at least 34 dacite to basaltic andesite domes, lava flows, and shallow intrusions that were emplaced into and on top of the Tuscan Formation during the early Pleistocene. The features appear to fall on two lineaments. The northern lineament, trending $290^{\circ}$ and including Onion Butte (fig. 18), is composed primarily of hornblende dacites with $\mathrm{K}$-Ar dates by Marvin Lanphere (written commun., 1997) of 2,593 $\pm 29 \mathrm{ka}$ (Onion Butte itself), 2,570 $\pm 32 \mathrm{ka}$, and
$2,505 \pm 39 \mathrm{ka}$. The southern lineament, trending $310^{\circ}$ and including the andesites and basaltic andesites of Barkley Mountain (fig. 17), erupted about $1,600-1,400 \mathrm{ka}$ (K-Ar dates of 1,562 $\pm 50 \mathrm{ka}$ and $1,440 \pm 54$ ka by M.A. Lanphere, written commun., 1997). All 34 domes are nearly aphyric or sparsely porphyritic; most contain hornblende but lack plagioclase, in contrast to most rocks in the Lassen area or the Cascade Range.

Domes of the northern (Onion Butte) lineament have high $\mathrm{Sr}$ and $\mathrm{Sr} / \mathrm{Y}$ and MORB-like ${ }^{87} \mathrm{Sr} /{ }^{86} \mathrm{Sr}$ values (C.M. Stout, written commun., 2015), thus, they are adakitic and may be slab or lower-crustal melts.

Domes of the southern (Barkley Mountain) lineament have low $\mathrm{Fe} / \mathrm{O} * / \mathrm{MgO}$ and major incompatible-element abundances similar to basaltic rocks found in the forearc area, but with higher ${ }^{87} \mathrm{Sr} /{ }^{86} \mathrm{Sr}$ (C.M. Stout, written commun., 2015), which suggests that these domes are derived from a source different from the basaltic rocks or that the dome magmas have assimilated crust during differentiation.

The localization of chemically distinct domes of different ages on two lineaments suggests tectonic control. In the Lassen region, the tectonic stress regime is dominated by impingement of Basin and Range tectonism on the Cascade Arc, and faults and most vent alignments are approximately north-south.

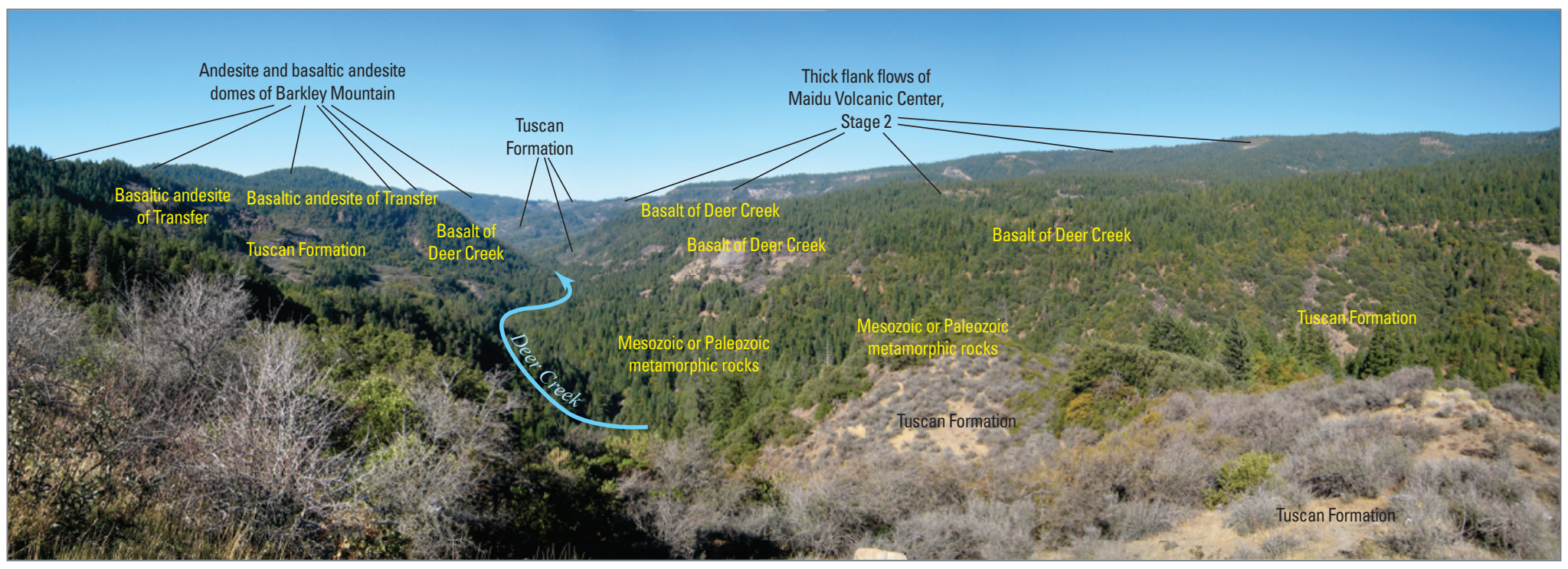

Figure 17. Panoramic photograph looking at azimuth $290^{\circ}$ down Deer Creek from viewpoint just west of Calif. Hwy 32 at mile 38.2 . Skyline to the north of Deer Creek consists of thick flank flows of Stage 2 of the Maidu Volcanic Center (2,150-2,050 ka). Skyline to the south of Deer Creek consists of domes of the andesite and basaltic andesite of Barkley Mountain (1,600-1,400 ka; see text), overlying the basaltic andesite of Transfer (1,777 \pm 124 ka; K-Ar date by M.A. Lanphere; written commun., 1997). All these units overlie the Tuscan Formation ( 3.5-2.5 Ma), which in turn rests unconformably on Paleozoic or Mesozoic metamorphic rocks (>65 Ma). Ancestral Deer Creek was filled at least three times by flows of tholeiitic basalt, at $\sim 1,800 \mathrm{ka}, 1,561 \pm 10 \mathrm{ka}\left({ }^{40} \mathrm{Ar} /{ }^{39} \mathrm{Ar}\right.$ age by P.R. Renne, written commun.), and 1,400 ka. At least one of these flows vented from the Onion Butte area (off the photograph to the right; see figure 18). Subsequent incision of Deer Creek has left benches of these basalts perched on both sides of the canyon. 
The lineaments here, however, are oriented at $\sim 60^{\circ}$ to the arc (approximately parallel to the southern edge of the subducted Gorda Plate), and their timing is broadly consistent with the passing of the Mendocino Triple Junction. In detail, however, such a control is not certain because the northern lineament is older than the southern lineament. Still, it seems likely that these rocks are somehow related to passage of the edge of the subducted Gorda Plate beneath the Lassen area. 1.1

39.3 Graded road up Cow Creek to the southeast provides access to the Yana Volcanic Center. 1.0

40.3 Bridge to west bank of Deer Creek. 1.7

42.0 Potato Patch Campground on right. 1.5

43.5 Deer Creek Falls. 0.6

44.1 Bridge to east bank of Deer Creek. 0.2

44.3 Boundary of Onion Butte quadrangle with Humboldt Peak quadrangle to the east. $\mathbf{0 . 4}$

44.7 Bridge to west bank of Deer Creek at Ladder Creek Campground. 0.4

45.1 Round Valley Creek on left. $\mathbf{0 . 2}$

45.3 Pass from Tuscan Formation onto flows and breccias of the Yana Volcanic Center, Stage 3. 2.5

47.8 On left is Slate Creek and its tributary to the north, Swamp Creek. 0.3 mi up creek, andesites of Maidu Volcanic Center, Stage 1, overlie a sequence of lithic pyroclastic flows, lithic and scoriaceous tephra, debris-flow deposits, and sediments. The sequence is intercalated between the Yana and Maidu Volcanic
Centers. $0.35 \mathrm{mi}$ further north up Swamp Creek are the valley-filling tholeiitic basalts of Mill Creek Plateau (140-100 ka), erupted from a vent at the summit of the plateau 3 miles to the north-northwest. 0.9

48.7 Entrance on left to Elam Creek Campground. For the next 1.3 miles, roadcuts on the right provide excellent exposures of the sequence of lithic pyroclastic flows, lithic and scoriaceous tephra, lahars, and sediments noted at mile 47.8. This sequence lies unconformably on dacites of the Yana Volcanic Center, Stage 3, and is overlain by andesitic lava flows of Maidu Volcanic Center, Stage 1. 0.1

48.8 Stop C-3: Volcaniclastic sequence at base of Maidu Volcanic Center. Elam Creek picnic area on left. Be very careful to watch for fast-moving trucks and cars. Walk north on the road to view a large roadcut of the lithic pyroclastic deposits noted above, here covered by a veneer of much younger gravel conglomerate deposited by ancestral Deer Creek. The highway for the next 2.3 miles to the north has very narrow shoulders with almost no opportunity for parking. Several roadcuts expose the volcaniclastic sequence overlain by an andesitic lava flow of the Maidu Volcanic Center, Stage 1. 0.2 Boundary between Humboldt Peak quadrangle and Childs Meadows quadrangle to the north. Small pullout on left with room for only a few cars. Be very careful to watch for fast-moving trucks and cars. Section

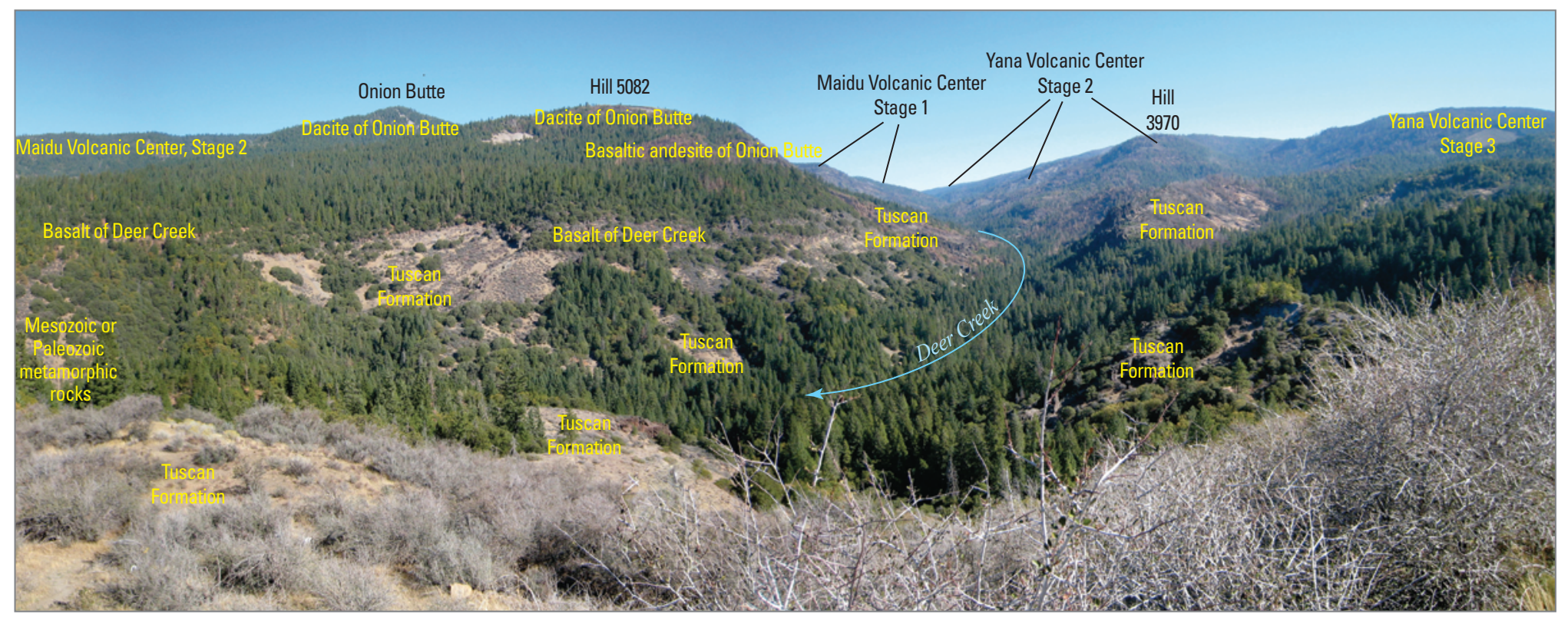

Figure 18. Panoramic photograph looking at azimuth $060^{\circ}$ up Deer Creek from viewpoint to west of Calif. Hwy 32 at mile 38.2 . Skyline to the left is dominated by domes of the dacite of Onion Butte $(2,600 \mathrm{ka})$, underlain by the basaltic andesite of Onion Butte, and overlain by andesitic flows of the Maidu Volcanic Center, Stage 2 (2,150-2,050 ka). All three units overlie the Tuscan Formation ( 3.5-2.5 Ma), exposed in the canyon of Deer Creek. Skyline in the center displays flows of Stage 1 of the Maidu Volcanic Center (2,400-2,150 ka; vents behind Onion Butte). Skyline on the right displays flows of Stage 2 and Stage 3 of the Yana Volcanic Center (3.4-2.4 Ma; vents out of picture to the right). 
exposed in roadcut on right consists of monolithologic scoria layers, lithic air-fall material, lahars, and a monolithologic lithic pyroclastic flow. The weathered top of the section is baked and reddened by the overlying andesitic lava flow from the Maidu Volcanic Center. The flow displays an excellent basal breccia overlain by a homogeneous core. 1.1

50.1 Bridge to west bank of Deer Creek. Bluff ahead at 12:00 to 3:00 consists of the rhyolite of the Mill Creek Plateau (1,300-1,200 ka), a thick, 7- $\mathrm{km}^{3}$ flow in the Maidu Volcanic Center, Stage 3. Forested slopes to the right (east) comprise dacites of the Yana Volcanic Center, Stage 3. 1.1

51.2 To left is main logging road to the west side of Deer Creek. 0.1

51.3 Bridge across Gurnsey Creek. $\mathbf{0 . 2}$

51.5 Low roadcut on left exposes the Rockland tephra, part of the Rockland caldera complex of the Lassen Volcanic Center. The Rockland tephra, a hypersthenehornblende rhyolite, was erupted at $609 \pm 7 \mathrm{ka}$ (Lanphere and others, 1999, 2004) from a small caldera now filled by younger rocks of the Lassen Volcanic Center (fig. 8). 0.1

51.6 Pass from Rockland tephra onto colluvium underlain by Rockland tephra. $\mathbf{0 . 5}$

$52.1 \quad$ Intersection of Calif. Hwy 32 with Calif. Hwy 36. Exposures of Rockland tephra. Turn left onto Calif. Hwy 32 and follow the road log of Section B from mile 12.4 to the intersection with Sections A and D at mile 24.5. Then reset odometer to 0.0 and follow Section D north through Lassen Volcanic National Park.

Figure 19. Photograph looking west at andesite flow exposed in the face of Bluff Falls quarry, just west of Calif. Hwy $89,0.8$ mile south of the south entrance to Lassen Volcanic National Park. The glacially carved cliff, modified by quarrying, exposes nearly the entire thickness of the andesite of Bluff Falls quarry $(467 \pm 10 \mathrm{ka})$, a typical silicic andesite flow from the Diller Sequence of Brokeoff Volcano. The base of the flow (not exposed here) consists of a thin, reddened, scoriaceous flow breccia that is overlain by a massively jointed, faintly flow-banded glass-rich zone. This zone grades upward into a thick zone of thin platy jointing. In the flow interior, platy jointing is nearly horizontal to slightly wavy, but at flow edges it can be ramped upward or highly contorted. On the glaciated flanks of Brokeoff Volcano, the orientation of platy jointing can be used to map flow edges and flow direction. The platy-jointed interior of the flow grades upward into a zone of crude columnar joints superimposed on the platy jointing. The upper surface of the flow is glassy and vesicular. The color change halfway up the cliff marks the base of the natural exposure. Large blocks at bottom of the photograph are $1-2 \mathrm{~m}$; cliff is $\sim 50 \mathrm{~m}$ high. Photograph 12 of Clynne and Muffler (2010).

\section{Section D: Intersection of Calif. Hwys 36 and 89 North Through Lassen Volcanic National Park to the Northwest Park Entrance}

Both Section A (from Red Bluff) and Section B (from Chester) end here. Follow Calif. Hwy 89 north towards Lassen Volcanic National Park. To the right for the next 1.4 miles is the dacite dome of Morgan Mountain, one of the dacite domes of the Rockland caldera complex. The valley to the left between Christie Hill and Morgan Mountain is filled by the basaltic andesite of Huckleberry Lake ( $300 \mathrm{ka})$, which erupted from a vent high on the flank of the extinct Brokeoff Volcano. This flow represents a return of the regional mafic volcanism after the extinction of Brokeoff Volcano about $385 \mathrm{ka}$. 0.6 Boundary of Mineral quadrangle with Lassen Peak quadrangle to the north. $\mathbf{1 . 7}$

2.3 Roadcut to left exposes till of Anklin Meadows ( 25-17 ka). See "Introduction" and figure 7 for glacial chronology. 1.6

3.9 Stop D-1: Bluff Falls quarry (fig. 19). To visit this quarry, park on right, walk $300 \mathrm{ft}$ north, cross the highway carefully, and climb up the slope just north of the small stream.

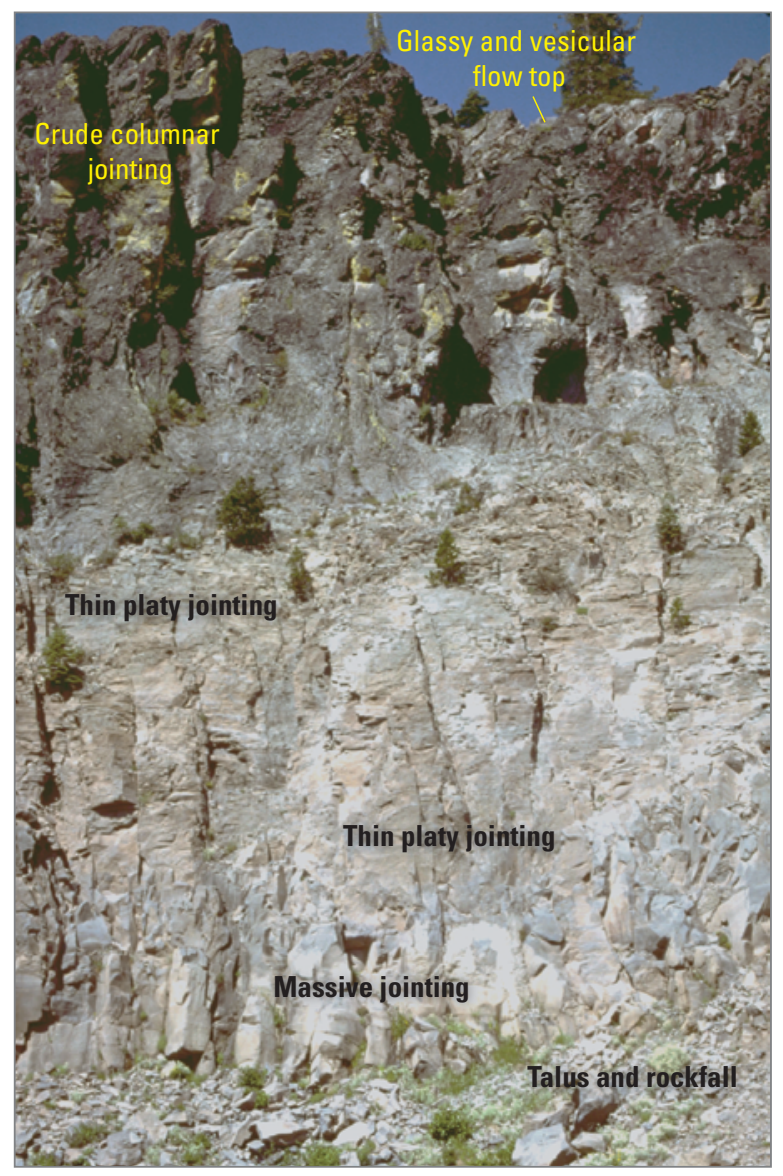


This glacially carved cliff exposes nearly the entire thickness of the andesite of Bluff Falls quarry ( $467 \pm 10 \mathrm{ka})$, a typical andesite lava flow of the Diller Sequence of Brokeoff Volcano. The upper part of Brokeoff Volcano, called the Diller Sequence (470$385 \mathrm{ka}$ ), is composed of six thick, laterally extensive lava flows, generally lacking intercalated fragmental deposits. Although different in detail, each unit of the Diller Sequence is a porphyritic augite-hypersthene andesite containing about $30-40$ percent phenocrysts, dominantly plagioclase, and is difficult to distinguish from other units of the Diller Sequence. Sparse olivine is commonly present and xenocrystic amphibole rarely so. Flows of the Diller Sequence are characterized by abundant $\mathrm{mm}$ - to $\mathrm{cm}$-size glomeroporphyritic clots of the phenocryst minerals, but with slightly different compositions. The clots commonly display solid-state recrystallization of orthopyroxene from olivine as well as exsolution features in pyroxenes; the clots have been interpreted as cognate crystals derived from cumulates (Clynne, 1990). Larger inclusions with gabbroic bulk compositions are sparse, and quenched magmatic inclusions like those in Lassen domefield rocks are rare.

The major-element compositions of lavas in the Diller Sequence range from about 58 to 63 percent $\mathrm{SiO}_{2}$ (fig. 9) and can be nicely modeled by crystal fractionation of average calc-alkaline basalt (Clynne,
1990) of the Lassen area. Incompatible trace-element abundances, however, increase much more rapidly in the models than they do in the lava suite, and addition of a high-silica component low in incompatible elements is required for the models to be viable. About 10 percent of a rhyolite melt remarkably similar to rhyolite lava flows found in the Lassen area satisfies this requirement. 1.6

5.5 Entrance station for Lassen Volcanic National Park. Just beyond is the Kohm Yah-mah-nee Visitor Center, with exhibits, gift shop, restaurant, and rest rooms. The entrance station and the visitor center are located on a large landslide that, $3,310 \pm 55$ years ago, moved $7 \mathrm{~km}$ down Mill Creek from the cliff at the base of Brokeoff Mountain. Reactivation of a small part of this landslide on January 2, 1997, temporarily blocked the park road just south of the entrance station. 1.0

6.5 Stop D-2: Sulphur Works. Turn left into the parking lot and walk east along Calif. Hwy 89. Sulphur Works is an area of fumaroles, boiling pools, mudpots, and steaming ground; it is the most accessible of the thermal areas in LVNP. Expansion of the thermal area has forced removal of a boardwalk that used to lead north across the thermal area. Visitors can, however, take the first 300 feet of the trail to Ridge Lakes for several good overlooks of the thermal area. Most of

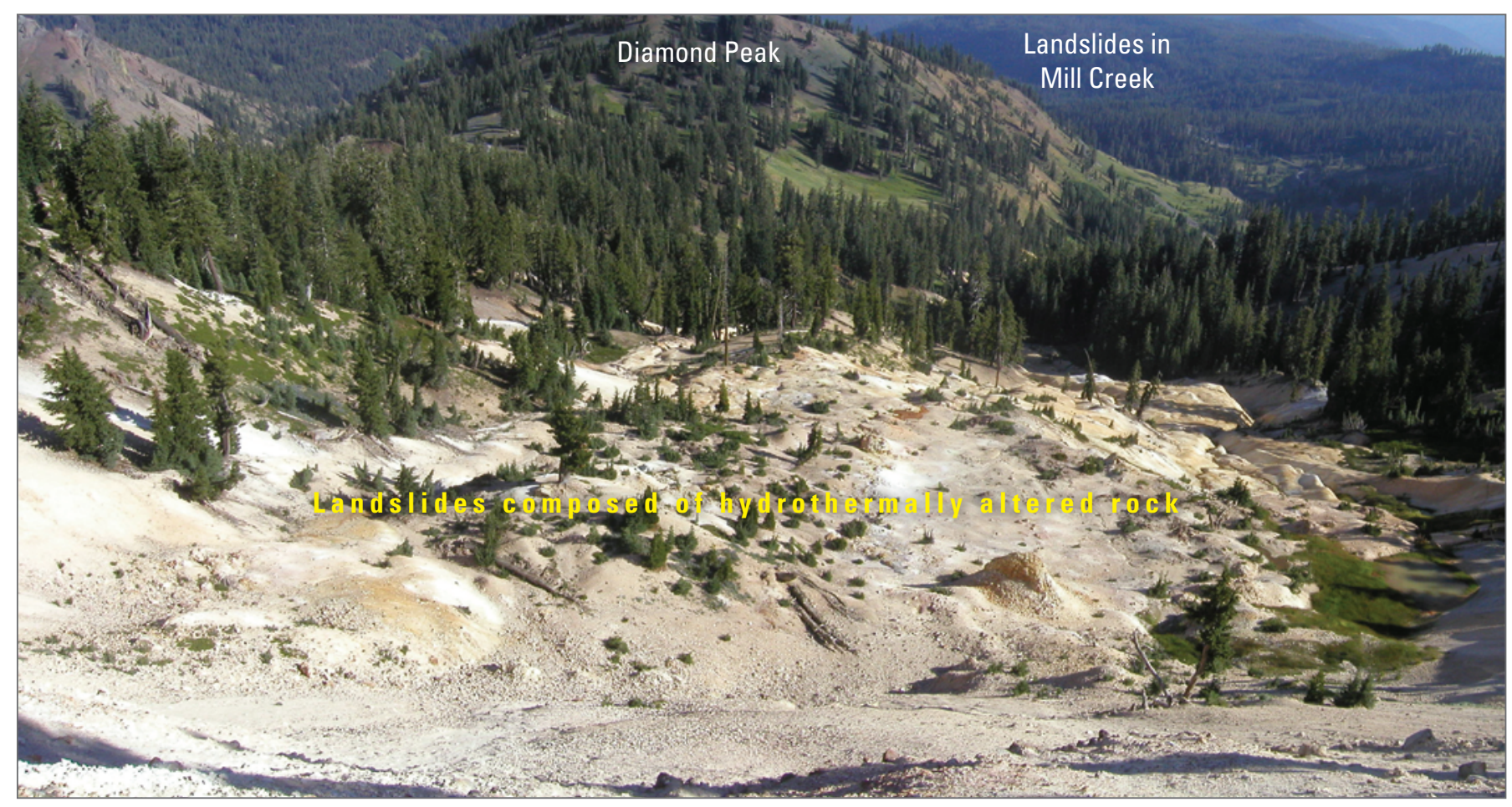

Figure 20. Photograph showing landslides in hydrothermally altered volcanic rocks. View looking southeast over active landslides in the area south of Pilot Pinnacle (off of the photograph to the left) and northwest of Diamond Peak. Most of the central area of Brokeoff Volcano is covered by these young landslides, which form in clay-rich, hydrothermally altered volcanic rock and are most active during the annual spring snowmelt. From figure 18 of Clynne and others (2012). 


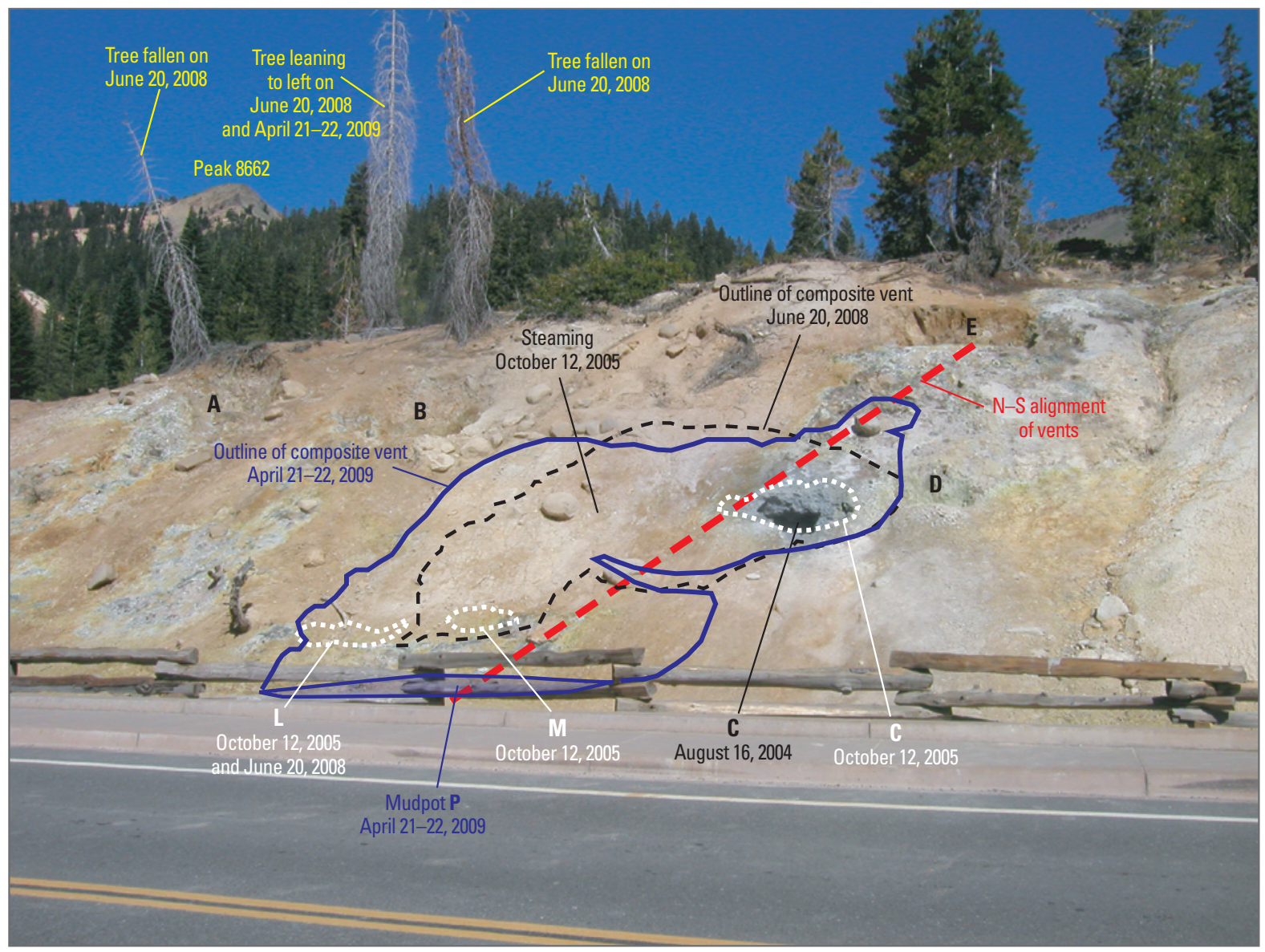

Figure 21. Annotated photograph showing changes of hydrothermal features at Sulphur Works from 2004 to 2005, 2008, and 2009. Photograph taken August 16, 2004, looking at $300^{\circ}$ azimuth across Calif. Hwy 89. Dotted white lines denote vents that were either enlarged $(C)$ or new ( $L$ and $M)$ as of 0 ctober 12, 2005. Short-dashed black line represents the boundary of the large vent resulting from the collapse of the area between vent $M$ and vent $C$, sometime between October 16, 2005, and June 20, 2008, probably in the winter of 2007-2008. Vents A, B, D, and E were essentially unchanged from August 2004 to June 2008. By April 2009, the large vent of 2008 had expanded further (solid blue line) and had developed into a vigorous mudpot just north of the fence and sidewalk (see fig. 22). Red dashed line represents north-south alignment of vents in 2009.

Figure 22. Photograph taken in November 2011 of mudpot $P$ (see fig. 21) north of Calif. Hwy 89 at Sulphur Works. The fence shown in figure 21 was just to the left of the curb at the lower right of the photograph.

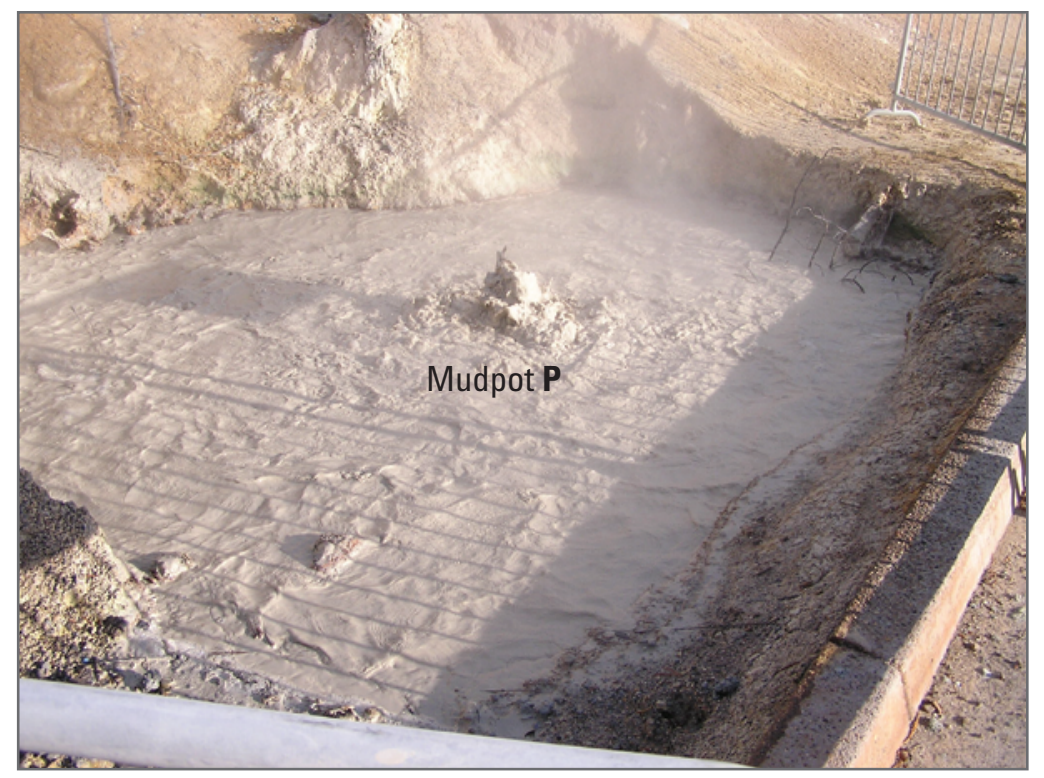


the area above Sulphur Works north to Mount Diller comprises dozens of old landslides of hydrothermally altered lava flows and pyroclastic rocks (fig. 20).

Temporal and spatial variation of fumaroles has been observed in all thermal areas of Lassen Volcanic Park, but it has been most systematically documented in recent years at Sulphur Works. From 2004 to 2011 (fig. 21), fumarolic activity north of Calif. Hwy 89 migrated south towards the road and became concentrated in a large boiling mudpot adjacent to the sidewalk curb (fig. 22). In addition, borings into the roadbed by the Federal Highway Administration in April 2009 and November 2011 demonstrated that boiling temperatures have risen to a depth of 15-20 ft (5-6 m) under Calif. Hwy 89, compromising the integrity of the roadbed. This situation led to extensive road repairs in the spring of 2013, the most recent of several road reconstructions across this treacherous area over the past 75 years. $\mathbf{1 . 4}$

7.9 Stop D-3: Diamond Peak. Pull far off the road into the parking area. Be careful crossing the road to examine the roadcut because visibility is restricted on this corner.
This viewpoint is near the center of Brokeoff Volcano. Virtually all the rocks that can be seen (fig. 23) are at least incipiently altered, and most areas in the core of the volcano are strongly to totally altered to propylitic and argillic assemblages related to fossil magmatic-hydrothermal systems at temperatures of 200 to $>300^{\circ} \mathrm{C}$ (Crowley and others, 2004; John and others, 2006). Unaltered rock is preserved only in dense, glassy, basal parts of lava flows. Flows and breccias on Diamond Peak dip steeply eastward, indicating that the summit vent of Brokeoff Volcano at the time of their eruption was nearby to the west. To the south, in the glacial valley of Mill Creek, the base of Brokeoff Volcano is exposed where it overlies rocks of Maidu Volcanic Center. Mill Canyon and the flanks of Brokeoff Mountain expose rocks representing nearly the complete history of Brokeoff Volcano. Thick flank flows of olivine-augite and hypersthene-augite andesite can be correlated across Mill Canyon with no offset by faulting. The triangle-shaped peak of Brokeoff Mountain to the west is resistant to erosion by virtue of the thick flow of pyroxene-hornblende

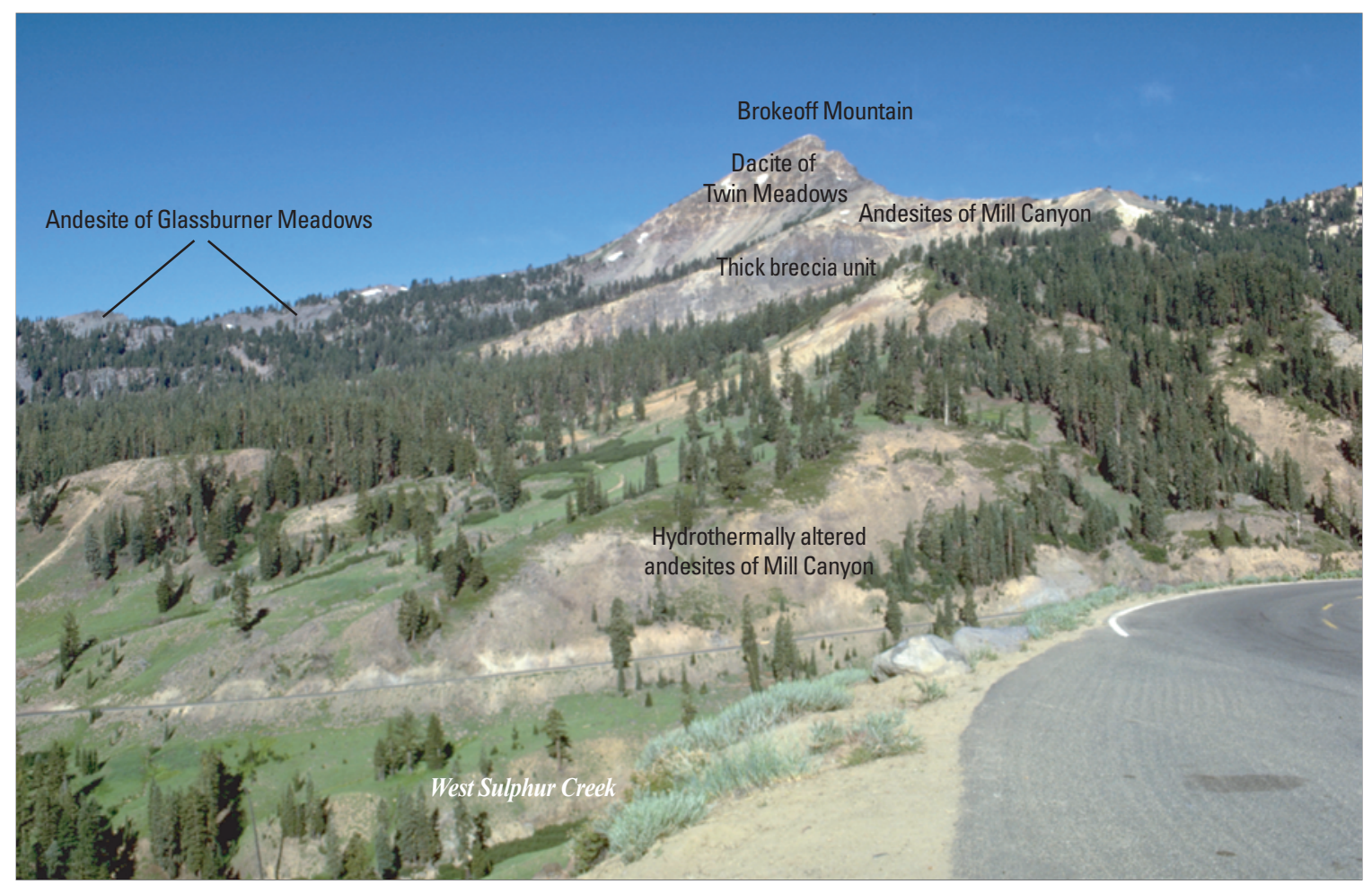

Figure 23. Photograph of Brokeoff Mountain looking west from turnout on Calif. Hwy 89 south-southwest of Diamond Peak, approximately at the center of Brokeoff Volcano. Foreground to middle ground consists of incipiently to strongly altered lava flows and fragmental deposits of the Mill Canyon sequence, with many postglacial $(<15 \mathrm{ka})$ landslides. Brokeoff Mountain forms the southwest rim of Brokeoff Volcano and consists primarily of the dacite of Twin Meadows $(470 \pm 10 \mathrm{ka})$, the uppermost unit of the Mill Canyon sequence. The overlying andesite of Mount Diller $(387 \pm 10 \mathrm{ka})$, part of the Diller sequence, crops out just beyond the summit of Brokeoff Mountain and is not visible in this photograph. The andesite of Glassburner Meadows ( 450 ka) is also part of the Diller sequence. Photograph 6 of Muffler and others (2010). 
dacite (the dacite of Twin Meadows; $470 \pm 10 \mathrm{ka}$ ) that ended the Mill Canyon sequence (590-470 ka). To the southeast, flows and breccias of the Mill Canyon sequence form most of Mount Conard. The cliff forming the prominent shoulder above Mill Canyon is a thick hornblende-biotite rhyodacite lava flow of the Bumpass sequence of the Lassen domefield. This flow followed the course of a canyon cut in rocks of the Mill Canyon sequence. The rhyodacite flow is dated at $298 \pm 9 \mathrm{ka}$ and illustrates the amount of erosion in the core of Brokeoff Volcano since that time.

The exposure in this roadcut is typical of the Mill Canyon sequence (590-470 ka), the lower part of Brokeoff Volcano. The Mill Canyon Sequence is composed of packages of thin lava flows and intercalated fragmental deposits, including agglomerates (like this exposure), breccias, and lahars. Adjacent packages of flows can have very different phenocryst abundances, phenocryst assemblages, and bulk composition. The lavas are mostly a diverse array of porphyritic andesites. Phenocryst assemblages are generally plagioclase-dominated and include combinations of olivine, augite, and hypersthene. Sparse porphyritic dacites have augite-hypersthene or hypersthene-hornblende assemblages. Abundant evidence for magma mixing includes resorption of phenocrysts, as well as reverse zoning, overgrowth rims, and compatible-element spikes in mafic phenocrysts. Small glomeroporphyritic clots of the phenocryst minerals are present in some Mill Canyon lavas, but are never as abundant as in the Diller Sequence. Larger inclusions with gabbroic bulk compositions are sparse, and quenched magmatic inclusions like those in Lassen domefield rocks are absent.

The major-element compositions of lavas of the Mill Canyon sequence range from about 54 to 68 percent $\mathrm{SiO}_{2}$ (fig. 4), although most are 5660 percent $\mathrm{SiO}_{2}$. As with the Diller Sequence, they can be nicely modeled by crystal fractionation of average Lassen area calc-alkaline basalt (Clynne, 1990) (see discussion at Stop D-1). The lavas and fragmental deposits of the Mill Canyon sequence evolved in a magmatic system that processed small increments of magma and thus erupted a diverse array of lithologies. Compared to the Mill Canyon Sequence, the largervolume eruptions, less heterogeneous lithologies, and less evidence for mineralogic disequilibrium argue that the Diller Sequence erupted from a magmatic system that was more mature and better integrated than during Mill Canyon time.

Pullouts over the next 2 miles provide excellent views of the east wall of Little Hot Springs Valley. Prominent are thin to thick lava flows of the andesites of Mill Canyon, part of the Mill Canyon sequence in the interior of Brokeoff Volcano. Permeable fragmental deposits are preferentially altered to light colors compared to the dark cores of lava flows. Overlying the andesites of Mill Canyon is the lessaltered andesite of Mount Diller (387 $\pm 10 \mathrm{ka}$, part of the Diller sequence). Steam vents and acid springs are abundant in landslide deposits along the floor of Little Hot Springs Valley. 2.6

10.5 White, kaolinite-rich altered andesite of the Mill Canyon sequence of Brokeoff Volcano at sharp bend in road. 0.6

11.1 Just before the south end of Emerald Lake, the road crosses the contact between the uppermost preserved rocks of Brokeoff Volcano and the augite-hornblende dacite dome of Ski Heil Peak (244 \pm 10 ka; part of the Bumpass sequence of the Lassen domefield). Straight ahead, Eagle Peak is a hornblende-biotite rhyodacite dome (66 4 ka; part of the Eagle Peak sequence of the Lassen domefield) that was preceded by a lava flow (the cliffs ringing the base of the dome) and a pyroclastic flow (which mantles Ski Heil Peak and is exposed distally just northwest of LVNP). 0.4

11.5 Stop D-4: Bumpass Hell parking lot. Walk out to the south end of the parking lot for excellent views of Brokeoff Volcano and the Bumpass and Eagle Peak sequences of the Lassen domefield. The parking lot is built on the contact between lava flows of the Diller sequence of Brokeoff Volcano and overlying dacites of the Bumpass sequence. Note the glacial striations and glacial boulders; the prominent 4-m boulder is hornblende-augite dacite from Bumpass Mountain.

To the south is the eroded core of Brokeoff Volcano, with the Maidu Volcanic Center in the distance. To the east is the hornblende-augite dacite of Bumpass Mountain (232 $\pm 8 \mathrm{ka}$ ). All the dacite domes of the Bumpass sequence have suffered extensive glacial erosion. Although the overall shapes of the domes have not been greatly modified, no trace of an outer glassy or pumiceous carapace or talus mantle is preserved. The view to the north is dominated by the glaciated dacite dome of Lassen Peak ( $27 \pm 1 \mathrm{ka}$; Turrin and others, 1998).

A gentle, level, 1.2-mi $(2 \mathrm{~km})$ trail winds southeast from the parking lot to Bumpass Hell, the major thermal area in this part of the park. The trail lies along the contact between the Diller sequence and the Bumpass sequence. Shortly after leaving the parking lot, one can see well-preserved glacial striae and polish on the massive dacite of Bumpass Mountain dome. The middle part of the trail has been blasted from the massively jointed devitrified interior of the dome. At the viewpoint where the trail turns east, $0.55 \mathrm{mi}(0.85 \mathrm{~km})$ from the parking lot, andesite of the Diller sequence is exposed, and a Park Service exhibit shows a model of Brokeoff Volcano before erosion. Farther along the trail, explosion breccia related to emplacement of the dacite of Bumpass Mountain is prominently exposed. 
Bumpass Hell (see photograph on page 1 of Clynne and others, 2003) marks a major thermal upflow ( $37 \pm 5$ megawatts; Sorey and Ingebritsen, 1995) of the Lassen geothermal system. Bumpass Hell is located at the vent for the dacite of Bumpass Mountain along the contact with the Diller sequence of Brokeoff Volcano.

Bumpass Hell contains numerous superheated fumaroles (Muffler and others, 1982), one of which had a temperature in the summer of 1988 of $161.4^{\circ} \mathrm{C}$ (Clynne and others, 2003). Boiling of the $240^{\circ} \mathrm{C}$ hot water in the reservoir provides the steam that feeds the surface features. Approximately 75 major fumaroles, acid-sulfate hot springs, and mudpots, plus myriad smaller features, occur in an area of approximately $0.13 \mathrm{~km}^{2}$ that is intensely altered to an aggregate of opal and kaolinite. Much of the surface of the active part of Bumpass Hell is covered with orange and yellow sulfates; many steam vents are lined with bright-yellow native sulfur. Pyrite is common as linings of the vents and discharge channels, as scum floating on the surface of pools, and as dispersions in gray or black mudpots.

The acid-sulfate water from Bumpass Hell is typical of hot springs related to a vapordominated reservoir in having low $\mathrm{pH}$, high sulfate concentrations, and no significant $\mathrm{Cl}$. Most other thermal areas in LVNP have thermal features and chemistry similar to Bumpass Hell and are also manifestations of the vapor-dominated reservoir. Some springs just below Sulphur Works (see photograph on page 4 of Clynne and others, 2003), in upper Little Hot Springs Valley, and at Drakesbad are relatively rich in $\mathrm{HCO}_{3}^{-}$(bicarbonate) and deposit travertine (calcium carbonate) or a mixture of silica and travertine. These springs are interpreted to be surface discharge from the zone of steam condensate that overlies the vapor-dominated reservoir (Muffler and others, 1982). 0.6

12.1 For the next 0.4 mile the road passes through the dacite of Mount Helen ( $249 \pm 12 \mathrm{ka})$, a lava dome of the Bumpass Sequence. This glaciated dome contains very abundant quenched mafic inclusions (Feeley and others, 2008b). See Stop D-6 (Chaos Crags) for a discussion of the origin and significance of quenched mafic inclusions. To the west is Lake Helen, a cirque lake of Anklin Meadows age (see fig. 11). 0.7

12.8 Lassen Peak parking lot. The large parking lot marks the start of an excellent trail that gains $1,950 \mathrm{ft}$ $(600 \mathrm{~m})$ in elevation as it switchbacks for $2.5 \mathrm{mi} \mathrm{(4}$ $\mathrm{km}$ ) to the summit of 27 \pm 1 -ka Lassen Peak (Eagle Peak sequence of the Lassen domefield) at 10,457 $\mathrm{ft}(3,187 \mathrm{~m})$. Although outer, pumiceous material has been removed by glaciation, Lassen Peak is still an impressively large dacite dome with a volume approaching $2 \mathrm{~km}^{3}$. The dacite of Lassen Peak has an unusual and distinctive phenocryst assemblage consisting of plagioclase, hornblende, biotite, quartz, augite, and olivine. The sparse augite and olivine were derived from disaggregation of the abundant quenched mafic inclusions in the dacite (see petrologic discussion of quenched mafic inclusions at Stop D-6). Paleomagnetic work by Duane Champion (Turrin and others, 1998) indicates that Lassen Peak was emplaced over a short period of time, perhaps as little as 5 years.

At the summit of Lassen Peak (fig. 24), one can observe the 1915-17 eruption craters and deposits (see 1:2,500-scale geologic map of the summit area in Christiansen and others, 2002) and on a clear day have good views of the Sierra Nevada, Sacramento Valley, Coast Ranges, Klamath Mountains, Mount Shasta, and the Medicine Lake Highlands. To the west of the parking lot is the hornblende-augite dacite dome of Lassen Peak parking lot (260-250 ka), part of the Bumpass sequence. Glacial erosion has exposed intricate flow banding in the margin of the dome. On the east side of the parking lot, a small tuff cone marks the vent for the hornblende-biotite rhyodacite lava flow and pyroclastic flows of Kings Creek ( $35 \pm 1 \mathrm{ka})$, part of the Eagle Peak sequence. $\mathbf{0 . 2}$

13.0 This pass at $8,511 \mathrm{ft}(2,594 \mathrm{~m})$ is the crest of the Cascade Range in this area. To the right is the glaciated biotitehornblende dacite dome of Mount Helen ( $249 \pm 12 \mathrm{ka}$ ), rich in quenched mafic inclusions. On the left is the dacite flow of Kings Creek. Much of the pumiceous glassy carapace and structure of the flow is preserved because it has not been heavily glaciated. Directly ahead, the next roadcut exposes thick breccia at the base of the flow. To the right beyond Mount Helen is the hornblende-augite dacite dome and flow complex of Bumpass Mountain (232 $\pm 8 \mathrm{ka})$ and a short stubby biotitehornblende dacite lava flow from Mount Helen. 0.05

13.05 Boundary of Lassen Peak quadrangle with Reading Peak quadrangle to the east. $\mathbf{0 . 6 5}$

13.7 View of Reading Peak, a deeply glaciated, dacite dome complex $(212 \pm 5 \mathrm{ka})$ of the Bumpass sequence. Before being eroded by glaciers, the Reading Peak complex was probably bigger than Lassen Peak. To the right and in the distance behind Reading Peak are Mount Harkness (a late Pleistocene basaltic andesite shield volcano), Kelly Mountain (a remnant of the 2.4-1.3 Ma Dittmar Volcanic Center), and Sifford Mountain, a basalt to basaltic andesite shield volcano $(172 \pm 23 \mathrm{ka}$ and $167 \pm 4 \mathrm{ka}$ ). Sifford Mountain is the southernmost young regional volcano in the Cascade arc and marks the approximate southern limit of active volcanism in the Lassen area. Over the past 2.5-3 m.y., the southern limit of active volcanism has migrated $27 \mathrm{~km}$ to the north from the vicinity of the Yana Volcanic Center (about $1 \mathrm{~cm} / \mathrm{yr}$ ). The broad flat plateau to the east of Sifford Mountain is a thick lava flow that is part of the dacite of Bumpass Mountain (232 \pm 8 ka). 0.7 
14.4 A set of linear cracks extends from here northwest across the Kings Creek lava flow, but cannot be traced into adjacent rock units. The en echelon segments define a zone of extension $1.1 \mathrm{~km}$ long. Segment widths range from a few meters to a few tens of meters, and there is no vertical offset. Opening took place after the Chaos Crags eruption at 1,103 \pm 13 B.P. ( $~ 850$ C.E.) and before the 1915 eruption of Lassen Peak. The most likely origin of the cracks is extension above a propagating dike that did not quite reach the surface. The cracks might be related to the 1915 eruption of Lassen Peak. 1.8

16.2 Excellent view of Lassen Peak at 12:00, Mount Helen at 10:30, and Bumpass Mountain at 9:30. The shoulder to the left of Bumpass Mountain is the Diller sequence of Brokeoff Volcano. Further to the left is Mount Conard, composed of andesites of the Mill Canyon sequence. $\mathbf{2 . 0}$

18.2 Cross Kings Creek. To the left is the $212 \pm 5$ ka dacite dome of Reading Peak. To the right is the large dacite flow $(232 \pm 8 \mathrm{ka})$ that vented at Bumpass Mountain.
The trail to Kings Creek Falls begins here and winds through delightful meadows and past beautiful cascades as Kings Creek descends through the thick dacite flow. Kings Creek Falls is just beneath the dacite flow, where the creek plunges over a thick lava flow of the augite-hypersthene andesite of Rice Creek (485 $\pm 12 \mathrm{ka}$ and $477 \pm 14 \mathrm{ka})$, part of the Diller Sequence of Brokeoff Volcano. $\mathbf{0 . 8}$

19.0 The skyline to the east, visible through the trees for the next 2.7 miles, is the Caribou Volcanic Field, an intensely glaciated area of over a hundred, mostly small, late Pleistocene basalt to andesite volcanoes. Volcanism in the Caribou Volcanic Field began at $\sim 425 \mathrm{ka}$ and was especially active from 400 to $300 \mathrm{ka}$ and from $110 \mathrm{ka}$ to the present. Conspicuous volcanic peaks in the Caribou Volcanic Field are Red Cinder, North Caribou, and South Caribou. 1.3

20.3 Elevation 7,000 ft (2,134 m). For the next 0.75 mile, volcanic vents of the Central Plateau are visible to the right through the trees. Rocks of the Central Plateau are all hybrid andesites of the Twin Lakes

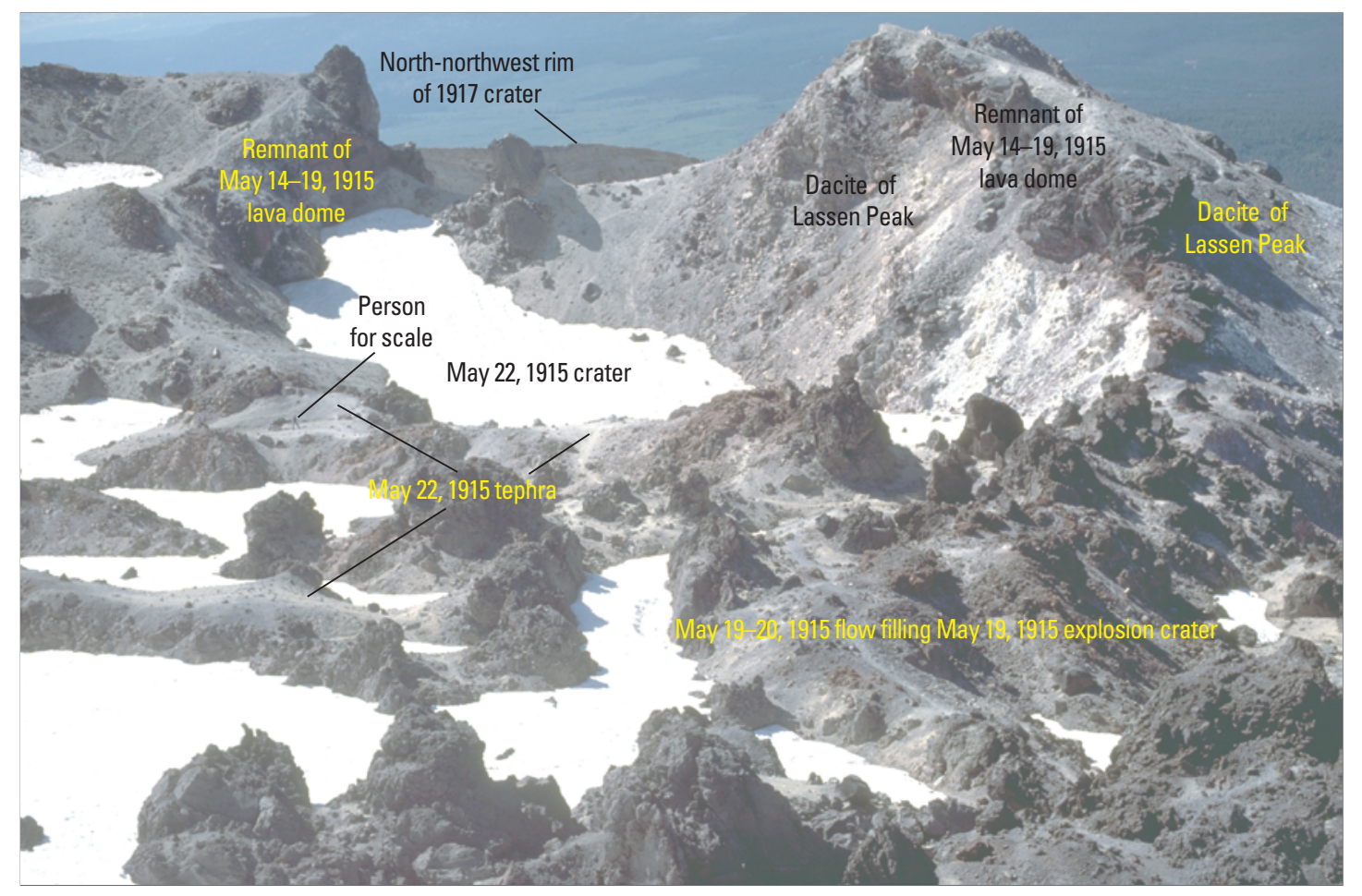

Figure 24. Photograph of the May 22, 1915, crater at the summit of Lassen Peak. View looking north-northwest from the summit of Lassen Peak at deposits from the summit eruption of 1914-1917 (Clynne and others, 2014; Christiansen and others, 2002). Black crags on left and right skyline are remnants of the dacite dome erupted May 14-19, 1915, filling the May 30, 1914-May 14, 1915, crater. Craggy area in the foreground to middle ground is the May 19-20, 1915, lava flow that filled the crater created when the lava dome was disrupted on the late evening of May 19, 1915. Crater (now snow-filled) in the middle to upper ground resulted from the pyroclastic eruption of May 22, 1915. Troughs (also snow-filled) in the lava flow resulted from partial slumping of the still-hot lava flow into the May 22 crater. Light-gray patches on the lava flow are tephra from the May 22, 1915, eruption. Gray walls of the May 22 crater are formed of weakly hydrothermally altered dacite of Lassen Peak ( $27 \pm 1 \mathrm{ka}$ ) and are partially covered by yellow sulfur deposits related to the 1915 eruption. Rim of crater formed by phreatic eruptions in 1917 visible on the center skyline. Modified from photograph 23 of Muffler and others (2010). 
sequence that erupted from vents on the periphery of the more central Bumpass and Eagle Peak sequences. The hybrid andesite magmas formed by mixing approximately equal amounts of dacite magma from beneath the domefield and calc-alkaline basaltic magma responsible for the regional volcanism. Hybrid andesite lava flows are thick, cover large areas, and are characterized by the coexistence of olivine and quartz. These rocks were called quartz basalts by Finch and Anderson (1930) and by Williams (1932). The two youngest volcanic events in Lassen Volcanic National Park, Cinder Cone (1666 C.E.) and the 1915 eruption at the summit of Lassen Peak, are hybrid andesites of the Twin Lakes sequence. At 12:00 is Hat Mountain, a 50-40 ka hybrid andesite. Most of the Central Plateau visible from here consists of the thick lava flows from Hat Mountain. Exposed along the road is monolithologic till derived from Reading Peak. 1.5

\subsection{Summit Lake. $\mathbf{0 . 5}$}

22.3 Ranger Station on East Fork Hat Creek. For the next 2.5 miles, the road passes through till of younger glaciations (35-17 ka) derived from Reading Peak, with sporadic outcrops of a $193 \pm 11$ ka lava flow, the dacite of Dersch Meadows, which is the youngest dacite of the Bumpass sequence. 1.5
23.8 Boundary of Reading Peak quadrangle with West Prospect Peak quadrangle to the north. 0.9

24.7 West Fork Hat Creek. 0.4

25.1 Stop D-5: Devastated Area parking lot. From the Devastated Area parking lot, first look southwest towards Lassen Peak. The May 1915 eruptions at the summit of Lassen Peak destroyed a 3- $\mathrm{mi}^{2}\left(8 \mathrm{~km}^{2}\right)$ area now called the Devastated Area (Clynne and others, 2014). The mature conifer forest that covered the area (fig. 25) was completely destroyed by the eruptions of May 1915 (figs. 26 and 27). Compare figure 27 with the vigorously growing trees that now cover the area.

Next, follow the gentle trail to the north of the parking lot to observe the deposits from the May 1915 eruptions. Note that the large "Hot Rock" in the Loomis photographs (figs. 26 and 27) can still be seen adjacent to the trail, but views of the Devastated Area are now obscured by trees.

Modern field and laboratory studies (Clynne, 1999; Christiansen and others, 2002) have produced a revised scenario of the May 1915 eruptions of Lassen Peak (fig. 28).

The eruptive sequence began on May 30, 1914, with a phreatic explosion at the top of Lassen Peak. By mid-May of 1915, more than 180 steam explosions

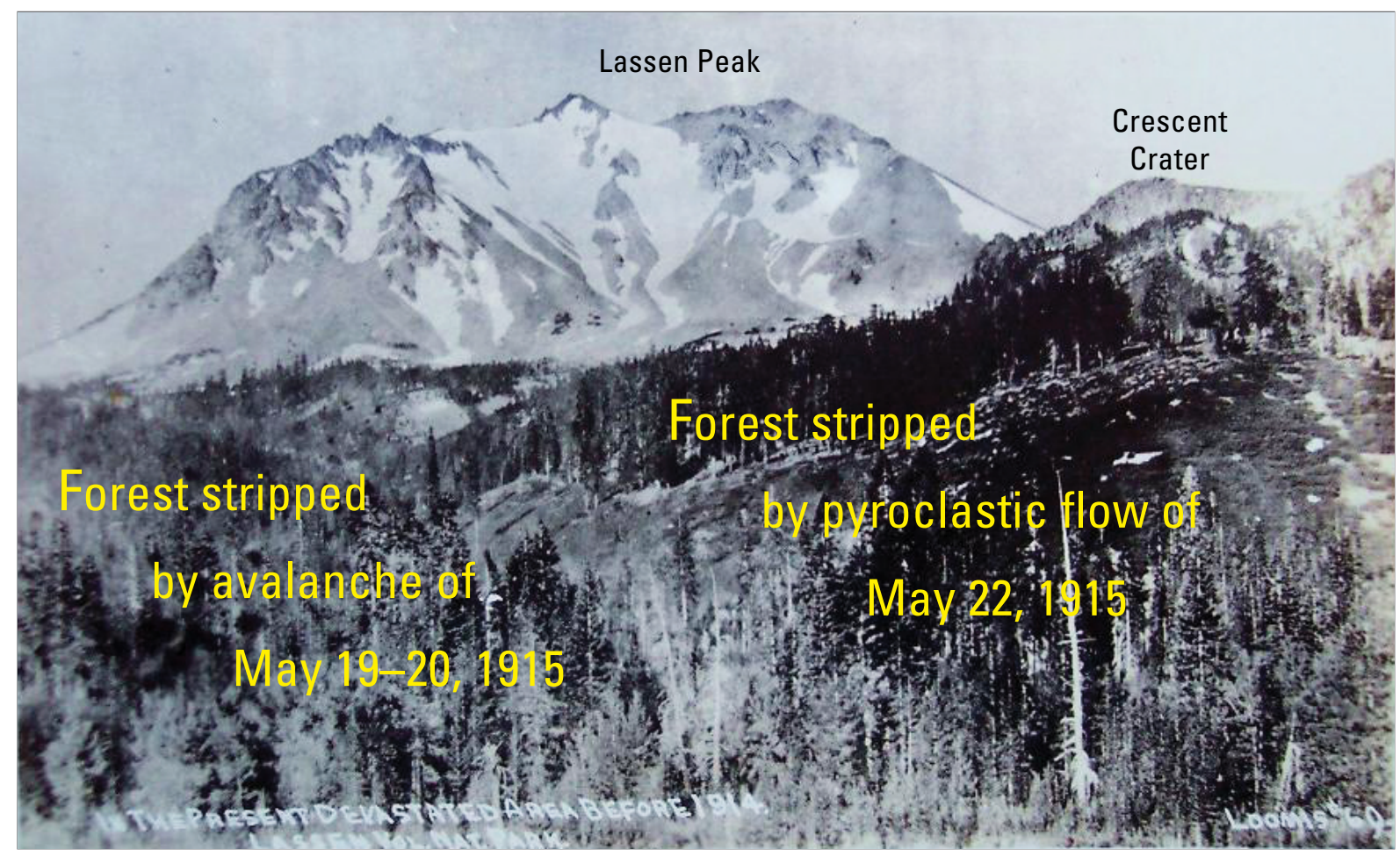

Figure 25. Photograph of the northeast flank of Lassen Peak taken by B.F. Loomis in June 1913, before the 1914-1917 eruption. The photograph looks southwest and shows the forest subsequently stripped by the eruptions of May 1915 (see fig. 26 and 27). Annotations by L.J.P. Muffler and M.A. Clynne. 


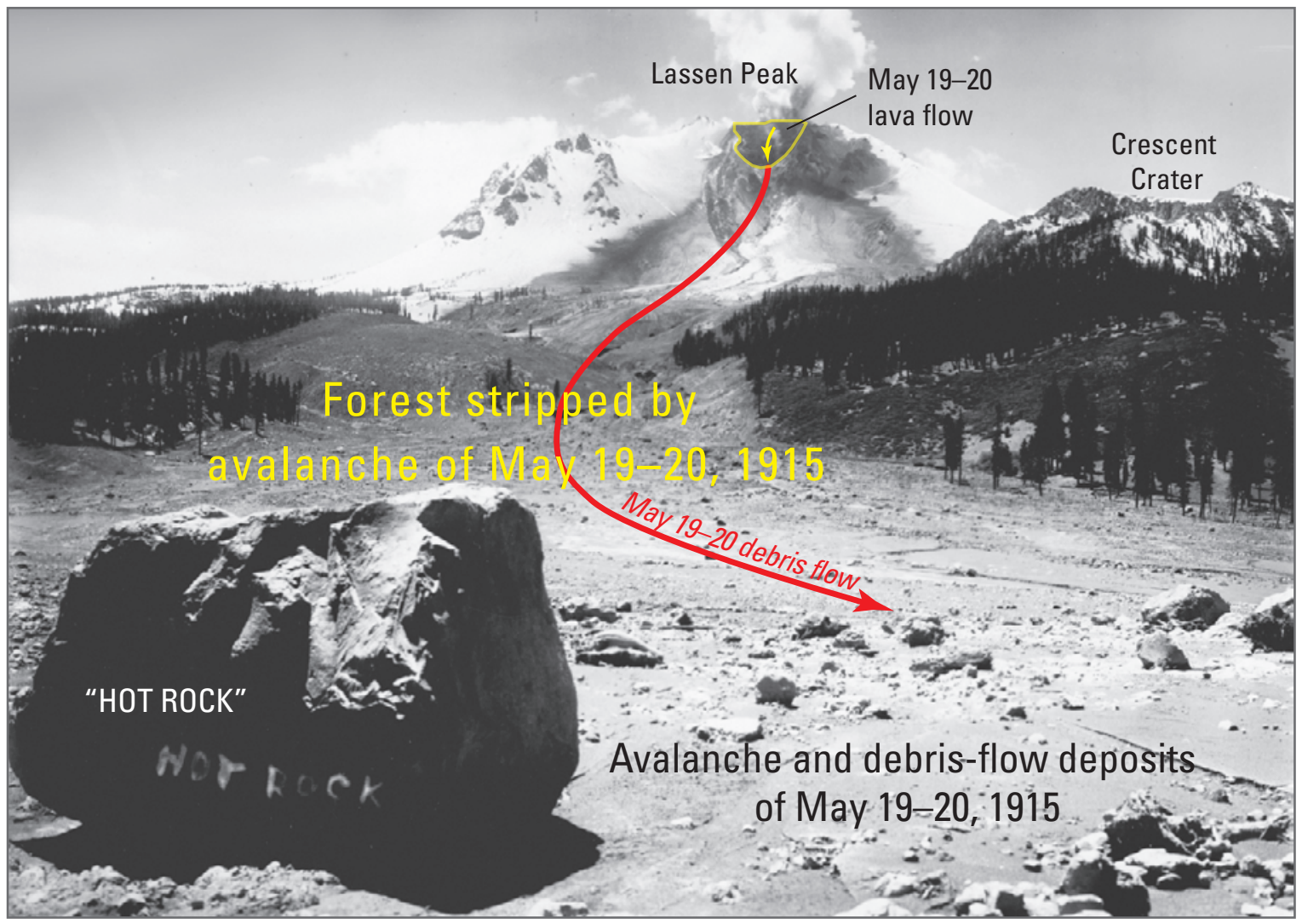

Figure 26. Photograph of the Devastated Area taken by B.F Loomis on the morning of May 22, 1915, before the Plinian eruption of 4:00 pm on May 22, 1915. The photograph shows the path of the avalanche and debris flow of May 19-20. Note that the northeast lobe of the May 19-20 lava flow at the summit of Lassen Peak is still in place. Annotations by L.J.P. Muffler and M.A. Clynne.

Figure 27. Photograph showing the Devastated Area after the eruption of May 22, 1915. Taken by B.F. Loomis in June 1915, the photograph shows the path of the pyroclastic flow produced by the Plinian eruption of $\sim$ 4:00 pm on May 22, 1915. Note the much wider zone of devastation compared to that of May 19-20 (fig. 26). Also, the May 19-20 lava flow high on the northeast flank of Lassen Peak is almost entirely gone. Annotations by L.J.P. Muffler and M.A. Clynne.

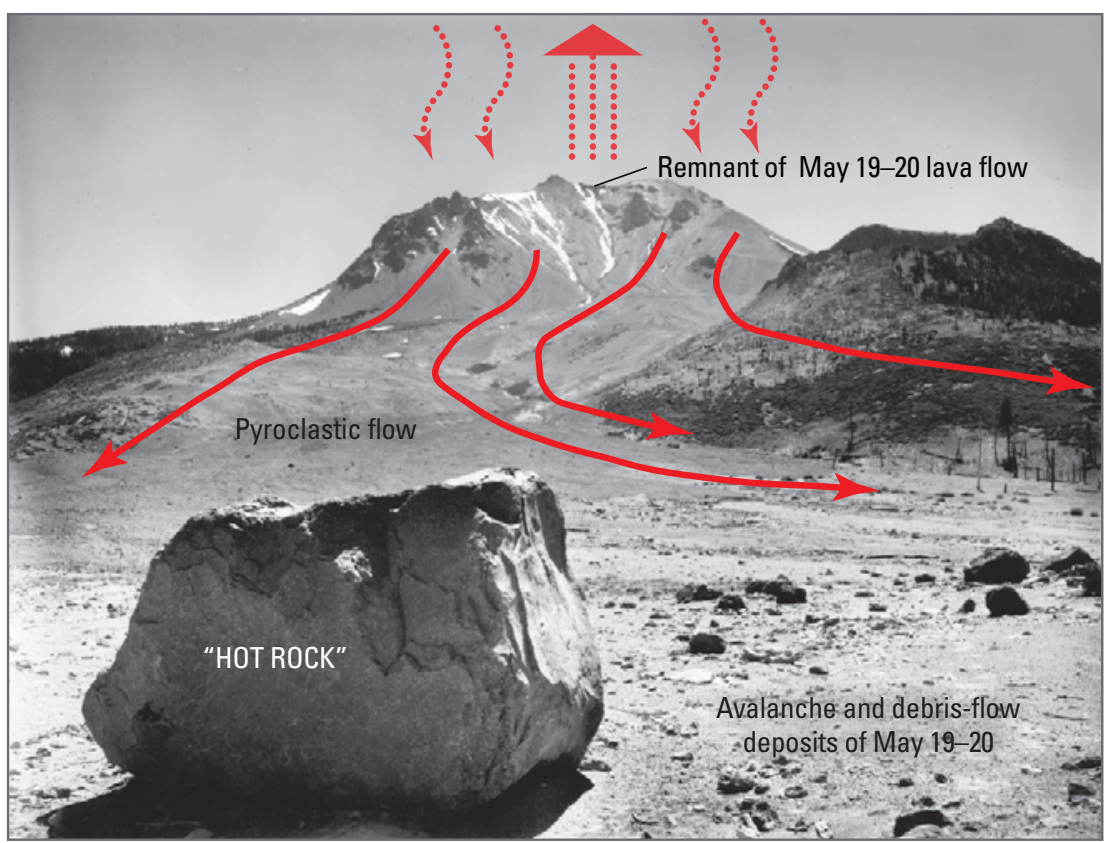


had blasted out a 300-m-long crater at the summit. In the week before May 19, 1915, a small dacite lava dome filled the crater. On the late evening of May 19, 1915 , the growing dacite dome was disrupted by a large explosion. Hot blocks of lava thrown onto the snow-covered upper flanks and summit of Lassen Peak initiated an avalanche of snow and rock that swept down the steep northeast face of Lassen Peak, over the low till ridge northeast of Emigrant Pass, and into Hat Creek (fig. 29). The avalanche was quickly followed by a debris flow generated by melting of snow by the hot dacite lava blocks and incorporation of underlying loose rock debris. The debris flow followed the same path as the avalanche until it encountered the low till ridge northeast of Emigrant Pass, where it was deflected west into Lost Creek, and flowed another $10 \mathrm{~km}$ to about $3 \mathrm{~km}$ west of Twin Bridges (the confluence of Hat and Lost Creeks). During the early morning hours of May 20, 1915, the debris-flow and avalanche deposits released large volumes of water that caused a flood along Hat Creek north of Old Station. Also in the late evening and early morning of May 19-20, 1915, dacite lava, which was less viscous than that erupted during the previous week, welled up into and filled the newly excavated crater. It spilled over two low spots on the rim and emplaced two short lava flows on the steep west and northeast flanks of Lassen Peak.

The eruptive sequence culminated two days later at approximately 4:00 p.m. on May 22, 1915. A vertically directed column of pumice and gas blasted through the May 19-20 lava flow, created a new crater, and rose to $30,000 \mathrm{ft} \mathrm{(6} \mathrm{mi;} 9 \mathrm{~km}$ ). Partial collapse of the eruption column initiated a pyroclastic flow on the northeast slope of Lassen Peak, which rapidly incorporated and melted snow in its path. By the time the pyroclastic flow reached the lower Devastated Area, it had transformed into a fluid debris flow that traveled down Lost Creek to Twin Bridges, where it released water and caused a second flood along Hat Creek north of Old Station. Fallout from the eruption cloud emplaced a pumice deposit on the upper slopes of Lassen Peak and a thin fallout lobe directed northeast towards Cinder Cone. Ash fall was recorded as far away as Elko, Nevada, 280 $\mathrm{mi}(450 \mathrm{~km})$ to the east. Pumice that fell on remaining snow-covered areas high on Lassen Peak generated six viscous debris flows that were emplaced on the west, north, and east flanks of Lassen Peak. The May 19-20 lava flow on the northeast flank of Lassen Peak was removed in this eruption and incorporated into May 22 deposits, and the still-hot lava at the summit partially slumped back into the May 22 crater (fig. 24). Only a small, dark fragment of this flow can be seen from the Devastated Area parking lot in the notch at the top of Lassen Peak (fig. 30). In contrast, the entire May 19-20 lava flow on the west flank of Lassen Peak can be seen today (fig. 31). 

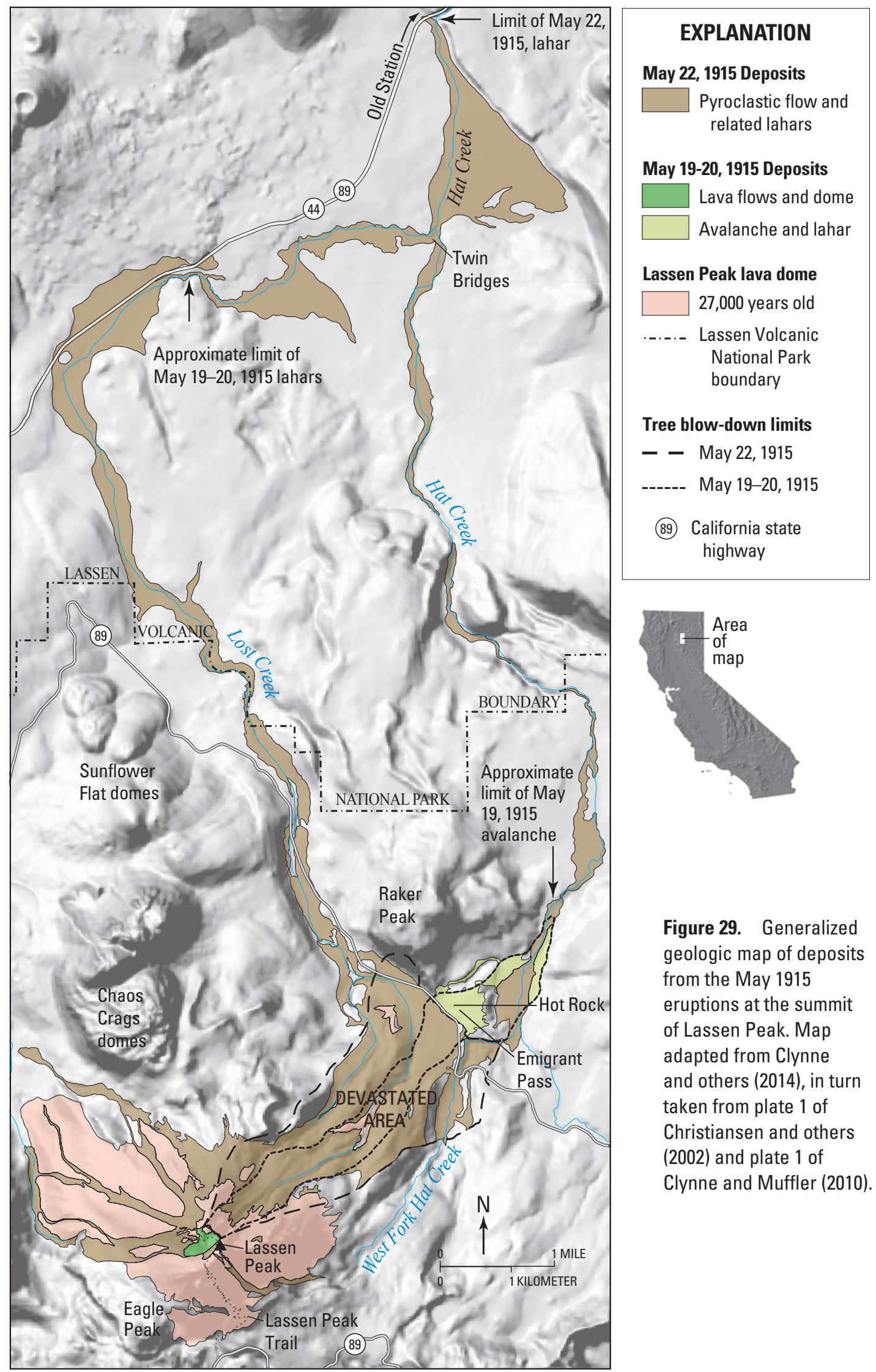

Figure 29. Generalized geologic map of deposits from the May 1915 eruptions at the summit of Lassen Peak. Map adapted from Clynne and others (2014), in turn taken from plate 1 of Christiansen and others (2002) and plate 1 of Clynne and Muffler (2010). 
For several years after the 1915 eruption, spring snowmelt percolating into Lassen Peak encountered hot rock and triggered steam explosions. Particularly vigorous phreatic explosions in May 1917 blasted out the northwestern of the two craters at the summit of Lassen Peak and emplaced phreatic deposits high on the west flank of Lassen Peak. The craters continued to emit substantial amounts of steam into the 1950s. Today, on cold days one can still find a few weakly steaming vents. Despite the widespread effects of the 1915 eruption, the total volume erupted was small, about $0.03 \mathrm{~km}^{3}$.

In the May 1915 eruptions, four types of volcanic rock were produced:

- a black dacite (64-65 percent $\mathrm{SiO}_{2}$ ) erupted as a lava dome between May 14 and 19 and as a lava flow (64-65 percent $\left.\mathrm{SiO}_{2}\right)$ emplaced on May 19-20 (fig. 32A)

- unbanded light-colored pumice (64-68 percent $\mathrm{SiO}_{2}$ ) erupted on May 22 (fig. 32B)
- compositionally banded pumice with dark (60-61 percent $\mathrm{SiO}_{2}$ ) and light bands (64-68 percent $\mathrm{SiO}_{2}$ ) erupted on May 22 (fig. 32C)

- quenched inclusions of andesitic magma (57-60 percent $\mathrm{SiO}_{2}$ ) that are abundant in the black lavas and sparse in the light pumice (fig. 32D).

The light bands in the banded pumice are generally compositionally equivalent to the black dacite, and the dark bands are compositionally equivalent to the quenched andesitic magma.

The 1915 rock types contain a complex mineral assemblage that indicates mixing between two compositionally distinct magmas: hornblende-biotite rhyodacite (approaching 70 percent $\mathrm{SiO}_{2}$ ) and olivine basaltic andesite $\left(\sim 54\right.$ percent $\left.\mathrm{SiO}_{2}\right)$. Each of the 1915 rock types is formed from different proportions of these two magmas through a complex series of interactions (Clynne, 1999). Intrusion of basaltic

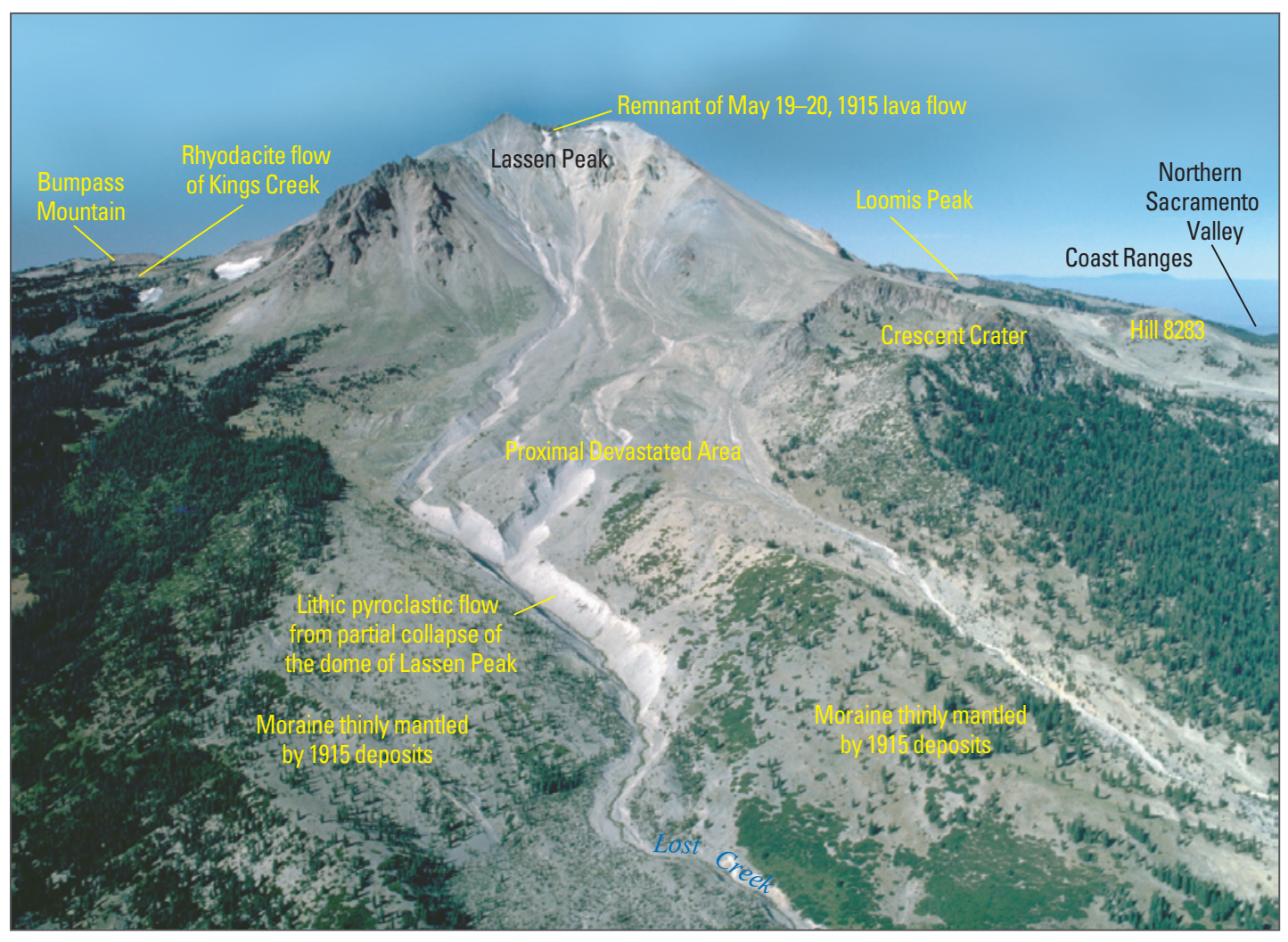

Figure 30. Low-angle oblique aerial photograph looking southwest at Lassen Peak and the proximal Devastated Area. Terrain with sparse trees marks the paths of avalanche and debris-flow deposits of May 19-20,1915, and pyroclastic-flow and fluid debris-flow deposits of May 22, 1915 (Clynne and others, 2014; Christiansen and others, 2002). Small dark crags just to right of the summit are remnants of the May 19-20, 1915, lava flow. The composite dacite dome of Lassen Peak (27 $\pm 1 \mathrm{ka})$ dominates the upper part of the view. Lithic pyroclastic-flow deposit from partial collapse of the dome of Lassen Peak is exposed in the canyon of the headwaters of Lost Creek in center of view. Ridges flanking central area are glacial moraines thinly covered by deposits of the 1915 eruption of Lassen Peak (Christiansen and others, 2002). A small permanent snowfield is seen on the left lower slope of Lassen Peak. Area to left of the snowfield is the rhyodacite lava flow of Kings Creek ( $35 \pm 1$ ka, part of the Eagle Peak sequence). Dacite domes of Bumpass Mountain (232 \pm 8 ka), Crescent Crater ( $236 \pm 1$ ka), hill 8283 $(261 \pm 5 \mathrm{ka})$ and Loomis Peak ( $300 \mathrm{ka}$ ) are part of the Bumpass sequence. Photograph 15 of Muffler and others (2010). 
andesite heated and mobilized rhyodacitic hornblendebiotite crystal mush. Formation and disaggregation of partially crystalline quenched inclusions of the hydridized basaltic andesite played a critical role in forming the array of compositions erupted. It is likely that the intrusion and magma-mixing event that produced these rock types also provoked the eruptions.

As one leaves the Devastated Area parking lot, the cliff ahead and to the right is the rhyolite of Raker Peak $(588 \pm 69 \mathrm{ka})$, a dome of the Rockland caldera complex. The front face of the dome is glaciated, exposing the internal flow structure of the dome. A much younger hybrid andesite volcano, Raker Peak (older Twin Lakes sequence), was built on top of the rhyolite dome at $270 \pm 18 \mathrm{ka}$.

For the next 1.8 miles, the road crosses 1915 debris flows, then a recessional moraine of the till of Anklin Meadows (25-17 ka), and then drops down onto the 1915 debris flows again. $\mathbf{1 . 4}$

26.5 To the left, 300 feet down a locked service road, the Lost Creek sand pit exposes the two lower pyroclastic flows of Chaos Crags. The sand pit also provides excellent views to the south of Lassen Peak (behind Crescent Crater), several highly glaciated domes of the Bumpass Sequence, and four of the six Chaos Crags domes (behind a large lateral moraine of the till of Anklin Meadows).

The Chaos Crags eruption at $1,103 \pm 13$ B.P. ( $\sim 850$ C.E.) is the third youngest eruption in Lassen Volcanic National Park. This eruption is typical of the type of volcanic activity to be expected in the Lassen domefield in the future. Detailed geologic mapping (Christiansen and others, 2002) has added significant new detail to the general stratigraphy of the Chaos Crags given by Crandell and others (1974). The Chaos Crags eruptive sequence consists of three pumiceous pyroclastic flows, six domes, and two dome-collapse lithic pyroclastic flows (fig. 33). The volume of the Chaos Crags deposits is approximately $1.2 \mathrm{~km}^{3}$, about 15 percent as pyroclastic flows (not including distal ash).

The initial event of the Chaos Crags eruptive sequence was the eruption of pumice and lithic debris and the formation of a tuff cone. Eruption of the lower and middle pyroclastic flows quickly followed. These were confined to the valleys of Lost and Manzanita Creeks, where they flowed to a distance of 5 $\mathrm{km}$. The most accessible exposures of these pyroclastic flows are at the Lost Creek sand pit. Whole tree trunks converted to charcoal are often found in the basal zone

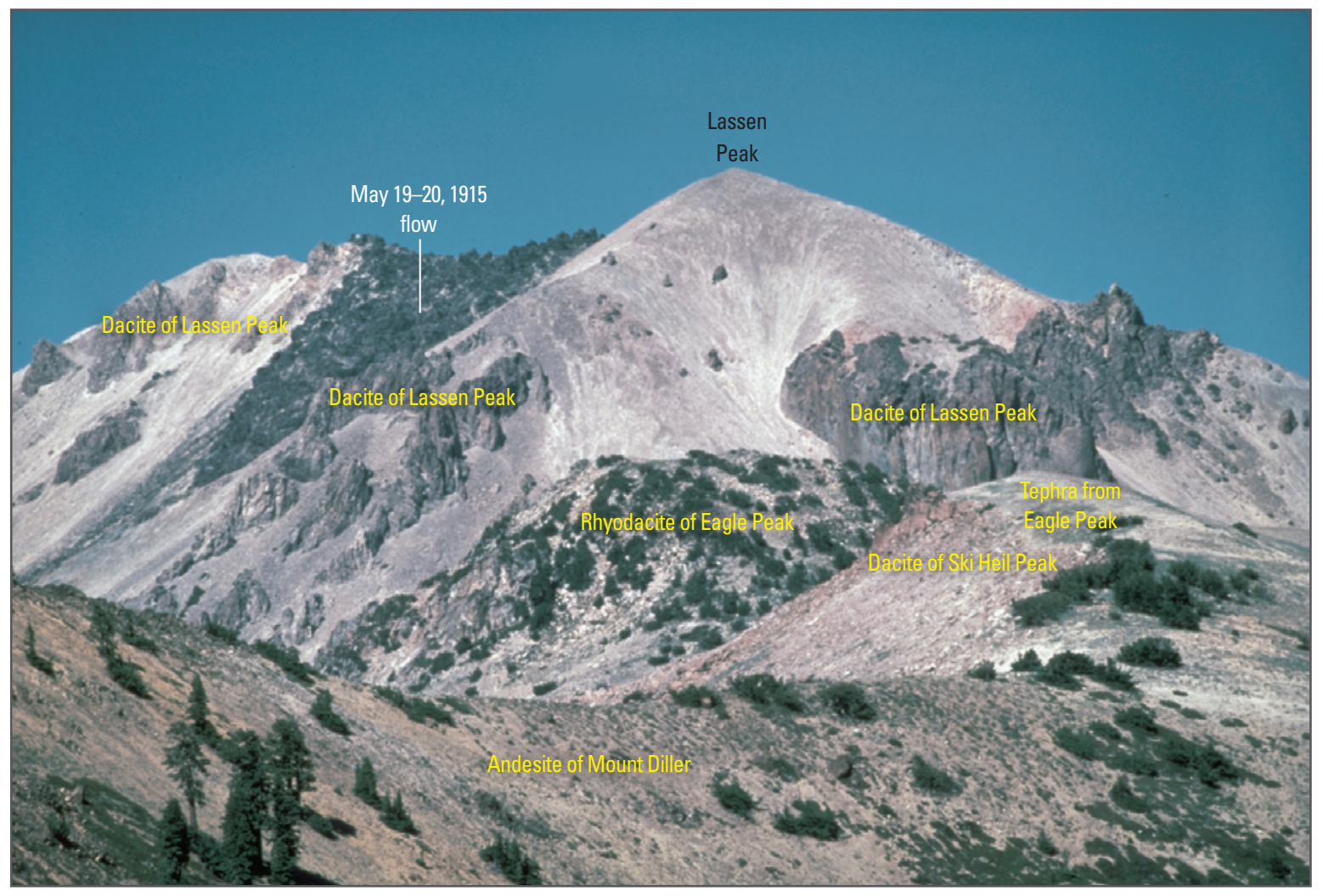

Figure 31. Telephoto view northeast from summit of Brokeoff Mountain looking at Lassen Peak ( $27 \pm 1 \mathrm{ka})$ and the west lobe of the dacite flow of May 19-20, 1915. The dacite dome of Eagle Peak (66 $\pm 4 \mathrm{ka}$ ) is part of the Eagle Peak sequence. The dacite dome of Ski Heil Peak ( $244 \pm 10 \mathrm{ka}$, part of the Bumpass sequence) is mantled by tephra from the eruption of Eagle Peak. Ridge in the foreground is composed of the altered andesite of Mount Diller (387 $\pm 10 \mathrm{ka}$ ), part of the Diller sequence of Brokeoff Volcano. Photograph 21 of Muffler and others (2010). 

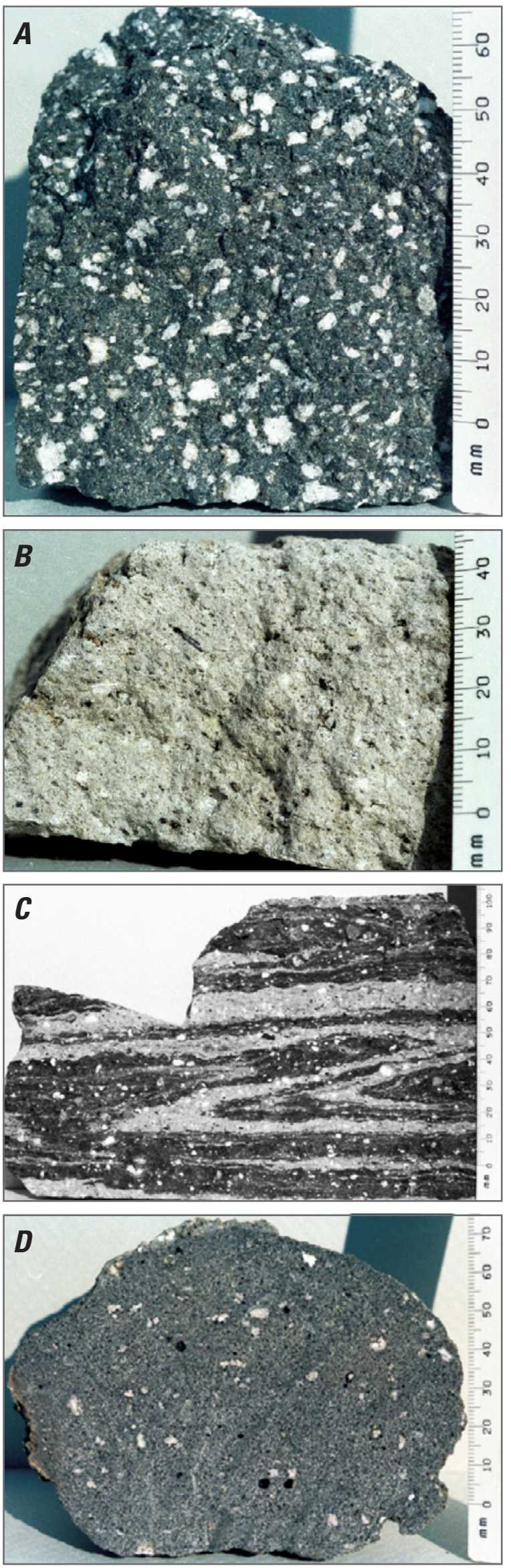

Figure 32. Photographs of hand specimens of four rock types of very different appearance that were produced over a week-long period during the May 1915 eruption from the summit of Lassen Peak. Black dacite $(A)$ erupted as the lava dome during approximately May 14-19 and as the lava flows on the late evening to early morning of May 19-20. Light dacite pumice $(B)$ and banded pumice $(C)$ were erupted during the pyroclastic eruption on May 22. The composition of light dacite pumice is similar to that of the light bands in the banded pumice $(C)$ and to that of the black dacite $(A)$. The composition of the dark bands in the banded pumice $(C)$ is similar to that of blobs of andesite found as quenched inclusions $(D)$ in both the black dacite and the light dacite pumice. All four rock types are the products of incomplete mixing between two magmas with contrasting compositions. The mixing process was interrupted by eruption of the partially mixed magmas (Clynne, 1999).

- Three cold rockfall avalanches from dome $C$ formed Chaos Jumbles. Radiocarbon age is $278 \pm 28$ years B.P. (weighted average of 3 samples)

\section{Hiatus of approximately 800 years}

- Emplacement of dome $\mathrm{F}$

- Hot dome-collapse lithic pyroclastic avalanche from dome $\mathrm{E}$

- Emplacement of dome $\mathrm{E}$

- Hot dome-collapse lithic pyroclastic avalanche from dome D

- Emplacement of dome D

- Emplacement of dome C

\section{Possible short hiatus}

- Emplacement of dome B

- Explosive disruption of dome $A$ by eruption of the upper pyroclastic flow, accompanied by airfall pumice lobe and formation of a tuff cone. Radiocarbon age is $1,103 \pm 13$ years B.P. (weighted average of 16 samples from upper, middle and lower pyroclastic flows)

- Emplacement of dome A

- Eruption of pumiceous lower and middle pyroclastic flows and formation of a tuff cone

- Initial vent opening, air-fall pumice and lithic deposit

Figure 33. Chart giving a summary of events in the formation of Chaos Crags. In stratigraphic order: earliest event at bottom; latest event at top. From Clynne and others (2002). 
of the lower pyroclastic flow, indicating that it flowed through and destroyed mature Jeffrey pine forest. The middle pyroclastic flow apparently followed the same path and rarely contains charcoal. At Lost Creek sand pit, tar from distillation of a tree trunk crosses the contact between the two pyroclastic flows and indicates that the middle pyroclastic flow was erupted and emplaced before the lower pyroclastic flow had completely cooled. Although the best exposure in the sand pit was destroyed by bulldozing in 2008, there are other locations in the pit where these relationships can still be seen.

Shortly after eruption of the lower and middle pyroclastic flows, the vent of the tuff cone was plugged by growth of a small dome, designated dome A. Dome A was mostly destroyed by a large pyroclastic event that emplaced the widespread upper pyroclastic flow. At $3 \mathrm{~km}$ from the vent, the upper pyroclastic flow became confined to the drainages of Lost Creek and Manzanita Creek, where it flowed to distances of $18 \mathrm{~km}$ and $28 \mathrm{~km}$, respectively. The eruption also built a second tuff cone and deposited a lobe of air-fall pumice that can be traced northeast for $25 \mathrm{mi}(40 \mathrm{~km})$. Near the vent, the upper pyroclastic flow contains blocks of dome A up to $1 \mathrm{~m}$ in size. No evidence of erosion has been found between the pyroclastic flows, and all three are closely similar in age. A weighted average of 16 uncalibrated ${ }^{14} \mathrm{C}$ ages from all three pyroclastic flows is $1,103 \pm 13$ B.P. (Clynne and others, 2002).

Subsequent eruption of domes B-F is discussed at Stop D-6. 1.1

27.6 Lost Creek. 1915 debris flows overlie pyroclastic flows from the Chaos Crags eruptions of $1,103 \pm 13$ B.P. ( $\sim 850$ C.E.). For the next 2 miles, the road passes through till of Anklin Meadows (25-17 ka) that is composed primarily of dacite boulders from Lassen Peak. 0.9

28.5 Boundary of West Prospect Peak quadrangle with Manzanita Lake quadrangle to the west. $\mathbf{1 . 2}$

29.7 To the left are the Sunflower Flat domes, a group of eight $41 \pm 1 \mathrm{ka}$, hornblende-biotite rhyodacite domes that were preceded by eruption of air-fall pumice and a pyroclastic flow (the flat over which the road passes). Mature forest obscures the relatively youthful, unglaciated morphology of the domes. $\mathbf{0 . 6}$

30.3 On the right is the bouldery block-lava flow surface of the two-pyroxene andesite of Table Mountain, a shield volcano $(\sim 700 \mathrm{ka})$ related to regional volcanism outside the Lassen Volcanic Center. 1.4

31.7 Talus on left is from the northernmost of the Sunflower Flat rhyodacite domes; the road is once again on pyroclastic flow of Sunflower Flat. 0.8

32.5 Edge of Chaos Jumbles. 0.6

33.1 Stop D-6: Chaos Crags, Chaos Jumbles, and quenched mafic inclusions. The initial events of the Chaos Crags eruptive sequence 1,103 \pm 13 B.P. ( $\sim 850$ C.E.) were discussed at the Lost Creek sand pit (mile 26.5). Subsequent to eruption of the upper pyroclastic flow, a series of domes was emplaced, probably in rapid succession (fig. 34). The domes are designated in chronological order, B through F. Domes D and E had hot collapse events that produced short lithic pyroclastic flows. Approximately 350 years ago (mid 1600s C.E.), the Chaos Jumbles were formed when dome C partially collapsed in three cold rockfall avalanches (see below).

All of the Chaos Crags units are porphyritic hornblende-biotite rhyodacites or dacites containing 67-70 percent $\mathrm{SiO}_{2}$ (fig. 35). Dense rocks contain about 40 percent crystals of plagioclase, biotite, hornblende, quartz, and xenocrystic olivine and augite. Two lithologic groups are recognized: Group 1 comprises the three pyroclastic flows plus domes A and B. This group has a narrow range of composition (69-70 percent $\mathrm{SiO}_{2}$ ), contains sparse quenched inclusions (see below), and displays little evidence of disaggregated inclusions. Group 2 comprises domes $\mathrm{C}-\mathrm{F}$ and contains 67-69 percent $\mathrm{SiO}_{2}$, abundant inclusions (sometimes approaching 20 percent of the rock), and abundant evidence of disaggregated inclusions. The compositional variation in the Chaos Crags is due to disaggregation of inclusions (Tepley and others, 1999).

Quenched inclusions ("blobs") of mafic magma occur in all the Chaos Crags rocks but are especially abundant in the later domes. The inclusions form when blobs of hot mafic magma are injected into cooler silicic magma and are thus chilled (fig. 36). The inclusions display a variety of textures from aphyric (with a relatively coarse-grained groundmass) to porphyritic (with a relatively fine-grained groundmass). The phenocrysts in the porphyritic variety are resorbed felsic crystals derived from mixing with the silicic host magma at the time of inclusion formation. Where both aphyric and porphyritic types occur in the same inclusion, the finer-grained porphyritic material concentrically surrounds the coarsergrained aphyric material. Most quenched inclusions also contain olivine, calcic plagioclase, and augite phenocrysts inherited from their basaltic parent. The magmamixing events associated with the intrusion of basalt and the formation and disaggregation of quenched inclusions play an important role in maintaining the magmatic system at the Lassen Volcanic Center by adding heat and mass to mostly crystalline magma, and in some cases these events provoked eruptions (Guffanti and others, 1996; Clynne, 1999; Klemetti and Clynne, 2014).

The Chaos Jumbles comprise three separate rockfall avalanches covering $2.5 \mathrm{mi}^{2}\left(6.8 \mathrm{~km}^{2}\right)$ that can be distinguished on the basis of flow margins and distribution of block sizes. The deposits consist of a monolithologic breccia of Chaos Crags dacite blocks in a matrix of pulverized dacite. The deposits have steep distal and lateral margins $1-5 \mathrm{~m}$ in height. The first rockfall avalanche was the largest and traveled $\sim 3 \mathrm{mi}(\sim 5 \mathrm{~km})$ with a vertical drop of 2,200 $\mathrm{ft}(670 \mathrm{~m})$ from the breakaway scar on dome $\mathrm{C}$ of Chaos Crags. The other avalanches were successively smaller and shorter, but thicker. The avalanche 


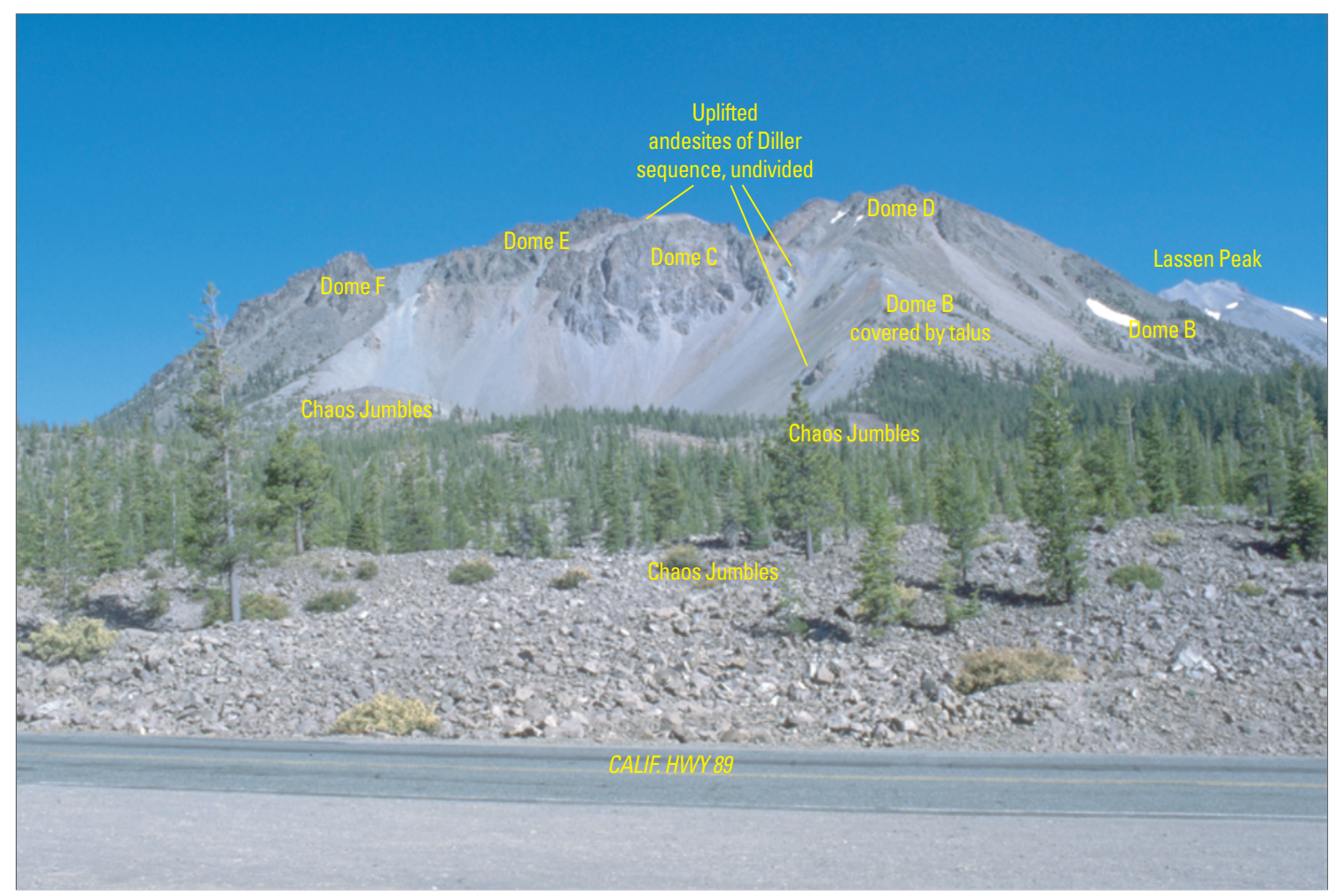

Figure 34. Photograph of Chaos Crags and Chaos Jumbles looking southeast from Calif. Hwy 89. Hummocky surface of the avalanche deposits of Chaos Jumbles (278 28 B.P.; mid 1600 s C.E.) is in the foreground and middle ground. The oval-shaped massive rock cliff (dome $\mathrm{C}$ of Chaos Crags) in the center of the view is the source of the Chaos Jumbles deposits. The highest peak is dome $D$, and the high ground above and to the left of dome $C$ is dome $E$. Small peak on the left is dome $F$. The sparsely tree-covered area (below the large snow bank) on the right flank of dome $D$ is dome $B$, which extends beneath talus from younger domes to the sharp talus-covered ridge beneath dome $\mathrm{D}$. Lassen Peak $(27 \pm 1 \mathrm{ka})$ is on the extreme right at the skyline. Forested area on right below the domes is underlain by young glacial moraines. Light-colored smooth surface above dome $C$ and outcrops to right of dome $C$ are andesite of the Diller Sequence (part of Brokeoff Volcano) uplifted during emplacement of the dome. Photograph 29 of Muffler and others (2010).

Figure 35. Graph of $\mathrm{SiO}_{2}$ content versus $\mathrm{K}_{2} \mathrm{O}$ content for the quenched mafic inclusions and host rocks in Chaos Crags. The composition of the intruded basalt magma was approximately 52 percent $\mathrm{SiO}_{2}$ and 0.7 percent $\mathrm{K}_{2} \mathrm{O}$, and the composition of the resident rhyodacite magma was approximately 70 percent $\mathrm{SiO}_{2}$ and 2.8 percent $\mathrm{K}_{2} \mathrm{O}$. The basalt magma was variably hybridized by mixing with rhyodacite before quenching to form inclusions. Convection of the host rhyodacite magma caused disaggregation of the inclusions (Clynne, 1999; Tepley and others, 1999), thus also hybridizing the rhyodacite.

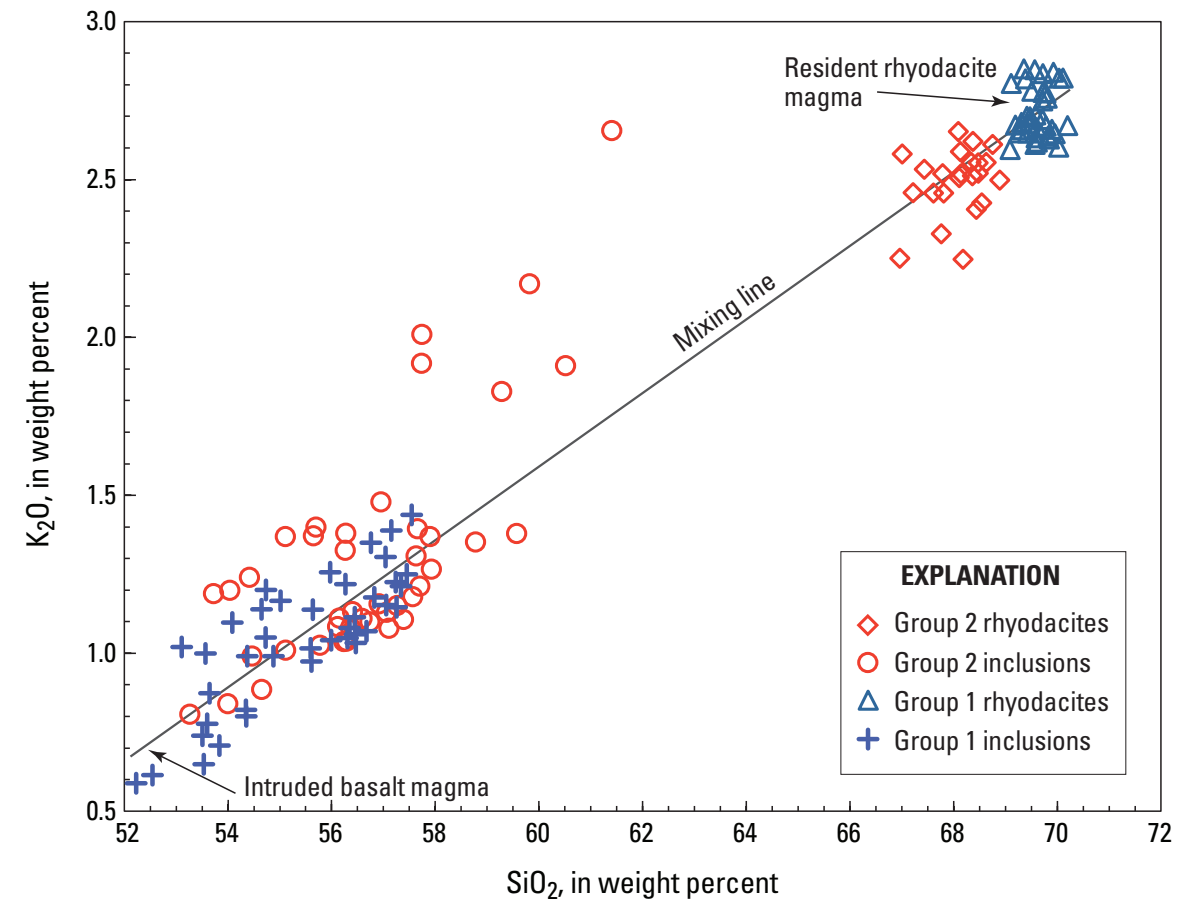


paths were controlled by existing topography. The initial direction of each avalanche was west-northwest towards Table Mountain. The first avalanche deposit rode up nearly $400 \mathrm{ft}(120 \mathrm{~m})$ onto Table Mountain before being deflected to the west. Groovelike linear features on the surface of the deposit were interpreted by Eppler and others (1987) to be strike-slip faults caused by compression during flow as the avalanche was deflected by Table Mountain. Regularly spaced surface ridges are oriented perpendicular (transverse) to the direction of flow. The avalanches apparently were emplaced as material of high yield-strength capable of deforming and shearing rather than as a plug of nondeforming material being carried on a deforming basal layer (Eppler and others, 1987).

Steep-sided volcanic domes are clearly unstable and prone to collapse, but the trigger for the Chaos Jumbles collapse is unknown. A number of mechanisms have been proposed, including an explosion at the base of dome C (Williams, 1932) and renewed volcanic activity on dome $\mathrm{D}$, which was reported by the Whitney Survey to have been steaming in 1857 (Brewer, 1930). However, there is no evidence to support either of these ideas, and the most likely explanation is triggering by a large earthquake, possibly on the Hat Creek Fault $20 \mathrm{mi}$ to the north (see Section I). 1.7

34.8 To the left across Manzanita Lake can be seen Loomis Peak, a rhyodacite lava flow ( $\sim 300 \mathrm{ka})$ of the Bumpass sequence. To the east is the $66 \pm 4$ ka rhyodacite dome of Eagle Peak. To the right, Reflection Lake is a closed depression on the Chaos Jumbles rockfall avalanche. The oldest of the three Chaos Jumbles rockfall avalanches crossed and dammed Manzanita Creek to form Manzanita Lake. Radiocarbon ages of wood samples from trees drowned in the lake that formed behind the dam (Clynne and others, 2002) are consistent with cores taken from trees on the oldest avalanche (Heath, 1959) and confirm the conclusion of Crandell and others (1974) that all three avalanches occurred in quick succession about 350 years ago. $\mathbf{0 . 7}$

35.5 Intersection. To the left, Calif. Hwy 44 leads west to Redding (see Section H). To the right, Calif. Hwy 44 and 89 lead north to Old Station and the Hat Creek Rim. (See Section E).

\section{Section E: Intersection of Calif. Hwys 44 and 89 North to Hat Creek Rim}

0.0 Proceed north on Calif. Hwys 89 and 44. Roadcuts are in rhyodacite pyroclastic-flow deposits from Eagle Peak (66 $\pm 4 \mathrm{ka}$ ). Pass out of the Lassen Volcanic Center and onto rocks related to regional volcanism. $\mathbf{1 . 3}$

1.3 Eskimo Summit is the crest of the Cascade Range in this area. Scoria cones to the left are vents for basaltic andesite and andesite of Red Lake Mountain ( $\sim 75 \mathrm{ka})$. For the next 6 miles, the road lies on slightly older flows from Red Mountain. The northern flank of Table Mountain ( $700 \mathrm{ka})$ is on the right. $\mathbf{4 . 6}$

5.9 Boulders on the flat to the right were deposited by the May 19-20, 1915, debris flow from Lassen Peak. The May 22 debris flow also left a thin deposit in this area, but that debris flow was too fluid to carry large boulders this far. The debris flows lie on the upper pyroclastic flow from Chaos Crags (1,103 \pm 13 B.P.; $~ 850$ C.E.). 1.0

6.9 To left is the block-lava flow front of a 35-ka augiteolivine andesite from Bear Wallow Butte, which is the southernmost of a group of 10 scoria cones and lava flows of the Tumble Buttes chain. The youngest of these, the andesite of Devils Rock Garden, may be Holocene (less than $11.7 \mathrm{ka}$ ), and most of the units are less than $\sim 50 \mathrm{ka}$. This 15 -km-long line of scoria cones and lava flows is oriented at azimuth $345^{\circ}$,

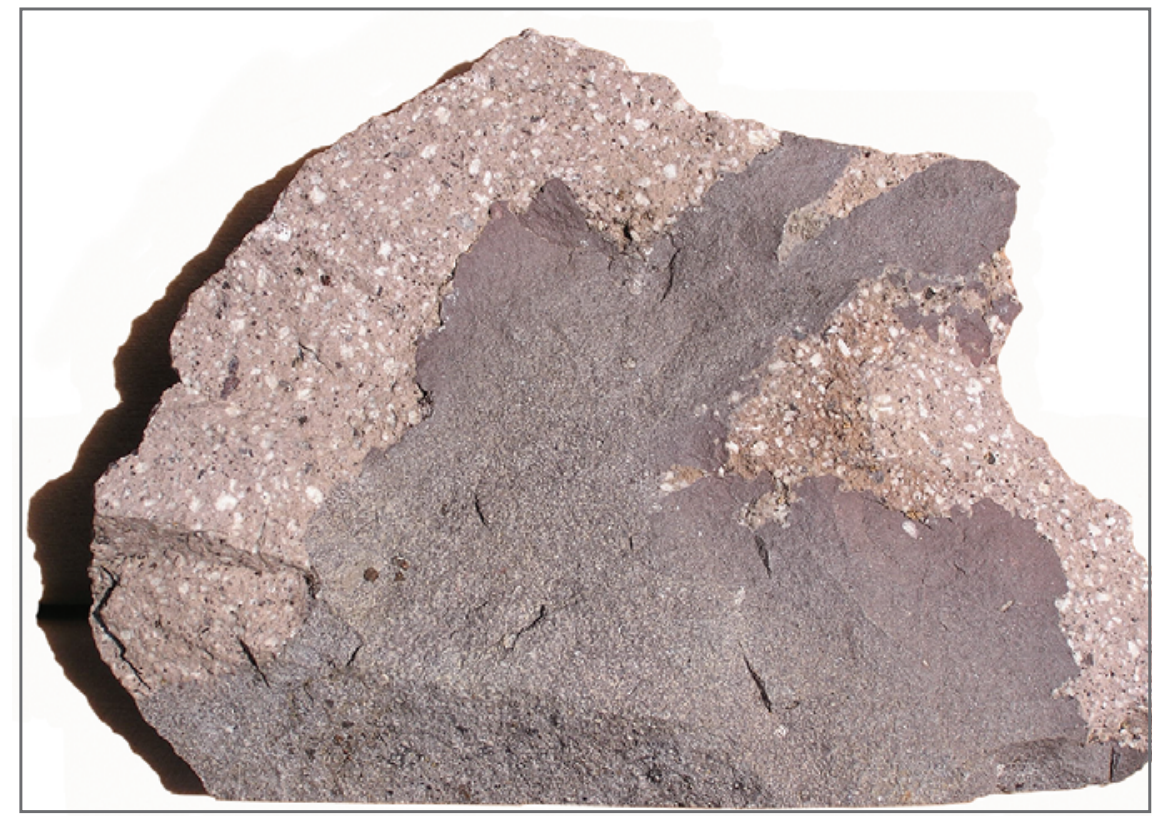

Figure 36. Photograph of quenched mafic inclusion in dacite/rhyodacite of Chaos Crags (width of view $30 \mathrm{~cm}$ ). This inclusion shows some of the features that can be observed in the suite of inclusions from Chaos Crags. The inclusion has a fine-grained quenched rim with a convolute boundary against the host, whereas its core is more coarsely crystalline. Fingers of the inclusion demonstrate how the host silicic magma is pinched off and crystals are "captured" by the mafic inclusion. This inclusion has relatively few host crystals, but a few can be seen even in the core of the inclusion. Brown spots at the lower left are lichen. 
parallel to regional faults, and illustrates fault control of the patterns of vents in the regional volcanism. The most likely future volcanic event in the Lassen area is eruption of mafic magma leading to the formation of a scoria cone and lava flows like those in the Tumble Buttes chain (Clynne and others, 2012). 0.3

7.2 Boundary of Manzanita Peak quadrangle with West Prospect Peak quadrangle to the east. $\mathbf{0 . 6}$

7.8 The flat plateau at 12:00 is the Hat Creek Rim, the upthrown block of a normal fault bounding the Hat Creek Valley on the east (Muffler and others, 1994). Two rocks from the top of the fault scarp gave ages of $1,645 \pm 35 \mathrm{ka}$ and $924 \pm 24 \mathrm{ka}$ (see description at mile 15.1). The rounded shield volcano on the skyline is Blacks Mountain, a nearly aphyric olivine andesite (K-Ar date 2,403 $\pm 19 \mathrm{ka}$; G.B. Dalrymple, written commun., 1991). Good views of Lassen Peak and Chaos Crags to the south. 0.7

8.5 Boundary of West Prospect Peak quadrangle with Old Station quadrangle to the north. On right is a U.S. Forest Service exhibit entitled "Panoramic Point" that once had an excellent view of Lassen Peak to the south. Unfortunately, uncontrolled growth of the forest since it was planted in 1961 has (as of 2015) completely obscured the view. Restrooms and picnic tables are available. $\mathbf{1 . 4}$

9.9 Big Springs, the source of much of the water in Hat Creek, discharge along a prominent fault uplifting the tholeiitic basalt of Twin Bridges (780-730 ka), which is exposed in roadcuts for the next 0.7 mile. $\mathbf{0 . 7}$

10.6 Old Station Post Office is built on glacial outwash of Anklin Meadows ( $17 \mathrm{ka})$, which contains cobbles derived from the dacite of Lassen Peak. 1.5

12.1 Stop E-1: Vents of Hat Creek Basalt. Parking area for the trail to the vent area of the Hat Creek Basalt, a $24 \pm 6 \mathrm{ka}$ (Turrin and others, 2007) low-K olivine tholeiitic (LKOT) basalt lava flow that is characteristic of volcanism in the Basin and Range Province of the western United States. This type of lava erupts from a fissure and builds a low edifice capped by spatter cones. The lava forms an extensive but thin sheet that is distributed by a system of lava tubes. The Hat Creek Basalt flowed for 20 miles to the north in Hat Creek Valley (Anderson, 1940). The rock has sparse olivine phenocrysts in a completely crystalline (holocrystalline) groundmass of small plagioclase, olivine, and augite crystals projecting into abundant tiny vesicles. This texture, termed diktytaxitic, is characteristic of LKOT lava flows. For details of petrology and geochemistry of the Hat Creek Basalt see Anderson (1971), Anderson and others, (1982), and Anderson and Gottfried (1971).

A 1.5-mile hike (round trip) along this trail takes one to the vent area for the Hat Creek Basalt. The trail begins in an old calc-alkaline lava flow and then winds along the margin of the Hat Creek Basalt before ascending onto the flow. The flow locally displays a pāhoehoe surface and is broken by tumuli. White hornblende-biotite pumice lapilli and ash scattered on the ground are from the eruption of Chaos Crags at 1,103 \pm 13 B.P.; $\sim 850$ C.E.) The vent area is a 1.75-mile-long rampart dotted with small spatter cones. Lava was transported away from the vent alignment in tubes. $\mathbf{1 . 6}$

13.7 At the junction of Calif. Hwys 89 and 44, turn right onto Calif. Hwy 44 towards Susanville. Hwy 89 continues north down the Hat Creek Valley towards Burney. 0.3 miles north on Calif. Hwy 89 is the turnoff east to Subway Cave, a U.S. Forest Service exhibit that allows exploration of a part of a lava tube in the Hat Creek Basalt. Note that no services are available on Hwy 44 until the city of Susanville (51 miles). 1.4 15.1 Cross the Hat Creek Fault and climb up the eroded 1,000-foot-high fault scarp of the Hat Creek Rim. The 29-mile-long Hat Creek Fault is contiguous with faults to the south in the eastern part of Lassen Volcanic National Park that also join with faults bounding the Lake Almanor graben, a total distance of more than 50 miles. Together these structures define the westernmost major graben of the Basin and Range Province. The Basin and Range structural regime is expanding to the west and impinging upon the Cascade volcanic arc in the Lassen area. Older faults (for example, the Butte Creek Rim) occur farther to the east.

Rocks exposed on the eroded fault scarp of the Hat Creek Rim are regional basalts and andesites similar to the volcanic rocks on the west side of Hat Creek Valley. Two rocks from the top of the fault scarp gave ages of 1,645 $\pm 35 \mathrm{ka}$ and $924 \pm 24 \mathrm{ka}$ (Clynne and Muffler, 2010). Total vertical offset has been at least 1,000 feet in the past million years. The valley bottom has been filled with younger basalt flows, so the observed offset is a minimum amount.

Recent movement on the Hat Creek Fault is demonstrated by offset of lava ponded against the fault scarp. The most recent movement occurred since $\sim 15 \mathrm{ka}$ and offsets the Hat Creek Basalt by as much as 30 meters (Muffler and others, 1994; Walker, 2008; Walker and Kattenhorn, 2008; Blakeslee and Kattenhorn, 2013). A single event that large would have an earthquake magnitude of at least 8 ; thus it is likely that the movement occurred in more than one event. The existence of such a prominent, young fault with no associated modern seismicity suggests that movement on the Hat Creek Fault is episodic over periods of perhaps hundreds or thousands of years. Despite the lack of historical activity, the Hat Creek Fault is clearly an active structure capable of large earthquakes (Wills, 1991). Walker and Kattenhorn (2008) and Blakeslee and Kattenhorn (2013) estimate that the fault has the potential to produce an earthquake of moment magnitude of 6.7 with a recurrence interval of $667 \pm 167 \mathrm{yr} . \mathbf{1 . 4}$

16.5 Turn left onto side road to Hat Creek Rim Overlook. $\mathbf{0 . 4}$ 
16.9 Stop E-2: Hat Creek Rim Overlook

From this vantage point at the top of the Hat Creek Fault scarp, the crest of the Cascade Range from the Lassen Volcanic Center to Mount Shasta is visible. To the south, in the Lassen Volcanic Center, prominent visible features include Lassen Peak, Chaos Crags, and Raker Peak, which is a $270 \pm 18$ ka hybrid andesite of the Twin Lakes sequence. Regional volcanoes include Table Mountain ( $700 \mathrm{ka}$ ) and Badger Mountain, a faulted $708 \pm 21 \mathrm{ka}$ andesite shield.

Volcanoes of the Cascade Range north of Lassen Peak are identified in an annotated panorama of the Cascade Range (fig. 37) taken from Parhams Point, 1.85 miles south-southeast (see Stop G-1 of Section G). These volcanoes are typical of Cascade Range volcanoes outside volcanic centers or away from large volcanoes. The flat, brush-covered area in the foreground and valley floor is the $24 \pm 6$ ka tholeiitic Hat Creek Basalt (Turrin and others, 2007), and the low mound just to the south of Old Station is its vent area. West of the vent area of the Hat Creek Basalt is the north-south-trending Sugarloaf chain of sparsely porphyritic olivine and pyroxene basaltic andesite and andesite volcanoes (all calc-alkaline), consisting of

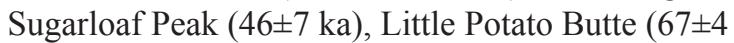
$\mathrm{ka})$, Potato Butte $(77 \pm 11 \mathrm{ka})$, and several smaller vents (Turrin and others, 2007). Together the Potato Buttes, the Hat Creek Basalt, and Sugarloaf Peak obscure the western boundary fault of the Hat Creek Valley that can be seen as a scarp farther north.

In the distance, to the left of Sugarloaf Peak, the cones in the Red Lake Mountain group and the southern end of the Tumble Buttes chain (Bear Wallow Butte) can be discerned. Hidden behind Sugarloaf Peak is deeply glaciated Magee Volcano (Borg, 1989), the upper part of which has a K-Ar date of $210 \pm 120 \mathrm{ka}$. Older volcanoes and flows in this area are cut by many small faults. The prominent cone-shaped mountain to the north is Burney Mountain. This volcano comprises six pyroxene dacite lava domes emplaced on top of each other; the oldest dome has a ${ }^{40} \mathrm{Ar} /{ }^{39} \mathrm{Ar}$ age of $280 \pm 6$ ka (M.A. Lanphere, written commun., 1998).
The area east of Burney Mountain contains a number of young scoria cones and lava flows, some of which may be postglacial.

Mount Shasta can be seen in the distance. With a volume of $>350 \mathrm{~km}^{3}$, it is the largest composite volcano in the High Cascade Range (Calvert and Christiansen, 2011). Its elevation is 14,162 feet $(4,318 \mathrm{~m})$, nearly 4,000 feet $(1,130 \mathrm{~m})$ higher than Lassen Peak. At $>300$ ka, Mount Shasta experienced an enormous debris avalanche that nearly destroyed the ancestral Sand Flat volcano (Crandell and others, 1984; Crandell, 1989), dated at 700-600 ka (Calvert and Christiansen, 2011). The present edifice comprises four overlapping cones (Christiansen and Miller, 1989; Calvert and Christiansen, 2011): Sargents Ridge ( 300-100 ka), Misery Hill (50-35 ka), Shastina ( 11 $\mathrm{ka})$, and Hotlum (8.8-3.1 ka). The last activity of Mount Shasta may have been a very small eruption in 1786 C.E. (Finch, 1930). Although this specific eruption is questionable, there is evidence of mildly explosive activity at Mount Shasta during the last few millennia, but probably no magmatic eruptions since $3.1 \mathrm{ka}$ (R.L. Christiansen and A.T. Calvert, oral commun., 2015).

\section{Section F: Hat Creek Rim Overlook to Westwood and Chester}
0.0
Return to Calif. Hwy 44. 0.4
0.4 Turn left onto Calif. Hwy 44 and proceed north and then east towards Susanville. 1.6
2.0 On right is U.S. Forest Service Road 33N56. An excellent view of the Cascade Range (fig. 37) can be obtained by detouring $1.3 \mathrm{mi}$ south on this unpaved road (see Stop G-1). 0.4
2.4 U.S. Forest Service Road 33N20 to right. $\mathbf{0 . 1}$
2.5 Boundary of Old Station quadrangle with Swains Hole quadrangle to the east. $\mathbf{0 . 5}$
3.0 U.S. Forest Service Road 33N54 to left. $\mathbf{0 . 5}$
3.5 Summit Lake on the left is in a small fault-bounded depression. $\mathbf{0 . 7}$

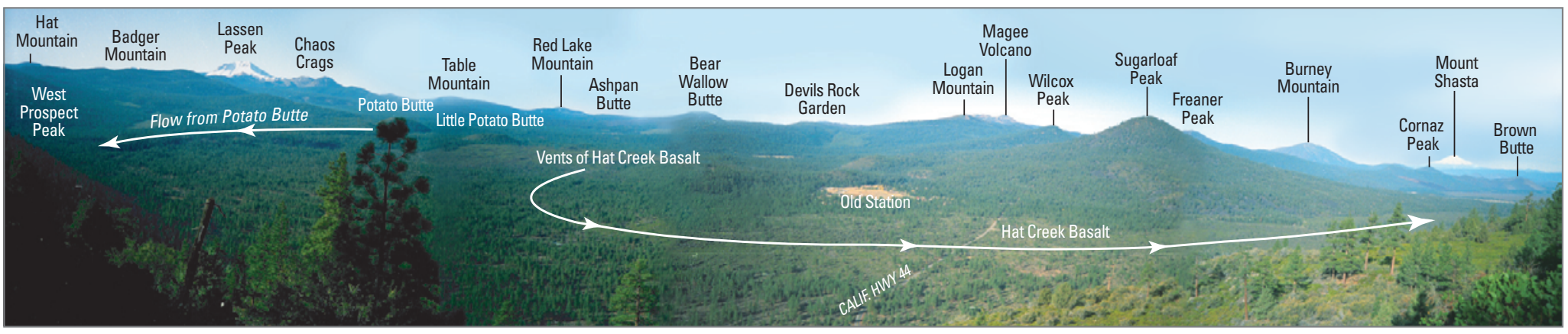

Figure 37. Panoramic photograph looking southwest (left) to northwest (right) from Parhams Point across the Hat Creek Graben and the Hat Creek Basalt $(24 \pm 6$ ka) towards the crest of the Cascade Range north of Lassen Volcanic National Park. 
4.2 U.S. Forest Service Road 33N56 to right. $\mathbf{0 . 3}$

4.5 Roadcut in basaltic andesite of Signal Butte $(\sim 1,000$ $900 \mathrm{ka}$ ), which erupted from the large scoria cone $0.7 \mathrm{mi}$ at $1: 30$. This lava flow is cut by small faults oriented parallel to the Hat Creek Fault and can be considered as the youngest unit of the Hat Creek Rim. 0.7

5.2 Contact with the tholeiitic basalt of Calif. Hwy 44 (190 \pm 18 ka). 0.1

5.3 Roadcuts in the tholeiitic basalt of Calif. Hwy 44. This thin lava flow of sparsely porphyritic olivine basalt (49.6 percent $\mathrm{SiO}_{2}$ ) erupted from a fissure at hill 5855 , $1.75 \mathrm{mi}$ to the south-southwest. This extensive lava flow was fed by lava tubes and flowed north along the base of Butte Creek Rim for $>9 \mathrm{mi}(15 \mathrm{~km})$. It also flowed to the west and barely spilled over the Hat Creek Rim. The surface of the flow is relatively flat and has low relief, although punctuated by widely spaced tumuli. $\mathrm{A}^{40} \mathrm{Ar} /{ }^{\beta 9} \mathrm{Ar}$ age of $190 \pm 18 \mathrm{ka}$ is consistent with the flow's excursional magnetic direction (D.E. Champion, written commun., 2006). 0.9

6.2 Lassen County line. $\mathbf{1 . 6}$

7.8 View back to the right at 3:00 to 4:30 of West Prospect

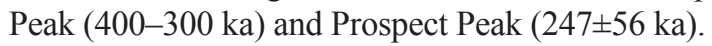
These andesite and basaltic andesite shield volcanoes are typical of regional calc-alkaline edifices.

At 2:00 is Sunrise Peak, the highly glaciated vent for the basalts of Sunrise Peak ( $393 \pm 4 \mathrm{ka}$ ), at the western edge of the Caribou Volcanic Field just east of Butte Lake.

In the distance at 9:30 is the shield volcano of Blacks Mountain, a nearly aphyric olivine andesite (K-Ar date 2,403 \pm 19 ka; G.B. Dalrymple, written commun., 1991). This unusual regional calc-alkaline rock has a silica content of 59 percent $\mathrm{SiO}_{2}$ but contains only a few, tiny olivine phenocrysts.

Highway in this area passes over glacial outwash brought from the volcanic highlands to the south along Butte Creek. 0.8

8.6 At right is U.S. Forest Service Road 32N21, a washboard unpaved road that goes $\sim 6$ miles south into LVNP. From the end of the road at Butte Lake (Section G, Stop G-3) is a 1.8-mile trail that goes to the top of Cinder Cone, which, at 1666 C.E., is the youngest mafic volcano in the Lassen region (Sheppard and others, 2009). The products of the Cinder Cone eruption consist of five lava flows, two nested scoria cones and a widespread mafic ash-fall deposit (Clynne and others, 2000a; Clynne and others, 2002). Cinder Cone is part of the younger Twin Lakes sequence of the Lassen domefield. A scramble from Butte Lake up the west flank of Sunrise Peak east of Butte Lake to a bluff at approximately UTM 10T E0645650 N4490680 (NAD27) is rewarded by a spectacular view of Cinder Cone, Lassen Peak, and Chaos Crags (cover; photograph 31 of Muffler and others, 2010). 1.6
10.2 Boundary of Swains Hole quadrangle with Poison Lake quadrangle to the east. $\mathbf{0 . 1}$

10.3 U.S. Forest Service Road 32N26 goes south towards the young Bidwell Spring chain of the Caribou Volcanic Field. 0.5

10.8 View at 12:00 of scoria cones of the Poison Lake chain, a line of 39 small, monogenetic calc-alkaline basaltic volcanoes in a zone $14 \mathrm{~km}$ long and $2 \mathrm{~km}$ wide trending north-northwest parallel to and partially burying nearby Quaternary normal faults. 1.9

12.7 Stop F-1: Poison Lake chain. On the left is Poison Lake. Visible from this point are several prominent scoria and agglutinate cones that mark vents for volcanoes of the Poison Lake chain, part of the Caribou Volcanic Field. The northern half of the Caribou Volcanic Field, including the Poison Lake chain, has not been glaciated, and constructional forms are well preserved. The 39 units of the Poison Lake chain fall into 9 distinct groups based on stratigraphy, petrography, and major-element geochemistry (Muffler and others, 2011). Many units contain only sparse olivine; a few units are distinctly porphyritic with olivine, clinopyroxene, and plagioclase. $\mathrm{MgO}-\mathrm{SiO}_{2}$, $\mathrm{K}_{2} \mathrm{O}-\mathrm{SiO}_{2}$, and $\mathrm{TiO}_{2}-\mathrm{SiO}_{2}$ variation diagrams illustrate clear differences in compatible and incompatible elements among the groups. Limited trace-element and ${ }^{87} \mathrm{Sr} /{ }^{86} \mathrm{Sr}$ data suggest little if any interaction with the upper crust. Precise ${ }^{40} \mathrm{Ar} /{ }^{39} \mathrm{Ar}$ determinations show that the lavas erupted at 110-100 ka. Paleomagnetic remanent directions suggest that the entire Poison Lake chain could represent three short-lived episodes of volcanism within a period as brief as 500 years. Collectively, the data indicate that each of the 9 groups represents a small, discrete magma batch generated in the mantle and stored briefly in the lower crust. Episodic movement along a north-northwest normal fault zone provided transitory conduits for these batches of magma to ascend to the surface and erupt as distinct volcanic groups, each aligned along a segment of the Poison Lake chain.

At 10:00 is Cal Mountain, a regional calc-alkaline shield volcano of olivine andesite $(2,345 \pm 49 \mathrm{ka})$. In the distance at 9:00 is Blacks Mountain (2,403 $\pm 19 \mathrm{ka}) \mathbf{2 . 3}$

15.0 Road to Pittville on left. For the next 8 miles, Calif. Hwy 44 traverses a flat valley underlain by the tholeiitic basalt of Grays Valley, a thin, extensive sheet of nearly aphyric, tholeiitic, olivine basalt (48.5 percent $\mathrm{SiO}_{2}$ ) erupted at $\sim 600$ ka from a spatter rampart east of Bogard Buttes (at 1:00). Multiple flow units of tube-fed pāhoehoe flowed north and filled the valley between Bogard Buttes, Cal Mountain, Cone Mountain (at 9:00), and Crater Mountain (at 11:00), all members of the regional calc-alkaline suite. See Stop F-2 for further discussion of Bogard Buttes and Crater Mountain.

To the left (north of the highway) are the tracks of the Burlington Northern Santa Fe (BNSF) Railroad, 
originally the Western Pacific Railroad. From here to mile 44 just north of Westwood, this railroad parallels the field-trip route to the east. 1.4

16.4 To the right of Calif. Hwy 44, a grove of aspen marks Robbers Spring, at the toe of a flow of the basalts of Robbers Spring (101.5 $\pm 8.7 \mathrm{ka}$ ), part of the Poison Lake chain (Muffler and others, 2011). 0.9

17.3 Boundary of Poison Lake quadrangle with Bogard Buttes quadrangle to the south. $\mathbf{0 . 5}$

17.8 Boundary of Bogard Buttes quadrangle with Pine Creek Valley quadrangle to the east. $\mathbf{0 . 7}$

18.5 Mountains to the right of Calif. Hwy 44 are underlain

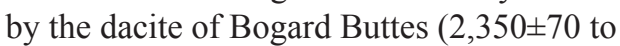
2,225 $\pm 49 \mathrm{ka}) . \mathbf{1 . 7}$

20.2 Inconspicuous vents for the tholeiitic basalt of Grays Valley are in the woods to the right. $\mathbf{0 . 7}$

20.9 Turn right on U.S. Forest Service Road 32N09 to southwest (right). 0.1

21.0 Turn right at entrance to Bogard Buttes Rest Area. 0.2

21.2 Bogard Buttes Rest Area. Views from the rest area itself are obscured by trees.

Return to the intersection of U.S. Forest Service Road 32N09 and Calif. Hwy 44 for a good view to the northeast. 0.3

21.5 Stop F-2: Calc-alkaline volcanoes and intervening LKOT basalts. The topography of the Bogard Buttes area is typical of that located behind the active Cascade Arc (see Borg, 1995). East of the Poison Lake chain, most of the volcanoes are 2-3 million years old, although a few are younger. The landscape is dotted with shield volcanoes, and the intervening valleys are flooded with widespread sheets of LKOT basalt lava. From this vantage point a number of shield volcanoes can be seen, including Crater Mountain, Bogard Buttes, Campbell Mountain, Logan Mountain, and Antelope Mountain. The shield volcanoes are composed of basaltic andesite to andesite lavas that are generally porphyritic, but without large or complexly zoned crystals. Each edifice is different; most are composed of a single rock type, but some have a narrow range of compositions. The density of faults on each volcano gives a relative indication of its age.

The large shield volcano to the northeast is Crater Mountain. Its surface is covered by forested block lava flows of augite-hypersthene andesite, with abundant small phenocrysts. A second, slightly more mafic olivine andesite lies mostly buried by the main edifice. The volcano is relatively large, with a nearly 5 -mile diameter, rises about $1,750 \mathrm{ft}(530 \mathrm{~m})$ above the valley and has a volume of about $10 \mathrm{~km}^{3}$. Crater Mountain is undated, but it is little eroded, has a thin soil, and is unfaulted. Its summit is weakly glaciated but still has a partially preserved scoria cone. It has a normal paleomagnetic direction and an age of $\sim 500 \mathrm{ka}$. The lake at the summit is probably a cirque dammed by glacial deposits. U.S. Forest Service Road 32N08 is a well-maintained gravel road and makes a nice side trip to the summit of Crater Mountain. The road leaves the highway just northwest of the entrance to the rest area.

Bogard Buttes, the forested shield volcano to the northwest of the rest area, is composed of a single type of porphyritic augite-hypersthene dacite. It has a basal diameter of about 3 miles, rises 1,900 feet $(580 \mathrm{~m})$ above the valley floor, and has a volume of about 4 $\mathrm{km}^{3}$. The edifice has a thick soil, is cut by several conspicuous faults (not visible from this vantage point) and has no preserved vent area or scoria. Two K-Ar

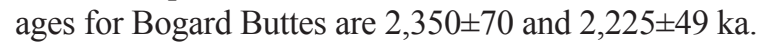

The rest area is constructed on the proximal high ground of the tholeiitic basalt of Grays Valley. This flow vented from the area of the inconspicuous low hills $0.25-0.5$ mile west of the rest area and flowed northward between Crater Mountain and Bogard Buttes into Grays Valley. The tholeiitic basalt of Grays Valley is a nearly aphyric, diktytaxitic, olivine basalt. The valley floor to the east of the rest area is flooded with another tholeiitic basalt lava flow, the basalt of Pine Creek Valley, which vented from an inconspicuous hill just above the fault scarp about 2 miles south-southeast of the rest area. The tholeiitic basalt of Pine Creek Valley is also a nearly aphyric, diktytaxitic, olivine basalt, but the two flows have subtle chemical differences. Neither of these basalt flows is dated, but both have normal polarity, thin soils, are relatively uneroded, and probably about $600 \mathrm{ka}$ in age.

This part of Calif. Hwy 44 marks the route of both the Lassen Trail and the Nobles Trail to California from Missouri (Strong, 1989). The Lassen Trail was first traversed in 1847 by a party led by Peter Lassen. Coming from Goose Lake north of Alturas, the trail led down the Pit River and then south to what is now Calif. Hwy 44. The trail then went southeast and south, roughly paralleling the field-trip route, to Westwood and Big Meadows (now Lake Almanor) and thence down the ridge between Mill Creek and Deer Creek to the Sacramento Valley. The Nobles Trail, charted in 1851 by William Nobles, came west from Susanville along this section of Calif. Hwy 44, went south between Cinder Cone and Prospect Peak, crossed into the Hat Creek drainage, and then went down Shingletown Ridge to the Sacramento Valley. Along the parts of these trails near Calif. Hwy 44, emigrants to California in the early 1850 s going southeast on the Lassen trail were passing emigrants on the Nobles Trail travelling in the opposite, northwest direction! $\mathbf{1 . 0}$

22.5 Calif. Hwy 44 crosses over a nearly imperceptible contact between the tholeiitic basalt of Grays Valley and the tholeiitic basalt of Pine Creek Valley (also $\sim 600 \mathrm{ka}$ ). Vents for this LKOT are in the hills to the south at 1:30. 0.7

23.2 To the right is U.S. Forest Service Road 31N26 leading west to Bogard Campground. The prominent scoria cone 2 miles away at 1:30 is the vent for the calc-alkaline 
basalt of Round Valley Butte (K-Ar date $477 \pm 25 \mathrm{ka}$; G.B. Dalrymple, written commun., 1994). This basalt is separated from the tholeiitic basalt of Grays Valley by a series of discontinuous, en echelon normal faults (up to the southwest) that cut both units. $\mathbf{2 . 1}$

25.3 Roadcuts in the tholeiitic basalt of Pine Creek Valley. $\mathbf{0 . 7}$

26.0 Turn right on Lassen County Road A21 south towards Westwood. [If one is not following the field trip guide to Westwood, he or she can continue east on Calif. Hwy 44 another 17.5 miles to a junction with Calif. Hwy 36. From there, Calif. Hwy 36 continues another 6 miles to the town of Susanville, where food, lodging, and gas services are available. A 1:100,000-scale geologic map of the Susanville Quadrangle (Grose and others, 2013) shows the geology along the route.] $\mathbf{0 . 2}$

26.2 Road curves right up the fault scarp onto the basalt of Round Valley Butte. 2.6

28.8 Road curves sharply left as it passes off the basalt of Round Valley Butte. 0.7

29.5 Boundary of Pine Creek Valley quadrangle with Swain Mountain quadrangle to the south. $\mathbf{0 . 1}$

29.6 Road passes from the basalt of Round Valley Butte onto the basaltic andesites of Susan River. These old calcalkaline rocks $(>2,580 \mathrm{ka})$ show little constructional morphology and are thickly mantled by soil and by till of older glaciations (70-60 ka or older; see fig. 11). 0.7

30.3 To the right, Lassen County Road 110 on the north side of the Susan River leads to Silver Lake on the east boundary of the Caribou Wilderness. The Caribou Wilderness comprises the highly glaciated, southern part of the Caribou Volcanic Field (fig. 38; see also fig. 10). 0.2

30.5 To the right, U.S. Forest Service Road 30N21 on the south side of the Susan River also leads to the Caribou Wilderness. 0.3
30.8 Through the trees to the left, one can catch a quick glimpse of the scoria cone of Bennett Knoll, a calcalkaline basalt. Hidden in the trees south of Bennett Knoll is Clover Butte, also a calc-alkaline scoria cone (K-Ar date $688 \pm 31$ ka; G.B. Dalrymple, written commun., 1994). 0.2

31.0 Road passes from the andesites of Susan River onto till of older glaciations ( 60 to $>130 \mathrm{ka} . \mathbf{0 . 6}$

31.6 To the right, U.S. Forest Service Road 30N81 goes to the west along the northern flank of Swain Mountain, a large shield volcano composed of porphyritic olivine basaltic andesite with a K-Ar age of 1,570 $\pm 35 \mathrm{ka}$ (G.B. Dalrymple, written commun., 1994). 0.1

31.7 Lassen County Road A21 passes onto the tholeiitic basalt of Westwood (401 $\pm 7 \mathrm{ka}$; weighted average of five ${ }^{40} \mathrm{Ar}{ }^{\beta 9} \mathrm{Ar}$ determinations by P.R. Renne and one by B.D. Turrin, written commun.). The inconspicuous vent for this very extensive basalt flow is hidden in the trees at 9:00, just south of Clover Butte. The tholeiitic basalt of Westwood flows at least 23 miles to the south and southwest into the canyon of the North Fork Feather River, 2.5 miles south of Lake Almanor. 1.0

32.7 View at 12:00 of the andesite of Brush Hill, a calcalkaline edifice probably of late Pliocene age. $\mathbf{0 . 7}$

33.4 To right is the road to a snowmobile park. $\mathbf{1 . 0}$

34.4 Flow surface of the tholeiitic basalt of Westwood. Note the intermittently preserved surface morphology of this LKOT lava flow. $\mathbf{0 . 9}$

35.3 View at 12:00 of the andesite of Brush Hill. 2.6

37.9 Tumuli on surface of tholeiitic basalt of Westwood. $\mathbf{1 . 8}$

39.7 Boundary of Swain Mountain quadrangle with Westwood West quadrangle to the south. $\mathbf{1 . 3}$

41.0 Boundary of Westwood West quadrangle with Westwood East quadrangle to the east. $\mathbf{0 . 1}$

Figure 38. Photograph looking southwest across Silver Lake, illustrating the glaciated physiography of the southern part of the Caribou Volcanic Field. The cliffs on the far side of Silver Lake represent the glaciated flow margin of the basaltic andesites of Silver Lake $(400 \pm 14 \mathrm{ka})$, stripped of surficial vesicular blocks to expose the dense core of the lava flow. The summit of North Caribou is the glaciated agglutinate vent of the basaltic andesites of North Caribou ( $350 \mathrm{ka}$ ). Photograph by Carl E. Mortensen. Units generalized from photograph 36 of Muffler and others (2010).

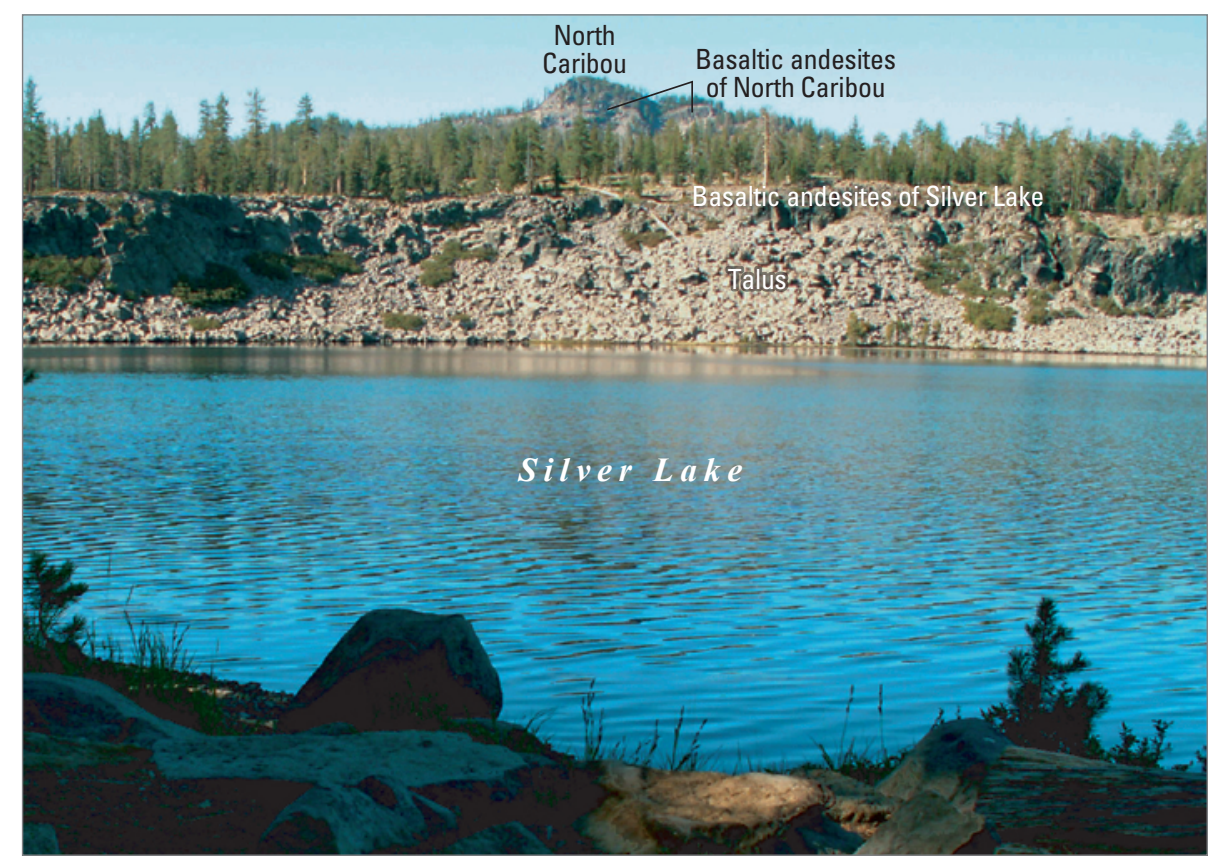


41.1 Lassen County Road A21 crosses Burlington Northern Santa Fe (originally Western Pacific) Railroad and Bizz Johnson National Recreation Trail (to east towards Susanville; see http://www.traillink.com/trail/ bizz-johnson-national-recreation-trail.aspx). 0.2

41.3 Mountains in distance at 12:00 are composed of Paleozoic metamorphic rocks in the northernmost Sierra Nevada. 2.8

44.1 Junction with Calif. Hwy 36 at Westwood. Turn right towards Chester and Red Bluff. 0.3

44.4 Calif. Hwy 36 crosses Burlington Northern Santa Fe Railroad. 0.1

44.5 Boundary of Westwood East quadrangle with Westwood West quadrangle to the west. $\mathbf{2 . 5}$

47.0 On left, Calif. Hwy 147 to Clear Creek. 0.5

47.5 Young normal fault (down to west) cutting tholeiitic basalt of Westwood. Lassen Trail crosses the highway at the historical marker just west of the fault. $\mathbf{0 . 2}$

47.7 Plumas County Line. $\mathbf{1 . 4}$

49.1 Pass from tholeiitic basalt of Westwood onto tholeiitic basalt of Rock Creek ( $989 \pm 49 \mathrm{ka})$. This older basalt has more subdued flow topography and reversed magnetic polarity. $\mathbf{2 . 1}$

51.2 Roadcut in tholeiitic basalt of Rock Creek. Boundary of Westwood West quadrangle with Chester quadrangle to the west. $\mathbf{0 . 2}$

51.4 View at 12:00 of Butt Mountain, to the west of Lake Almanor. Butt Mountain is composed of andesitic rocks related to the Yana Volcanic Center and has a ${ }^{40} \mathrm{Ar} /{ }^{39} \mathrm{Ar}$ age of 3,320 $\pm 80 \mathrm{ka}$ (M.A. Lanphere, written commun., 1996). 0.8

52.2 At left is Plumas County Road A13 leading southeast to Hamilton Branch and the Almanor Peninsula. Continue west on Calif. Hwy 36. 0.1

52.3 Contact with the basalts and basaltic andesites of Mud Creek Rim. This thick ( $>400 \mathrm{~m}$ ) section of calc-alkaline lava flows is exposed primarily in fault scarps that form the east boundary of the north part of the Lake Almanor graben. Four K-Ar ages range from $2,785 \pm 16$ ka to $2,200 \pm 49 \mathrm{ka} . \mathbf{0 . 7}$

53.0 Roadcut in basalts and basaltic andesites of Mud Creek Rim. $\mathbf{0 . 2}$

53.2 Rest area on left side of highway. Views across Lake Almanor to the Lassen and Maidu Volcanic Centers can be obtained by scrambling through the trees below the rest area. Beyond the rest area, Calif. Hwy 36 angles down a major fault scarp that forms the east boundary of the Lake Almanor Graben. $\mathbf{0 . 2}$

53.4 Large roadcut exposes a lava flow with a baked zone at the base and a silicic ash flow. $\mathbf{1 . 3}$

54.7 Large roadcut exposes basalts and basaltic andesites of Mud Creek Rim. 0.4

55.1 Turnoffs to North Shore and Last Chance campgrounds. 0.4

55.5 East shore of Lake Almanor. Across the northern arm of Lake Almanor is a beautiful view of Brokeoff
Volcano and the Bumpass and Eagle Peak sequences of the Lassen domefield. A few cars can pull off onto the right shoulder of the highway, but be very aware of the fast-moving traffic coming down the fault scarp from the east. Much better parking is on the left (south) side of the highway. Safest access to this parking is to drive west across the causeway into Chester, make a $\mathrm{U}$ turn, and drive back to the safe parking on the south side of Calif. Hwy 36. 1.6

57.1 Intersection to right at Fire Station with Plumas County Roads 318 (to Juniper Lake) and 312 (to Warner Valley and Drakesbad, in the southeast corner of LVNP). A trail leads from the warm springs at Drakesbad through beautiful meadows and virgin forest to Devils Kitchen, a high-temperature fumarolic area (Muffler and others, 1982, 1983).

\section{Section G: Alternate Route from Hat Creek Rim Overlook to Cinder Cone and Poison Lake Chain}

If one walks into Cinder Cone from Butte Lake, section $\mathrm{G}$ could take a full day; if one just drives it, a few hours will suffice. From mile 2.0 on, the road log follows graded gravel and dirt roads, sometimes washboard and rough. Not recommended for buses or cars with low clearance.

0.0 Return to Calif. Hwy 44. 0.4

0.4 Turn left onto Calif. Hwy 44 and proceed north and east towards Susanville. 1.6

2.0 Turn right onto U.S. Forest Service Road 33N56. 1.4

3.4 Stop G-1: Parhams Point. This informally named overlook on the Hat Creek Rim presents an excellent view of the Cascade Range (fig. 37). Scramble 30 feet down the scarp to several rocky outcrops below the Pacific Crest trail. Watch out for poison oak and rattlesnakes. View is best in the morning. The rock here (best seen on the east side of the road) is a very porphyritic olivine-augite basalt, not the tholeiitic "Burney Basalt" shown on Macdonald (1964). Continue southeast on U.S. Forest Service Road 33N56 away from the Hat Creek Rim. 0.6

4.0 Turn right (south) on U.S. Forest Service Road 33N20. 0.2

4.2 Junction with U.S. Forest Service Road 33N20A leading right to Baker Lake. Continue south on U.S. Forest Service Road 33N20 passing onto the basaltic andesite of Signal Butte (1,000 to $900 \mathrm{ka}) .0 .8$ Contact with the tholeiitic basalt of Calif. Hwy 44. This thin lava flow of sparsely porphyritic olivine basalt (49.6 percent $\mathrm{SiO}_{2}$ ) erupted from a fissure at hill $5855,2.6 \mathrm{mi}$ to the southeast. This extensive lava flow was fed by lava tubes and flowed north along the base of Butte Creek Rim for $>9 \mathrm{mi}(15 \mathrm{~km})$. It also flowed to the west and barely spilled over the Hat Creek Rim. The surface of the flow is relatively flat and has low 
relief, although punctuated by widely spaced tumuli. $\mathrm{A}^{40} \mathrm{Ar} /{ }^{39} \mathrm{Ar}$ age of $190 \pm 18 \mathrm{ka}$ is consistent with the flow's excursional magnetic direction (D.E. Champion, written commun., 2006). $\mathbf{0 . 2}$

5.2 Boundary of Old Station quadrangle with Swains Hole quadrangle to the east. $\mathbf{0 . 8}$

6.0 Complex road junction. Bear $30^{\circ}$ to right on U.S. Forest Service Road 32N56. 2.3

8.3 On left is a dirt road leading north 0.3 mile to a small "cinder pit" in the tholeiitic basalt of Calif. Hwy 44. The low hills north of the cinder pit comprise the partially eroded spatter rampart that is the vent for this basalt. 0.2

8.5 Stop G-2: Andesite of hill 7416. Pull off on right at spur Road 32N56C. Walk back $100 \mathrm{~m}$ to the west along Road 32N56 to inspect flow front of the andesite of hill 7416, part of the younger Twin Lakes sequence of the Lassen domefield. This thick (as much as $50 \mathrm{~m}$ ) block-lava flow of porphyritic olivine-augite andesite (57.5 percent $\mathrm{SiO}_{2}$ ) erupted from a vent marked by a scoria cone on the upper east flank of West Prospect Peak. Lava flowed northward down the crease between

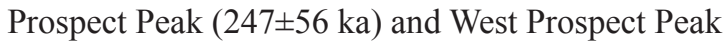
(400-300 ka) and partially buried the trace of the Hat Creek Fault on the north flank of Prospect Peak. The flow has not been glaciated, is unforested, and is completely lacking in soil; its original block surface is well preserved. Climb to the top of the flow front for a view of the top surface of the flow and a distant view of the vent. The lava contains a disequilibrium phenocryst assemblage consisting of strongly reacted sodic plagioclase, quartz, hornblende, and biotite(?) and unreacted olivine, augite, and calcic plagioclase. The unit is not dated, but its age is well constrained by stratigraphy. The flow is older than the pumice of Chaos Crags (1,103 \pm 13 B.P.) but is not offset by the Hat Creek Fault, which offsets 17-15 ka glacial deposits farther north (Muffler and others, 1994). The flow may be of Holocene age, but is more likely to be about $15-12$ ka. $\mathbf{0 . 1}$

8.6 Unimproved dirt road leads left (north) 0.5 mile to another part of the inconspicuous, agglutinated spatter rampart in the vent area of the tholeiitic basalt of Calif. Hwy 44. 0.4

9.0 Cross over yellow cattle guard and turn right (southeast) on U.S. Forest Service Road 32N92Y. 0.2

9.2 Cross from tholeiitic basalt of Calif. Hwy 44 onto block-lava flows of basaltic andesites of Prospect Peak ( $\sim 57$ percent $\mathrm{K}_{2} \mathrm{O}$ content). Some of these flows contain olivine, augite, and orthopyroxene, thus capturing the reaction of olivine and melt to form orthopyroxene. This reaction generally occurs in the Lassen suite at about 56 percent $\mathrm{SiO}_{2} . \mathbf{0 . 2}$

9.4 Boundary of Swains Hole quadrangle with Prospect Peak quadrangle to the south. $\mathbf{0 . 7}$

10.1 Good exposure of basaltic andesites of Prospect Peak. $\mathbf{0 . 4}$
10.5 Intersection with U.S. Forest Service Roads 32N82Y (to left) and 32N44 (to right). $\mathbf{0 . 5}$

11.0 Pass from basaltic andesite of Prospect Peak onto the unit "till, younger glaciations" (fig. 11) mantled by ash from Cinder Cone (1666 C.E.). This young till was deposited by a lobe of ice extending north from Lassen Volcanic National Park and the Caribou Wilderness area down the valley of Butte Creek. 0.4

11.4 Turn right on U.S. Forest Service Road 32N21 south towards Butte Lake and Lassen Volcanic National Park. The road junction is on the young till just west of Butte Creek; the till extends $\sim 0.7 \mathrm{~km}$ north of the junction. As one proceeds south on this road towards LVNP, the ground surface is covered by an increasingly thick layer of dark-gray ash erupted from Cinder Cone in 1666 C.E. 1.4

12.8 Junction to left with U.S. Forest Service Road 32N09 that leads to Pole Springs Road. Continue south on U.S. Forest Service Road 32N21. The road is on young till, but just to the right of the road are heavily glaciated outcrops of the basalt of Bathtub Lake ( $\sim 400 \mathrm{ka}$ ), a unit of the Sunrise Peak sequence of the Caribou Volcanic Field. Similar outcrops overlain by till are seen on both sides of the road from here south to Butte Lake. 0.3

13.1 Boundary of Lassen Volcanic National Park. The ash from Cinder Cone is about $30 \mathrm{~cm}$ thick in this area. $\mathbf{1 . 8}$

14.9 Stop G-3: Campground and picnic ground at Butte Lake in Lassen Volcanic National Park. Immediately across the lake is the flow margin of the Fantastic Lava Beds flow; its vent, at Cinder Cone, is out of sight through the trees to the right. The summit of Cinder Cone can be accessed via a 1.8-mile trail starting at the west side of the parking lot. From this trail, one can see the flow margin of the Fantastic Lava Beds flow and patches of white diatomite that underlie the flow. Continuing on the trail provides views of the Old Bench and Painted Dunes lava flows. Ascending the trail up Cinder Cone provides spectacular views of the Painted Dunes and much of the rest of LVNP.

Cinder Cone, part of the younger Twin Lakes sequence of the Lassen domefield, has received considerable attention in the literature since its initial description by Harkness (1875) and the careful study by Diller (1891) and has been the subject of considerable controversy concerning its age and eruptive history (see, for example, Finch and Anderson, 1930; Finch, 1937). Miners claimed to have witnessed an eruption in the winter of 1850-51, and Harkness (1875) described the eruption and promoted that date. Diller (1891) attributed the deposits to two periods of eruption, one at about 1675 C.E. and the second before about 1840 C.E. Using tree-ring studies, Finch (1937) advocated five eruptions $(1567,1666,1720,1785$, and 1850). 
Recent work by Clynne and others (2000a) and a dendrochronologic age reported by Sheppard and others (2009) demonstrate that Cinder Cone had only a single short eruption in 1666 C.E. Cinder Cone is the youngest mafic volcano in the Lassen region.

The Cinder Cone eruption produced five lava flows of basaltic andesite to andesite composition, two scoria cones, and a widespread ash-fall deposit (Clynne and others, 2000a, 2002; Clynne and Muffler, 2010). The ash, divided into three units by Heiken (1978), covers an area of $>200 \mathrm{~km}^{2}$ and accounts for 20 percent of the $0.36 \mathrm{~km}^{3}$ total volume of the Cinder Cone eruption. The change in ash composition (illustrated by $\mathrm{SiO}_{2}$ content) with time (proxied by height in the composite section) is shown in figure 39. The eruption began with construction of the first scoria cone, deposition of ash unit 1 , and emplacement of the Old Bench flow, followed by deposition of ash unit 2. Painted Dunes 1 and Painted Dunes 2 flows erupted during the waning phases of ash unit 2; the first scoria cone was mostly destroyed by effusion of these flows. Ash unit 3 constructed Cinder Cone itself; the Fantastic Lava Beds were erupted at the same time from the south base of the cone. Ash units 2 and 3 fell on the Old Bench flow, and ash unit 3 fell on the Painted Dunes flows. Both of these flows were still hot enough to oxidize the overlying ash to form the colorful Painted Dunes, thus demonstrating that the entire Cinder Cone sequence was produced in a single eruptive event.

Diatomite deposits bulldozed up by the flows demonstrate that the lavas flowed into and partially filled ancient Lake Bidwell (now called Butte Lake).

The ash and the flows are sparsely porphyritic basaltic andesite to andesite. The most abundant phenocryst is magnesian olivine $\left(\mathrm{Fo}_{88-90}\right)$ with inclusions of chromian spinel, accompanied by sparse plagioclase and augite. Chemical analyses document three compositional trends (two simple; one complex) from silicic to mafic compositions (fig. 39). Ash unit 1 ranges from 56 to 53.5 percent $\mathrm{SiO}_{2}$, ash unit 2 ranges from 56 to 53 percent and back to nearly 60 percent $\mathrm{SiO}_{2}$, and ash unit 3 ranges from 58 to 55 percent $\mathrm{SiO}_{2}$. Four types of inclusions are present: (1) sparse, mostly melted, granitic rocks derived from Sierran basement, (2) abundant single crystals of quartz derived from granitic rocks, (3) multicrystalline quartz derived from metamorphic veins, and (4) rare magmatic enclaves of olivine basalt with rapid growth textures.

Compositional variation of the early magmas is modeled by assimilation of granitic xenoliths (fig. 40). The compositional reversal at the boundary between ash units 2 and 3 and the subsequent decrease in $\mathrm{SiO}_{2}$ indicate mixing with a new mafic magma having the composition of the high- $\mathrm{TiO}_{2}$ quenched magmatic inclusions.

The mountains to the southeast of Stop G-3 are glaciated flows of the Caribou Volcanic Field, including the basalts of Sunrise Peak ( $393 \pm 4 \mathrm{ka})$. From Stop G-3, a cross-country scramble up the west flank of Sunrise Peak to the prominent, bare bluff (at approximately UTM 10T E0645650 N4490680 NAD27) produces a spectacular view of Cinder Cone, Lassen Peak, and Chaos Crags (cover; photograph 31 of Muffler and others, 2010).

Return north along U.S. Forest Service Road 32N21. 2.1

17.0 Turn right (east) on U.S. Forest Service Road 32N09. The road for the next 2.1 miles is on till of younger
Figure 39. Graph showing variation of $\mathrm{SiO}_{2}$ versus height (a proxy for time) in a composite ash section at Cinder Cone. The Old Bench flow was emplaced following ash unit 1. The Painted Dunes flows were emplaced during the waning stages of ash unit 2 . The Fantastic Lava Beds flows erupted concurrently with ash unit 3 . Lines indicate the stratigraphic position of the lava flows in the ash section and the range of $\mathrm{SiO}_{2}$ in the flows.

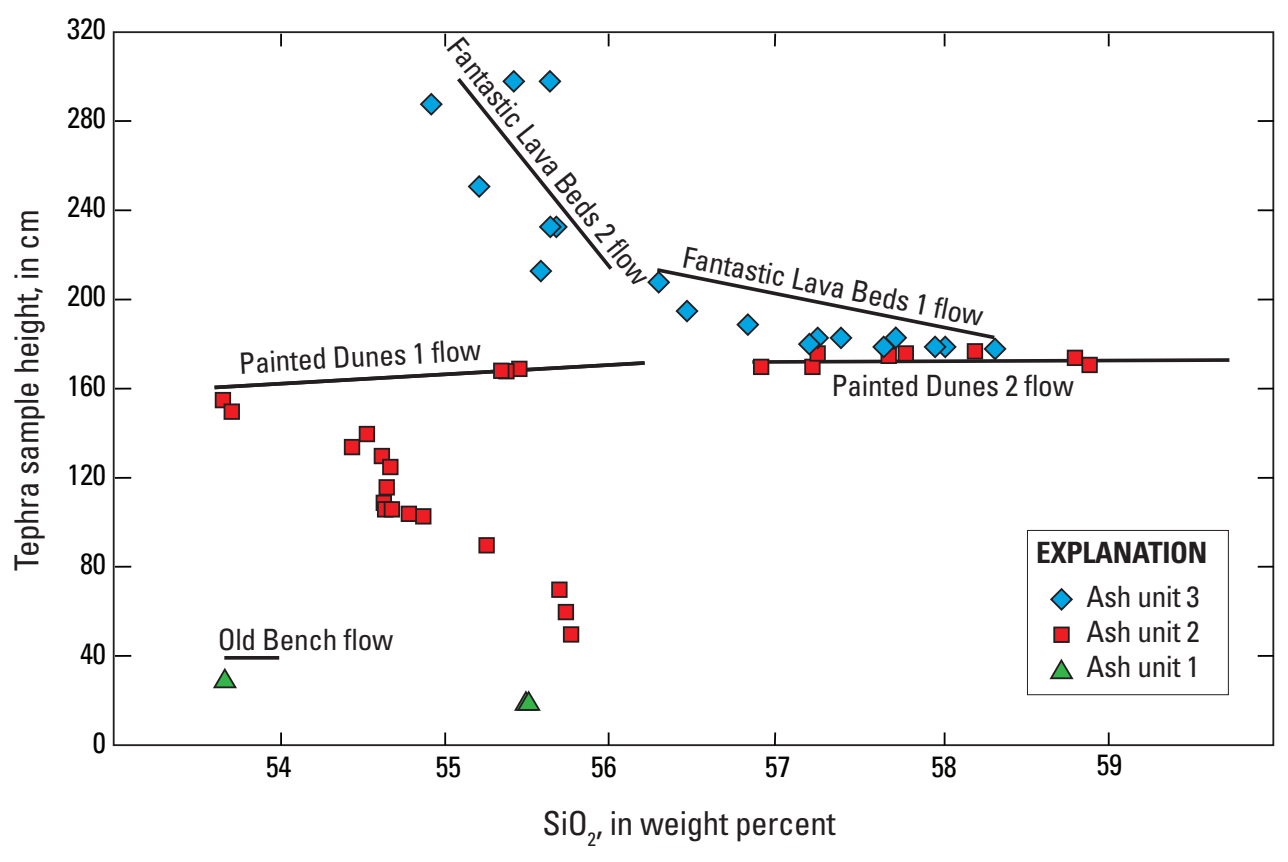


glaciations that was deposited by the lobe of ice extending north from Lassen Volcanic National Park and the Caribou Wilderness area. $\mathbf{1 . 3}$

18.3 Pole Spring is in the marshy area to left of the road. $\mathbf{0 . 8}$ 19.1 Turn left (north) on U.S. Forest Service Road 32N26. Road is on the right lateral moraine banked to the east against the unglaciated basalt of Twin Buttes (46.3 \pm 3.4 ka), part of the Bidwell Spring chain in the northern (unglaciated) part of the Caribou Volcanic Field. 0.3

19.4 Road climbs from till of younger glaciations onto the basalt of Twin Buttes. Although this large lava flow is bounded on the west by till of younger glaciations, its flow top is not glaciated. The vents for the basalt of Twin Buttes are marked by two large scoria cones (Twin Buttes) 2 mi to the southeast. 0.5

19.9 Road climbs onto the overlying basaltic andesite of section 36 , a very young ( $\sim 40-25 \mathrm{ka})$ flow in the Bidwell Spring chain of the northern Caribou Volcanic Field. The vents for this flow are two scoria cones $0.5 \mathrm{mi}$ to the southeast. $\mathbf{0 . 6}$

20.5 Junction with U.S. Forest Service Road 32N35 to the right. Continue north on U.S. Forest Service Road $32 \mathrm{~N} 26$. To the left for the next 0.5 mile are the scoria cones of the basaltic andesite of Pole Spring Road, another very young ( $45-25 \mathrm{ka}$ ) unglaciated flow of the Bidwell Spring Chain of the northern Caribou Volcanic Field. This unit overlies the lava flow of the basalt of Twin Buttes (on the right of the road). $\mathbf{0 . 5}$

21.0 For the next 0.6 mile, the road is on the basalt of hill 2109 , a calc-alkaline basalt erupted from two large scoria cones 1.5-2.0 miles to the southeast. This basalt, part of the Cone Lake chain, is much older than the flows of the Bidwell Spring chain, probably 250-225 ka. 0.3
21.3 To the left is the very young flow margin of the basaltic andesite of Pole Spring Road. 0.3

21.6 Road descends onto the tholeiitic basalt of hill 1879 ( $\sim 190 \mathrm{ka})$. This short flow, vented from a scoria cone $\sim 1$ mile to the southeast, is unusually small for tholeiitic basalt in the Lassen area. 0.9

22.5 Boundary of Prospect Peak quadrangle and Swains Hole quadrangle to the north. $\mathbf{0 . 1}$

22.6 Road is on colluvium overlying low, obscure outcrops of the basalts and basaltic andesites of Swains Hole.

This unit is poorly exposed here, but is well exposed to the north in the Butte Creek Rim. The age of the unit is poorly constrained, probably $\sim 725-600 \mathrm{ka} . \mathbf{0 . 7}$

23.3 Boundary of Swains Hole quadrangle and Poison Lake quadrangle to the east. $\mathbf{0 . 7}$

24.0 Intersection of U.S. Forest Service Road 32N26 with Calif. Hwy 44 at mile 10.3 of road log from Hat Creek Rim overlook to Chester (Section F).

\section{Section H: Intersection of Calif. Hwys 44 and 89 at the northwest entrance to Lassen Volcanic National Park west to Anderson}

0.0 Section $\mathrm{H}$ starts at the end of Section D and the beginning of Section E. Roadcuts at the intersection of Calif. Hwys 44 and 89 expose the pumiceous pyroclasticflow deposits derived from Eagle Peak (66 $\pm 4 \mathrm{ka})$. Drive west on Calif. Hwy 44 towards Redding. The highway heads down the ancestral drainage of Manzanita Creek, which contains the upper pyroclastic flow of Chaos Crags. This ancestral drainage was blocked by the landslide of Chaos Jumbles $\sim 350$ years ago.
Figure 40. Harker diagram showing variation of $\mathrm{TiO}_{2}$ versus $\mathrm{SiO}_{2}$ for the array of compositions at Cinder Cone. The mixing line between the composition of the Old Bench flow and ash unit 1 and the composition of the granitic inclusions indicates that variation is caused primarily by assimilation of up to 30 percent of granite. The composition of Devonian granite exposed $20 \mathrm{~km}$ to the south is a proxy for the granite composition. Quenched inclusions with higher $\mathrm{TiO}_{2}$ indicate that a second mafic magma also interacted with granite to produce the array of Fantastic Lava Beds and ash unit 3 compositions.

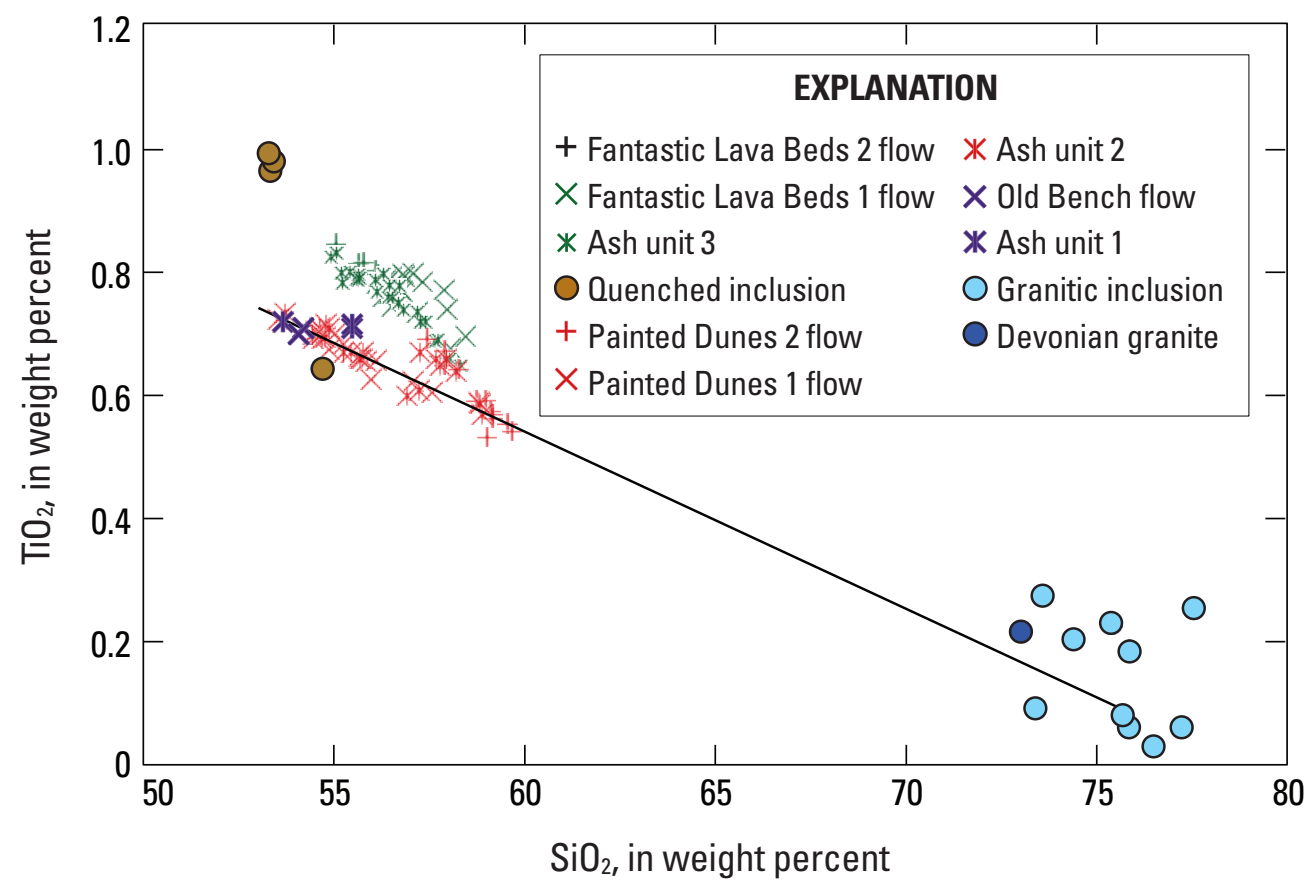


Manzanita Creek now flows in a channel approximately 0.5 mile to the south of the road. $\mathbf{0 . 3}$

0.3 Roadcuts along the next few miles expose a complex stratigraphy of rocks from the Lassen Volcanic Center and regional volcanoes. The bouldery deposit on the right is the avalanche deposit from the dacite dome of hill 8283, located just northwest of Lassen Peak. The dacite of hill $8283(261 \pm 5 \mathrm{ka})$ is part of the Bumpass sequence. The avalanche occurred some time between 260 and $200 \mathrm{ka} . \mathbf{0 . 1}$

0.4 Roadcuts, primarily on the right, expose a thick and widespread two-pyroxene andesite lava flow, the 450-425 ka andesite of Manzanita Creek, part of the Diller sequence of Brokeoff Volcano. The vent for this andesite is marked by a scoria cone just southeast of Manzanita Lake. 0.7

1.1 The gravel road to the left (U.S. Forest Service Road 17) leads south to the town of Mineral, approximately following the western boundary of the Lassen Volcanic Center. Many good exposures of rocks related to Brokeoff Volcano, the Maidu Volcanic Center, and glacial deposits can be seen along this route. In addition to the rocks described at mile 0.3, the pyroclastic flow from Eagle Peak $(66 \pm 4 \mathrm{ka})$, a tuff deposit of lithic material from the formation of the nearby phreatic explosion crater called Deep Hole ( $\sim 200 \mathrm{ka})$, and another rhyodacite pyroclastic flow whose origins are obscure are all exposed in the first roadcut, approximately $50 \mathrm{~m}$ south of Calif. Hwy 44. $\mathbf{0 . 3}$

1.4 Roadcuts in augite-olivine basaltic andesite lava flows from Red Lake Mountain ( $75 \mathrm{ka}) . \mathbf{0 . 8}$

\section{Stop H-1: Roadcut exposing complex volcanic} stratigraphy west of Manzanita Lake. At the

base of this new roadcut is the 450-425-ka, twopyroxene andesite of Manzanita Creek (discussed at mile 0.4 ). The lava flow is deeply weathered and has a thick soil. Locally preserved on top of the soil is the lithic tuff deposit from the formation of Deep Hole (discussed at mile 1.1). The lithic tuff in this new roadcut is only a few cm thick and consists of lithic lapilli, mostly $<5 \mathrm{~mm}$, of andesite of Viola. The overlying surge deposits consist of dark, crystal-rich, bedded tuff containing abundant augite and olivine and are about $50 \mathrm{~cm}$ thick in this roadcut. The surge deposits are slightly older than the lava flows from Red Lake Mountain ( $75 \mathrm{ka}$ ) but younger than the formation of Deep Hole. Their source is unknown but must have been close by and might be related to the Red Lake Mountain volcano. Directly overlying the surge deposits are lava flows of the basaltic andesite of Red Lake Mountain. Basal and flow-top breccias enclosing a dense, massively jointed flow core are well exposed (fig. 41). 0.2

2.4 The flat on both sides of the highway is underlain by the avalanche deposit from the dacite dome of hill $8283(261 \pm 5 \mathrm{ka})$ and by pyroclastic flows from Eagle Peak (66 \pm 4 ka). Manzanita Creek rejoins its ancestral channel on the south side of this flat area. White pumice from the upper pyroclastic flow of Chaos Crags (1,103 \pm 13 B.P.) covers the surface of the flat. 0.6

3.0 Boundary of Manzanita Lake quadrangle with Viola quadrangle to the west. $\mathbf{0 . 2}$

Figure 41. Photograph of roadcut exposing complex volcanic stratigraphy west of Manzanita Lake at mile 2.2 of Section H. Highly weathered andesite of Manzanita Creek (450-425 ka) is overlain by the lithic tuff deposit from the formation of Deep Hole (see inset). This thin, discontinuous unit is overlain by about $50 \mathrm{~cm}$ of bedded surge deposits, possibly associated with the eruption of the basaltic andesite of Red Lake Mountain ( 75 ka). Top of roadcut exposes both the flow-top and basal breccias of the basaltic andesite of Red Lake Mountain as well as its dense flow core.

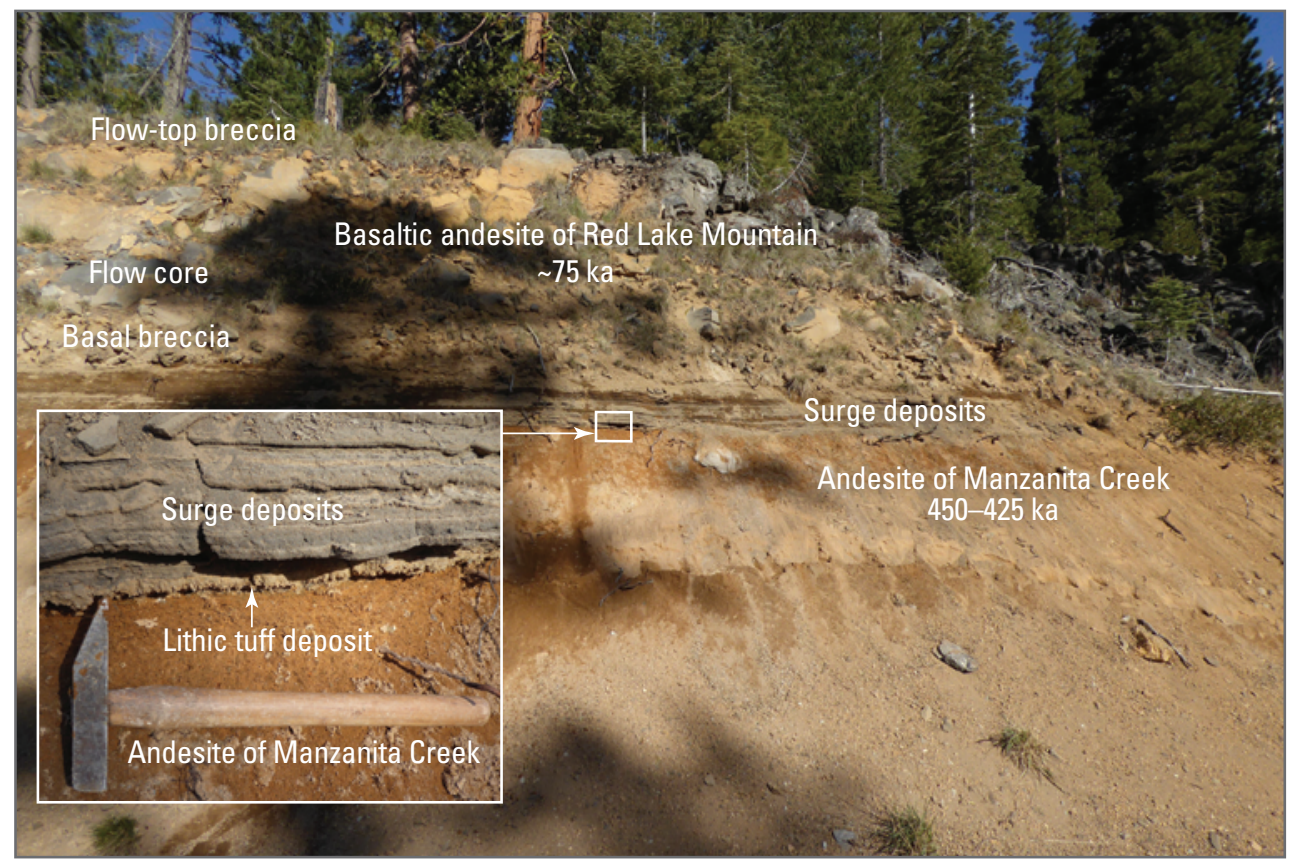


3.2 Cliffs above the highway on the right are lava flows from Red Lake Mountain. Highway is on the andesite of Viola, a $313 \pm 8$ ka lava flow of the older Twin Lakes sequence of the Lassen Volcanic Center. This flow is the oldest of the hybrid andesite lava flows of the Lassen domefield. Its vent is 3 miles southeast. The upper pyroclastic flow of Chaos Crags crops out sporadically along Manzanita Creek, just to the left of the highway. 0.8

4.0 Roadcuts on the right are in andesite of Viola. $\mathbf{0 . 5}$

4.5 To the right of the highway in the Manzanita Creek drainage, bulldozing has exposed a thin, white veneer of the upper pyroclastic flow of Chaos Crags. This unit can be traced west along Manzanita Creek for at least 3.5 miles to McCumber Flat, the last 2 miles as a lahar. For the next 1.3 miles, Calif. Hwy 44 is on the upper surface of the andesite of Viola. 1.3

5.8 For the next 0.3 mile, the highway lies on andesites of the Diller sequence of Brokeoff Volcano. $\mathbf{0 . 3}$

6.1 Slope to left of highway is the toe of the andesite of Viola. 0.3

6.4 Lassen Pines Christian Camp at the junction with the road southeast to Brokeoff Meadows and the road south to Mineral. Settlement of Viola is just south of the junction. The flat for the next few miles along Calif. Hwy 44 is formed by glacial outwash that consists of material transported by streams from the terminal moraine complexes of glaciers in the Manzanita and Bailey Creek drainages. 0.4

6.8 Deer Flat Road to right. $\mathbf{0 . 8}$

7.6 Good view back towards the east of Brokeoff Mountain and Mount Diller, the major remnants of the western flank of Brokeoff Volcano. 1.0

8.6 Rock Creek Road to left leads to the community of Manton. 0.3

8.9 Long Hay Flat Road to left also leads to Manton. $\mathbf{1 . 2}$

10.1 Boundary of Viola quadrangle with Hagaman Gulch quadrangle to the west. $\mathbf{0 . 1}$

10.2 North Fork Battle Creek. For the next several miles the highway travels over the tholeiitic basalt of Eagle Canyon. This LKOT lava flow erupted from a vent near Manzanita Lake, and its age is $199 \pm 22 \mathrm{ka}$. The lava flowed south over the Battle Creek Fault scarp but is not offset, indicating that the fault has been inactive for at least $200 \mathrm{ka}$, and probably closer to $500 \mathrm{ka} . \mathbf{0 . 1}$

10.3 Lake McCumber Road. 2.0

12.3 Satellite Pines. Just ahead is a good roadcut in tholeiitic basalt of Eagle Canyon. 0.5

12.8 Ritts Mill Road. 0.6

13.4 Airport Way. 1.0

14.4 Mt. Lassen Woods. 0.2

14.6 Rest Stop. $\mathbf{0 . 4}$

15.0 For the next 0.5 mile, Calif. Hwy 44 descends a gentle slope that marks the western edge of the tholeiitic basalt of Eagle Canyon. 0.5

15.5 Millseat Creek marks the contact between tholeiitic basalt of Eagle Canyon and older tholeiitic basalt flows collectively called the basalt of Coleman Forebay (Blake and others, 1999). ${ }^{40} \mathrm{Ar} /{ }^{39} \mathrm{Ar}$ dates on these basalts are $949 \pm 22,948 \pm 28$, and $778 \pm 43 \mathrm{ka}$ (M.A. Lanphere, written commun., 1997). Vent locations are to the northeast, probably buried by younger lavas. The soil on the basalt of Coleman Forebay is several meters thick, whereas the soil on the basalt of Eagle Canyon (199 $\pm 22 \mathrm{ka})$ is only a few tens of centimeters thick. Millseat Creek, in great part, is fed by springs that emerge from the base of the basalt of Eagle Canyon. Boundary of Hagaman Gulch quadrangle with Manton quadrangle to the south. $\mathbf{1 . 5}$ Boundary of Manton quadrangle with Shingletown quadrangle to the west. $\mathbf{0 . 6}$

17.6 Town of Shingletown. To left, Wilson Hill road leads down over the Battle Creek Fault scarp and connects with roads to the community of Manton. 0.7

18.3 Pass from basalt of Coleman Forebay onto older regional calc-alkaline andesites and basaltic andesites. These rocks form a platform of normally faulted and eroded lava flows erupted from numerous small vents. Ages are poorly known but probably range from $1 \mathrm{Ma}$ to possibly as old as 3.5 Ma. 0.4

18.7 Pass from regional calc-alkaline andesites and basaltic andesites back onto the basalt of Coleman Forebay. 0.4

19.1 Shasta Forest Drive. Pass from the basalt of Coleman Forebay back onto regional calc-alkaline andesites and basaltic andesites. 0.5

19.6 Boundary of Shingletown quadrangle with Inwood quadrangle to the north. $\mathbf{0 . 4}$

20.0 Roadcuts on both sides of the highway expose regional andesites and basaltic andesites. Over the next 11.5 miles, the highway passes over more of these andesites as well as the basalt of Coleman Forebay. $\mathbf{0 . 3}$

20.3 Basalt of Coleman Forebay. $\mathbf{0 . 6}$

20.9 To the north (right) along Ponderosa Way are found outcrops of the Tuscan Formation (3.5-2.5 Ma), in this region probably derived from the Latour Volcanic Center and (or) other unknown sources to the northeast. Within the Tuscan Formation is the Nomlaki Tuff Member ( 3.3 Ma), a thick dacitic ash-flow tuff of regional extent that may also have erupted from the Latour Volcanic Center. One can follow Ponderosa Way 2.1 mi north and then turn left (west) for 0.8 mile to Bear Creek Falls, where the Nomlaki Tuff is densely welded and $>100 \mathrm{~m}$ thick; it probably was ponded in a canyon. $\mathbf{0 . 5}$

21.4 Basalt of Coleman Forebay along road, with hills to left being older regional andesites and basaltic andesites. $\mathbf{0 . 1}$

21.5 Power line. $\mathbf{1 . 5}$

23.0 Pine Bluff Road. Pass from basalt of Coleman Forebay onto Tuscan Formation. Boundary of Inwood quadrangle with Shingletown quadrangle to the south, just south of settlement of Midway. $\mathbf{0 . 2}$

23.2 Pass from Tuscan Formation onto basalt of Coleman Forebay. 0.4 
23.6 Boundary of Shingletown quadrangle with Inwood quadrangle to the north. Still basalt of Coleman Forebay. 0.6

$24.2 \quad$ Black Butte Road. 0.5

24.7 Boundary of Inwood quadrangle with Clough Gulch quadrangle to the west. $\mathbf{0 . 1}$

24.8 Inwood Road. $\mathbf{1 . 5}$

26.3 Turn left from Calif. Hwy 44 onto Dersch Road. 1.2

27.5 Boundary of Clough Gulch quadrangle with Tuscan Buttes NE quadrangle to the south. For the next 5.6 miles, the road traverses a series of poorly understood tholeiitic basalts, mapped by Blake and others (1999) as the basalt flows of Shingletown Ridge but probably equivalent to the basalt of Coleman Forebay. 1.9

29.4 Bridge over Lack Creek. 0.8

30.2 To the left is Ash Creek Road. Bear right and continue west on Dersch Road. 2.5

32.7 Boundary of Tuscan Buttes NE quadrangle with Balls Ferry quadrangle to the west. $\mathbf{0 . 5}$

33.2 Bridge over Lack Creek. Drop down from basalt onto Tuscan Formation. Hills to the right are Tuscan Formation. Flats to the left are gravels of the Pleistocene Riverbank Formation. 0.9

34.1 Bridge across Bear Creek. Bluffs on west side of creek are tholeiitic basalts, mapped by Blake and others (1999) as the basalt flows of Shingletown Ridge. $\mathbf{0 . 2}$

34.3 For the next 2 miles, the road is just south of the Bear Creek Fault, a minor east-trending fault that uplifts Tuscan Formation and Riverbank Formation to the north. The Riverbank Formation consists of gravel, sand, silt, and clay of Pleistocene age (Blake and others, 1999). 2.0

36.3 Parkville Road to left. $\mathbf{0 . 8}$

37.1 Bridge over Dry Creek. West of Dry Creek, the road climbs onto a bench of Red Bluff Formation and overlying Riverbank Formation, both underlain by the much older Tuscan Formation. Here, the Red Bluff Formation is a coarse gravel with a characteristic red color (Blake and others, 1999). 0.9

38.0 Road drops through roadcuts of Red Bluff and Riverbank Formations to Cow Creek. $\mathbf{0 . 3}$

38.3 Bridge over Cow Creek. From here to the end of the road $\log$ at I-5, the road traverses various Pleistocene and Holocene sediments of the northern Sacramento Valley. 0.7

39.0 Four-way stop at blinking red light. Turn left onto Deschutes Road. 1.0

$40.0 \quad$ Bridge over Sacramento River. 0.8

40.8 Boundary of Balls Ferry quadrangle with Cottonwood quadrangle to the west. $\mathbf{1 . 4}$

42.2 Sharp right bend at sawmill. $\mathbf{0 . 9}$

43.1 Pass under Interstate 5. 0.3

43.4 Stoplight. Turn left onto Calif. Hwy 273 (old Calif. Hwy 99), which leads south to Interstate 5. 0.2

43.6 Stoplight. Continue straight. $\mathbf{0 . 5}$

44.1 Merge with I-5 south to Red Bluff.

\section{Section I: Old Station to Burney}

0.0 Junction of Calif. Hwys 89 and 44. Proceed north on Calif. Hwy 89. 0.3

0.3 Turnoff to right leads to Subway Cave, a U.S. Forest Service exhibit that allows exploration of part of a lava tube in the Hat Creek Basalt. For the next 17 miles, Calif. Hwy 89 lies primarily on the Hat Creek Basalt, at $24 \pm 6$ ka the youngest volcanic rock in the north-trending Hat Creek Graben (fig. 42). This LKOT lava erupted from a 3-km-long spatter rampart (see Section E, Stop E-1) located just south of Old Station (fig. 42) and flowed in lava tubes for nearly 20 miles $(32 \mathrm{~km})$ to the north. The flow covered $\sim 100 \mathrm{~km}^{2}$, is as thick as $50 \mathrm{~m}$ along the axis of the Hat Creek Graben, and has a volume of $\sim 2.5 \mathrm{~km}^{3}$.

To the right is the Hat Creek Fault (see Stop E-2). According to Blakeslee and Kattenhorn (2013), the Hat Creek Fault is composed of three subparallel systems of scarps of different ages that accrued a cumulative throw in excess of $600 \mathrm{~m}$ (see also Muffler and others, 1994, and Walker, 2008). The oldest and largest system of scarps, referred to as the Rim Scarp, has as much as $350 \mathrm{~m}$ of throw and defines the easternmost extent of the fault system. A lava flow at the top of the footwall has a $\mathrm{K}-\mathrm{Ar}$ age of $924 \pm 24 \mathrm{ka}$ (Clynne and Muffler, 2010), thus constraining the maximum age of the fault system (Blakeslee and Kattenhorn, 2013). The fault scarps of intermediate age west of the Rim Scarp are referred to by Blakeslee and Kattenhorn (2013) as the Pali Scarp and have accrued as much as $\sim 175 \mathrm{~m}$ of throw (Walker, 2008). The youngest system of scarp segments, referred to by Blakeslee and Kattenhorn (2013) as the Active Scarp, has a maximum throw of $56 \mathrm{~m}$ and exhibits evidence of repeated earthquake activity since the late Pleistocene (fig. 43).

To the left is the rugged edifice of the andesite of Sugarloaf Peak (46 \pm 7 ka; Turrin and others, 2007), the most prominent volcano of the Sugarloaf chain (fig. 42). Units of the Sugarloaf chain bury young faults on the west boundary of the Hat Creek Graben. 3.6

3.9 Calif. Hwy 89 crosses Hat Creek and passes from the Hat Creek Basalt onto an outlier of the older andesitic rocks that form the west rim of the Hat Creek Graben. 1.2

5.1 Rocks to the left of the road for the next 1.1 miles are units of the Sugarloaf chain. The cones adjacent to the road are the andesite of hill 4041 and the andesite of Calif. Hwy 89, whereas the large volcano to the south is the andesite of Sugarloaf Peak. 1.6

6.7 After crossing a small patch of alluvium, the highway returns to the Hat Creek Basalt. In the right distance is the valley of Lost Creek, which cuts a prominent canyon through the Hat Creek Rim. The water in Lost Creek is derived by underground flow from Butte Creek (east of the Hat Creek Rim) and ultimately from 


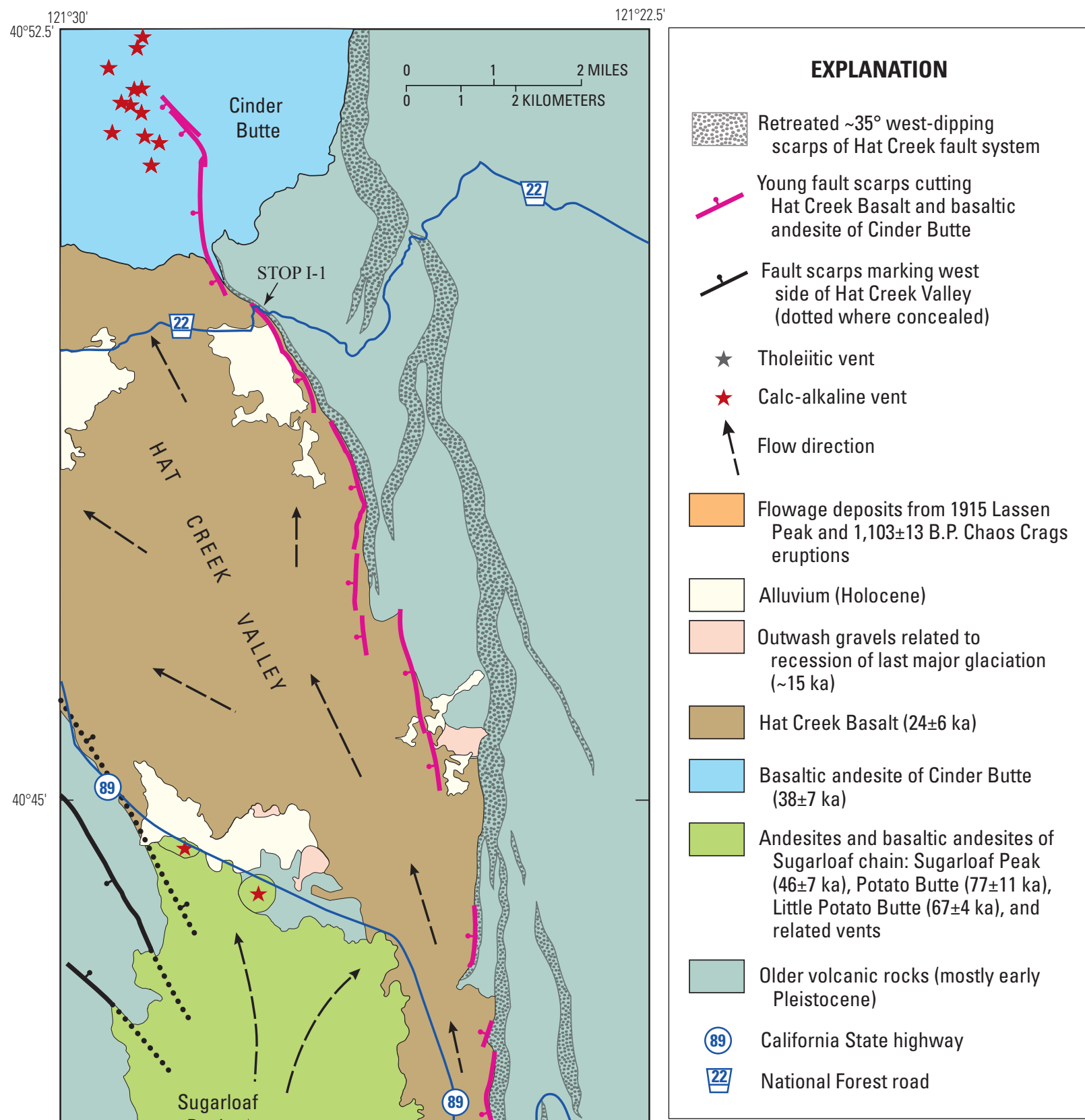

Figure 42. Generalized geologic map of the northward-flowing Hat Creek Basalt. Adapted from Turrin and others (2007). 
the eastern part of Lassen Volcanic National Park. In this area, the Hat Creek Basalt is overlain by $\sim 15-\mathrm{ka}$ gravel deposits that are related to the end of the last major glaciation. These gravels are displaced $\sim 20 \mathrm{~m}$ across the Active Scarp of the Hat Creek Fault (Muffler and others, 1994). Despite this conspicuous evidence of young faulting, modern seismicity in this area is low and diffuse (LaForge and Hawkins, 1986; Waldhauser and Schaff, 2008; see also figure 3 of Blakeslee and Kattenhorn, 2013). The Hat Creek Fault has produced no large historical earthquakes (Blakeslee and Kattenhorn, 2013).

The ridge to the left (west) of the highway consists of older andesitic rocks and separates the Hat Creek Basalt from a north-trending belt of quite young volcanic rocks, as yet undated. $\mathbf{0 . 2}$

6.9 Boundary of Old Station quadrangle with Murken Bench quadrangle to the north. $\mathbf{1 . 3}$

8.2 Boundary of Murken Bench quadrangle with Burney Mountain East quadrangle to the west. 2.7

10.9 Turn right (east) onto U.S. Forest Service Road 6R200 (Doty Road), still on Hat Creek Basalt. 0.9

11.8 Cross Hat Creek. 0.4

12.2 Turn right onto U.S. Forest Service Road 6R201 (also known as U.S. Forest Service Road 22 and Bidwell
Road) and continue east across Hat Creek Basalt. 0.1

12.3 Boundary of Burney Mountain East quadrangle with Murken Bench quadrangle to the east. 1.7

14.0 Road to right (south) leads to the University of California Radio Observatory. 0.5

14.5 At T junction, turn left. $\mathbf{0 . 3}$

14.8 Stop I-1: Active Scarp of the Hat Creek Fault. See figures 42 and 43 for location, figure 44 for photographic view. The Active Scarp of the Hat Creek Fault is not just a simple disruption of the Hat Creek Basalt along a vertical fault. A succinct summary of the near-surface fault features is presented by Blakeslee and Kattenhorn (2013, p. 1402; see also their figure 6):

The Active Scarp is also characterized by a hanging wall fault-trace monocline, representing the near-surface flexing of the Hat Creek Basalt above an upwardpropagating fault tip prior to initial surface breaching by the fault.

Along the Active Scarp, the monocline accounts for as much as $33 \mathrm{~m}$ of throw (Walker, 2008), implying numerous fault slip events prior to breaching of the surface along

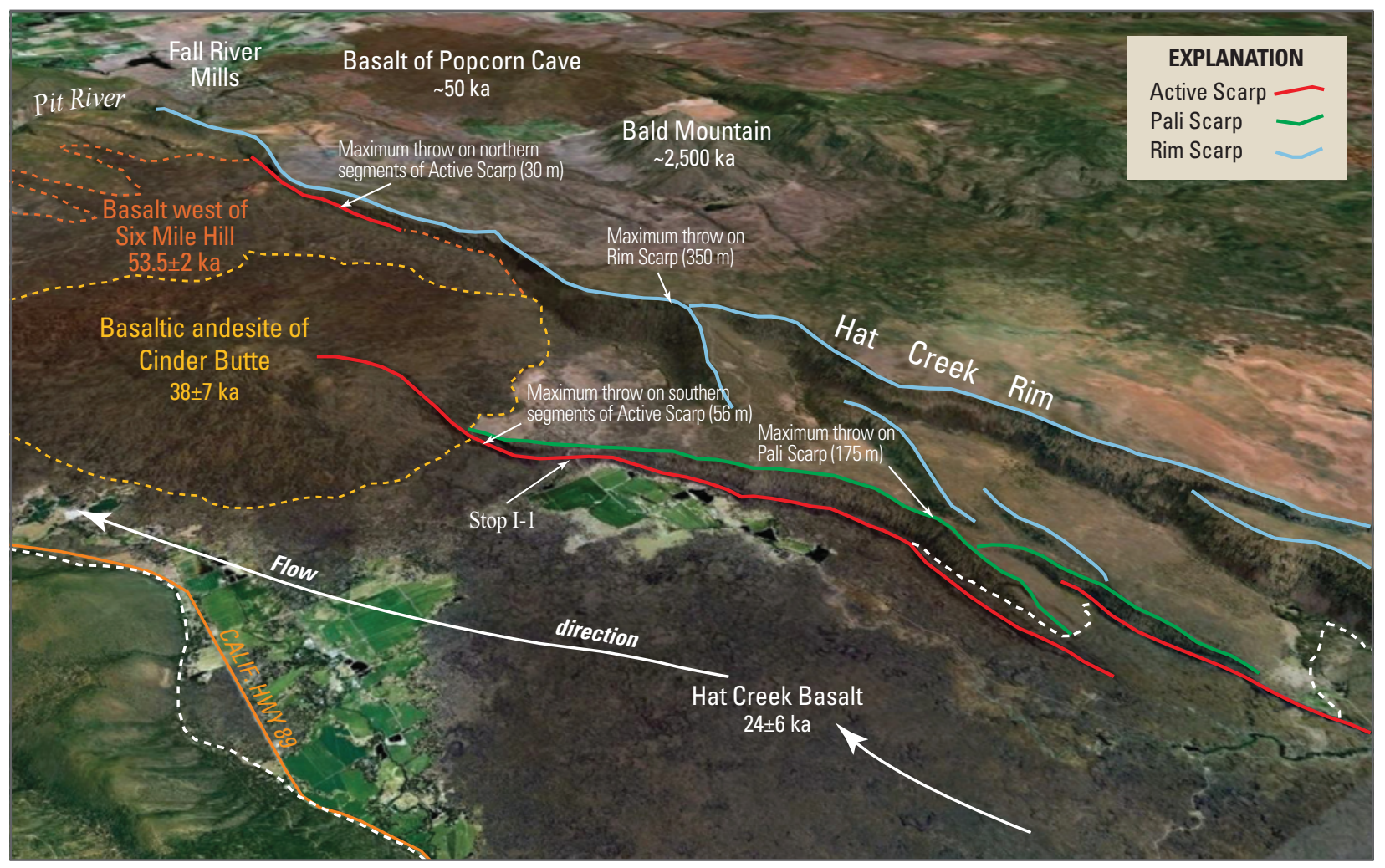

Figure 43. Oblique satellite image with perspective view down and to the northeast of the northern part of the Hat Creek Fault. The Active Scarp is shown in red, the Pali Scarp in green, and the Rim Scarp in blue; fault lines are drawn at the top of the scarps. Dashed orange line is the margin of the basalt west of Six Mile Hill, dashed yellow line is the margin of the basaltic andesite of Cinder Butte, and dashed white line is the margin of the Hat Creek Basalt. Figure is adapted from figure 5 of Blakeslee and Kattenhorn (2013). 
the upper hinge line of the fold. Once the surface was breached by the fault, monocline growth ceased, and all subsequent surface throw accumulation was directed along the vertical scarp.

Progressive disaggregation of the monocline occurred along the Active Scarp in response to the local effects of repeated fault rupture, with the final stage of monocline history being its complete collapse, rendering the monocline to a pile of rubble...commonly composed of intact columns of basalt...

Comprehensive descriptions of the various surface features of the Active Scarp are presented by Walker (2008), along with detailed maps of the fault traces prepared by Marie Jackson for several parts of the fault trace.

Turn around and retrace route to mile 12.2. 2.5

17.3 At T-junction, turn right on U.S. Forest Service Road 6R200 (Doty Road). 0.7

18.0 Cross Hat Creek. $\mathbf{0 . 2}$

18.2 At T junction, turn right (north) on Calif. Hwy 89. Highway is on the Hat Creek Basalt, but steep hills just to the left (west) of the highway are much older (early to middle Pleistocene?) andesites. The prominent, rugged volcanic edifice to the northeast is the basaltic andesite of Cinder Butte $\left({ }^{40} \mathrm{Ar} /{ }^{39} \mathrm{Ar}\right.$ age of $38 \pm 7 \mathrm{ka}$; Turrin and others, 2007). 1.7
19.9 Highway crosses Hat Creek. 1.6

21.5 Highway crosses Hat Creek and passes along the contact between alluvium to the right and the toe of the late Pleistocene basalt of Doyles Corner, one of the units in the belt of the young lava flows that lies west of the early to middle Pleistocene(?) andesites that form the west rim of the Hat Creek Graben. The vent for the basalt of Doyles Corner is 2 miles to the southwest. $\mathbf{0 . 5}$

22.0 Boundary of Burney Mountain East quadrangle with Cassel quadrangle to the north. $\mathbf{0 . 3}$

22.3 Doyles Corner. Road 7R01 (Cassel Road) to the right leads along Hat Creek to the town of Cassel. Rising River, a large tributary of Hat Creek at the toe of the Hat Creek Basalt, is 2.5 miles northeast of Doyles Corner. Rising River is fed primarily by water flowing from beneath and within the Hat Creek Basalt. 0.3

22.6 Highway passes from alluvium across a fault scarp onto the tholeiitic basalt of Rocky Ledge (197 8 ka; weighted average of three ${ }^{40} \mathrm{Ar}{ }^{\beta 9} \mathrm{Ar}$ determinations by A.T. Calvert, written commun.). This unit is one of three tholeiitic basalts that are monotonously similar in appearance and cannot be distinguished readily one from another in the field or petrographically. They are, however, quite distinctive in age, paleomagnetic direction, and major-element composition (Muffler and others, 2012), allowing robust discrimination of the tholeiitic basalt of Rocky Ledge, the tholeiitic basalt of Rock Spring $(545.7 \pm 6.7 \mathrm{ka})$, and the tholeiitic basalt of Sam Wolfin Spring $(647.3 \pm 21.7 \mathrm{ka})\left({ }^{40} \mathrm{Ar} /{ }^{39} \mathrm{Ar}\right.$ determinations by
Figure 44.

Annotated photograph from Stop I-1 looking south along the Active Scarp of the Hat Creek Fault.

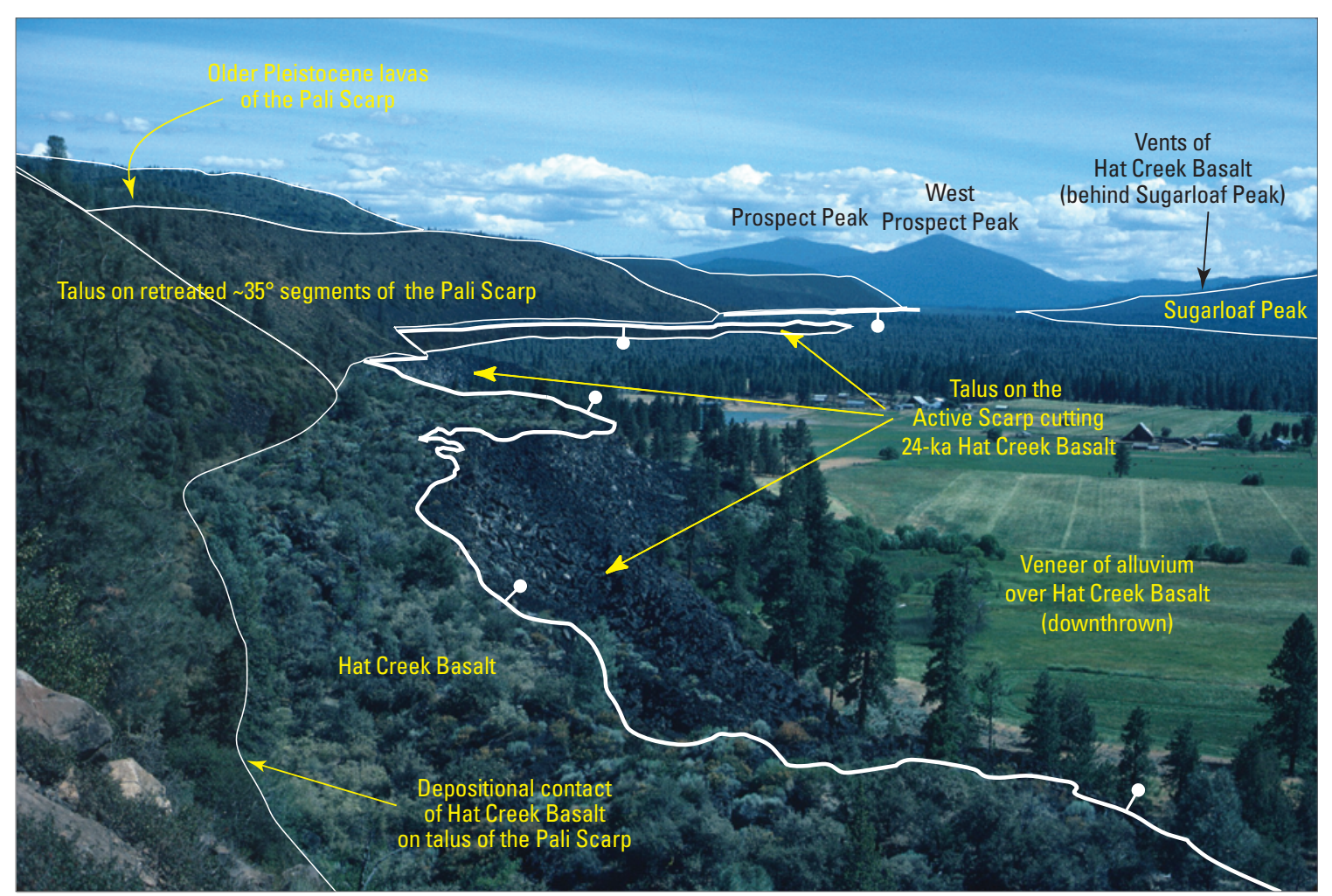


A.T. Calvert, written commun.). These tholeiitic units are overlain to the east by the calc-alkaline basalt west of Six Mile Hill $\left(53.5 \pm 2.0 \mathrm{ka} ;{ }^{40} \mathrm{Ar} /{ }^{39} \mathrm{Ar}\right.$ determination by A.T. Calvert, written commun.) and to the south by the tholeiitic Hat Creek Basalt ( $24 \pm 6 \mathrm{ka})$ and the calcalkaline basaltic andesite of Cinder Butte $(38 \pm 7 \mathrm{ka}$; both ages from Turrin and others, 2007).

The tholeiitic basalts in the northern part of the Hat Creek Graben inundated low topography between higher-elevation remnants of $>1$-Ma calc-alkaline volcanoes. Tholeiitic basalts have a wider areal extent than calc-alkaline edifices and thus serve as important regional stratigraphic markers. Their upper surfaces, having little relief, also provide strain markers useful for measuring fault offsets and estimating times between significant earthquakes. $\mathbf{0 . 2}$.

22.8 Intersection on left with a gravel road (Mountain View Road) that leads south for a mile and then west five miles to the town of Burney.

Calif. Hwy 89 continues northwest on the flat upper surface of the tholeiitic basalt of Rocky Ledge. 2.3

25.1 The mountain to the right, Brush Mountain, is a complex, faulted calc-alkaline volcano probably $\sim 2.5 \mathrm{Ma}$ in age. Surprisingly, the summit of the mountain consists of a much younger basalt plug and basaltic andesite cinder cone, perhaps $\sim 50 \mathrm{ka}$ in age. 2.0

27.1 Four-way stop at a busy, major highway intersection. Calif. Hwy 89 continues straight across the tholeiitic basalt of Rocky Ledge to McArthur-Burney Falls Memorial State Park (6 miles), across the Pit River, and eventually to Interstate 5 at the city of Mt. Shasta. Calif. Hwy 299 to the right leads northeast across the
Pit River to Fall River Mills and eventually to Alturas.

Turn left on Calif. Hwy 299 towards Burney. 0.7

27.8 Calif. Hwy 299 crosses the prominent scarp of the Rocky Ledge Fault, which displaces the tholeiitic basalt of Rocky Ledge $\sim 100$ feet vertically. The northeast end of the roadcut consists of the tholeiitic basalt of Rocky Ledge, whereas the southwest part of the roadcut consists of much older underlying calc-alkaline basalt. $\mathbf{0 . 3}$

$28.1 \quad$ Stop I-2: Tholeiitic basalt of Rocky Ledge overlying much older calc-alkaline basaltic andesite. Pulloff on the right allows safe parking for several vehicles (do not block the chain barrier).

Cross Calif. Hwy 299 with very great care to avoid high-speed vehicles, particularly trucks. Walk 300 feet through brush to the east lip of the roadcut of Calif. Hwy 299, where one can see the contact (fig. 45) between the tholeiitic basalt of Rocky Ledge (197 $\pm 8 \mathrm{ka})$ and the underlying kipuka of calcalkaline basalt $\left(2,740 \pm 110 \mathrm{ka} ;{ }^{40} \mathrm{Ar} /{ }^{39} \mathrm{Ar}\right.$ determination by P.R. Renne, written commun., 1993).

Walk back to Calif. Hwy 299 and, once again, be very aware of fast-moving traffic when crossing the highway. Continue southwest on Calif. Hwy 299. 0.5

28.6 Pass through community of Johnson Park. 0.2

28.8 Boundary of Cassel quadrangle with Burney quadrangle to the west. 2.2

31.0 Black Ranch Road (7P200) to the right. 0.7

31.7 Prominent stop light in the town of Burney. To the left is Mountain View Road, which after 1.6 miles becomes a gravel road leading east 4 miles farther to an intersection with Calif. Hwy 89, 0.5 miles northwest of Doyles Corner.
Figure 45. Photograph at Stop I-2 looking north across Calif. Hwy 2990.5 mile northeast of Johnson Park.

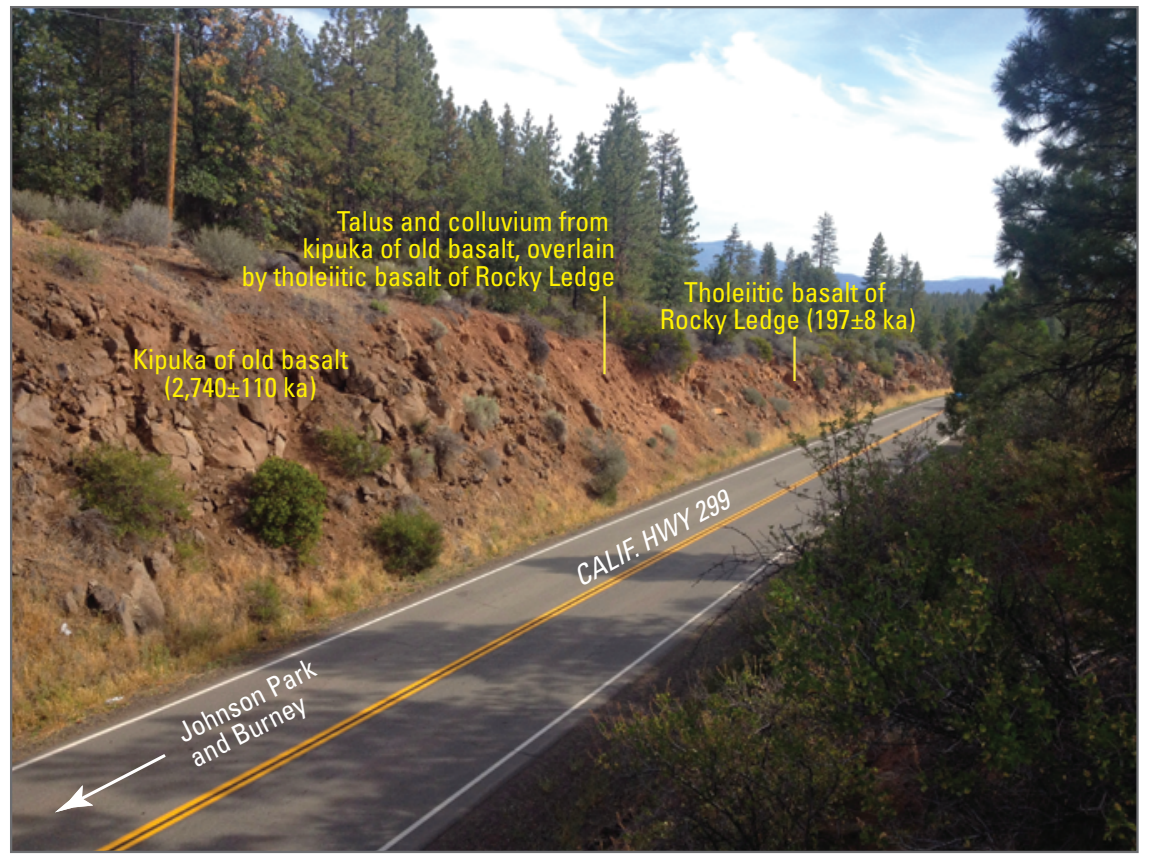




\section{References Cited}

Anderson, A.T., 1971, Alkali-rich, $\mathrm{SiO}_{2}$-deficient glasses in high-alumina olivine tholeiite, Hat Creek Valley, California: American Journal of Science, v. 271, p. 293-303.

Anderson, A.T., Friedman, J.O., Vander Wood, T., and Wyszynski, J., 1982, The fractional crystallization of plagioclase in the Hat Creek basalt; observations and theory: Journal of Geology, v. 90, p. 545-558.

Anderson, A.T., and Gottfried, D., 1971, Contrasting behavior of $\mathrm{P}, \mathrm{Ti}$, and $\mathrm{Nb}$ in a differentiated high-alumina olivine tholeiite and a calc-alkaline andesitic suite: Geological Society of America Bulletin, v. 82, p. 1929-1942.

Anderson, C.A., 1933, The Tuscan formation of northern California, with a discussion concerning the origin of volcanic breccias: University of California, Department of Geological Sciences Bulletin, v. 23, no. 7, p. 215-276.

Anderson, C.A., 1940, Hat Creek lava flow: American Journal of Science, v. 238, p. 477-492.

Bacon, C.R., 1983, Eruptive history of Mount Mazama and Crater Lake caldera, Cascade Range, U.S.A.: Journal of Volcanology and Geothermal Research, v. 18, p. 57-115.

Bacon, C.R., 1986, Magma inclusions in intermediate and silicic volcanic rocks: Journal of Geophysical Research, v. 91, p. 6091-6112.

Bacon, C.R., Bruggman, P.E., Christiansen, R.L., Clynne, M.A., Donnelly-Nolan, J.M., and Hildreth, W., 1997, Primitive magmas at five Cascade volcanic fields; melts from hot, heterogeneous sub-arc mantle: Canadian Mineralogist, v. 35, p. 397-423.

Berge, P.A., and Stauber, D.A., 1987, Seismic refraction study of upper crustal structure in the Lassen Peak area, northern California: Journal of Geophysical Research, v. 92, p. 1057110579.

Blake, M.C., Jr., Harwood, D.S., Helley, E.J., Irwin, W.P., Jayko, A.S., and Jones, D.L., 1999, Geologic map of the Red Bluff 30' x 60' quadrangle, California: U.S. Geological Survey Geologic Investigations Series Map I-2542, scale 1:100,000.

Blakely, R.J., Christiansen, R.L., Guffanti, M., Wells, R.E., Donnelly-Nolan, J.M., Muffler, L.J.P., Clynne, M.A., and Smith, J.G, 1997, Gravity anomalies, Quaternary vents, and Quaternary faults in the southern Cascade Range, Oregon and California-Implications for arc and backarc evolution: Journal of Geophysical Research, v. 102, p. 22513-22527.

Blakeslee, M.W., and Kattenhorn, S.A., 2013, Revised earthquake hazard of the Hat Creek fault, northern California; A case example of a normal fault dissecting variable-age basaltic lavas: Geosphere, v. 9, p. 1397-1409.
Borg, L.E., 1989, Petrogenesis of Magee Composite Volcano, northern California: Austin, University of Texas, M.A. thesis, $128 \mathrm{p}$.

Borg, L.E, 1995, The origin and evolution of magmas from the Lassen region of the southernmost Cascades: Austin, University of Texas, Ph.D. dissertation, $228 \mathrm{p}$.

Borg, L.E., Blichert-Toft, J., and Clynne, M.A., 2002, Ancient and modern subduction zone contributions to the mantle sources of lavas from the Lassen region of California inferred from Lu-Hf isotopic systematics: Journal of Petrology, v. 43, p. 705-723.

Borg, L.E., Brandon, A.D., Clynne, M.A., and Walker, R.J., 2000, Re-Os isotopic systematics of primitive lavas from the Lassen region of the Cascade arc, California: Earth and Planetary Science Letters, v. 177, p. 301-317.

Borg, L.E., and Clynne, M.A., 1998, The petrogenesis of felsic calc-alkaline magmas from the southernmost Cascades, California; Origin by partial melting of basaltic lower crust: Journal of Petrology, v. 39, p. 1197-1222.

Borg, L.E., Clynne, M.A., and Bullen, T.D., 1997, The variable role of slab-derived fluids in the generation of a suite of primitive calc-alkaline lavas from the southernmost Cascade Range: Canadian Mineralogist, v. 35, p. 425-452.

Brewer, W.H., 1930, Up and down California in 1860-1864; the journal of William H. Brewer (Farquhar, F.P., ed.): New Haven, Conn., Yale University Press, 601 p.

Bullen, T.D., and Clynne, M.A., 1990, Trace element and isotopic constraints on magmatic evolution at Lassen Volcanic Center, California: Journal of Geophysical Research, v. 95, p. 19671-19691.

Busby, C.J., 2013, Birth of a plate boundary at ca. 12 Ma in the ancestral Cascades arc, Walker Lane belt of California and Nevada: Geosphere, v. 9, p. 1147-1160.

Busby, C.J., Hagan, J.C., Putirka, K., Pluhar, C.J., Gans, P.B., Wagner, D.L., Rood, D., DeOreo, S.B., and Skilling, I., 2008, The ancestral Cascades arc; Cenozoic evolution of the central Sierra Nevada (California) and birth of a new plate boundary, in Wright, J.E., and Shervais, J.W., eds., Ophiolites, arcs, and batholiths-A tribute to Cliff Hopson: Geological Society of America Special Paper 438, p. 331-378.

Calvert, A.T., and Christiansen, R.L., 2011, Episodic growth of Mt. Shasta, CA, documented by argon geochronology [abs.]: American Geophysical Union, 2011 Fall Meeting, Abstract V13C-2613.

Christiansen, R.L., Clynne, M.A, and Muffler, L.J.P., 2002, Geologic map of the Lassen Peak, Chaos Crags, and Upper Hat Creek area, California: U.S. Geological Survey Geologic Investigations Series I-2723, 17 p., scale 1:24,000. 
Christiansen, R.L., and Miller, C.D., 1989, Mount Shasta and vicinity, in Muffler, L.J.P., Bacon, C.R., Christiansen, R.L., Clynne, M.A., Donnelly-Nolan, J.M., Miller, C.D., Sherrod, D.R., and Smith, J.G., South Cascades arc volcanism, California and southern Oregon, Excursion 12B of Chapin, C.E., and Zidek, J., eds., Field excursions to volcanic terranes in the western United States, Vol. II. Cascades and Intermountain West: New Mexico Bureau of Mines and Mineral Resources Memoir 47, p. 216-225.

Clynne, M.A., 1984, Stratigraphy and major element geochemistry of the Lassen Volcanic Center, California: U.S. Geological Survey Open-File Report 84-224, 168 p.

Clynne, M.A., 1990, Stratigraphic, lithologic and major element geochemical constraints on magmatic evolution at Lassen Volcanic Center, California: Journal of Geophysical Research, v. 95, p. 19651-19669.

Clynne, M.A., 1993, Geologic studies of the Lassen Volcanic Center, Cascade Range, California: Santa Cruz, University of California, Ph.D. dissertation, 404 p.

Clynne, M.A., 1999, Complex magma mixing origin for rocks erupted in 1915, Lassen Peak, California: Journal of Petrology, v. 40, p. 105-132.

Clynne, M.A., and Borg, L.E., 1997, Olivine and chromian spinel in primitive calc-alkaline and tholeiitic lavas from the southernmost Cascade Range-A reflection of relative fertility of the source: Canadian Mineralogist, v. 35, p.453-472.

Clynne, M.A., Champion, D.E., Trimble, D.A., Hendley, J.W., II, and Stauffer, P.H., 2000a, How old is "Cinder Cone"?Solving a mystery in Lassen Volcanic National Park, California: U.S. Geological Survey Fact Sheet 023-00, 4 p., available at http://pubs.usgs.gov/fs/2000/fs023-00/.

Clynne, M.A., Christiansen, R.L., Stauffer, P.H., Hendley, J.W., II, and Bleick, Heather, 2014, A sight "fearfully grand"Eruptions of Lassen Peak, California, 1914 to 1917: U.S. Geological Survey Fact Sheet 2014-3119, 4 p., available at http://pubs.usgs.gov/fs/2014/3119/.

Clynne, M.A., Christiansen, R.L., Miller C.D., Stauffer, P.H., and Hendley, J.W., II, 2000b, Volcano hazards of the Lassen Volcanic National Park area, California: U.S. Geological Survey Fact Sheet 022-00, 4 p., available at http://pubs.usgs. gov/fs/2000/fs022-00/.

Clynne, M.A., Christiansen, R.L., Muffler, L.J.P., and Ramsey, D., 2000c, Field trip guide_-Lassen Volcanic National Park and vicinity: Volcanism in National Parks, U.S. Geological Survey-National Park Service Workshop, Sept. 26-29, 2000, Redding and Lassen Volcanic National Park, California, 17 p.

Clynne, M.A., Christiansen, R.L., Trimble, D.A., and McGeehin, J.P., 2002, Radiocarbon dates from volcanic deposits of the Chaos Crags and Cinder Cone eruptive sequences and other deposits, Lassen Volcanic National Park and vicinity, California: U.S. Geological Survey Open-File Report 02-290, 21 p.
Clynne, M. A., Janik, C.J., and Muffler, L.J.P., 2003, Hot water in Lassen Volcanic National Park-Fumaroles, steaming ground, and boiling mudpots: U.S. Geological Survey Fact Sheet 101-02, 4 p. http://pubs.usgs.gov/fs/2002/fs101-02/.

Clynne, M.A., and Muffler, L.J.P., 1989, Lassen Volcanic National Park and vicinity, in Muffler, L.J.P., Bacon, C.R., Christiansen, R.L., Clynne, M.A., Donnelly-Nolan, J.M., Miller, C.D., Sherrod, D.R., and Smith, J.G., South Cascades arc volcanism, California and southern Oregon, Excursion 12B of Chapin, C.E., and J. Zidek, J., eds., Field excursions to volcanic terranes in the western United States, Vol. II. Cascades and Intermountain West: New Mexico Bureau of Mines and Mineral Resources Memoir 47, p. 183-194.

Clynne, M.A., and Muffler, L.J.P., 2010, Geologic map of Lassen Volcanic National Park and vicinity: U.S. Geological Survey, Scientific Investigations Map 2899, scale 1:50,000, available at http://pubs.usgs.gov/ $\operatorname{sim} / 2899 /$.

Clynne, M.A., Muffler, L.J.P., and Christiansen, R.L., 2004, Late Quaternary volcanic units in the Lassen region of the Cascade Range; Recurrence intervals and intercalation with glacial deposits [abs.]: International Association of Volcanology and Chemistry of the Earth's Interior, General Assembly, Pucón, Chile, Symposium 12b, abstract 12b_o_04.

Clynne, M.A., Muffler, L.J.P., Siems, D.F., Taggart, J.E., Jr., and Bruggman, P., 2008, Major and EDXRF trace element chemical analyses of volcanic rocks from Lassen Volcanic National Park and vicinity: U.S. Geological Survey OpenFile Report 2008-1091, 11 p. and .xls table, available at http://pubs.usgs.gov/of/2008/1091/.

Clynne, M.A., Robinson, J.E., Nathenson, M., and Muffler, L.J.P., 2012, Volcano hazards assessment for the Lassen region, northern California: U.S. Geological Survey Scientific Investigations Report 2012-5176-A, 47 p., 1 plate, scale 1:200,000, available at http://pubs.usgs.gov/ $\operatorname{sir} / 2012 / 5176 / \mathrm{a} /$.

Colman, S.M., and Pierce, K.L., 1992, Varied records of early Wisconsin alpine glaciation in the western United States derived from weathering-rind thicknesses, in Clark, P.U., and Lea, P.D., eds., The last interglacial-glacial transition in North America: Geological Society of America Special Paper 270, p. 269-278.

Crandell, D.R., 1972, Glaciation near Lassen Peak, northern California: U.S. Geological Survey Professional Paper 800-C, p. 179-188.

Crandell, D.R., 1989, Gigantic debris avalanche of Pleistocene age from ancestral Mount Shasta volcano, California, and debris-avalanche hazard zonation: U.S. Geological Survey Bulletin 1861, 32 p. 
Crandell, D.R., Miller, C.D., Glicken, H., Christiansen, R.L., and Newhall, C.G., 1984, Catastrophic debris avalanche from ancestral Mount Shasta volcano, California: Geology, v. 12 , p. $143-146$.

Crandell, D.R., Mullineaux, D.R., Sigafoos, R.S., and Rubin, M., 1974, Chaos Crags eruptions and rockfall-avalanches, Lassen Volcanic National Park, California: U.S. Geological Survey Journal of Research, v. 2, p. 49-59.

Crowley, J.K., Mars, J.C., John, D.A., Muffler, L.J.P., and Clynne, M.A., 2004, Hydrothermal mineral zoning within an eroded stratocone; Remote sensing spectral analysis of Brokeoff Volcano, California in King, P.L., Ramsey, M.S., and Swayze, G.A., eds., Infrared spectroscopy in geochemistry, exploration geochemistry, and remote sensing: London, Ontario, Mineralogical Association of Canada Short Course 33, p. 215-226.

Diller, J.S., 1891, A late volcanic eruption in northern California and its peculiar lava: U.S. Geological Survey Bulletin 79, $33 \mathrm{p}$.

Diller, J.S., 1895, Description of the Lassen Peak sheet, California: U.S. Geological Survey Geologic Atlas, Folio $15,14 \mathrm{p}$.

Eppler, D.B., Fink, J., and Fletcher, R., 1987, Rheologic properties and kinematics of emplacement of the Chaos Jumbles rockfall avalanche, Lassen Volcanic National Park, California: Journal of Geophysical Research, v. 92, p. 3623-3633.

Evernden, J.F., Savage, D.E., Curtis, G.H., and James, G.T., 1964, Potassium-argon dates and the Cenozoic mammalian chronology of North America: American Journal of Science, v. 262, p. 145-198.

Feeley, T.C., Clynne, M.A., Winer, G.S., and Grice, W.A., 2008a, Oxygen isotope geochemistry of the Lassen Volcanic Center, California; Resolving crustal and mantle contributions to continental arc magmatism: Journal of Petrology, v. 49, no. 5, p. 971-997.

Feeley, T.C., Wilson, L.F., and Underwood, S.J., 2008b, Distribution and compositions of magmatic inclusions in the Mount Helen dome, Lassen Volcanic National Park, California; Insights into magma chamber processes: Lithos, v. 106 , p. $173-189$.

Finch, R.H., 1930, Activity of a California volcano in 1786: The Volcano Letter, no. 308, p. 3.

Finch, R.H., 1937, A tree ring calendar for dating volcanic events at Cinder Cone, Lassen National Park, California: American Journal of Science, 5th Series, v. 33, p. 140-146.

Finch, R.H., and Anderson, C.A., 1930, The quartz basalt eruptions of Cinder Cone, Lassen Volcanic National Park, California: University of California, Department of Geological Sciences Bulletin, v. 19, p. 245-273.
Gill, J.B., 1981, Orogenic andesites and plate tectonics: New York, Springer-Verlag, $390 \mathrm{p}$.

Grose, T.L.T., Saucedo, G.J., and Wagner, D.L., 2013, Preliminary geologic map of the Susanville 30' x 60' quadrangle, California: California Division of Mines and Geology, available at ftp://ftp.consrv.ca.gov/pub/dmg/ rgmp/Prelim_geo_pdf/Susanville_100k_v2.0_Map.pdf; Accompanying pamphlet available at ftp://ftp.consrv. ca.gov/pub/dmg/rgmp/Prelim_geo_pdf/Susanville_100k v2.0_Pamphlet.pdf.

Guffanti, M., Clynne, M.A., and Muffler, L.J.P., 1996, Thermal and mass implications of magmatic evolution in the Lassen volcanic region, California, and minimum constraints on basalt influx to the lower crust: Journal of Geophysical Research, v. 101, p. 3003-3013.

Guffanti, M., Clynne, M.A., Smith, J.G., Muffler, L.J.P., and Bullen, T.D., 1990, Late Cenozoic volcanism, subduction and extension in the Lassen region of California, Southern Cascade Range: Journal of Geophysical Research, v. 95, p. $19453-19464$.

Guffanti, M., and Weaver, C.S., 1988, Distribution of late Cenozoic volcanic vents in the Cascade Range, volcanic arc segmentation and regional tectonic considerations: Journal of Geophysical Research, v. 93, p. 6513-6529.

Harkness, H.W., 1875, A recent volcano in Plumas County: California Academy of Sciences Proceedings, v. 5, p. $408-412$.

Hart, G.L., Johnson, C.M., Shirey, S.B., and Clynne, M.A., 2002, Osmium isotope constraints on lower crustal recycling and pluton preservation at Lassen Volcanic Center, CA: Earth and Planetary Science Letters, v. 199, p. 269-285.

Harwood, D.S., 1987, Late Cenozoic tectonism of the Sacramento Valley, California: U.S. Geological Survey Professional Paper 1359, $46 \mathrm{p}$.

Harwood, D.S., Helley, E.J., and Doukas, M.P., 1981, Geologic Map of the Chico Monocline and northeastern part of the Sacramento Valley, California: U.S. Geological Survey Map I-1238, scale 1:62,500.

Hausback, B.P., Muffler, L.J.P., and Clynne, M.A., 2011, Sutter Buttes - the lone volcano in California's Great Valley: U.S. Geological Survey Fact Sheet 2011-3024, 4 p. available at http://pubs.usgs.gov/fs/2011/3024/.

Heath, J.P., 1959, Dating Chaos Jumbles, an avalanche deposit in Lassen Volcanic National Park: American Journal of Science, v. 257, p. 537-538.

Heiken, G., 1978, Characteristics of tephra from Cinder Cone, Lassen Volcanic National Park: Bulletin Volcanologique, v. 41, p. $119-130$. 
Helley, E.J., and Harwood, D.S., 1985, Geologic map of the late Cenozoic deposits of the Sacramento Valley and northern Sierra Foothills, California: U.S. Geological Survey Miscellaneous Field Studies Map MF 1790, scale 1:62,500.

Helley, E.J., Harwood, D.S., Barker, J.A., and Griffin, E.A., 1981, Geologic map of the Battle Creek Fault Zone and adjacent parts of the northern Sacramento Valley, California: U.S. Geological Survey Miscellaneous Field Studies Map MF-1298, scale 1:62,500.

Hietanen, A., 1973, Geology of the Pulga and Bucks Lake Quadrangles, Butte and Plumas Counties, California: U.S. Geological Survey Professional Paper 731, 66 p.

Hildreth, W., 2007, Quaternary magmatism in the Cascadesgeologic perspectives: U.S. Geological Survey Professional Paper 1744, 125 p.

Ingebritsen, S.E., and Rojstaczer, S., 1983, The Sifford Peak Rings-a late Pliocene nested caldera complex [abs.]: Eos (American Geophysical Union Transactions), v. 64, p. 879.

Ingebritsen, S.E., and Sorey, M.L., 1985, A quantitative analysis of the Lassen hydrothermal system, north central California: Water Resources Research, v. 21, p. 853-868.

Janik, C.J., and McLaren, M.K., 2010, Seismicity and fluid geochemistry at Lassen Volcanic National Park, California; Evidence for two circulation cells in the hydrothermal system: Journal of Volcanology and Geothermal Research, v. 189 , p. $257-277$.

John, D.A., Breit, G.N., Lee, R.G., Dilles, J.H., Muffler, L.J.P., and Clynne, M.A., 2006, Fossil magmatic-hydrothermal systems in Pleistocene Brokeoff Volcano, Lassen Volcanic National Park [abs.]: American Geophysical Union, 2006 Fall Meeting, Abstract V53A-1745.

John, D.A., Rytuba, J.J., Breit, G.N., Clynne, M.A., and Muffler, L.J.P., 2005, Hydrothermal alteration in Maidu Volcano; A shallow fossil acid-sulfate magmatichydrothermal system in the Lassen Peak area, California, in Rhoden, H.N., Stininger, R.C., and Vikre, P.G., eds., Window to the World: Geological Society of Nevada Symposium 2005, p. 295-313.

Kane, P., 1982, Pleistocene glaciation, Lassen Volcanic National Park: California Geology, v. 35, p. 95-105.

KellerLynn, K., 2014, Lassen Volcanic National Park; geologic resources inventory report: National Park Service, Natural resource report NPS/NRSS/GRD/NRR—2014/755, 66 p., 2 sheets.

Klemetti, E.W., and Clynne, M.A., 2014, Localized rejuvenation of a crystal mush recorded in zircon temporal and compositional variation at the Lassen Volcanic Center, northern California: PLoS ONE v. 9, no. 12, doi:10.1371/ journal.pone.0113157, $22 \mathrm{p}$.
LaForge, R.C., and Hawkins, F.F., 1986, Seismotectonic study of northernmost California for Shasta, Keswick, Spring Creek Debris, Trinity, Lewiston, and Whiskeytown Dams: U.S. Bureau of Reclamation Seismotectonic Report No. 86-1, 132 p.

Lanphere, M.A, Champion, D.E., Clynne, M.A., Lowenstern, J.B., Sarna-Wojcicki, A.M., and Wooden, J.L., 2004, Age of the Rockland tephra, western U.S.A.: Quaternary Research, v. 62 , p. $94-104$.

Lanphere, M.A, Champion, D.E., Clynne, M.A., and Muffler, L.J.P., 1999, Revised age of the Rockland tephra, northern California-Implications for climate and stratigraphic reconstructions in the western United States: Geology, v. 27, p. 135-138.

Lydon, P.A., 1967, The origin of Tuscan Buttes and the volume of the Tuscan Formation in northern California: California Division of Mines and Geology Special Report 91, p.17-26.

Lydon, P.A., 1968, Geology and lahars of the Tuscan Formation, northern California, in Coats, R.R., Hay, R.L., and Anderson, C.A., eds., Studies in volcanology-A memoir in honor of Howel Williams: Geological Society of America Memoir 116, p. 441-475.

Macdonald, G.A., 1963, Geologic map of the Manzanita Lake quadrangle, California: U.S. Geological Survey Geologic Quadrangle Map GQ-248, scale 1:62,500.

Macdonald, G.A., 1964, Geologic map of the Prospect Peak quadrangle, California: U.S. Geological Survey Geologic Quadrangle Map GQ-345, scale 1:62,500.

Macdonald, G.A., 1965, Geologic map of the Harvey Mountain quadrangle, California: U.S. Geological Survey Geologic Quadrangle Map GQ-443, scale 1:62,500.

Meyer, C.E., Sarna-Wojcicki, A.M., Hillhouse, J.W., Woodward, M.J., Slate, J.L., and Sorg, D.H, 1991, Fissiontrack age (400,000 yr) of the Rockland tephra, based on inclusion of zircon grains lacking fossil fission tracks: Quaternary Research, v. 35, p. 367-382.

Meyer, C.E., Woodward, M.J., Sarna-Wojcicki, A.M., and Naeser, C.W., 1980, Zircon fission-track age of 0.45 million years on ash in the type section of the Merced Formation, west-central California: U.S. Geological Survey Open-File Report 83-193, 16 p.

Muffler, L.J.P., Champion, D.E., Calvert, A.T., and Clynne, M.A., 2012, Paleomagnetic, geochronologic, and petrologic data discriminate tholeiitic basalts of the northern Hat Creek Graben, northeastern California [abs]: American Geophysical Union, 2012 Fall Meeting, Abstract V33B-2868.

Muffler, L.J.P., Clynne, M.A., Calvert, A.T., and Champion, D.E. 2011, Diverse, discrete, mantle-derived batches of basalt erupted along a short normal fault zone; the Poison Lake chain, southernmost Cascades: Geological Society of America Bulletin, v. 123, p. 2177-2200. 
Muffler, L.J.P., Clynne, M.A., and Champion, D.E., 1994, Late Quaternary normal faulting of Hat Creek Basalt, northern California: Geological Society of America Bulletin, v. 106, p. 195-200.

Muffler, L.J.P., Jordan, R., and Cook, A.L., 1983, Maps showing thermal features and topography of Devils Kitchen and Bumpass Hell, Lassen Volcanic National Park, California: U.S. Geological Survey Miscellaneous Field Studies Map MF-1484, scale 1:2000.

Muffler, L.J.P., Nehring, N.L., Truesdell, A.H., Janik, C.J., Clynne, M.A., and Thompson, J.M., 1982, The Lassen geothermal system: Proceedings of Pacific Geothermal Conference, 1982, Part 2, p. 349-356.

Muffler, L.J.P., Robinson, J.E., Felger, T.J., Dutton, D.R., and Clynne, M.A., 2010, Database for the geologic map of Lassen Volcanic National Park and vicinity, California, in Clynne, M.A., and Muffler, L.J.P., Geologic map of Lassen Volcanic National Park and vicinity: U.S. Geological Survey Scientific Investigations Map 2899, scale 1:50,000 [CD-ROM].

Nathenson, M., Clynne, M.A, and Muffler, L.J.P., 2012, Eruption probabilities for the Lassen Volcanic Center and regional volcanism, northern California, and probabilities for large explosive eruptions in the Cascade Range: U.S. Geological Survey Scientific Investigations Report 2012-5176-B, 23 p., available at http://pubs.usgs.gov/ sir/2012/5176/b/.

Page, W. D., and Renne, P.R. $1994{ }^{40} \mathrm{Ar} /{ }^{39} \mathrm{Ar}$ dating of Quaternary basalt, western Modoc Plateau, northeastern California; Implications to Tectonics [abs.], in Lanphere, M.A., Dalrymple, G.B., and Turrin, B.D., eds.; Abstracts of the eighth international conference on geochronology, cosmochronology, and isotope geology: U.S. Geological Survey Circular 1107, $240 \mathrm{p}$.

Robinson, J.E., and Clynne, M.A., 2012, Lahar hazard zones for eruption-generated lahars in the Lassen Volcanic Center, California: U.S. Geological Survey Scientific Investigations Report 2012-5176-C, 13 p., available at http://pubs.usgs. gov/sir/2012/5176/c/.

Sarna-Wojcicki, A.M., Meyer, C.E., Bowman, H.R., Hall, N.T., Russell, P.C., Woodward, M.J., and Slate, J.L., 1985, Correlation of the Rockland Ash Bed, a 400,000-yearold stratigraphic marker in northern California and western Nevada, and implications for middle Pleistocene paleogeography of central California: Quaternary Geology, v. 23 , p. $236-257$.

Sheppard, P.R., Ort, M.H., Anderson, K.C., Clynne, M.A., and May, E.M., 2009, Multiple dendrochronological responses to the eruption of Cinder Cone, Lassen Volcanic National Park, California: Dendrochronologia, v. 27, p. 213-221.
Sherrod, D.R., and Smith, J.G., 1990, Quaternary extrusion rates of the Cascade Range, northwestern United States and southern British Columbia: Journal of Geophysical Research, v. 95, p. 19465-19474.

Sisson, T.W., and Layne, G.D., 1993, $\mathrm{H}_{2} \mathrm{O}$ in basaltic and basaltic andesite glass inclusions from four subductionrelated volcanoes: Earth and Planetary Science Letters, v. 117 , p. 619-635.

Sorey, M.L., and Ingebritsen, S.E., 1995, Heat and mass flow from thermal areas in and adjacent to Lassen Volcanic National Park, California, USA: International Geothermal Association, Proceedings of the World Geothermal Congress, Florence, Italy, 1995, v. 2, p. 751-755.

Strong, D.H., 1989, These happy grounds; a history of the Lassen Region: Red Bluff, Calif., Loomis Museum Association, fourth printing, $99 \mathrm{p}$.

Sun, A.S., and McDonough, W.F., 1989, Chemical and isotopic systematics of oceanic basalts; implications for mantle composition and processes; in Saunders, A.D., and Norry, M.J, eds., Magmatism in the Ocean Basins: Geological Society Special Publication No. 42, p. 313-345.

Tepley, F.J., III, Davidson, J.P., and Clynne, M.A., 1999, Magmatic interactions as recorded in plagioclase phenocrysts of Chaos Crags, Lassen Volcanic Center, California: Journal of Petrology, v. 40, p. 787-806.

Turrin, B.D., Christiansen, R.L., Clynne, M.A., Champion, D.E, Gerstel, W.J., Muffler, L.J.P., and Trimble, D.A., 1998, Age of Lassen Peak, California, and implications for the ages of late Pleistocene glaciations in the southern Cascade Range: Geological Society of America Bulletin, v. 110, p. 931-945.

Turrin, B.D., Muffler, L.J.P., Clynne, M.A., and Champion, D.E., 2007 , Robust $24 \pm 6 \mathrm{ka}{ }^{40} \mathrm{Ar} /{ }^{39} \mathrm{Ar}$ age of a lowpotassium tholeiitic basalt in the Lassen region of NE California: Quaternary Research, v. 68, p. 96-110.

Unruh, J.R., 1995, Late Cenozoic tectonics of the Greater Walker Lane Belt and implications for active deformation in the Lake Almanor Region, northeastern California, in Page, W.D., ed., Quaternary geology along the boundary between the Modoc Plateau, southern Cascade Mountains, and northern Sierra Nevada: Friends of the Pleistocene, 1995 Pacific Cell Field Trip, appendix B, 11 p.

Waldhauser, F. and D.P. Schaff, 2008, Large-scale relocation of two decades of Northern California seismicity using cross-correlation and double-difference methods, Journal of Geophysical Research, v. 113, B08311, doi:10.1029/ 2007JB005479 (version NCAeqDD.v201112.1).

Walker, E.L., 2008, Evolution of the Hat Creek fault system, northern California: Moscow, University of Idaho, M.S. thesis, $112 \mathrm{p}$. 
Walker, E.L., and Kattenhorn, S.A., 2008, Slip history and evolution of the Hat Creek Fault, Northern California [abs]: American Geophysical Union, 2008 Fall Meeting, Abstract T21B-1976.

Williams, H., 1932, Geology of the Lassen Volcanic National Park, California: University of California Department of Geological Sciences Bulletin, v. 21, p. 195-385.

Wills, C.J., 1991, Active faults north of Lassen Volcanic National Park, northern California: California Geology, v. 44 , p. 51-58.

Wilson, T.A., 1961, The geology near Mineral, California: Berkeley, University of California, M.S. thesis, 92 p. 


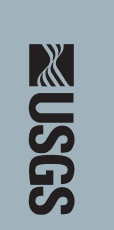

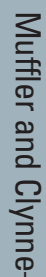

용

응.

꿈

혹.

흠ำ

密

$\stackrel{\text { จ }}{3}$

홍

ลे.

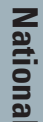

핮

를

ํ.ᅩㄹ.

을

을.

1

?.

离:

इ

尽.

훙.

क

융

जั

ISBN 978-1-41.13-3926-2 